


\section{Rekentool voor het bepalen van de effecten van voer- en management- maatregelen op de ammoniakemissie bij varkens: ontwikkeling en validatie}

Andre Aarnink ${ }^{1}$, Loes van de Pas ${ }^{2}$, Carola van der Peet-Schwering ${ }^{1}$, Annemieke Hol $^{1}$, Gisabeth Binnendijk ${ }^{1}$, Le Dinh Phung ${ }^{3}$, Sasha Hafner ${ }^{4}$, Nico Ogink ${ }^{1}$

\footnotetext{
${ }^{1}$ Wageningen Livestock Research

2 Varkens Innovatiecentrum Sterksel

${ }^{3}$ Faculty of Animal Sciences, Hue University of Agriculture and Forestry, Vietnam

${ }^{4}$ Department of Chemical Engineering, University of Southern Denmark
} 
Aarnink, A.J.A., Van de Pas, P.A., Van der Peet-Schwering, C.M.C., Hol, A., Binnendijk, G.P., Le Dinh, P., Hafner, S.D., Ogink, N.W.M., 2018. Rekentool voor het bepalen van de effecten van voer-en managementmaatregelen op de ammoniakemissie bij varkens: ontwikkeling en validatie. Wageningen University \& Research, Livestock Research Rapport 1086.

Samenvatting NL: Er is een rekenmodel ontwikkeld om het effect van huisvestings-, voer- en management-maatregelen op de ammoniakemissie te berekenen in stallen voor vleesvarkens, gespeende biggen en drachtige zeugen. Op VIC Sterksel zijn metingen gedaan om het model verder te ontwikkelen en te valideren.

Trefwoorden: rekenmodel, ammoniakemissie, voermaatregelen, vleesvarkens, gespeende biggen, zeugen

Summary UK: A calculation model was developed to determine the effect of housing, dietary and management measures on the ammonia emission from houses for growing-finishing pigs, weaned piglets and pregnant sows. On Pig Innovation Centre Sterksel measurements were done for further development and validation of the model.

Keywords: calculation model, ammonia emission, feeding measures, growing-finishing pigs, weaned piglets, sows

Dit rapport is gratis te downloaden op https://doi.org/10.18174/442139 of op

www.wur.nl/livestock-research (onder Wageningen Livestock Research publicaties).

(c) 2018 Wageningen Livestock Research

Postbus 338, 6700 AH Wageningen, T 03174839 53, E info.livestockresearch@wur.nl, www.wur.nl/livestock-research. Wageningen Livestock Research is onderdeel van Wageningen University \& Research.

Wageningen Livestock Research aanvaardt geen aansprakelijkheid voor eventuele schade voortvloeiend uit het gebruik van de resultaten van dit onderzoek of de toepassing van de adviezen.

Alle rechten voorbehouden. Niets uit deze uitgave mag worden vermenigvuldigd en/of openbaar gemaakt worden door middel van druk, fotokopie, microfilm of op welke wijze dan ook zonder voorafgaande toestemming van de uitgever of auteur.

Wageningen Livestock Research is NEN-EN-ISO 9001:2015 gecertificeerd.

Op al onze onderzoeksopdrachten zijn de Algemene Voorwaarden van de Animal Sciences Group van toepassing. Deze zijn gedeponeerd bij de Arrondissementsrechtbank Zwolle. 


\section{Inhoud}

$\begin{array}{lr}\text { Woord vooraf } & 5\end{array}$

$\begin{array}{lr}\text { Samenvatting } & 7\end{array}$

$\begin{array}{lr}\text { Summary } & 9\end{array}$

$\begin{array}{llr}1 & \text { Inleiding } & 11\end{array}$

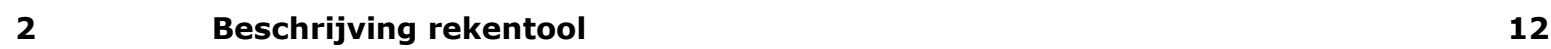

$2.1 \quad$ Globale beschrijving $\quad 12$

2.2 Gewichtsverloop vleesvarkens en voer- en wateropname 15

2.3 Hoeveelheid en samenstelling van de uitgescheiden mest 16

2.4 Hoeveelheid en samenstelling van de mengmest in de mestkelder 22

$\begin{array}{lll}2.5 & \text { Ammoniakemissie } & 24\end{array}$

2.6 Gespeende biggen $\quad 27$

$\begin{array}{lll}2.7 & \text { Drachtige zeugen } & 28\end{array}$

3

Materiaal en methode $\quad 30$

$\begin{array}{lll}3.1 & \text { Proeflocatie en proefomvang } & 30\end{array}$

$\begin{array}{lll}3.2 & \text { Proefbehandelingen } & 30\end{array}$

$\begin{array}{lll}3.3 & \text { Proefopzet en proefindeling } & 31\end{array}$

$\begin{array}{lll}3.4 & \text { Huisvesting en klimaat } & 31\end{array}$

$\begin{array}{lll}3.5 & \text { Voer- en drinkwaterverstrekking } & 35\end{array}$

3.6 Afleverstrategie $\quad 36$

3.7 Metingen en waarnemingen $\quad 37$

3.8 Gegevensverwerking en statistische analyse 39

$4 \quad$ Resultaten en discussie $\quad 41$

$\begin{array}{lll}4.1 & \text { Vleesvarkens } & 41\end{array}$

4.1.1 Technische resultaten van opleg tot afleveren (alle hokken) 41

4.1.2 Technische resultaten per gewichtstraject $\quad 41$

$\begin{array}{ll}4.1 .3 \text { Slachtkwaliteit } & 43\end{array}$

4.1.4 Uitval en veterinaire behandelingen $\quad 44$

4.1.5 Mestproductie en -samenstelling 45

4.1.6 Bevuilde oppervlakken, temperatuur, luchtsnelheid, ventilatie, verdamping

en ammoniakemissie $\quad 47$

$\begin{array}{lll}4.2 & \text { Gespeende biggen } & 49\end{array}$

4.2.1 Technische resultaten hele opfokperiode (alle hokken) 49

4.2.2 Technische resultaten per gewichtstraject $\quad 49$

4.2.3 Uitval en veterinaire behandelingen $\quad 50$

4.2.4 Mestproductie en -samenstelling 51

4.2.5 Bevuilde oppervlakken, temperatuur, luchtsnelheid, ventilatie, verdamping en ammoniakemissie $\quad 53$

4.3 Drachtige zeugen $\quad 54$

4.3.1 Voeropname en diergewicht $\quad 54$

4.3.2 Mestproductie en -samenstelling $\quad 55$

4.3.3 Bevuilde oppervlakken, temperatuur, luchtsnelheid, ventilatie, verdamping en ammoniakemissie 
5.1 Extra inputgegevens voor de modelvalidatie 59

5.2 Gewichtsverloop vleesvarkens en voer en wateropname 59

5.3 Hoeveelheid en samenstelling van de mengmest in de kelder bij vleesvarkens 61

5.4 Samenstelling van de urineplassen op de vloer bij vleesvarkens 65

5.5 Ammoniakemissie bij vleesvarkens $\quad 66$

5.6 Gemeten en berekende behandelingseffecten bij vleesvarkens 70

$\begin{array}{lll}5.7 & \text { Modelvalidatie biggen } & 72\end{array}$

5.8 Gemeten en berekende behandelingseffecten bij biggen $\quad 77$

$\begin{array}{lll}5.9 & \text { Validatie model zeugen } & 78\end{array}$

5.10 Gemeten en berekende behandelingseffecten bij zeugen $\quad 81$

5.11 Aanvullende analyse gemeten waarden $\quad 82$

6 $\begin{array}{lr}\text { Algemene discussie } & 85\end{array}$

$\begin{array}{lll}6.1 & \text { Inputgegevens } & 85\end{array}$

$\begin{array}{lll}6.2 & \text { Eiwitaanzet } & 86\end{array}$

$\begin{array}{lll}6.3 & \text { Waterverdamping } & 87\end{array}$

$\begin{array}{lll}6.4 & \mathrm{pH} \text { van urine en mengmest } & 87\end{array}$

$\begin{array}{lll}6.5 & \text { Emitterende oppervlakken } & 88\end{array}$

$\begin{array}{lll}6.6 & \text { Temperatuur en luchtsnelheid } & 89\end{array}$

6.7 Analyse van metingen en behandelingseffecten $\quad 89$

$\begin{array}{lll}6.8 & \text { Productieresultaten } & 90\end{array}$

6.9 Betrouwbaarheid rekentool $\quad 91$

6.10 Stand van zaken rekentool 92

$\begin{array}{llr}7 & \text { Conclusies } & 93\end{array}$

$\begin{array}{llr}8 & \text { Aanbevelingen } & 94\end{array}$

$\begin{array}{lr}\text { Literatuur } & 95\end{array}$

$\begin{array}{lr}\text { Bijlagen } & 97\end{array}$ 


\section{Woord vooraf}

Voer- en managementmaatregelen kunnen naast technische en huisvestingsmaatregelen een belangrijke bijdrage leveren aan de reductie van de ammoniakemissie uit varkensstallen, en worden in de regelgeving ingezet als ondersteuning van de Programmatische Aanpak Stikstof (PAS). Deze maatregelen kennen een heel scala aan varianten en niveaus waarop ze kunnen worden toegepast. Het is vrijwel ondoenlijk om het effect van al deze varianten te bemeten. Daarom heeft het Ministerie van Landbouw, Natuur en Voedselkwaliteit (bij de start van het onderzoek vallend onder het Ministerie van Economische Zaken) Wageningen Livestock Research opdracht gegeven om deze effecten modelmatig te benaderen.

$\mathrm{Er}$ is in de afgelopen decennia veel kennis verkregen over de processen en factoren die de emissie van ammoniak bepalen. Vanuit deze kennis is in dit onderzoek een rekentool ontwikkeld waarmee de emissie van ammoniak bij verschillende voer- en managementstrategieën kan worden bepaald. Ook het effect van aanpassingen in stalontwerp en stalklimaat kunnen worden doorgerekend. We moeten ons realiseren dat er continu nieuwe kennis en inzichten beschikbaar komt waarmee het model kan worden verbeterd. In dit onderzoek is het model, voor een aantal voermaatregelen, gevalideerd bij vleesvarkens, gespeende biggen en guste en drachtige zeugen. Verdere validatie op praktijkbedrijven met andere maatregelen is wenselijk.

We willen de medewerkers van VIC Sterksel van harte bedanken voor hun inzet bij de validatie van dit model, evenals het Ministerie van Landbouw, Natuur en Voedselkwaliteit voor de financiering van dit onderzoek. Als onderzoekers zijn we er van overtuigd dat deze rekentool een belangrijke bijdrage kan leveren aan de implementatie van kostenefficiënte methoden om de ammoniakemissie uit de varkenshouderij te reduceren.

Mede namens de co-auteurs

André Aarnink

Projectleider 


\section{Samenvatting}

In het kader van de Programmatische Aanpak Stikstof (PAS) is er behoefte aan de ontwikkeling en implementatie van voer- en managementmaatregelen en aanvullende technische maatregelen om de uitstoot van ammoniak uit varkensstallen te verminderen. Deze maatregelen kunnen een heel scala aan maatregelen omvatten. Het zou veel tijd en geld kosten om van al deze maatregelen en combinaties van maatregelen het effect op de ammoniakemissie te meten. Daarom heeft het Ministerie van Economische Zaken aan Wageningen Livestock Research de opdracht gegeven om een rekentool te ontwikkelen waarmee de effecten van dit type maatregelen ingeschat kunnen worden.

Het doel van dit project is het ontwikkelen en valideren van een rekentool om de effecten van huisvestings- en voer- en managementmaatregelen op de ammoniakemissie bij vleesvarkens, gespeende biggen en zeugen te kunnen berekenen.

De rekentool gaat uit van inputgegevens die relatief eenvoudig verkregen kunnen worden, namelijk de duur van de productieperiode, het begin- en eindgewicht van de varkens, de totale voer- en wateropname over de gehele productieperiode en de voersamenstelling (inclusief de verteringscoëfficiënten van de belangrijkste componenten). De rekentool berekent gemiddelde ammoniakemissies per dag en doet dit gedurende de gehele productieperiode. In eerste instantie zijn rekenregels opgesteld voor het kunnen berekenen van het gewichtsverloop van de dieren en van de voer- en wateropname. Vervolgens zijn rekenregels opgesteld om op basis hiervan de hoeveelheid en de samenstelling van de uitgescheiden mest (urine, feces en mengmest) te berekenen. Op de vloer en in de mestkelder vinden nog allerlei processen plaats die de samenstelling van urineplassen en mengmest doen veranderen, hiervoor zijn ook rekenregels opgesteld. Uit het voorgaande kan vervolgens de ammoniakemissie per $\mathrm{m}^{2}$ emitterend oppervlak worden berekend. Hierbij worden verschillende emitterende oppervlakken onderscheiden, o.a. emitterend vloer- en emitterend kelderoppervlak. Door vervolgens deze bronsterkten (emissies per $\mathrm{m}^{2}$ ) te vermenigvuldigen met de grootte van de emitterende oppervlakken kan de totale ammoniakemissie en de ammoniakemissie van elke bron afzonderlijk worden bepaald. Voor vleesvarkens, biggen en zeugen is de rekentool zeer vergelijkbaar, slechts enkele rekenregels zijn specifiek voor de betreffende diercategorie.

Om de rekentool te kunnen valideren is op VIC Sterksel een onderzoek uitgevoerd waarin het effect van bepaalde voermaatregelen op de productieresultaten van de varkens en op de urine- en mestsamenstelling en op de ammoniakemissie is gemeten bij vleesvarkens, gespeende biggen en drachtige zeugen. Bij vleesvarkens zijn 4 voerbehandelingen (controle, verlaagd eiwit, verzurend voer, combi verlaagd eiwit en verzurend) onderzocht in 4 afdelingen gedurende één productieronde. Dezelfde voerbehandelingen zijn onderzocht bij gespeende biggen in 4 afdelingen gedurende 2 ronden. Bij drachtige zeugen zijn 2 voerbehandelingen (controle en combi-voer) onderzocht. De onderzochte afdelingen op VIC Sterksel zijn zeer vergelijkbaar met afdelingen in praktijkstallen. In voornoemde onderzoeksafdelingen is een uitvoerig meetprogramma uitgevoerd. Er zijn continue metingen gedaan van ammoniakconcentraties, ventilatiedebieten en afdelingstemperaturen en discontinue metingen van mestproductie, mestsamenstelling, hokbevuiling (met urine) en temperaturen van en luchtsnelheden boven de emitterende oppervlakken. Verder zijn de voeropnames wekelijks bijgehouden en de wateropname dagelijks. Tevens zijn (een aantal) dieren gewogen bij opleg en afvoer uit de afdelingen en bij elke voerovergang. Op deze manier konden de productieresultaten worden berekend. Tevens werden de veterinaire behandelingen geregistreerd.

De belangrijkste conclusies uit het onderzoek zijn:

- Gemiddeld berekende totale absolute ammoniakemissiewaarden op jaarbasis komen goed overeen met gemeten waarden.

- Gemiddeld berekende ammoniakemissies vanaf de vloer komen bij vleesvarkens en, in iets mindere mate, bij zeugen goed overeen met de gemeten waarden. Voor biggen werd de vloeremissie te laag ingeschat in de tweede helft van de opfokperiode. 
- Het (relatieve) effect van de eiwitbehandeling (verlaagd eiwitgehalte in het voer) kon goed worden ingeschat met de rekentool bij vleesvarkens en biggen. Dit gold voor zowel het effect op de totale emissie als het effect op de vloeremissie. Het effect bij zeugen kon niet goed worden ingeschat. Dit werd waarschijnlijk veroorzaakt door gebruik van verkeerde inputgegevens (te lage

verteringscoëfficiënten van het voer). De gemeten effecten van het eiwitgehalte zijn iets hoger dan gemeten in eerdere onderzoeken.

- Het (relatieve) effect van het verzurende voer kan nog niet goed worden voorspeld met het model. Dit wordt voor een deel veroorzaakt door het feit dat het effect van benzoëzuur in het voer op de $\mathrm{pH}$ van de mengmest nog niet is opgenomen in het model. Voor een ander deel wordt dit veroorzaakt door het feit dat de effecten van verzurend voer op de $\mathrm{pH}$ van urine en mengmest op dit moment nog heel moeilijk te voorspellen zijn, vooral omdat een groot aantal factoren hier invloed op kunnen hebben. Met name het carbonaatgehalte van urine en mengmest is moeilijk te voorspellen.

- Het gemeten effect van benzoëzuurtoevoeging (1\%) aan het voer op de ammoniakemissie bij vleesvarkens komt goed overeen met eerder gevonden effecten. Bij toevoeging van benzoëzuur $(0,5 \%)$ aan biggenvoer werd geen effect op de ammoniakemissie gevonden.

- Er lijkt vrijwel geen effect te zijn van het vervangen van Ca-carbonaat door Ca-formiaat aan het voer op de ammoniakemissie.

- Een verlaagd eiwitgehalte in het voer gaf een hogere groei bij vleesvarkens ten opzichte van het controlevoer vooral als gevolg van een hogere voeropname. Het verzurende voer en het combivoer zaten qua groei en voeropname tussen het controlevoer en het verlaagd eiwitvoer in.

- Bij biggen lijkt het verzurende voer een negatieve invloed te hebben op de gezondheid van de dieren. Biggen die het verzurende voer kregen verstrekt moesten significant vaker worden behandeld voor beenwerkproblemen.

- De rekentool kan gebruikt worden om effecten van huisvestings- en voer- en management maatregelen op de ammoniakemissie in te schatten. Voor het bepalen van effecten van voermaatregelen op de $\mathrm{pH}$ van de mest is het model nog onvoldoende geschikt. Als tussenoplossing hiervoor zouden de $\mathrm{pH}^{\prime}$ s van urine en mest gemeten kunnen worden en als input worden gebruikt in het model voor berekening van de ammoniakemissie.

De belangrijkste aanbevelingen zijn:

- De rekentool biedt een goede basis voor het doorrekenen van effecten van (gecombineerde) voer, management- en huisvestingsmaatregelen op de ammoniakemissie uit stallen voor vleesvarkens, gespeende biggen en drachtige zeugen.

- $\quad$ Een aantal parameters/variabelen in de rekentool zijn met behulp van de kleinste kwadraten methode of regressieanalyse op verzamelde data in dit onderzoek verkregen. Dezelfde dataset is ook gebruikt voor validatie van de rekentool. Het is aan te bevelen om de rekentool verder te valideren met onafhankelijke datasets.

- De huidige rekentool is op dit moment vooral bruikbaar in onderzoek. Om deze tool bruikbaar te maken voor andere doelgroepen (overheid, varkenshouders, voorlichters, toeleverend bedrijfsleven) zal de interface, met in- en output, vergaand versimpeld moeten worden.

- De rekentool is goed te gebruiken voor situaties die moeilijk te bemeten zijn, zoals bijvoorbeeld een uitloop voor varkens. Lokaal gemeten variabelen kunnen dan gebruikt worden als input voor het model om de ammoniakemissie in te schatten.

- Het is belangrijk om de rekentool te laten beoordelen door vakgenoten. Dit zou kunnen door de rekentool in één of meerdere artikelen te publiceren in een wetenschappelijke tijdschrift. 


\section{Summary}

Under the Programmatic Approach Nitrogen (PAS) there is a need for the development and implementation of feed and management measures and additional technical measures to reduce the emission of ammonia from pig farms. These measures can include a wide range of measures. It would take a lot of time and money to measure the impact of all these measures and combinations of measures on the ammonia emission. Therefore, the Ministry of Economic Affairs has requested Wageningen Livestock Research to develop a calculation tool to assess the effects of this type of measures.

The objective of this project is to develop and validate a calculation tool to calculate the effects of housing and feed and management measures on the ammonia emission in growing-finishing pigs, weaned piglets and sows.

The calculation tool is based on input data that can be obtained relatively easily, namely the duration of the production period, the initial and final weight of the pigs, the total feed and water consumption over the entire production period and the feed composition (including the digestibility coefficients of the main components of the diet). The calculation tool calculates mean ammonia emissions per day and does this throughout the entire production period. At first, calculation rules have been developed for calculating the weight of the animals and the feed and water intake. Subsequently, calculation rules have been developed to calculate the amount and composition of the excreted manure (urine, feces and mixed manure). On the floor and in the manure there are also various processes that change the composition of urine puddles and mixed manure, for these processes calculation rules were developed, as well. Finally, from this, the ammonia emission per $\mathrm{m}^{2}$ of emitting surface area is calculated. Different emitting surfaces can be distinguished, including the emitting floor area and the emitting area of the manure surface. By multiplying these source strengths (emissions per $\mathrm{m}^{2}$ ) with the size of the emitting areas, the total ammonia emission and the ammonia emissions of each source can be estimated. For fattening pigs, piglets and sows the calculation rules are very similar, only a few formula are specific for the particular animal category.

In order to be able to validate the calculation tool, an investigation was conducted at VIC Sterksel in which the effect of certain feed measures on pig production and on the urine and manure composition and on the ammonia emission have been measured in growing-finishing pigs, weaned piglets and pregnant sows. In growing-finishing pigs, 4 dietary treatments (control, reduced protein, acidifying feed, combi-diet with reduced protein and acidifying) were studied in 4 compartments during one production round. The same dietary treatments were investigated for weaned piglets in 4 compartments during 2 rounds. In pregnant sows, 2 dietary treatments (control and combi-diet) have been investigated. The investigated compartments at VIC Sterksel are very similar to pig houses used in commercial farming. A comprehensive measurement program was carried out in the aforementioned research compartments. Continuous measurements were done of ammonia concentrations, ventilation rates and room temperatures and discontinuous measurements were done of manure production, manure composition, pen fouling (with urine) and temperatures of and air velocities above the emitting surfaces. Furthermore, the amount of consumed feed was recorded weekly and the water intake daily. Also, (a number of) animals were weighed during loading and unloading from the compartments and at each feed change. In this way, the production results could be calculated. Veterinary treatments were also recorded.

The main conclusions of this study are:

- Average calculated total absolute ammonia emission values on a yearly basis correspond well with measured values.

- Average calculated ammonia emissions from the floor in growing-finishing pigs and, to a lesser degree, also in sows closely match the measured values. For piglets, the floor emissions were estimated too low in the second half of the growing period.

- The (relative) effect of the protein treatment (reduced protein content in the feed) could be well estimated with the calculation model for growing-finishing pigs and weaned piglets. This was valid for both the effect on the total emission as for the effect on the floor emission. This effect could not be estimated well for sows. This was probably caused by the use of incorrect input data (too low 
digestion coefficients of the diets). The measured protein effects are slightly higher than measured in previous studies.

- The (relative) effect of the acidifying feed cannot be accurately predicted with the model. This is partly due to the fact that the effect of benzoic acid in the diet on the $\mathrm{pH}$ of the manure is not yet included in the model. For another part, this is due to the fact that the effects of acidifying feed on the $\mathrm{pH}$ of urine and manure are currently very difficult to predict, especially because a large number of factors are affecting the $\mathrm{pH}$. Especially, the carbonate content of urine and manure is hard to predict.

- The measured effect of benzoic acid addition (1\%) on the ammonia emission in growing-finishing pigs corresponds well with measured effects in former studies. With the addition of benzoic acid $(0.5 \%)$ to piglet feed no measured effect on ammonia emission was found.

- There seems to be almost no effect of replacing Ca-carbonate with Ca-formate in the diet on the ammonia emission.

- The decreased protein diet gave a higher growth rate in growing-finishing pigs when compared with the control diet, mainly due to a higher feed intake; the growth rate and feed intake of the acidifying diet and the combi-diet were in between.

- In piglets, the acidifying diet seems to have a negative impact on animal health. Weaned piglets that received the acidifying diet had to be treated significantly more frequently for leg problems.

- The calculation tool can be used to estimate effects of housing and feed and management measures on the ammonia emission. To determine the effects of feed measures on the manure $\mathrm{pH}$, the model is still insufficiently suitable. As an intermediate solution, the $\mathrm{pH}$ of urine and manure can be measured and used as input in the ammonia emission calculation model.

The most important recommendations are:

- The calculation tool provides a good basis for calculating the effects of (combined) feed, management and housing measures on the ammonia emission from houses for fattening pigs, weaned piglets and pregnant sows.

- A number of parameters / variables in the calculation tool were obtained by using the least squares method or regression analysis on collected data in this study. The same dataset is also used for validation of the calculation tool. It is recommended to further validate the calculation tool with independent data sets.

- The calculation tool is currently very useful in research. In order to make this tool usable for other target groups (government, pig farmers, information officers, supplying industry), the interface, with input and output, will have to be extensively simplified.

- The calculation tool is very suitable for situations that are difficult to measure, such as for example an outside yard for pigs. Locally measured variables can then be used as input for the model to estimate the ammonia emission.

- It is important to have the calculation tool reviewed by peers. This could be done by publishing the calculation tool in one or more articles in a scientific journal. 


\section{$1 \quad$ Inleiding}

In het kader van de Programmatische Aanpak Stikstof (PAS) is er behoefte aan de ontwikkeling en implementatie van voer- en managementmaatregelen en aanvullende technische maatregelen om de uitstoot van ammoniak te verminderen (hier verder PAS-maatregelen genoemd). PAS-maatregelen moeten leiden tot minder ammoniakemissie uit de veehouderij via emissiearm voer en emissie reducerend management. Voer- en managementmaatregelen kunnen een hele range aan maatregelen omvatten (zie o.a. de rapporten (Aarnink et al., 2012; Aarnink et al., 2010). Het gaat hierbij om verschillende typen maatregelen en om verschillende niveaus binnen een bepaald type maatregel, b.v. eiwitgehalte van het voer of gehalte aan verzurende Ca-zouten. Het zou veel tijd en geld kosten om van al deze maatregelen en combinaties van maatregelen het effect op de ammoniakemissie te meten. Een kostenbesparend alternatief voor het meten is gebruik te maken van een rekentool waarmee de effecten van dit type maatregelen ingeschat kunnen worden.

Het doel van dit project is het ontwikkelen en valideren van een rekentool om de effecten van huisvestings- en voer- en managementmaatregelen op de ammoniakemissie bij vleesvarkens, gespeende biggen en zeugen te kunnen berekenen. Het rekenmodel bestaat uit drie stappen:

1. Effect bepalen van voer- en managementmaatregelen op de urine- en mestsamenstelling. Hierbij zijn het ammoniumgehalte en de $\mathrm{pH}$ van belang.

2. Effect bepalen van het ammoniumgehalte en de $\mathrm{pH}$ van urine en mest en de omgevingsfactoren (temperatuur en luchtsnelheid) op de ammoniakemissie per $\mathrm{m}^{2}$ bevuild oppervlak.

3. Bepalen van de ammoniakemissie op afdelings-/stalniveau door de ammoniakemissies per $\mathrm{m}^{2}$ bevuild oppervlak te vermenigvuldigen met de grootte van de emitterende oppervlakken.

Om de rekentool te kunnen valideren is op VIC Sterksel een onderzoek uitgevoerd waarin het effect van voermaatregelen op de urine- en mestsamenstelling en de ammoniakemissie is gemeten bij vleesvarkens, gespeende biggen en drachtige zeugen. Naast validatiegegevens voor het rekenmodel levert dit onderzoek ook belangrijke informatie over:

- De ontwikkeling van nieuwe (meet)methoden om de ammoniakemissie te bepalen. Nieuwe methoden zijn vooral van belang voor bepaling van ammoniakemissies uit open stallen of vanaf een uitloop. Een mogelijke methode is de combinatie van lokale metingen en modelmatige berekeningen zoals beschreven in Aarnink et al. (2015). Uit voornoemd onderzoek is gebleken dat zo'n methode duidelijk perspectief biedt om toe te passen in open stallen waar moeilijk directe emissiemetingen kunnen worden gedaan.

- Het effect van de voermaatregelen. Met name het effect van toevoeging van benzoëzuur i.c.m. vervanging van Ca-carbonaat door Ca-formiaat is nog niet onderzocht. Ook het gecombineerde effect van eiwitverlaging en de verzurende componenten benzoëzuur en Ca-formiaat is nog niet onderzocht.

In hoofdstuk 2 worden de verschillende rekenregels in de rekentool beschreven, te beginnen bij vleesvarkens. Voor gespeende biggen en zeugen wordt in dit hoofdstuk vervolgens aangegeven wat de verschillen zijn met het model voor vleesvarkens. In hoofdstuk 3 wordt materiaal en methode van het onderzoek op VIC Sterksel beschreven en in hoofdstuk 4 de resultaten van dit onderzoek (effecten van de voermaatregelen op de productieresultaten, de urine- en mestsamenstelling en de ammoniakemissie). In hoofdstuk 5 worden de resultaten van de modelvalidatie weergegeven en bediscussieerd. In hoofdstuk 6 is een algemene discussie van de resultaten opgenomen en in hoofdstuk 7 worden de belangrijkste conclusies van dit rapport gegeven. 


\section{$2 \quad$ Beschrijving rekentool}

\subsection{Globale beschrijving}

Om het effect van voermaatregelen op de ammoniakemissie te kunnen bepalen moet de rekentool gericht zijn op het doorrekenen van de gehele keten van voeropname door het varken, het metabolisme in het varken, de uitscheiding van urine en feces door het varken en de beschrijving van de fysisch/chemische/biologische processen die plaatsvinden in de urineplassen op de vloer en de mengmest in de mestkelder. In figuur 1 wordt schematisch de opbouw van de rekentool weergegeven. De rekentool start met de berekening van de dagelijkse voer- en wateropname gedurende de gehele productieperiode. Op basis van het productiestadium van het varken, de opname van metaboliseerbare energie en de (berekende) groeicurve wordt de $\mathrm{N}$-aanzet in het dier berekend. Met behulp van de verteringscoëfficiënten van het voer (met name eiwit) en de N-aanzet wordt de uitgescheiden hoeveelheid $\mathrm{N}$ in de feces en urine berekend. Doordat er tevens een waterbalans wordt gemaakt, kunnen tevens de concentraties worden berekend. Een deel van de urine blijft liggen op de vloer en door omzetting van ureum in $\mathrm{NH} 4-\mathrm{N}$ kan een deel van deze $\mathrm{N}$ in de urine vervluchtigen als $\mathrm{NH}_{3}$. De overige urine komt samen met de feces in de mestkelder terecht. In de mengmest wordt ureum ook ongezet naar $\mathrm{NH} 4-\mathrm{N}$ en een deel hiervan vervluchtigt als $\mathrm{NH}_{3}$. In bijlage 1 is een meer gedetailleerd schema opgenomen met daarin de belangrijkste input, output en te berekenen modelvariabelen. Het schema is gelijk voor vleesvarkens, gespeende biggen en zeugen. Ook de rekenregels zijn voor een belangrijk deel gelijk voor alle categorieën varkens.

Belangrijk bij de ontwikkeling van de rekentool was te bepalen welke informatie vanuit de varkenshouderij redelijk eenvoudig beschikbaar is of kan zijn om als input te dienen voor het model. Bij deze analyse zijn we uitgekomen op de volgende inputvariabelen voor een groep varkens op afdelingsniveau:

- Duur productieperiode

- Begin- en eindgewicht varkens

- Totale voeropname over de hele productieperiode

- Totale wateropname over de hele productieperiode

- Voersamenstelling (gehalten aan vocht, ruw eiwit, ruw vet, ruwe celstof, overige koolhydraten, as, kalium, fosfor, calcium) en de verteringscoëfficiënten van ruw(e) eiwit, ruw vet en ruwe celstof en overige koolhydraten. Deze verteringscoëfficiënten zijn vaak niet beschikbaar, maar kunnen met behulp van de Veevoedertabel (Anonymus, 2016) berekend worden uit de grondstoffensamenstelling. Uit deze gegevens kan o.a. de opname aan metabolische energie (ME) worden berekend.

De rekentool voert de berekeningen uit over tijdsperioden van één dag en doet dit gedurende de gehele productieperiode. De modelaanpak heeft zoveel mogelijk een mechanistische insteek, echter een aantal relaties zijn empirisch vastgesteld. Daarnaast zijn voor een paar parameters in het model kalibraties uitgevoerd op de eigen meetdata. Dat wil zeggen dat de waarde van een parameter (b.v. een regressiecoëfficiënt) is ingeschat op basis van de beste fit op de gemeten data. Dit geldt voor de volgende parameters voor de verschillende categorieën varkens:

Vleesvarkens

- Drie van de vier parameters om de Gompertz-curves te schatten voor diergewicht en de cumulatieve voer- en wateropname. De vierde parameter van elke curve wordt berekend op basis van het gemeten begin- en eindgewicht en de totale voer- en wateropnames gedurende de groeiperiode.

Biggen

- Eén van de drie parameters om de exponentiële curves te schatten voor diergewicht en de cumulatieve voer- en wateropname. De andere twee parameter van elke curve worden berekend op basis van het gemeten begin- en eindgewicht en de totale voer- en wateropnames gedurende de groeiperiode.

- Het aandeel latente warmteafgifte in de totale warmteafgifte (=warmteproductie) 
Drachtige zeugen

- De water/voer verhouding om de wateropname te berekenen, wanneer de voeropname bekend is.

Alle categorieën

- $\quad$ De verhouding tussen water- en eiwitaanzet

- Regressiecoëfficiënt om de verdampingscoëfficiënt voor de vloer / mestkelder te berekenen uit de wortel van de luchtsnelheid.

- Berekening uitscheiding van potentieel NH4-N (NH4-N + ureum-N; kg/d) uit de totale Nuitscheiding via de urine.

- Oppervlaktetemperatuur van bovenste laag mest en van de urineplassen op de vloer.

- Berekening $\mathrm{NH} 4-\mathrm{N}$ gehalte van urineplassen op basis van het ureum- $\mathrm{N}$ gehalte van verse urine.

- $\quad$ Berekening bulk pH uit NH4-N en azijnzuur gehaltes van de bulk mest en het gehalte aan toegevoegd calciumcarbonaat aan het voer.

- $\quad$ Berekening $\mathrm{pH}$ aan het oppervlak op basis van de $\mathrm{pH}$ van de bulk mest. Deze regressielijn is op basis van lab-metingen tot stand gekomen.

- $\quad$ Relatie tussen het benzoëzuurgehalte van het voer en de $\mathrm{pH}$ van de urineplas.

In de hiernavolgende paragrafen wordt het rekenmodel beschreven dat ontwikkeld is voor vleesvarkens (paragraaf 2.1 - 2.5). Zoals hiervoor aangegeven zijn de rekenregels voor gespeende biggen en zeugen vrijwel gelijk. Verschillen in de rekenregels voor gespeende biggen worden aangegeven in paragraaf 2.6 en verschillen in rekenregels voor zeugen worden aangegeven in paragraaf 2.7. In paragraaf 2.2 wordt het gewichtsverloop van de vleesvarkens en de voer- en wateropname gemodelleerd, in paragraaf 2.3 de hoeveelheden en concentraties van de relevante componenten in de mest, paragraaf 2.4 de hoeveelheid en concentraties van de relevante componenten in de mestkelder na een bepaalde opslagperiode en in paragraaf 2.5 de processen die optreden bij de emissie van ammoniak vanaf de vloer en vanuit de mestkelder.

Er wordt in de paragrafen steeds aangegeven wanneer de vergelijkingen en parameter-waarden zijn verkregen door middel van kalibratie op gemeten data. Kalibratie is gedaan met behulp van de kleinste kwadraten methode, volgens de volgende formule:

$G K_{V}=\sum_{1}^{n}\left(\frac{\left(V_{\text {gemeten }}-V_{\text {berekend }}\right)}{V_{\text {gemeten }}}\right)^{2} / n$

Waarin: $G_{K_{v}}$ is het gemiddelde kwadraat van het relatieve verschil tussen gemeten en berekende waarden van een bepaalde variabele

$\mathrm{V}_{\text {gemeten }}$ is de gemeten waarde van de variabele

Vberekend is de berekende waarde van de variabele

$\mathrm{n}$ is het aantal waarnemingen

De kleinste waarde van GKv werd beschouwd als de beste fit voor de betreffende parameter of combinatie van parameters. 


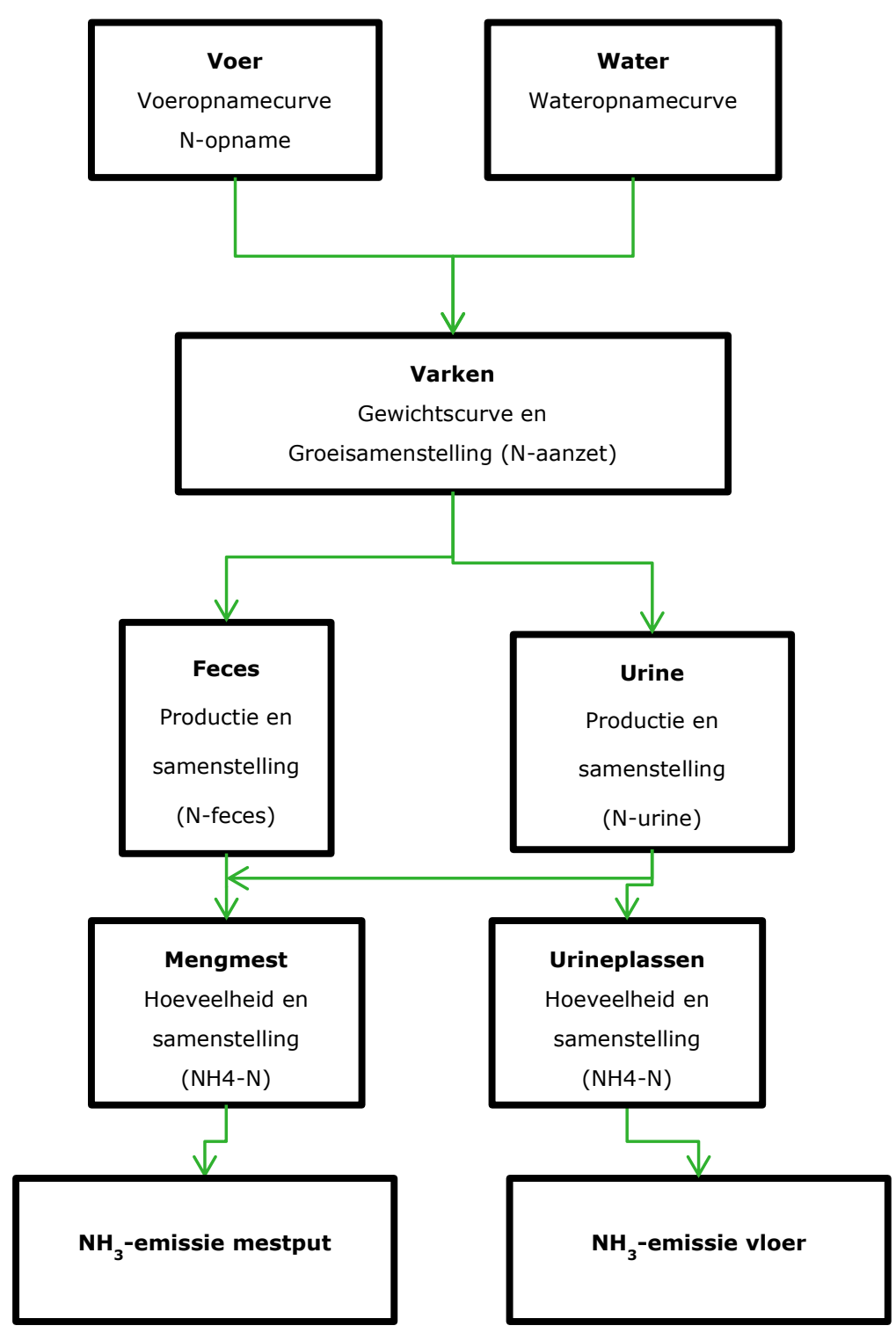

Figuur 1. Schematische weergave van de opbouw van de rekentool voor schatting van de ammoniakemissie uit varkensstallen. 


\subsection{Gewichtsverloop vleesvarkens en voer- en wateropname}

Groeicurves worden vaak beschreven met een Gompertz-curve. Dit is een S-vormige curve met in het begin van de groeiperiode een exponentiële toename van het gewicht, vervolgens een afnemende toename, om tenslotte te stabiliseren op het volwassen eindgewicht. De Gompertz-curve ziet er als volgt uit:

$W_{t}=A+W_{m} \cdot \exp \left\{-\exp \left[-B\left(t-t^{*}\right)\right]\right\} / 1000$

Waarin: $W_{t}$ is het gewicht van het dier op tijdstip $t(\mathrm{~kg})$

A is een constante $(\mathrm{kg})$

$W_{m}$ is het volwassen eindgewicht van het dier $(\mathrm{kg})$

$B$ is een parameter die de vorm van de groeicurve bepaald (deze bepaalt de snelheid van het bereiken van het eindgewicht $\left(\right.$ dag $\left.^{-1}\right)$

$t$ is de leeftijd (dag)

$\mathrm{t}^{*}$ is het tijdstip waarop de groei maximaal is (dag)

$1000=$ omrekening van gram naar kilogram

De parameters in het model $A, W_{m}, B$ en $t^{*}$ zijn bepaald met regressieanalyse op de gemeten data in dit onderzoek (Genstat Committee, 2015). In tabel 2 worden de geschatte parameters weergegeven. Uit de regressieanalyse bleek dat de opname van de constante A geen verbetering gaf van de fit, daarom werd deze op nul gezet. Ferguson \& Gous (1993) vonden een B-waarde voor de totale eiwitaanzet van 0,0107 voor beren en van 0,0120 voor zeugen. Ferguson \& Kyriazis (2003) vonden geen effect van genotype op de B-waarden voor eiwit-, vet-, water- en as-aanzet. Deze varieerde voor al deze componenten tussen de 0,0101 en 0,0123. De hiervoor genoemde waarden zijn lager dan de waarde gevonden in dit onderzoek. Dit wordt waarschijnlijk veroorzaakt door de verdere genetische ontwikkeling van de varkens in de laatste decennia, waardoor de varkens sneller groeien en eerder het volwassen gewicht bereiken.

Het geschatte volwassen eindgewicht is slechts een ruwe inschatting, omdat dit gewicht door vleesvarkens niet gehaald wordt. Deze parameter maken we variabel in onze rekentool, terwijl de andere waarden vast worden gezet op de waarden, zoals weergegeven in tabel 2 . Door één parameter variabel te maken creëren we de mogelijkheid om de curve te fitten op het bereikte eindgewicht, wat een inputgegeven is in ons model. Dit houdt wel in dat $W_{m}$ niet altijd een reële waarde zal opleveren. De waarde gegeven in tabel 2 lijkt ook beduidend lager te zijn dan de werkelijke waarde.

Het verloop van de totale voer- en drinkwateropname laat ook een S-vormig verloop zien. Daarom beschrijven we dit verloop ook met de Gompertz-curve. Een verschil met het verloop van het diergewicht is dat het diergewicht een asymptoot kent, namelijk bij het volwassen eindgewicht ( groei=0), terwijl de voer- en drinkwateropname per dag op een gegeven moment min of meer constant is en de totale voer- en drinkwateropname lineair toeneemt met de tijd. Voor vleesvarkens hoeft dit laatste deel van de curve echter niet beschreven te worden, omdat de dieren het volwassen gewicht niet bereiken, waardoor de Gompertz-curve ook voldoet voor beschrijving van de voer- en wateropname. De geschatte parameters van de curves voor voer- en wateropname worden gegeven in tabel 3. Ook bij deze curves creëren we bij toepassing in de rekentool de mogelijkheid om één parameter te schatten, omdat we de totale voer- en wateropname gedurende de gehele groeiperiode als input benutten. Vergelijkbaar als voor het gewichtsverloop maken we de parameters voor de asymptootwaarde $\mathrm{FI}_{\mathrm{m}}$ en $\mathrm{DWI}$ variabel in het rekenmodel. 


\section{Tabel 2}

Geschatte parameters van de Gompertz-curve (zie formule 2), door regressie op eigen data, voor berekening van het gewicht van vleesvarkens. Tussen haakjes zijn de standaard deviaties weergegeven.

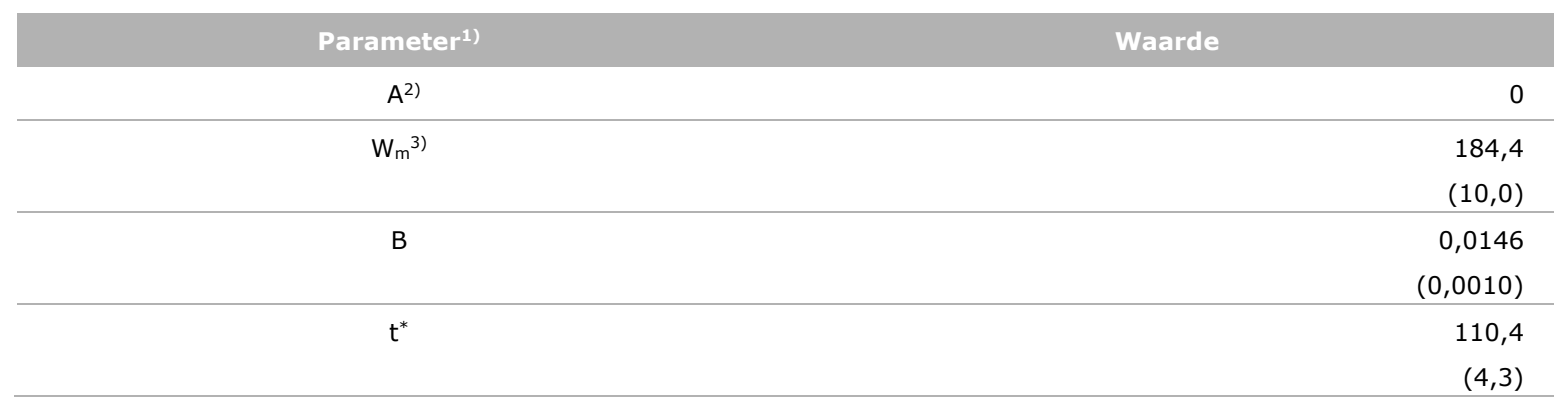

1) Voor verklaring van de variabelen zie formule 2.

2) De constante is op nul gezet, omdat opname hiervan in de regressieformule geen betere fit gaf.

3) Deze waarde wordt in het model gefit op de inputgegevens (begin- en eindgewicht van de varkens).

\section{Tabel 3}

Geschatte parameters van de Gompertz-curve (zie formule 2), door regressie op eigen data, voor berekening van het verloop van de totale voer- en drinkwateropname. Tussen haakjes zijn de standaard deviaties weergegeven.

\begin{tabular}{|c|c|c|}
\hline Parameter ${ }^{1)}$ & $\begin{array}{c}\text { Voeropname } \\
\text { (kg) }\end{array}$ & $\begin{array}{c}\text { Drinkwateropname } \\
(\mathbf{k g})\end{array}$ \\
\hline \multirow[t]{2}{*}{ A } & $-41,9$ & -149 \\
\hline & $(13,1)$ & (108) \\
\hline \multirow[t]{2}{*}{$\mathrm{FI}_{\mathrm{m}} / \mathrm{DWI}_{\mathrm{m}}^{2)}$} & 650 & 1568 \\
\hline & (109) & $(647)$ \\
\hline B & $(0,0017)$ & $(0,0042)$ \\
\hline \multirow[t]{2}{*}{$t^{*}$} & 154,7 & 147,4 \\
\hline & $(10,8)$ & $(23,9)$ \\
\hline
\end{tabular}

1) FIm en DWIm zijn de parameters voor voer- en drinkwateropname, vergelijkbaar met $W_{m}$ voor de groeicurve. In tegenstelling tot de groeicurve blijven de voer- en wateropname niet onder een bepaalde asymptoot, maar nemen op een gegeven moment min of meer lineair toe in de tijd. Voor verklaring van de overige variabelen zie formule 2 .

2) Deze waarden worden in het model gefit op de inputgegevens (totale voer- en wateropnames van de varkens).

\subsection{Hoeveelheid en samenstelling van de uitgescheiden mest}

Om de hoeveelheid en de samenstelling van de uitgescheiden mest te bepalen wordt eerst de aanzet in het dier bepaald van eiwit, vet, as en water. De samenstelling van de groei wordt bepaald met behulp van de energie- en de massabalans. De waterverdamping door het dier wordt berekend uit de latente warmteafgifte.

In de hierna volgende formules wordt de energie- en massabalans gebruikt om de groeisamenstelling te berekenen. De eiwit- en de vetaanzet blijven uiteindelijk over als twee onbekenden die met behulp van de energie- en de massabalansformules kunnen worden berekend. 
De hoeveelheid verteerbare energie in het voer kan als volgt berekend worden uit de voersamenstelling (input in model) (van Milgen et al., 2008):

$D E_{\text {feed }}=23,31 d c p+39,00 d c f+17,54$ starch $+16,71$ sugar $+18,58$ rest_carbo

Waarin: $D E_{\text {feed }}$ is het gehalte aan verteerbare energie $(\mathrm{MJ} / \mathrm{kg})$

$\mathrm{dcp}$ is het verteerbaar ruw-eiwit gehalte $(\mathrm{kg} / \mathrm{kg})$

dcf is het verteerbaar ruw-vet gehalte $(\mathrm{kg} / \mathrm{kg})$

starch is het gehalte aan zetmeel $(\mathrm{kg} / \mathrm{kg})$

sugar is het gehalte aan suiker $(\mathrm{kg} / \mathrm{kg})$

rest_carbo is het gehalte aan overige koolhydraten $(\mathrm{kg} / \mathrm{kg})$

De opname aan metaboliseerbare energie per dag kan berekend worden door de energie uitgescheiden via de urine van de verteerbare energie af te trekken:

$M E_{\text {intake }}=D E_{\text {feed }} \cdot F I-E_{\text {urine }}$

Waarin: $M E_{\text {intake }}$ is opname aan metaboliseerbare energie $(\mathrm{MJ} / \mathrm{d})$

$\mathrm{DE}_{\text {feed }}$ is het gehalte aan verteerbare energie $(\mathrm{MJ} / \mathrm{kg})$

$\mathrm{FI}$ is de voeropname $(\mathrm{kg} / \mathrm{d})$

Eurine is de energie-uitscheiding via de urine $(\mathrm{MJ} / \mathrm{d})$

De metaboliseerbare energieopname per dag is gelijk aan de som van de energie voor onderhoud en de energie beschikbaar voor productie (groei in geval van vleesvarkens) (Kielanowski, 1965):

$M E_{\text {intake }}=M E_{m}+M E_{\text {prod }}$

Waarin: $M E_{\text {intake }}$ is opname aan metaboliseerbare energie $(\mathrm{MJ} / \mathrm{d})$

MEm is metaboliseerbare energie voor onderhoud $(M J / d)$

$M E_{\text {prod }}$ metaboliseerbare energie beschikbaar voor groei $(M J / d)$

In de literatuur bestaan verschillende formules voor berekening van de hoeveelheid benodigde energie voor onderhoud $\left(\mathrm{MEm}_{\mathrm{m}}\right)$. Meestal hebben deze formules de volgende vorm:

$M E_{m}=a \cdot W^{b}$

Waarin: $M E_{m}$ is metaboliseerbare energie voor onderhoud $(M J / d)$

$W$ is diergewicht $(\mathrm{kg})$

a en b zijn coëfficiënten

Van Milgen \& Noblet (2003) vonden op basis van eigen data een b-waarde van 0,60 en een a-waarde die varieerde afhankelijk van de activiteit van de dieren tussen de 0,85 en 1,00. De regressielijn bij een a-waarde van 0,85 komt goed overeen met andere onderzoeken (CIGR, 2002; Fowler et al., 2013), daarom kiezen we deze waarde voor ons model.

De metaboliseerbare energie voor groei kan als volgt worden berekend (Kielanowski, 1965):

$M E_{\text {prod }}=\frac{E_{P}}{k_{P}} \cdot B_{P}+\frac{E_{L}}{k_{L}} \cdot B_{L}$

Waarin: $M E_{\text {prod }}$ is metaboliseerbare energie beschikbaar voor groei $(\mathrm{MJ} / \mathrm{d})$

$E_{p}$ is energie in eiwit $(M J / k g)$

$E_{L}$ is energie in vet $(M J / k g)$

$k_{P}$ is de efficiëntie van eiwitaanzet, de rest wordt omgezet in warmte (MJ/MJ)

$\mathrm{kL}$ is de efficiëntie van vetaanzet, de rest wordt omgezet in warmte (MJ/MJ)

Bp is de eiwitaanzet $(\mathrm{kg} / \mathrm{d})$

$B_{L}$ is de vetaanzet $(\mathrm{kg} / \mathrm{d})$ 
Volgens Van Milgen \& Noblet (2003) is de energie in aangezet vet gelijk aan 39,8 MJ/kg (EL) en de energie in aangezet eiwit $23,8 \mathrm{MJ} / \mathrm{kg}\left(\mathrm{E}_{\mathrm{P}}\right)$. Volgens dezelfde auteurs is de energie-efficiëntie van eiwitaanzet $\left(k_{P}\right)$ 0,60 MJ/MJ en de energie-efficiëntie van vetaanzet( $\left.k_{L}\right)$ 0,80 MJ/MJ. De eiwit- en vetaanzet kunnen nu met de volgende twee formules worden berekend:

$B_{P}=G \cdot f_{s c}-B_{L}-B_{A s h}-B_{W}$

Waarin: $\quad B_{p}$ is de eiwitaanzet $(\mathrm{kg} / \mathrm{d})$

$\mathrm{G}$ is de groei $(\mathrm{kg} / \mathrm{d})$

$\mathrm{f}_{\mathrm{sc}}$ is de correctiefactor voor toename maagdarminhoud (-)

$B_{L}$ is de vetaanzet $(\mathrm{kg} / \mathrm{d})$

$B_{A s h}$ is de as-aanzet $(\mathrm{kg} / \mathrm{d})$

$B_{w}$ is de wateraanzet $(\mathrm{kg} / \mathrm{d})$

$B_{L}=\left(M E_{\text {prod }}-B_{P} \cdot \frac{E_{P}}{k_{P}}\right) /\left(\frac{E_{L}}{k_{L}}\right)$

Waarin: $\quad B_{L}$ is de vetaanzet $(\mathrm{kg} / \mathrm{d})$

$M E_{\text {prod }}$ is de metaboliseerbare energie beschikbaar voor groei $(\mathrm{MJ} / \mathrm{d})$

$B_{p}$ is de eiwitaanzet $(\mathrm{kg} / \mathrm{d})$

$E_{P} / E_{L}$ energie in eiwit en vet ( $\left.M J / k g\right)$

$k_{p}$ en $k_{L}$ efficiëntie-coëfficiënten voor eiwit- en vetaanzet, rest wordt omgezet in warmte (MJ/MJ)

Hierbij is formule 9 gelijk aan 7, maar met de vetaanzet als de afhankelijke variabele. De eiwitaanzet per dag is begrensd en deze maximale eiwitaanzet is vooral afhankelijk van de genetische aanleg van het varken en verschilt tussen zeugen, beren en borgen (Quiniou et al., 1999). Deze genetische aanleg is sterk veranderd en in de afgelopen decennia is de maximale eiwitaanzet per dag sterk toegenomen. De maximale eiwitaanzet (Bp-max) is input in het model. In ons model gaan we uit van een maximale eiwitaanzet bij vleesvarkens van $170 \mathrm{~g} / \mathrm{d}$. Dit betekent dat de berekende eiwitaanzet in bovenstaande vergelijkingen wordt begrensd op deze maximale waarde en wordt de vetaanzet vervolgens berekend op basis van deze maximale waarde.

De energie-uitscheiding via de urine kan als volgt worden berekend (van Milgen et al., 2008):

$E_{\text {urine }}=0,168 W^{0,175}+31,1 \cdot\left(d c p-B_{P}\right) / 6,25$

Waarin: Eurine is de energie-uitscheiding via de urine $(\mathrm{MJ} / \mathrm{d})$

$\mathrm{W}$ is diergewicht $(\mathrm{kg})$

$\mathrm{dcp}$ is het verteerbaar ruw-eiwit gehalte $(\mathrm{kg} / \mathrm{kg})$

$B_{p}$ is de eiwitaanzet $(\mathrm{kg} / \mathrm{d})$

De groei (G) kan bepaald worden uit de groeicurve. De correctiefactor voor de toename van de maagdarminhoud $\left(f_{s c}\right)$ is afhankelijk van het gewicht ( $1^{\mathrm{e}}$ afgeleide van formule in De Lange et al. (2003)):

$f_{s c}=1-0,277 W^{-0,388}$

Waarin: $f_{s c}$ is een correctiefactor voor de toename van de maag- darminhoud (-)

$\mathrm{W}$ is het diergewicht $(\mathrm{kg})$

We veronderstellen dat de toename in maag- darminhoud dezelfde samenstelling heeft als het opgenomen voer en water. Volgens De Lange et al. (2003) is de as-aanzet sterk gelinkt aan de eiwitaanzet:

$B_{A s h}=0,20 B_{P}$

Waarin: $B_{A s h}$ is de as-aanzet $(\mathrm{kg} / \mathrm{d})$

$B p$ is de eiwitaanzet $(\mathrm{kg} / \mathrm{d})$ 
$\mathrm{Er}$ is ook een min of meer vaste verhouding tussen de wateraanzet en de eiwitaanzet. Op basis van informatie van de paper van De Lange et al. (2003) kan deze verhouding als volgt worden berekend ( $1^{\mathrm{e}}$ afgeleide van formule in voornoemde paper):

$B_{W / P}=f_{W / P} \cdot 4,77 W^{-0,141}$

Waarin: $\quad B w / P$ is de verhouding tussen water- en eiwitaanzet (-)

$W$ is gewicht $(\mathrm{kg})$

$\mathrm{fW}_{\mathrm{W} / \mathrm{P}}$ is een correctiefactor voor de genetische ontwikkeling in de laatste 20 jaar

De correctiefactor $\mathrm{f}_{\mathrm{W} / \mathrm{P}}$ is gekalibreerd op het $\mathrm{N}$-gehalte van de mengmest en is vastgesteld op $f_{W / P}=1,11$.

Op basis van bovenstaande formules kan berekend worden hoeveel eiwit, vet, water en anorganische stof (as) wordt vastgelegd in het lichaam. Hierna gaan we berekenen hoeveel en in welke samenstelling de urine en feces worden uitgescheiden.

De totale hoeveelheid water die uitgescheiden wordt in de mest (feces + urine) kan als volgt worden berekend:

$S_{W}=W I+B_{M W}-B_{W}-B_{E v a p}$

Waarin: $S_{w}$ is de hoeveelheid uitgescheiden water in de mest $(\mathrm{kg} / \mathrm{d})$

WI is de wateropname $(\mathrm{kg} / \mathrm{d})$

BMw is het gevormde metabolisch water (door oxidatie van organische stof) $(\mathrm{kg} / \mathrm{d})$

$B_{w}$ is de wateraanzet $(\mathrm{kg} / \mathrm{d})$

$B_{\text {Evap }}$ is de waterverdamping $(\mathrm{kg} / \mathrm{d})$

De wateropname is gelijk aan de drinkwateropname en het water in het voer:

$W I=D W I+F e e d_{W} \cdot F I$

Waarin: DWI is de drinkwateropname $(\mathrm{kg} / \mathrm{d})$

Feedw is het watergehalte van het voer $(\mathrm{kg} / \mathrm{kg})$

$\mathrm{FI}$ is de voeropname $(\mathrm{kg} / \mathrm{d})$

De hoeveelheid gevormd metabolisch water kan als volgt worden berekend uit de verteerde organische stofcomponenten en de aanzet van eiwit en vet (Aarnink et al., 1992):

$B_{M W}=0,556 \cdot(d c f+d r c) \cdot F I+1,071 \cdot\left(d c f \cdot F I-B_{L}\right)+0,396 \cdot\left(d c p \cdot F I-B_{P}\right)$

Waarin: $B_{M w}$ is de hoeveelheid gevormd metabolisch water $(\mathrm{kg} / \mathrm{d})$

dcf, drc, dcf en dcp zijn respectievelijk de verteerbare gehalten in het voer van ruwe celstof, overige koolhydraten, ruw vet en ruw eiwit, dit zijn inputgegevens in het model $(\mathrm{kg} / \mathrm{kg})$

$\mathrm{FI}$ is de voeropname, berekend uit de Gompertz-curve $(\mathrm{kg} / \mathrm{d})$

$B_{\llcorner}$en $B_{P}$ zijn de vet- en eiwitaanzet $(\mathrm{kg} / \mathrm{d})$

De waterverdamping kan berekend worden uit de latente warmteafgifte:

$Q l=f_{Q l} \cdot Q t o t$

Waarin: Ql is de latente warmteafgifte $(\mathrm{MJ} / \mathrm{d})$

$\mathrm{f}_{\mathrm{Q}}$ is het aandeel van de totale warmteproductie dat als latente warmte wordt afgegeven (MJ/MJ)

Qtot is de totale warmteproductie (MJ/d) 
Qtot kan berekend worden door de energie in de eiwit- en vetaanzet van de opgenomen metaboliseerbare energie (ME) af te trekken.

$Q t o t=M E-B_{P} \cdot E_{P}-B_{L} \cdot E_{L}$

Waarin: Qtot is de totale warmteproductie ( $\mathrm{MJ} / \mathrm{d}$ )

ME is opname aan metaboliseerbare energie $(\mathrm{MJ} / \mathrm{d})$

$B p$ is de eiwitaanzet $(\mathrm{kg} / \mathrm{d})$

$B_{L}$ is de vetaanzet $(\mathrm{kg} / \mathrm{d})$

Ep is energie in eiwitaanzet $(\mathrm{MJ} / \mathrm{kg})$

$E_{L}$ is energie in vetaanzet $(\mathrm{MJ} / \mathrm{kg})$

Volgens Aarnink et al. (1992) kan het aandeel afgegeven latente warmte door het dier (op dierniveau) als volgt worden berekend:

$f_{Q l-a n i m a l}=0,10+3,54 \cdot 10^{-7} \cdot T i^{4}$

Waarin: $\mathrm{f}_{\mathrm{Ql}-\text {-animal }}$ is het aandeel latente warmteafgifte van de totale warmteafgifte (=totale warmteproductie) (-)

$\mathrm{Ti}$ is de omgevingstemperatuur van het dier (staltemperatuur) $\left({ }^{\circ} \mathrm{C}\right)$

De waterverdamping kan nu worden berekend door QI te delen door de verdampingswarmte van water, die als volgt wordt berekend:

$c_{L}=2,497-0,0020 \cdot T_{b}$

Waarin: $C_{L}$ is de verdampingswarmte van water $(\mathrm{MJ} / \mathrm{kg})$

$\mathrm{T}_{\mathrm{b}}$ is de lichaamstemperatuur van het $\operatorname{dier}\left({ }^{\circ} \mathrm{C}\right)$

De uitscheiding van drogestof (ds) kan berekend worden door de onverteerde organische stof (os) te sommeren met de hoeveelheid os die uitgescheiden wordt via de urine en met het verschil tussen anorganische stof (as) opname en as-aanzet.

$S_{D M}=$ Feed $_{O M} \cdot\left(1-d c_{O M}\right) \cdot F I+U_{O M}+F e e d_{A s h} \cdot F I-B_{A s h}$

Waarin: $S_{D M}$ is de uitgescheiden ds in de mest $(\mathrm{kg} / \mathrm{d})$

Feedom is het os gehalte van het voer, input in model $(\mathrm{kg} / \mathrm{kg})$

dcom is de verteringscoëfficiënt van de os, input in model $(\mathrm{kg} / \mathrm{kg})$

$\mathrm{FI}$ is de voeropname, berekend in model $(\mathrm{kg} / \mathrm{d})$

$\mathrm{U}_{\mathrm{O}}$ is de uitgescheiden os in de urine $(\mathrm{kg} / \mathrm{d})$

Feed $_{\text {Ash }}$ is as gehalte van het voer, input in model $(\mathrm{kg} / \mathrm{kg})$

$B_{\text {Ash }}$ is de as-aanzet $(\mathrm{kg} / \mathrm{d})$

De opname aan os is gelijk aan de som van de opnames van ruw eiwit, ruw vet, ruwe celstof en overige koolhydraten. De verteringscoëfficiënt van de os kan berekend worden uit de verteerbaarheden van de hiervoor genoemde componenten. Voor berekening van de uitgescheiden hoeveelheid os met de urine wordt voor de eenvoud verondersteld dat alle os en $\mathrm{N}$ in de urine in de vorm van ureum aanwezig:

$U_{O M}=\frac{60}{28} \cdot U_{N t o t}$

Waarin: $U_{\text {om }}$ is de uitgescheiden organische stof in urine $(\mathrm{kg} / \mathrm{d})$

$\mathrm{U}_{\text {Ntot }}$ is de totale hoeveelheid uitgescheiden $\mathrm{N}$ in urine $(\mathrm{kg} / \mathrm{d})$

$60 / 28$ is de omrekening van $\mathrm{N}$ naar ureum 
De totale hoeveelheid uitgescheiden urine- $\mathrm{N}$ kan berekend worden door de aangezette $\mathrm{N}$ af te trekken van de verteerde N. Hierbij wordt uitgegaan van de eiwitverteerbaarheid (input in model) en de eiwitaanzet (berekend). Voor de omrekening van eiwit naar $\mathrm{N}$ wordt de factor 6,25 gebruikt.

$U_{N}=(d c p \cdot F I-G P) / 6,25$

Waarin: $U_{N}$ is de uitgescheiden stikstof in urine $(\mathrm{kg} / \mathrm{d})$

dcp is het verteerbare gehalte in het voer van ruw eiwit $(\mathrm{kg} / \mathrm{kg})$

$\mathrm{FI}$ is de voeropname $(\mathrm{kg} / \mathrm{d})$

GP is de eiwitaanzet $(\mathrm{kg} / \mathrm{d})$

De totale hoeveelheid uitgescheiden $\mathrm{N}$ wordt berekend door de $\mathrm{N}$-aanzet af te trekken van de $\mathrm{N}$ opname.

$S_{N}=(c p \cdot F I-G P) / 6,25$

Waarin: $\mathrm{S}_{\mathrm{N}}$ is de uitgescheiden stikstof in de mengmest $(\mathrm{kg} / \mathrm{d})$

$\mathrm{cp}$ is het ruw eiwitgehalte in het voer $(\mathrm{kg} / \mathrm{kg})$

$\mathrm{FI}$ is de voeropname $(\mathrm{kg} / \mathrm{d})$

$\mathrm{GP}$ is de eiwitaanzet $(\mathrm{kg} / \mathrm{d})$

De potentiële uitscheiding van $\mathrm{NH} 4-\mathrm{N}$ (totaal van ureum- $\mathrm{N}$ en $\mathrm{NH} 4-\mathrm{N}$ ) in verse urine wordt berekend uit de totale $\mathrm{N}$-uitscheiding in de verse urine (andere $\mathrm{N}$-verbindingen vormen de rest van de $\mathrm{N}$ ):

$U_{N H 4 N-p o t}=-2,7 \cdot 10^{-4}+0,87 \cdot U_{N t o t}$

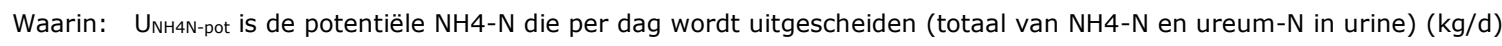
$U_{\text {Ntot }}$ is de totale hoeveelheid uitgescheiden $N$ in urine $(\mathrm{kg} / \mathrm{d})$

Uit de metingen blijkt dat bij vleesvarkens $11,0 \%$ (s.e. 0,3\%) van de feces- $\mathrm{N}$ aanwezig is in de vorm van NH4-N. De verwachting is dat deze NH4-N niet of nauwelijks emitteert vanaf de vloer. Voor bepaling van het NH4-N gehalte van de mengmest in de mestkelder is deze echter wel van belang.

De totale uitscheiding van (verse) mest wordt berekend door de uitscheiding van water ( $\mathrm{Sw}$ ) en ds ( $\mathrm{S}_{\mathrm{DM}}$ ) bij elkaar op te tellen. Om de $\mathrm{N}$-concentraties in de verse urine te kunnen berekenen moet naast de reeds berekende $\mathrm{N}$-uitscheiding de hoeveelheid uitgescheiden urine worden vastgesteld. Deze hoeveelheid is gelijk aan het verschil tussen de hiervoor berekende mestproductie en de fecesuitscheiding.

Voor de berekening van de feces uitscheiding wordt de volgende relatie tussen het ds-gehalte van de feces en het diergewicht (Aarnink, 1991) gebruikt:

$F_{D M}=0,176+1,19 \cdot 10^{-3} \cdot W$

Waarin: FDM is het ds-gehalte van de feces $(\mathrm{kg} / \mathrm{kg})$

$\mathrm{W}$ is het diergewicht $(\mathrm{kg})$

De feces-productie kan vervolgens worden berekend door de onverteerde organische stof (os) en anorganische stof (as) te berekenen. De verteringscoëfficiënten van de os en de as zijn input in het model. De hoeveelheid uitgescheiden urine kan vervolgens worden berekend door de feces-productie van de mestproductie per dag af te trekken.

De vastlegging in het lichaam van respectievelijk fosfor (P) en calcium (Ca) (Aarnink et al., 1992) en kalium (K) (Aarnink, 1991) wordt als volgt berekend :

$B_{P}=0,005467 \cdot W^{-0,025} \cdot G$

$B_{C a}=0,007996 \cdot W^{0,005} \cdot G$

$B_{K}=\left(4,2-6,8 \cdot 10^{-2} \cdot W+4,7 \cdot 10^{-4} \cdot W^{2}\right) \cdot G / 1000$

Waarin: $B X$ is de vastlegging van mineraal $X$ in het lichaam $(\mathrm{kg} / \mathrm{d})$

$W$ is het diergewicht $(\mathrm{kg})$

$\mathrm{G}$ is de groei $(\mathrm{kg} / \mathrm{d})$ 


\subsection{Hoeveelheid en samenstelling van de mengmest in de mestkelder}

De hoeveelheid mest in de mestkelder kan als volgt worden berekend:

$S_{\text {Total-pit }}=S_{D M-\text { total-pit }}+S_{W-\text { total-pit }}$

Waarin: STotal-pit is de hoeveelheid mengmest in de mestkelder $(\mathrm{kg})$

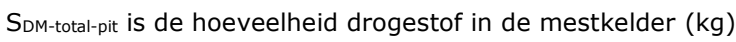

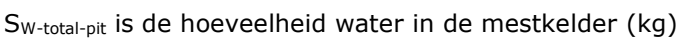

$S_{D M-t o t a l-p i t}=\sum_{0}^{t}\left(S_{D M-t}-\right.$ Biogas $_{t}-$ Urea $\left._{C O 2-t}\right)$

Waarin: SDM-total-pit is de hoeveelheid drogestof in de mestkelder $(\mathrm{kg})$

SDM-t is de hoeveelheid uitgescheiden drogestof door het dier op dag $\mathrm{t}(\mathrm{kg})$

Biogast is de hoeveelheid gasproductie op dag $\mathrm{t}(\mathrm{kg})$

Ureaco2-t is de correctie voor vorming van $\mathrm{CO}_{2}$ bij de hydrolyse van ureum op dag $\mathrm{t}(\mathrm{kg})$.

$S_{W-\text { total-pit }}=\sum_{0}^{t}\left(S_{W-t}-\operatorname{evap}_{\text {Floor }}-\right.$ evap $\left._{\text {pit }}\right)$

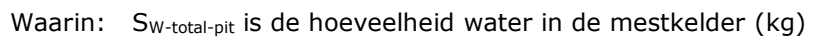

$\mathrm{S}_{\mathrm{W}-\mathrm{t}}$ is de hoeveelheid uitgescheiden water door het dier op dag $\mathrm{t}(\mathrm{kg})$

evapfloor is de waterverdamping vanaf de vloer op dag $\mathrm{t}(\mathrm{kg})$

evap $_{\text {pit }}$ is de waterverdamping uit de mestkelder op dag $\mathrm{t}(\mathrm{kg})$

Bij de hydrolyse van ureum worden $2 \mathrm{NH}_{3}$ moleculen en $1 \mathrm{CO}_{2}$ molecuul gevormd. De hoeveelheid ds die overblijft bij ureumuitscheiding is daarmee een factor $34 / 60 *$ ureumuitscheiding. De afname van de waterhoeveelheid als gevolg van de benodigde watermoleculen bij hydrolyse wordt verwaarloosd.

De waterverdamping vanaf natte vloeroppervlakken en vanuit de mestkelder is gerelateerd aan het dampspanningsverschil tussen het natte oppervlak en de lucht en is evenredig met de grootte van het verdampend oppervlak. Deze verdamping kan voor natte vloeroppervlakken en vanuit de mestkelder als volgt worden berekend:

$$
\begin{aligned}
& \operatorname{evap}_{\text {floor }}=k_{-} \operatorname{evap}_{\text {floor }} \cdot\left(p_{\text {floor }}-p_{\text {air }}\right) \cdot A_{\text {wet-floor }} \\
& \operatorname{evap}_{\text {pit }}=k_{-} \operatorname{evap}_{\text {pit }} \cdot\left(p_{\text {pit }}-p_{\text {air }}\right) \cdot A_{\text {wet-pit }}
\end{aligned}
$$

Hierbij wordt verondersteld dat de relatieve luchtvochtigheid van het verdampend oppervlak van vloer en mestkelder $100 \%$ is. De dampspanningen zijn berekend met formules van Albright (1990). Volgens Beeking et al. (1994) is de verdampingscoëfficiënt evenredig met de wortel uit de luchtsnelheid over het verdampend oppervlak:

$k_{\text {evap }}=b_{k_{\text {evap }}} \cdot \sqrt{v_{\text {surface }}}$

Waarin: $\quad k_{\text {evap }}$ is de verdampingscoëfficiënt voor de vloer / mestkelder $\left(\mathrm{kg} /\left(\mathrm{m}^{2} . \mathrm{kPa} \cdot \mathrm{d}\right)\right)$

$b_{\text {kevap }}$ is een regressiecoëfficiënt

$\mathrm{V}_{\text {surface }}$ is de luchtsnelheid over het verdampend oppervlak $(\mathrm{m} / \mathrm{s})$

De regressiecoëfficiënt $b$ is met behulp van de kleinste kwadraten methode (zie formule 1, par. 2.1; stappen van 0,01 ) op de gemeten verdampingsdata geschat. Uit deze analyse werd een bevap geschat van 7,69 . 
De luchtsnelheid over het mestoppervlak in de mestkelder wordt berekend met behulp van de volgende op de data gefitte relatie met het ventilatiedebiet per $\mathrm{m}^{2}$ staloppervlak:

$v_{\text {surface_pit }}=0,091+14,2 \cdot$ vent $_{m^{2}}$

Waarin: Vsurface_pit is de luchtsnelheid over het verdampend kelderoppervlak $(\mathrm{m} / \mathrm{s})$

vent $_{\mathrm{m} 2}$ is het ventilatiedebiet per $\mathrm{m}^{2}$ staloppervlak $\left(\mathrm{m}^{3} / \mathrm{s}\right.$ per $\mathrm{m}^{2}$ staloppervlak)

Er werd geen significante relatie gevonden tussen de luchtsnelheid gemeten net boven de met urine bevuilde vloeroppervlakken en het ventilatiedebiet per $\mathrm{m}^{2}$ staloppervlak, daarom wordt deze luchtsnelheid constant verondersteld:

$v_{\text {Surface_floor }}=0,146$

Waarin: Vsurface_floor is de luchtsnelheid over het verdampend vloeroppervlak $(\mathrm{m} / \mathrm{s})$

Voor de berekening van de ammoniakemissie vanaf de schuine wanden is de luchtsnelheid en de temperatuur van het emitterend oppervlak gelijk verondersteld aan die van de mest in de kelder.

De volgende relatie werd gevonden tussen de temperatuur van het emitterend oppervlak in de mestkelder en de temperatuur van de uitgaande stallucht:

$T_{\text {surface_manure }}=1,85+0,735 \cdot T_{\text {exhaust }}$

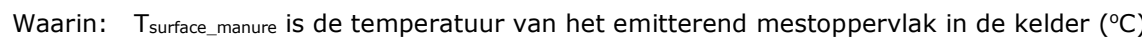

Texhaust is de temperatuur van de uitgaande stallucht $\left({ }^{\circ} \mathrm{C}\right)$

Met deze regressielijn kon $42 \%$ van de variatie in de gemeten oppervlaktetemperatuur van de mest in de kelder worden verklaard. De oppervlaktetemperatuur van de urineplassen ( $T_{\text {surface_floor }}$ ) was vergelijkbaar met de temperatuur van de uitgaande lucht (regressiecoëfficiënt was gelijk aan 1,01 (s.e. 0,02$)$ ) en werd daarom gelijk gesteld aan deze temperatuur.

De biogasproductie wordt berekend met behulp van de formules van Aarnink et al. (1992). Hierbij wordt de volgende relatie gebruikt om de mesttemperatuur te berekenen:

$T_{\text {bulk_manure }}=1,36+0,813 \cdot T_{\text {exhaust }}$

Waarin: Tbulk_manure is de temperatuur van de bulk mest $\left({ }^{\circ} \mathrm{C}\right)$

Texhaust is de temperatuur van de uitgaande stallucht $\left({ }^{\circ} \mathrm{C}\right)$

Met deze regressielijn kon $70 \%$ van de variatie in de mesttemperatuur, gemeten op $5 \mathrm{~cm}$ onder het oppervlak, worden verklaard. De mestkelders in dit onderzoek waren steeds slechts voor een deel gevuld. Daarom zal de gemeten mesttemperatuur op $5 \mathrm{~cm}$ diept waarschijnlijk niet veel afwijken van de gemiddelde mesttemperatuur. Bij vollere mestkelders zal de relatie met de uitgaande staltemperatuur waarschijnlijk geringer zijn. Met de biogasmodule in het rekenmodel wordt de hoeveelheid organische stof die afgebroken wordt in de mengmest berekend. Hieruit kan tevens de biogasproductie (totaal van $\mathrm{CO}_{2}$ en $\mathrm{CH}_{4}$ ), de vorming van vluchtige vetzuren (waaronder azijnzuur) en de vorming van $\mathrm{NH} 4-\mathrm{N}$ uit afgebroken eiwitten worden berekend. 


\section{$2.5 \quad$ Ammoniakemissie}

De ammoniakemissie kan als volgt worden berekend (Aarnink \& Elzing, 1998):

$E_{N H 3}=\frac{k_{N H 3} \cdot A \cdot f \cdot[N H 4 N]}{H}$

Waarin: $\mathrm{E}_{\mathrm{NH} 3}$ is de ammoniakemissie (mol/s)

$\mathrm{k}_{\mathrm{NH} 3}$ is de massa transfer coëfficiënt voor ammoniak (m/s)

$A$ is het emitterend oppervlak van de vloer (urineplassen) of van de mestkelder $\left(\mathrm{m}^{2}\right)$

$f$ is de fractie niet geïoniseerde ammoniak in de oplossing (-)

$[\mathrm{NH} 4 \mathrm{~N}]$ is de concentratie ammonium-stikstof $(\mathrm{NH} 4-\mathrm{N})$ in de oplossing $\left(\mathrm{mol} / \mathrm{m}^{3}\right)$

$\mathrm{H}$ is de constante van Henry (-)

De verschillende variabelen / constanten in deze vergelijking kunnen op de volgende manier worden berekend (Aarnink \& Elzing, 1998):

$k_{N H 3}=50.1 \cdot\left(v_{\text {surface }}\right)^{0.8} \cdot\left(T_{\text {surface }}\right)^{-1.4}$

Waarin: $\quad k_{N H 3}$ is de massa transfer coëfficiënt voor ammoniak $(\mathrm{m} / \mathrm{s})$

$\mathrm{V}_{\text {surface }}$ is de luchtsnelheid over het emitterend oppervlak $(\mathrm{m} / \mathrm{s})$

$\mathrm{T}_{\text {surface }}$ is de temperatuur van het emitterend oppervlak $(\mathrm{K})$

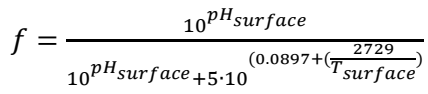

Waarin: $f$ is de fractie niet geïoniseerde ammoniak in de oplossing (-)

$\mathrm{pH}_{\text {surface }}$ is the $\mathrm{pH}$ van de emitterende vloeistof aan het oppervlak (-)

$\mathrm{T}_{\text {surface }}$ is de temperatuur van het emitterend oppervlak (K)

$H=1431 \cdot 1.053^{\left(293-T_{\text {surface }}\right)}$

Waarin: $\mathrm{H}$ is de constante van Henry ()

$\mathrm{T}_{\text {surface }}$ is de temperatuur van het emitterend oppervlak (K)

De luchtsnelheid en de temperatuur van het emitterend oppervlak zijn gelijk aan die berekend zijn voor de waterverdamping in paragraaf 2.4. Het emitterend kelderoppervlak ( $\left.A_{\text {pit}}\right)$ is gelijk aan de afmetingen van de mestkelder (lengte $x$ breedte) bij een mestkelder met rechte wanden. Bij een mestkelder met schuine wanden wordt het emitterend oppervlak beïnvloed door de hoogte van de mest. Deze hoogte kan worden berekend uit de mestproductie van de varkens en de precieze vorm van de mestkelder (zie hfdstk 3). Het percentage van de schuine wanden (bij vleesvarkens en zeugen) dat is bevochtigd met urine is op een paar momenten tijdens het onderzoek bepaald. De bevuiling van de schuine wanden was niet gerelateerd aan het diergewicht, maar wel aan de precieze vormgeving van de schuine wanden. In hoofdstuk 3 zijn de precieze ontwerpen van de hokken, inclusief schuine wanden beschreven. Afdelingen 11 en 12 aan de ene kant en afdelingen 9 en 10 aan de andere kant hadden dezelfde ontwerpen van de hokken. Voor afdelingen 11 en 12 was gemiddeld 13,5\% (s.e. $1.3 \%$ ) van de schuine wand tegen de dichte vloer bevuild met urine en $28,4 \%$ (s.e. $4.3 \%$ ) van de schuine wand tegen de achtermuur van het hok; voor afdelingen 9 en 10 was dit respectievelijk 20,8 (s.e. $2.4 \%$ ) en $37,4 \%$ (s.e. $1.6 \%$ ). Het emitterend vloeroppervlak ( $A_{\text {floor }}$ ) is gelijk aan het oppervlak van de vloer dat bevuild is met urine. Dit oppervlak wordt via waarnemingen bepaald (zie hfdstk 3 ). Hierbij is onderscheid gemaakt tussen bevuiling van de dichte vloer, bevuiling van de betonnen roostervloer (voor in het hok) en bevuiling van de metalen driekant roostervloer (achterin het hok).

Het NH4-N gehalte van de bulk mengmest kan worden berekend door uit te gaan van een volledige omzetting van de ureum in urine naar $\mathrm{NH} 4-\mathrm{N}$. De berekening van de hoeveelheid uitgescheiden potentiële $\mathrm{NH} 4-\mathrm{N}$ (totaal van $\mathrm{NH} 4-\mathrm{N}$ en ureum-N) is weergegeven in par. 2.3. Door de totale hoeveelheid uitgescheiden ureum-N te delen door het mestvolume (berekend in par. 2.4) kan de $\mathrm{NH4-}$ $\mathrm{N}$ concentratie van de bulk mengmest worden berekend. Uit de metingen blijkt dat de potentiële $\mathrm{NH4-}$ $\mathrm{N}$ concentratie van de bovenste laag van de mest gemiddeld een factor 0,81 (s.e. 0,088 ) van de $\mathrm{NH4-}$ $\mathrm{N}$ concentratie is van de bulk mest. Dit wordt waarschijnlijk veroorzaakt doordat de diffusie van ammonium uit de bulk mest naar de bovenlaag minder snel verloopt dan de emissie van ammoniak uit 
deze bovenlaag. Daarnaast blijkt uit de metingen dat niet alle ureum-N in de bovenlaag is omgezet naar NH4-N (voor de wijze waarop dit bepaald is zie hfdstk 3). Regressieanalyse van de meetresultaten laat zien dat gemiddeld een fractie 0,83 (s.e. 0,030) van de ureum- $\mathrm{N}$ in de bovenlaag is omgezet naar NH4-N. Voor bepaling van de concentratie NH4-N aan het mestoppervlak wordt daarom de bulk-concentratie gecorrigeerd voor de beide hiervoor genoemde fracties.

Uit de metingen blijkt dat 19,3\% van de totale hoeveelheid geproduceerde mest in de voorste mestkelder van het hok terecht komt. Dit is het waterkanaal. Dit kanaal is na elke keer aflaten van de mest voor ca. de helft gevuld met water. Uit de starthoeveelheid water en het gemiddelde percentage mest dat in het waterkanaal terecht komt, kan het NH4-N gehalte in dit kanaal worden bepaald.

Doordat de mest in dit kanaal sterk verdund is, wordt verondersteld dat er geen verschil is in het NH4$\mathrm{N}$ gehalte van de bovenste laag van de mest en de bulk mest. Daarnaast veronderstellen we dat alle ureum-N is omgezet naar NH4-N. Dit kunnen we veronderstellen, omdat in dit kanaal door de sterke verdunning de urine niet als een laag boven op de mengmest zal drijven, wat wel gedeeltelijk het geval kan zijn in de achterste mestkelder.

Nadat de urineplas op de (rooster)vloer is terecht gekomen vinden er allerlei processen plaats. De ureum wordt m.b.v. het enzym urease, dat veelal ruim op de vloer voorradig is, omgezet naar ammoniak, dat vervolgens in de oplossing blijft in de vorm van ammonium. Een deel van de ammonium emitteert in de vorm van ammoniak naar de lucht. Ook verdampt er water vanuit de plas naar de lucht. Aangezien we geen dynamisch model maken, maar statisch de situatie vast willen stellen zoals die op een bepaald moment is, kiezen we er voor om het $\mathrm{NH} 4-\mathrm{N}$ gehalte van de urineplas direct te berekenen uit het ureum- $\mathrm{N}$ gehalte van de verse urine. Er werd een verhouding tussen de gemeten $\mathrm{NH} 4-\mathrm{N}$ gehaltes van de urineplassen en de gemeten ureum-N gehaltes (inclusief de al aanwezige $\mathrm{NH} 4-\mathrm{N}$ ) van de verse urine gevonden van 0,346 (s.e. 0,053). In het model wordt het $\mathrm{NH4-}$ $\mathrm{N}$ gehalte van de urineplassen daarom als volgt berekend:

$U_{N H 4 N}=0,346 \cdot U_{\text {ureum }-N}$

Waarin: $U_{\mathrm{NH} 4 \mathrm{~N}}$ is het $\mathrm{NH} 4-\mathrm{N}$ gehalte van de urineplassen $(\mathrm{kg} / \mathrm{kg})$

$U_{\text {ureum- } \mathrm{N}}$ is het ureum- $\mathrm{N}$ gehalte van verse urine $(\mathrm{kg} / \mathrm{kg})$

De verhouding tussen het $\mathrm{NH} 4-\mathrm{N}$ gehalte van de urineplassen en het ureum-N gehalte van de verse urine wordt voor een deel bepaald door de emissie van ammoniak uit de urineplassen, voor een deel door de onvolledige omzetting van ureum naar $\mathrm{NH} 4-\mathrm{N}$ (55.4\% s.e. $6.9 \%$ van de ureum was in de vorm van $\mathrm{NH} 4-\mathrm{N}$ ) en voor een deel door de verdamping van water uit de urineplassen.

Het NH4-N gehalte van met urine bevochtigde schuine wanden wordt gelijk verondersteld aan het NH4-N gehalte van urineplassen op de vloer.

Regressieanalyse op de eigen data laat zien dat de $\mathrm{pH}$ van de bulk mest vooral wordt beïnvloed door het ammoniumgehalte, het totaal carbonaatgehalte en het gehalte aan azijnzuur. Met onderstaande relatie kon $87,1 \%$ van de variatie in bulk $\mathrm{pH}$ worden verklaard:

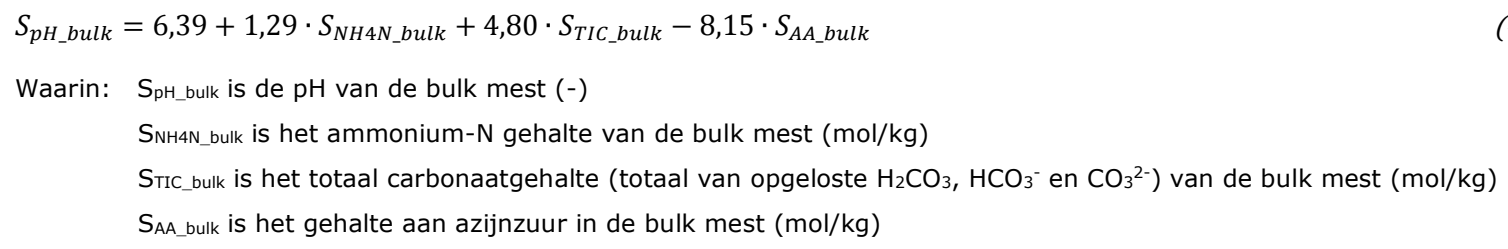


In de rekentool kan het ammoniumgehalte en het gehalte aan azijnzuur uit de hiervoor opgestelde rekenregels worden berekend. Dit geldt niet voor het totaal carbonaatgehalte. Deze is zeer moeilijk modelmatig te berekenen, aangezien het totaal carbonaatgehalte en de pH elkaar wederzijds beïnvloeden. Aangezien we de ammoniakemissie vanuit de voersamenstelling willen voorspellen, nemen we in plaats van het gemeten carbonaatgehalte in de mest de hoeveelheid toegevoegde calciumcarbonaat in het voer op in onze regressievergelijking. De volgende regressielijn had de beste fit, met een $\mathrm{R}^{2}$ van 0,57 (57\% verklaarde variatie):

$S_{\text {pH_bulk }}=6,69+2,79 \cdot S_{N_{4} 4 N_{-} b u l k}+3,00 \cdot S_{\text {CaCO }_{-} \text {feed }}-15,0 \cdot S_{\text {AA_bulk }}$

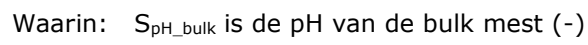

$\mathrm{S}_{\mathrm{NH} 4 \mathrm{~N} \_b u l k}$ is het ammonium-N gehalte van de bulk mest $(\mathrm{mol} / \mathrm{kg})$

$\mathrm{S}_{\mathrm{CaCO}}{ }_{-}$feed is het gehalte aan toegevoegde calciumcarbonaat in het voer $(\mathrm{mol} / \mathrm{kg}$ voer)

SAA_bulk is het gehalte aan azijnzuur in de bulk mest $(\mathrm{mol} / \mathrm{kg})$

De $\mathrm{pH}$ aan het oppervlak van de emissiebron (urineplas, mengmest in kelder) is niet gelijk aan die van de bulk pH (Aarnink \& Elzing, 1998; Hafner et al., 2013; Husted \& Jo/rgensen, 1991; Olesen \& Sommer, 1993; Petersen et al., 2014). De pH aan het oppervlak wordt beïnvloed door de $\mathrm{pH}$ van de bulk en door de gehalten van ammonium en totaal carbonaat. In dit onderzoek is onder labomstandigheden de relatie vastgelegd tussen deze variabelen en de $\mathrm{pH}$ van de bovenste laag van de mengmest uit de mestkelder. In bijlage 2 wordt de uitgebreide regressielijn weergegeven, waarbij de $\mathrm{pH}$ aan het oppervlak wordt berekend uit de $\mathrm{pH}$, het totaal carbonaatgehalte en het ammoniumgehalte van de bulk mest. Aangezien, zoals hiervoor al aangegeven, het moeilijk is om een nauwkeurige schatting te maken van het totaal carbonaatgehalte van de mest, volstaan we met een simpele regressielijn, die ook in voornoemd labonderzoek is bepaald, om de $\mathrm{pH}$ van het oppervlak te berekenen uit de $\mathrm{pH}$ van de bulk mest:

$S_{\text {pH_surface }}=5,59+0,346 \cdot S_{p H_{-} b u l k}$

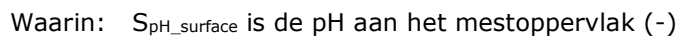

$\mathrm{S}_{\text {pH_bulk }}$ is de $\mathrm{pH}$ van de bulk mest (-)

Uit de analyse van de meetgegevens blijkt dat benzoëzuur de enige (geanalyseerde) voerparameter is met een significant effect op de $\mathrm{pH}$ van verse urine $(\mathrm{P}<0,05 ; 39 \%$ verklaarde variatie). Andere geanalyseerde, maar niet significante, voerparameters, waren dEBS ( $\mathrm{Na}+\mathrm{K}-\mathrm{Cl}-\mathrm{S})$ en de hoeveelheid krijt $\left(\mathrm{CaCO}_{3}\right)$ in het voer. Het effect van de concentratie benzoëzuur in het voer op de $\mathrm{pH}$ van de urine, gemeten direct op de vloer, was niet significant $(P=0,14)$. Echter, vanwege de gemeten effecten van benzoëzuur in het voer op de ammoniakemissie (Aarnink et al., 2006a; Aarnink et al., 2008; Murphy et al., 2011), nemen we deze variabele wel op in ons model om de urine-pH te berekenen. De volgende regressielijn werd gevonden tussen het benzoëzuurgehalte van het voer en de gemeten $\mathrm{pH}$ van de urineplassen ( $12 \%$ verklaarde variatie):

$U_{\text {pH_bulk }}=8,34-0,0027 \cdot F_{\text {benzoic_acid }}$

Waarin: $\mathrm{U}_{\mathrm{pH} \_ \text {bulk }}$ is de $\mathrm{pH}$ van de urine op de vloer (-)

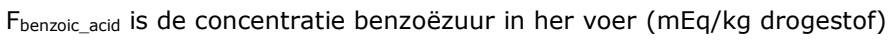

Om de $\mathrm{pH}$ van de urineplas aan het oppervlak te bepalen wordt dezelfde vergelijking gebruikt als voor de mengmest.

Als gevolg van een lagere urease-activiteit op metalen roostervloeren ten opzichte van betonnen roostervloeren (Aarnink \& Elzing, 1998), emitteren deze minder ammoniak. Groenestein e.a. (2014) geven aan dat de emissie vanaf een metalen driekantrooster $1 / 3$ deel is van die van een betonnen roostervloer. Als we uitgaan van een gelijk bevuild oppervlak, betekent dit dat de emissie per $\mathrm{m}^{2} 1 / 3$ deel is van die van een betonnen (rooster)vloer. In het model wordt daarom voor de berekening van de emissie vanaf een metalen roostervloer een correctiefactor van 0,33 toegepast. Voor de betonnen roostervloer wordt verondersteld dat de emissie per $\mathrm{m}^{2}$ bevuild oppervlak gelijk is aan die voor een dichte betonvloer. 


\subsection{Gespeende biggen}

Voor gespeende biggen is grotendeels hetzelfde rekenmodel gebruikt als voor vleesvarkens, zoals dat beschreven is in de voorgaande paragrafen. Er zijn een paar aanpassingen gedaan. De eerste aanpassing is de berekening van het verloop van het gewicht, de voer- en de wateropname. In tegenstelling tot vleesvarkens vlakt de groei bij biggen niet af, maar laat over de gehele periode een exponentiële toename zien. Hetzelfde geldt voor de voer- en wateropname. De volgende curve is daarom gebruikt om deze te beschrijven:

$Y_{t}=A+B \cdot R^{t}$

Waarin: $Y_{\mathrm{t}}$ is het totale gewicht, voeropname, wateropname van het dier op dag t na de start $(\mathrm{kg})$

$A$ is een constante $(\mathrm{kg})$

$B$ is een regressiecoëfficiënt

$\mathrm{R}$ is de acceleratiefactor

$t$ is dagnummer na opleg (dagen)

$R$ is voor het diergewicht, de voer- en wateropname bepaald via regressie op de gemeten data. A en $B$ kunnen vervolgens berekend worden als het begin- en eindgewicht en de totale voer- en wateropname tijdens de opfokperiode bekend zijn. Voor het diergewicht, voer- en drinkwateropname waren de R's respectievelijk 1,057 (s.e. 0.0089 ), 1,059 (s.e. 0.0069)en 1,055 (s.e. 0.0032).

Voor gespeende biggen is tevens de formule voor berekening van de wateraanzet uit de eiwitaanzet aangepast. Als we deze formule zouden toepassen voor biggen dan is er (veel) te weinig verteerd eiwit aanwezig voor de groei van de biggen, vooral bij jonge biggen. We veronderstellen dat de verhouding water-/eiwitaanzet afneemt van 7,0 bij opleg (ca. $8 \mathrm{~kg}$ ) tot 3,4 bij afleveren op 35 dagen na opleg $(23 \mathrm{~kg})$. Hiervoor gebruiken we de volgende formule:

$B_{W / P}=3-\frac{3}{35} \cdot$ Dagnr $+1,11 \cdot 4,77 W^{-0,141}$

Waarin: $B_{W / P}$ is de verhouding tussen water- en eiwitaanzet (-)

Dagnr is dagen na opleg in biggenafdeling op 4 weken leeftijd (dagen)

$\mathrm{W}$ is gewicht $(\mathrm{kg})$

Het aandeel latente warmteafgifte in de totale warmteafgifte (=warmteproductie) is voor biggen anders dan voor vleesvarkens. In de formule bij vleesvarkens wordt het aandeel latente warmteafgifte van de totale warmteafgifte berekend uit de omgevingstemperatuur. Dit is een exponentiële curve. Bij biggen schuiven we deze exponentiële curve naar rechts, zodat het aandeel latente warmteafgifte pas bij hogere temperaturen toeneemt in vergelijking tot vleesvarkens. Bij vleesvarkens van ca. $65 \mathrm{~kg}$ en bij een RV van $65 \%$ nam de ademhalingsfrequentie toe bij een temperatuur van $22,5^{\circ} \mathrm{C}$ (Huynh et al., 2005). Tussen lichte en zware vleesvarkens vonden Aarnink et al. (Aarnink et al., 2006b) een verschil in knikpunt temperatuur waarbij bevuiling van het hok optrad van $5^{\circ} \mathrm{C}$. Deze knikpunten worden gezien als de bovengrens van de comfortzone. Het moment waarop de ademhalingsfrequentie toeneemt ligt iets boven deze comfortzone. We nemen aan dat het verschil tussen een gemiddeld vleesvarken en een gemiddeld gespeende big ook $5^{\circ} \mathrm{C}$ is voor wat betreft het moment dat de ademhalingsfrequentie toeneemt. Tegen deze achtergrond hebben we de volgende formule opgesteld voor berekening van het aandeel latente warmteafgifte bij gespeende biggen:

$f_{Q l-a n i m a l}=0,10+3,54 \cdot 10^{-7} \cdot(T i-5)^{4}$

Waarin: $f_{\mathrm{Ql}-\text {-animal }}$ is het aandeel latente warmteafgifte van de totale warmteafgifte (=totale warmteproductie) (-) $\mathrm{Ti}$ is de omgevingstemperatuur van het dier (staltemperatuur) $\left({ }^{\circ} \mathrm{C}\right)$

bkevap is voor gespeende biggen gefit op de gemeten waterverdamping in de biggenafdelingen met behulp van de kleinste kwadratenmethode (stappen van 0,01). De beste fit werd verkregen bij $b_{k e v a p}=$ 6.22 . 
Het aandeel van de som van ureum-N en NH4-N in de totale $\mathrm{N}$-uitscheiding in de verse urine (de rest zijn andere $\mathrm{N}$-verbindingen) wordt voor gespeende biggen met de volgende formule berekend:

$U_{N H 4 N-p o t}=-9,7 \cdot 10^{-4}+0,77 \cdot U_{N t o t}$

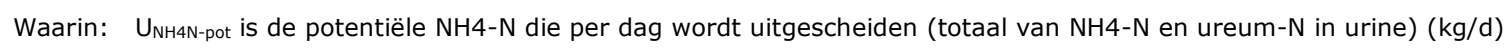
$\mathrm{U}_{\text {Ntot }}$ is de totale hoeveelheid uitgescheiden $\mathrm{N}$ in urine $(\mathrm{kg} / \mathrm{d})$

Voor biggen gaan we in het huidige model uit van een maximale eiwitaanzet van $140 \mathrm{~g} / \mathrm{d}$. Uit de metingen blijkt dat bij gespeende biggen $17,7 \%$ (s.e. 2,0\%) van de feces-N aanwezig is in de vorm van $\mathrm{NH} 4-\mathrm{N}$.

De oppervlaktetemperatuur van de mest kon als volgt worden berekend uit de temperatuur van de uitgaande lucht:

$T_{\text {surface_manure }}=0,851 \cdot T_{\text {exhaust }}$

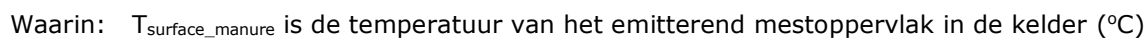

$\mathrm{T}_{\text {exhaust }}$ is de temperatuur van de uitgaande stallucht $\left({ }^{\circ} \mathrm{C}\right)$

Met deze regressielijn kon 32\% van de variatie in de gemeten oppervlaktetemperatuur van de mest in de kelder worden verklaard. De constante, zoals opgenomen bij vleesvarkens, verschilde niet significant van 0 en is daarom niet opgenomen in de vergelijking. De regressielijn voor de oppervlaktetemperatuur van de urineplassen ( $T_{\text {surface_floor }}$ ) was vergelijkbaar met die voor de oppervlaktetemperatuur van de mest. De constante verschilde niet significant van 0 en de regressiecoëfficiënt was 0,867 (s.e. 0,013)).

\subsection{Drachtige zeugen}

Voor drachtige zeugen is ook grotendeels hetzelfde rekenmodel gebruikt als voor vleesvarkens. Net als bij gespeende biggen zijn ook hier enkele aanpassingen gedaan. In tegenstelling tot vleesvarkens en gespeende biggen zijn we bij de drachtige zeugen uitgegaan van een constante groei. Als het beginen eindgewicht van de zeugen bekend is kan de dagelijkse groei worden berekend door het verschil in eind- en begingewicht te delen door het aantal dagen tussen het eind en het begin. Voor de voeropname wordt uitgegaan van het voerschema dat de varkenshouder hanteert. De meeste varkenshouders hebben min of meer een vast voerschema voor drachtige zeugen. De drinkwateropname is gerelateerd aan de voeropname en aan het stadium van de dracht. Uit regressie op de eigen data werd de volgende polynome relatie gevonden tussen de water:voer verhouding en het dagnummer na opleg van de drachtige zeugen in de drachtige zeugen afdeling (ongeveer 10 dagen na spenen)

$W t o F=8,82 \cdot 10^{-8} t^{4}-1,62 \cdot 10^{-5} t^{3}+7,51 \cdot 10^{-4} t^{2}-8,4 \cdot 10^{-3} t+3,31$

Waarin: WtoF is de water:voer verhouding $(\mathrm{kg} / \mathrm{kg})$

$\mathrm{t}$ is dagen na opleg (dagen)

Deze vergelijking laat gedurende de eerste 60 dagen een vrij constante water:voer verhouding zien waarna deze afneemt tot ca. dag 90. Daarna blijft deze weer redelijk constant.

De benodigde metabolische energie voor onderhoud werd voor zeugen als volgt berekend (Noblet et al., 1997):

$M E_{m}=0,420 \cdot W^{0,75}$

Waarin: $M E_{m}$ is metaboliseerbare energie voor onderhoud $(M J / d)$

$W$ is diergewicht $(\mathrm{kg})$

De aanzet van eiwit, vet en water bij de drachtige zeug is vrij ingewikkeld en er is niet veel over bekend. In het begin van de dracht moet de zeug vooral herstellen van de zoogperiode, dit betekent aanzet van spieren en vet voor het eigen lichaam, terwijl in de tweede helft van de drachtperiode de 
aanzet vooral bestaat uit groei van de ongeboren biggen en van het uier (Noblet et al., 1997). In het huidige model hebben we de rekenregels voor berekening van de verschillende aanzetten gelijk gehouden aan die voor vleesvarkens. Alleen de maximale eiwitaanzet is verlaagd naar $100 \mathrm{~g} / \mathrm{d}$. Voor berekening van de latente warmteafgifte zijn voor zeugen ook dezelfde formules aangehouden als voor vleesvarkens.

Het aandeel van de som van ureum- $\mathrm{N}$ en $\mathrm{NH} 4-\mathrm{N}$ in de totale $\mathrm{N}$-uitscheiding in de verse urine (de rest zijn andere $\mathrm{N}$-verbindingen) is bij zeugen gelijk gehouden aan die voor vleesvarkens. Voor het dsgehalte van de feces wordt voor zeugen een vast getal gehanteerd: $0,28 \mathrm{~kg} / \mathrm{kg}$. Uit de metingen blijkt dat bij zeugen $16,5 \%$ (s.e. $0,8 \%$ ) van de feces-N aanwezig is in de vorm van $\mathrm{NH} 4-\mathrm{N}$. Voor zeugen is er van uitgegaan dat er geen $\mathrm{P}$ en Ca wordt vastgelegd. Voor $\mathrm{K}$ wordt dezelfde formule gebruikt als voor vleesvarkens en biggen.

Bij zeugen werd bij de metingen geen verschil gevonden tussen het NH4-N gehalte van de bulk mest en van de bovenlaag van de mest, daarom is het $\mathrm{NH} 4-\mathrm{N}$ gehalte gelijk gesteld aan die van de bulk mest. Er kon geen relatie worden vastgesteld tussen de temperatuur van de uitgaande lucht en de oppervlaktetemperatuur van de mest. Deze temperatuur was vrij constant gedurende de gehele meetperiode, maar verschilde wel duidelijk tussen de beide afdelingen. In afdeling 1 (proefafdeling) was de gemiddelde oppervlaktetemperatuur van de mest $16,5^{\circ} \mathrm{C}$ (s.e. 0,$36 ; n=4$ ) en in afdeling 2 (controleafdeling) was deze gemiddeld 18,6 (s.e. 0,$37 ; n=4$ ). De oppervlaktetemperatuur van de urineplassen ( $T_{\text {surface_floor }}$ ) was wel gerelateerd aan de temperatuur van de uitgaande lucht. De volgende regressielijn verklaarde $50 \%$ van de variatie:

$T_{\text {surface_floor }}=-28,0+2,13 \cdot T_{\text {exhaust }}$

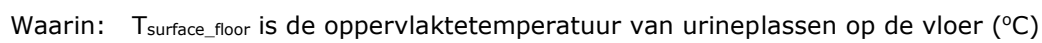

Texhaust is de temperatuur van de uitgaande stallucht $\left({ }^{\circ} \mathrm{C}\right)$

$b_{\text {kevap }}$ is voor de drachtige zeugen gefit op de gemeten waterverdamping in de afdelingen met behulp van de kleinste kwadratenmethode (stappen van 0,01). De beste fit werd verkregen bij $b_{\text {kevap }}=7.00$. 


\section{Materiaal en methode}

Om de rekentool te kunnen valideren is een onderzoek uitgevoerd waarin het effect van voermaatregelen op de urine- en mestsamenstelling en de ammoniakemissie is gemeten bij vleesvarkens, gespeende biggen en drachtige zeugen.

\subsection{Proeflocatie en proefomvang}

Het onderzoek is uitgevoerd op Varkens Innovatie Centrum (VIC) Sterksel in de periode december 2014 tot en met juni 2015 met in totaal 84 drachtige zeugen van het kruisingstype (NL x Y) zeug en met 768 gespeende biggen en 576 vleesvarkens van het kruisingstype Tempo-beer $x(\mathrm{NL} * \mathrm{Y})$ zeug.

\subsection{Proefbehandelingen}

Bij de gespeende biggen en vleesvarkens zijn vier behandelingen met elkaar vergeleken en bij de drachtige zeugen twee behandelingen. De behandelingen zagen er als volgt uit:

- Vleesvarkens:

1. Controle voer (Controle): standaard eiwitgehalte en geen verzurende componenten toegevoegd;

2. Verlaagd eiwit (Eiwit): verlaagd eiwitgehalte $(20 \mathrm{~g} / \mathrm{kg}$ lager);

3. Verzurende werking (Zuur): toevoeging van benzoëzuur $(10 \mathrm{~g} / \mathrm{kg}$; merknaam 'VevoVitall') i.c.m. vervanging van $\mathrm{CaCO} 3$ door Ca-formiaat, voor een verzurende werking op de mest;

4. Verlaagd eiwit en verzurende werking (Combi): combinatie van de behandelingen verlaagd eiwit en verzurende werking.

- Gespeende biggen:

1. Controle voer (Controle): standaard eiwitgehalte en geen verzurende componenten toegevoegd;

2. Verlaagd eiwit (Eiwit): verlaagd eiwitgehalte $(20 \mathrm{~g} / \mathrm{kg}$ lager);

3. Verzurende werking (Zuur): toevoeging van benzoëzuur ( $5 \mathrm{~g} / \mathrm{kg}$; merknaam 'VevoVitall') i.c.m. vervanging van $\mathrm{CaCO}_{3}$ door Ca-formiaat, voor een verzurende werking op de mest;

4. Verlaagd eiwit en verzurende werking (Combi): combinatie van de behandelingen verlaagd eiwit en verzurende werking.

- Drachtige zeugen:

1. Controle voer (Controle): standaard eiwitgehalte en geen verzurende componenten toegevoegd;

2. Proefvoer (Proef): verlaagd eiwitgehalte ( $15 \mathrm{~g} / \mathrm{kg}$ lager), verhoogd NSP-gehalte en $\mathrm{CaCO}_{3}$ was vervangen door Ca-formiaat.

Bij de vleesvarkens is één ronde gedraaid in 4 afdelingen ( 1 behandeling per afdeling). Omdat vier afdelingen (is 576 vleesvarkens) niet tegelijkertijd opgelegd konden worden, zijn de vleesvarkens per 2 afdelingen tegelijk opgelegd, met een interval van 3 weken. Bij de gespeende biggen zijn 2 ronden in 4 afdelingen gedraaid. De vier afdelingen ( 1 behandeling per afdeling) zijn tegelijkertijd opgelegd. Zes weken later is ronde 2 opgelegd. Bij de drachtige zeugen is 1 ronde gedraaid in 2 afdelingen ( 1 behandeling per afdeling). De twee afdelingen zijn drie weken na elkaar opgelegd. In onderstaande tabel is de opleg van de dieren schematisch weergegeven. 
Tabel 4

Oplegschema van de varkens in de verschillende afdelingen in het onderzoek en de toegekende behandelingen.

\begin{tabular}{|c|c|c|c|c|c|}
\hline Diercategorie & Ronde & Afdelingen & $\begin{array}{l}\text { Proef- } \\
\text { handeling }\end{array}$ & Start in & Einde in \\
\hline Vleesvarkens & 1 & 11 en 12 & 1,4 & Wk 48-2014 & Wk 13-2015 \\
\hline Vleesvarkens & 1 & 9 en 10 & 3,2 & Wk 51-2014 & Wk 16-2015 \\
\hline Biggen & 1 & B6, B7, B8, B9 & $2,3,1,4$ & Wk 12-2015 & Wk 17-2015 \\
\hline Drachtige zeugen & 1 & D4B & 1 & Wk 4-2015 & Wk 19-2015 \\
\hline Drachtige zeugen & 1 & D4A & 2 & Wk 7-2015 & Wk 22- 2015 \\
\hline
\end{tabular}

\subsection{Proefopzet en proefindeling}

De proefbehandelingen werden op afdelingsniveau toegepast, aangezien de ammoniakemissie op afdelingsniveau wordt gemeten. Alle dieren binnen een afdeling kregen daarom dezelfde proefbehandeling.

\section{Vleesvarkens}

Eén dag voor opleg in de vleesvarkensstal zijn de beschikbare vleesbiggen individueel gewogen en ingedeeld voor de proef op basis van geslacht, gewicht en leeftijd. Dieren met zichtbare afwijkingen en zieke dieren zijn niet ingedeeld. In week 48 zijn behandeling 1 en 4 opgelegd en in week 51 behandeling 2 en 3. Per oplegweek is gebruik gemaakt van een blokkenindeling. Een blok bestond uit 6 hokken. De dieren binnen een blok waren zo vergelijkbaar mogelijk wat betreft leeftijd en gewicht. Per oplegweek werden vier gewichtsblokken (een licht, middellicht, middelzwaar en zwaar gewichtsblok) van zes hokken gemaakt. Drie hokken uit elk gewichtsblok werden opgelegd in de ene afdeling en drie hokken in de andere afdeling. Per hok werden zes beren en zes gelten opgelegd.

\section{Gespeende biggen}

De biggen zijn op een leeftijd van circa 4 weken gespeend en verplaatst naar de biggenopfokafdelingen. Eén dag voor spenen zijn biggen individueel gewogen en ingedeeld voor de proef op basis van gewicht. Er is gebruik gemaakt van een blokkenindeling. Een blok bestond uit acht hokken (twee hokken per proefbehandeling). De dieren in een blok waren zo vergelijkbaar mogelijk wat betreft gewicht. Per ronde werden vier gewichtsblokken (een licht, middellicht, middelzwaar en zwaar gewichtsblok) van acht hokken gemaakt. De acht hokken binnen een gewichtsblok werden verdeeld over de vier afdelingen (twee hokken per proefbehandeling). Per hok werden zes beren en zes gelten opgelegd.

\section{Drachtige zeugen}

De drachtige zeugen zijn opgelegd in twee identieke drachtafdelingen. Bij opleg in de drachtige zeugenstal (na dekken) is geen indeling gemaakt, omdat vrijwel alle gedekte zeugen in week 4 ingezet werden in de controlegroep en vrijwel alle zeugen in week 7 in de proefgroep. Alleen zeugen die slecht ter been waren en een deel van de pariteit 1 zeugen zijn niet ingezet. In zowel de controlegroep als de proefgroep zijn 41 zeugen opgelegd.

\subsection{Huisvesting en klimaat}

\section{Vleesvarkens}

Het onderzoek is uitgevoerd in vier vleesvarkensafdelingen ( $9 \mathrm{t} / \mathrm{m} \mathrm{12}$ ). Alle afdelingen hadden 2 rijen van 6 hokken aan beide zijden van de voergang. Elk hok had 12 dieren, dus in totaal 144 dieren per afdeling. De hokken waren 2,5 m breed en ca. 5,0 m diep. De vloer bestond, vanaf de controlegang gezien, uit een smal betonrooster, een bolle dichte vloer en een breed metalen driekant rooster. Het 
aandeel dichte vloer in afdeling 9 en 10 was kleiner dan die in 11 en 12 . Voor de plattegronden, dwarsdoorsneden en de exacte maatvoeringen zie figuren 2 en 3 . Alle afdelingen werden mechanisch geventileerd met behulp van ventilatoren op het centrale ventilatiekanaal van de stal. Per afdeling waren twee afvoerkokers met regelkleppen aanwezig. Eén van deze ventilatiekokers was voorzien van een meetventilator. De verse ventilatielucht werd aangevoerd via een kanaal onder de dichte vloer en kwam via de controlegang in de hokken. Het licht was aan van 7.30 tot 16.30 uur. 's Nachts brandde er een controlelamp.
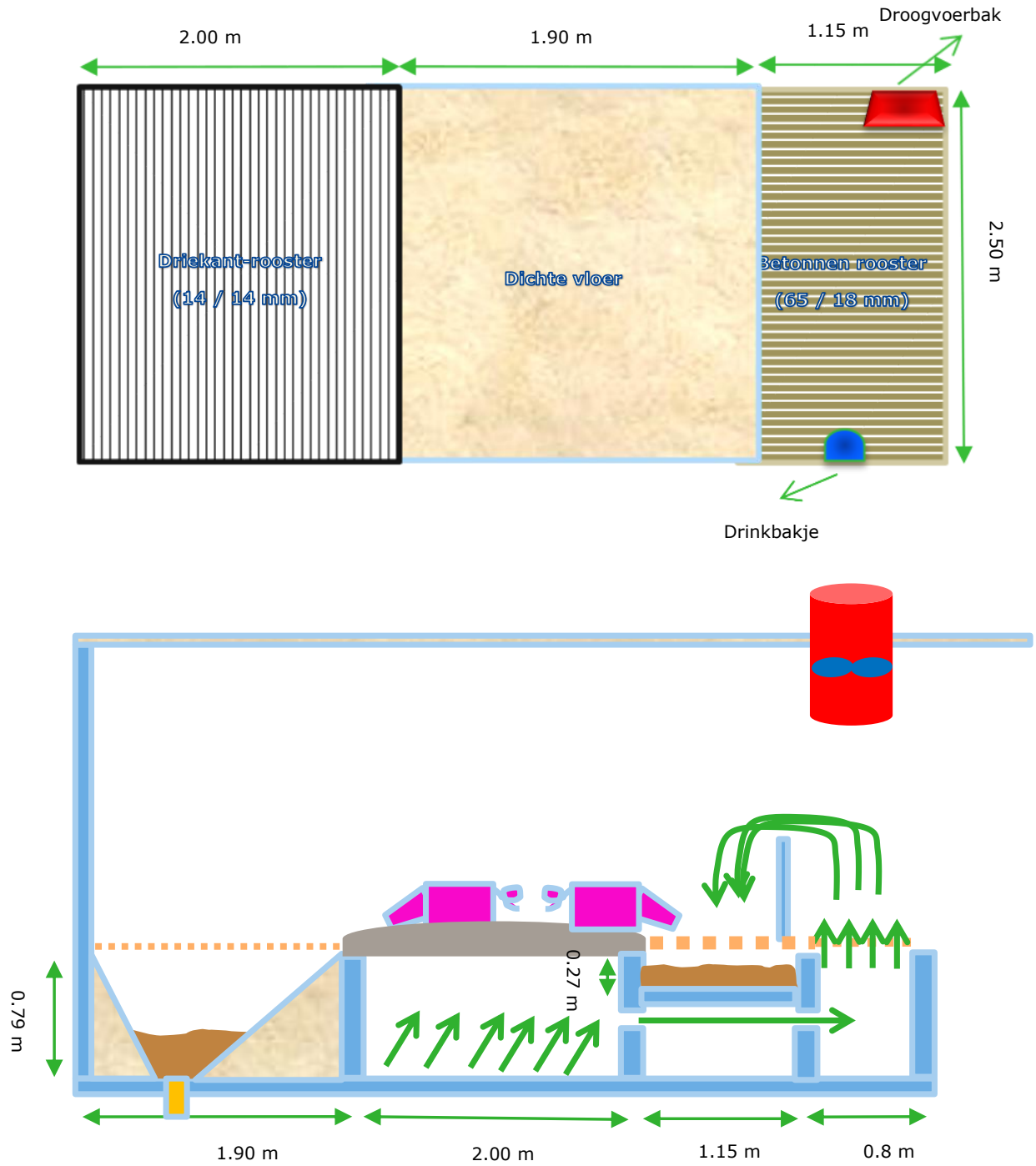

Figuur 2. Plattegrond en doorsnede van de hokken in afdelingen 9 en 10. De pijlen geven het luchtstromingspatroon weer. 


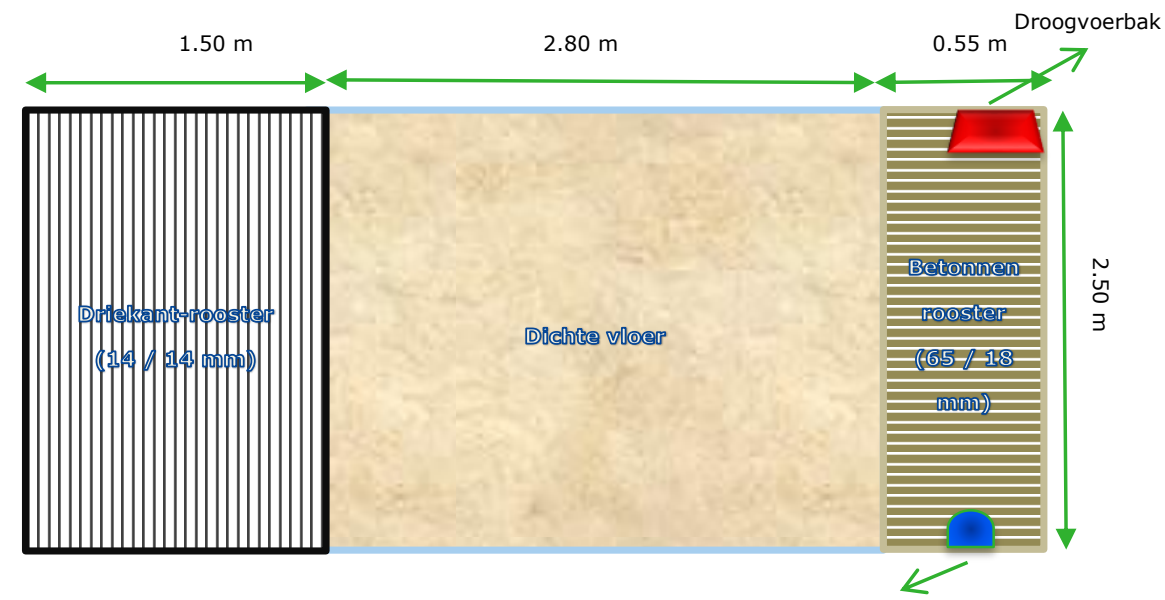

Drinkbakje

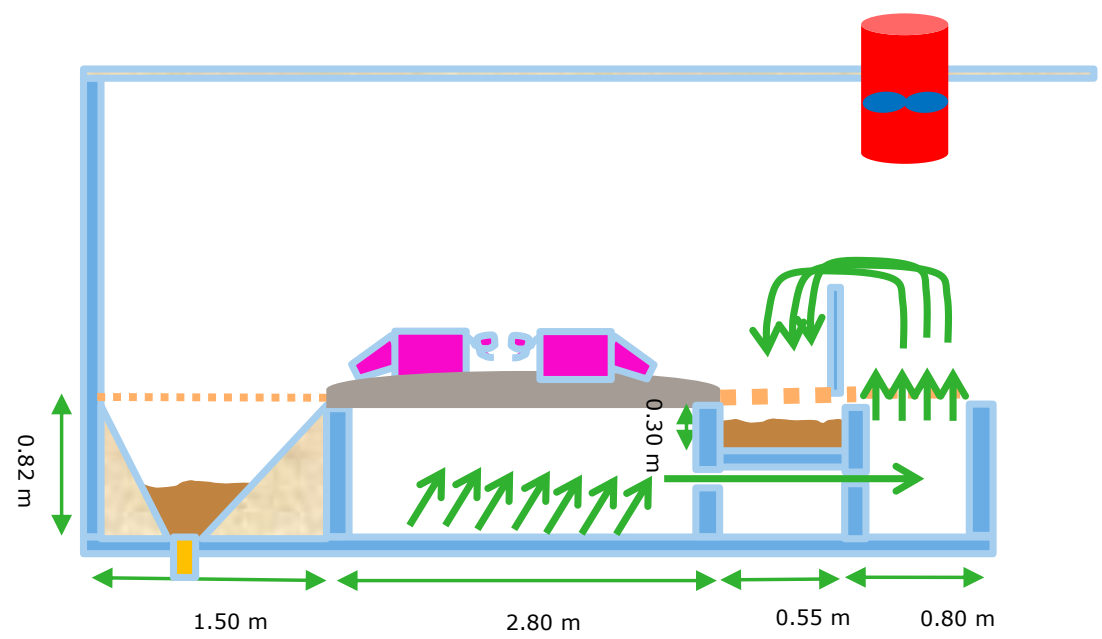

Figuur 3. Plattegrond en doorsnede van de hokken in afdelingen 11 en 12. De pijlen geven het luchtstromingspatroon weer.

\section{Gespeende biggen}

Het onderzoek is uitgevoerd in vier biggenopfokafdelingen. Alle afdelingen hadden 8 hokken voor 12 dieren (4 hokken aan beide zijden van de voergang). De hokken waren 2,20 m diep en 2,40 m breed. De hokken hadden een volledig kunststof roostervloer. Alle afdelingen werden mechanisch geventileerd. De lucht kwam via kokers boven de voergang binnen en werd via een ventilator aan één zijde van de afdeling boven de voergang, op ca. 1,5 m boven de vloer, afgezogen. De eerste 2 dagen was het licht gedurende 24 uur per etmaal aan, zodat de biggen de eetplek goed konden vinden. Daarna was het licht aan van 7.30 uur tot 16.30 uur. Voor een plattegrond van één van de hokken en een dwarsdoorsnede van de afdeling figuur 4.

\section{Drachtige zeugen}

Het onderzoek is uitgevoerd in twee afdelingen voor elk 42 zeugen (afdelingen D4A en D4B). De afdelingen in de drachtstal waren 9,10 m breed en 10,60 m lang. Aan twee zijden van de afdeling lag een dichte betonvloer van 2,00 $\mathrm{m}$ diep. De rest van de vloer bestond uit betonrooster. Het netto leefoppervlak per dier was $2,25 \mathrm{~m}^{2}$. De afdelingen waren uitgerust met een voerstation, dat middenin in het hok op het rooster stond. De drinkbakken waren boven het rooster geplaatst. Er waren vier drinkplaatsen per afdeling. De verse ventilatielucht kwam via grondbuizen en via de roostervloer van de controlegang in de afdeling. Van 7.00 tot 18.00 uur waren de lampen aan in de drachtstal. Voor een plattegrond van één van de hokken en een dwarsdoorsnede van de afdeling figuur 5 . 

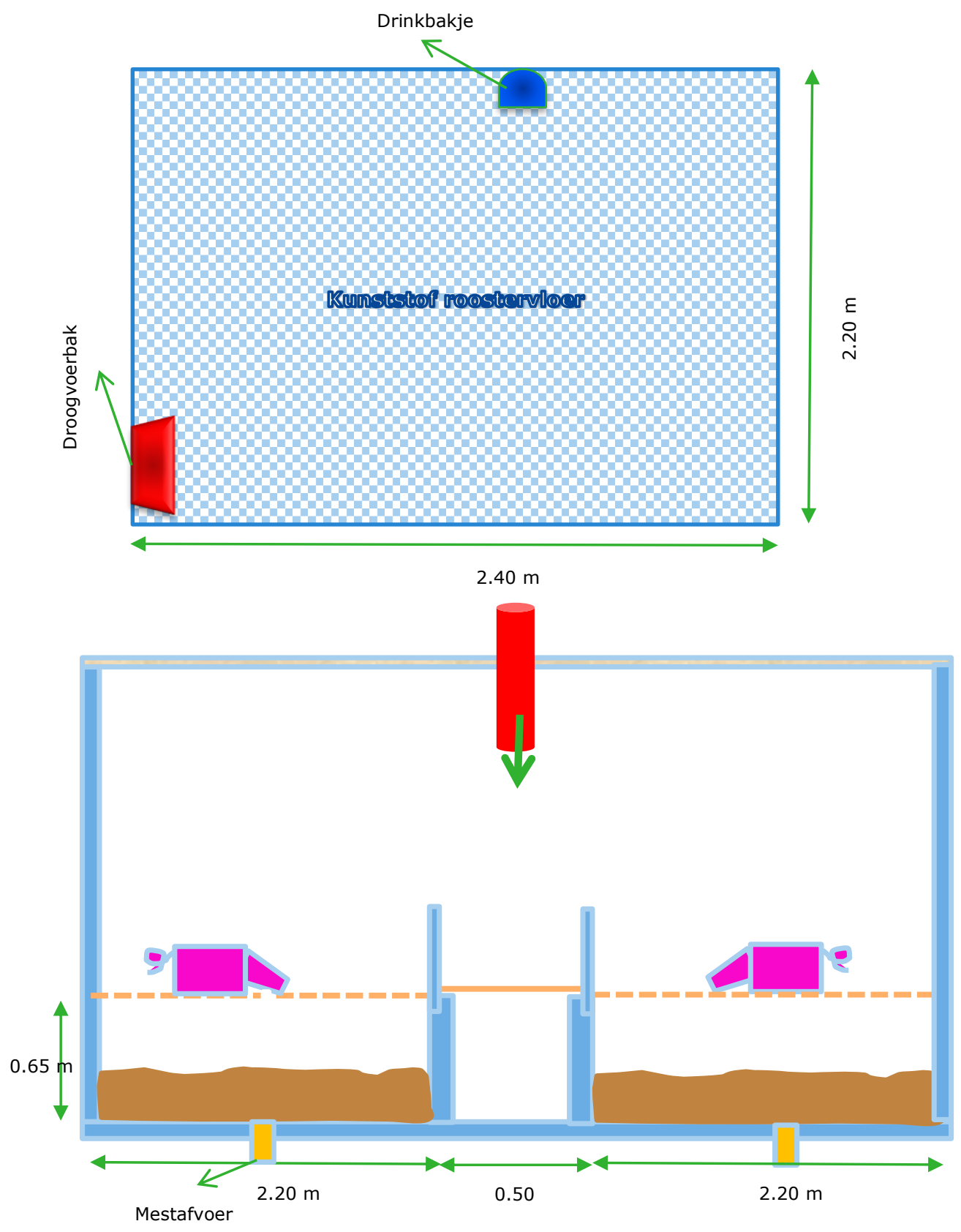

Figuur 4. Plattegrond van één hok en doorsnede van twee hokken in de biggenafdelingen. De pijl geeft de inkomende luchtstroom aan. De lucht werd aan één zijde van de afdeling, boven de voergang, via een ventilator in het plafond op ca. 1,5 m hoogte boven de vloer, afgezogen. 
D4A

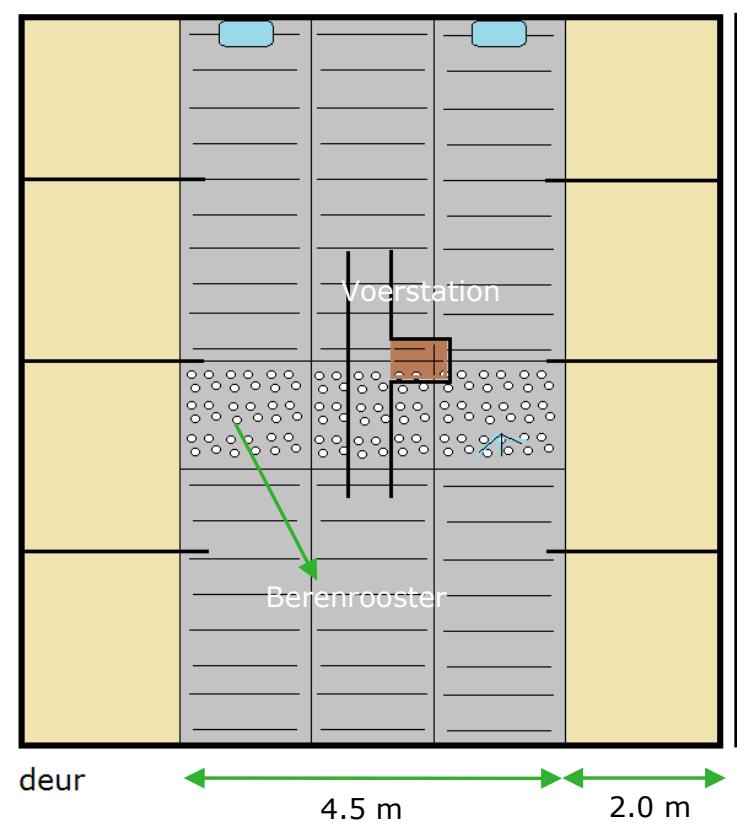

D4B

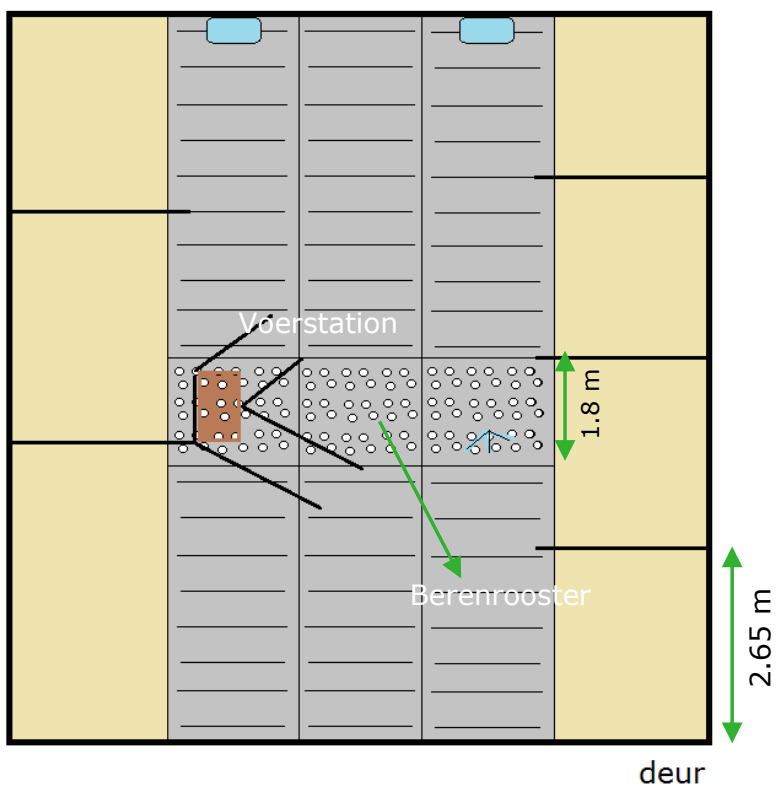

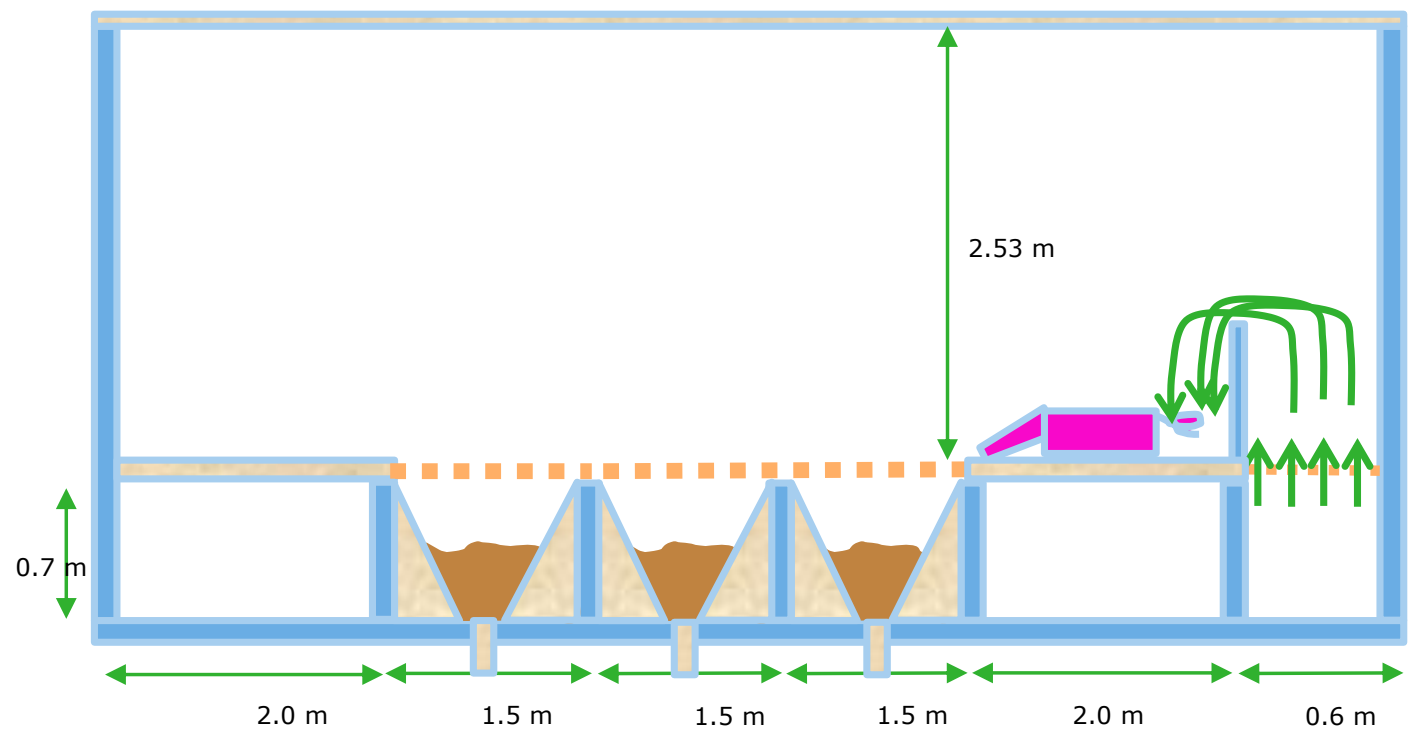

Figuur 5. Plattegrond ( 2 afdelingen) en doorsnede ( $A$ - A plattegrond; 1 afdeling) van de zeugenafdelingen. De controlegang met inlaat van de ventilatielucht via de roostervloer is rechts van beide afdelingen.

\subsection{Voer- en drinkwaterverstrekking}

\section{Vleesvarkens}

Alle vleesvarkens kregen vijf weken startvoer verstrekt. Daarna zijn ze abrupt overgeschakeld op tussenvoer, dat gedurende vier weken is verstrekt. Vervolgens zijn de dieren abrupt overgeschakeld op eindvoer, dat tot afleveren is gevoerd. De vleesvarkens in de vier behandelingen kregen de volgende voeders verstrekt:

1. Controlevoer: startvoer 1 , tussenvoer 1 en eindvoer 1.

2. Verlaagd eiwit: startvoer 2, tussenvoer 2 en eindvoer 2 . Deze voeders bevatten $20 \mathrm{~g} / \mathrm{kg}$ minder eiwit dan de controlevoeders.

3. Verzurende werking: startvoer 3, tussenvoer 3 en eindvoer 3 . Aan deze voeders is $10 \mathrm{~g} / \mathrm{kg}$ benzoëzuur toegevoegd en is een deel van $\mathrm{CaCO}_{3}$ vervangen door Ca-formiaat.

4. Verlaagd eiwit en verzurende werking: startvoer 4 , tussenvoer 4 en eindvoer 4 . Deze voeders bevatten $20 \mathrm{~g} / \mathrm{kg}$ minder dan de controlevoeders, er is $10 \mathrm{~g} / \mathrm{kg}$ benzoëzuur toegevoegd en een deel van $\mathrm{CaCO}_{3}$ is vervangen door Ca-formiaat. 
De grondstoffen- en de berekende en geanalyseerde nutriëntensamenstelling van de voeders is weergegeven in bijlage 3. De vleesvarkens zijn gevoerd via een droogvoerbak met één eetplaats. Tot een gewicht van $70 \mathrm{~kg}$ werden ze onbeperkt gevoerd, daarna werden ze volgens een curve gevoerd. Er mocht maximaal $10 \%$ boven de voercurve gevoerd worden. Drinkwater was in alle hokken onbeperkt beschikbaar via een drinkbakje voor in het hok.

\section{Gespeende biggen}

De gespeende biggen kregen de eerste 16 dagen na spenen een speenvoer verstrekt. Daarna zijn ze abrupt overgeschakeld op biggenopfokkorrel, dat ze tot opleg in de vleesvarkensstal kregen. De gespeende biggen in de vier behandelingen kregen de volgende voeders verstrekt:

1. Controlevoer: speenvoer 1 en biggenopfokkorrel 1.

2. Verlaagd eiwit: speenvoer 2 en biggenopfokkorrel 2. Deze voeders bevatten $20 \mathrm{~g} / \mathrm{kg}$ minder eiwit dan de controlevoeders.

3. Verzurende werking: speenvoer 3 en biggenopfokkorrel 3 . Aan deze voeders is $5 \mathrm{~g} / \mathrm{kg}$ benzoëzuur toegevoegd en is $\mathrm{CaCO}_{3}$ vervangen door Ca-formiaat.

4. Verlaagd eiwit en verzurende werking: speenvoer 4 en biggenopfokkorrel 4. Deze voeders bevatten $20 \mathrm{~g} / \mathrm{kg}$ minder dan de controlevoeders, er is $5 \mathrm{~g} / \mathrm{kg}$ benzoëzuur toegevoegd en $\mathrm{CaCO}_{3}$ is vervangen door Ca-formiaat.

De grondstoffen- en de berekende en geanalyseerde nutriëntensamenstelling van de voeders is weergegeven in bijlage 4. De gespeende biggen werden onbeperkt gevoerd via tweevaks droogvoerbakken. De eerste drie dagen na spenen werd daarnaast twee keer daags een handje voer uit de eigen droogvoerbak in een extra voerbakje in het hok verstrekt om de voeropname te stimuleren. Drinkwater was in alle hokken onbeperkt beschikbaar via een drinkbakje.

\section{Drachtige zeugen}

De drachtige zeugen werden via een voerstation gevoerd volgens de standaard voercurves van VIC Sterksel (zie tabel 5). Per zeug werd de gewenste hoeveelheid voer ingesteld, op basis van pariteit en conditie van de zeug. De zeugen kregen een controlevoer verstrekt of een proefvoer. Het proefvoer bevatte $15 \mathrm{~g} / \mathrm{kg}$ minder eiwit, $29 \mathrm{~g} / \mathrm{kg}$ meer VNSP en $\mathrm{CaCO}_{3}$ was vervangen door Ca-formiaat. De grondstoffen- en de berekende en geanalyseerde nutriëntensamenstelling van de voeders is weergegeven in bijlage 5. Drinkwater was in beide afdelingen onbeperkt beschikbaar via drinknippels (en in de voertrog van het voerstation).

\section{Tabel 5}

Standaard voercurve ( $\mathrm{kg} /$ dag per zeug) voor de drachtige zeugen in het onderzoek.

\begin{tabular}{ccccccc} 
& \multicolumn{2}{c}{ gelt } & & & zeug \\
& mager & normaal & vet & mager & normaal & vet \\
\hline dag $0-40$ & 2,7 & 2,5 & 2,4 & 3,1 & 2,85 & 2,8 \\
\hline dag $40-75$ & 2,5 & 2,5 & 2,4 & 2,9 & 2,7 & 2,7 \\
\hline dag 75-105 & 2,9 & 2,8 & 2,8 & 3,1 & 3,0 & 3,0 \\
\hline
\end{tabular}

\subsection{Afleverstrategie}

Bij levering van de varkens naar het slachthuis is gestreefd naar een gemiddeld geslacht gewicht van circa $93 \mathrm{~kg}$ voor zowel de beren als de zeugjes met een spreiding die is toegestaan binnen het gewichtstraject van het concept waarin ze geleverd worden (dit is zo vergelijkbaar mogelijk met de praktijk). Dit betekende voor de zeugjes een geslacht gewicht tussen de 82 en $103 \mathrm{~kg}$, en voor de beren tussen de 80 en $100 \mathrm{~kg}$. De varkens zijn nuchter geleverd. De dieren in een afdeling zijn in maximaal twee keer geleverd. 


\subsection{Metingen en waarnemingen}

Tijdens het onderzoek zijn de volgende gegevens verzameld:

\section{Technische resultaten:}

- Gewicht: alle vleesvarkens, biggen en zeugen zijn bij de start van het onderzoek (bij opleg) en aan het eind (dag voor leveren naar het slachthuis of dag van verplaatsen uit de afdeling) gewogen. Daarnaast zijn bij de vleesvarkens en de gespeende biggen, bij elke voeromschakeling 4 hokken per afdeling gewogen. Dit waren hokken met een gemiddeld opleggewicht ( 2 hokken links en 2 hokken rechts van de voergang). Steeds werden dezelfde hokken gewogen.

- Voeropname op hokniveau van de gespeende biggen en de vleesvarkens. Dit is vastgelegd per voersoort. De voeropname per hok is bijgehouden door wekelijks het voertotaal uit de voercomputer te noteren. De hoeveelheid voer die nog in de voerbak zat is met een peilstok bepaald en van de verstrekte hoeveelheid voer afgetrokken. Daarnaast is de voeropname per hok vastgelegd bij elke weging van de dieren en bij uitval van een dier.

- Voeropname per zeug: de voeropname van de drachtige zeugen is bijgehouden door wekelijks de verstrekte hoeveelheid voer per zeug uit de voercomputer op te schrijven. Voor de start van het onderzoek en aan het einde van het onderzoek is de voergift van het voerstation geijkt.

- Bij veterinaire behandeling van een dier zijn de datum en de reden van behandeling vastgelegd.

- Bij uitval van een dier zijn de datum, het gewicht (biggen en vleesvarkens), de mogelijke doodsoorzaak en de voeropname tot dan toe geregistreerd.

- Overige bijzonderheden zijn vastgelegd in een logboek.

- Slachtgegevens: slachtgewicht, vleespercentage, spier- en spekdikte, karkas- en orgaanbemerkingen.

- Voermonsters: éénmaal per week is per afdeling een voermonster genomen uit de droogvoerbakken. Deze monsters zijn in de vriezer bewaard bij -20 graden Celsius. Monsters van dezelfde voeders zijn voor de analyse gepoold en geanalyseerd op ruw eiwit, ruw vet, ruwe celstof, ruw as, suiker, zetmeel, $\mathrm{Ca}, \mathrm{Na}, \mathrm{K}, \mathrm{Cl}$, sulfaat, benzoëzuur en mierenzuur.

Ammoniak en klimaat:

- Ammoniakconcentratie. Continue meting van de ammoniakconcentraties van de in- en uitgaande afdelingslucht met behulp van een NOx monitor (Ogink et al., 2013).

- Ventilatiedebiet. Continue meting van het ventilatiedebiet met meetventilatoren. Elke meetventilator is geijkt met een referentie-meetventilator. Op basis van deze ijking zijn ijklijnen gemaakt per meetventilator tussen gelogde en werkelijke ventilatiehoeveelheden. De gelogde ventilatiehoeveelheden zijn gecorrigeerd met deze ijklijnen.

- Temperatuur / Relatieve luchtvochtigheid. Continue meting van T/RV van uitgaande stallucht en inkomende buitenlucht (Escort T/RV loggers).

- Oppervlaktetemperatuur vloer. Tijdens dagen van mest aflaten (zie hierna) is de oppervlaktetemperatuur van de bevuilde (rooster)vloeren op tenminste 10 plekken (met de Raynger ST ProPlus van Raytek, Santa Cruz, vS) gemeten.

- Oppervlaktetemperatuur mest in mestkelder. Tijdens dagen van mest aflaten (zie hierna) is de oppervlakte-temperatuur van de mest in de mestkelder op tenminste 10 plekken gemeten (met de Raynger ST ProPlus van Raytek, Santa Cruz, VS).

- Luchtsnelheid. Tijdens dagen van mest aflaten (zie hierna) is de luchtsnelheid over het met urine bevuilde (rooster)vloer oppervlak met een hittedraad luchtsnelheidsmeter gemeten. Indien roosters gemakkelijk konden worden verwijderd (bij gespeende biggen en vleesvarkens) is tevens de luchtsnelheid over het emitterend mestoppervlak in de mestkelder gemeten.

Metingen urine, feces en mest:

De monsternames van urine, feces en bovenste laag mest en de verschillende metingen aan urineplassen en aan de mengmest zijn steeds gedaan op dezelfde dag als het aflaten van de mest uit de mestkelder. Het mengmestmonster is steeds tijdens het aflaten van de mest genomen. Voor een overzicht van de momenten van mestaflaten zie bijlage 6 . Bij vleesvarkens is de mest tijdens de ronde 4 maal afgelaten. Bij afdelingen 11 en 12 werd de mest de eerste keer afgelaten op dag 33 na opleg en op dezelfde kalenderdatum werd tevens de mest afgelaten bij afdelingen 9 en 10, op dag 12 na opleg. Vervolgens werd dit na 3, 6 en 9 weken herhaald. Bij de biggen werd de mest in alle afdelingen 
afgelaten op dag 13 en op dag 27 na opleg, in beide ronden. Bij de zeugen werd de mest tijdens de ronde 4 maal afgelaten. Bij controle-afdeling (D4B) werd de mest de eerste keer afgelaten op dag 33 na opleg en op dezelfde kalenderdatum werd tevens de mest afgelaten bij de proefafdeling (D4A), op dag 12 na opleg. Vervolgens werd dit na 3, 6 en 9 weken herhaald.

- Monsters urine en feces. Tijdens dagen van mest aflaten zijn enkelvoudige urine- en fecesmonsters van tenminste 12 dieren per monster genomen. De monsters van elk dier zijn in eerste instantie apart gehouden. Van elk urinemonster werd met een pipet ca. $2 \mathrm{ml}$ in een potje met zuur gedaan om de ureumomzetting naar ammonium te stoppen. Uiteindelijk zat in dit potje met zuur 2 $\mathrm{ml}$ urine van elk van de 12 dieren. In de resterende urine werd de $\mathrm{pH}$ ter plekke bepaald. In het lab werden de urinemonsters zonder zuur op gelijke massa-basis samengevoegd en geanalyseerd op NH4-N, N-totaal en Kalium. Bij deze urine-monsters werd de ureum voor de NH4-N analyse eerst omgezet door toevoeging van urease. De urinemonsters met zuur werden geanalyseerd op NH4-N. De feces monsters werden eveneens op gelijke massa-basis samengevoegd en geanalyseerd op NH4-N, N-totaal en Kalium.

- Monsters urineplassen. Tijdens dagen van mest aflaten is het ammoniumgehalte en de $\mathrm{pH}$ van urineplassen bepaald via de 'filtermethode'. Hiervoor werden 5 monsters op representatieve plekken in het hok genomen. Representatief wil zeggen dat de vloermonsters werden genomen van plekken die veel bevuild zijn. Monsters werden genomen door de urine op bevuilde plekken op te zuigen in filters (glasvezelfilters). Op elke monsterplek werden 2 filters vol gezogen met urine. Hierbij ging het ene filter in een potje met zuur en het andere filter in een potje met water. Tien filters, die verspreid over de afdeling waren genomen, werden samengevoegd tot één verzamelmonster in het potje met zuur en één verzamelmonster in het potje met water. Door de filters in het zuur te leggen werd de omzetting van ureum naar ammonium gestopt. Na goed mengen werd de $\mathrm{pH}$ ter plekke gemeten in het potje met filters in water. In het chemisch lab werden de potjes met filters in water geanalyseerd op NH4-N en Kalium gehalte. Hierbij werd er voor gezorgd dat alle ureum was omgezet naar ammonium (toevoeging urease).

- Monsters bovenste laag mest in kelder. Tijdens dagen van mest aflaten zijn enkelvoudige verzamelmonsters van de bovenste laag mest in de mestkelder via de 'filtermethode' (absorptiemonsters van de bovenste laag mest) genomen. Hiervoor werden 5 monsters evenredig verspreid over de gehele mestkelder in een hok genomen. Op elke monsterplek werden 2 filters vol gezogen met mest. Hierbij ging het ene filter in een potje met zuur en het andere filter in een potje met water. Monsters van 2 hokken (10 filters) bij vleesvarkens en biggen en monsters verspreid genomen over de verschillende mestkanalen bij zeugen werden samengevoegd tot één verzamelmonster in het potje met zuur en één verzamelmonster in het potje met water. Door de filters in het zuur te leggen werd de omzetting van ureum naar ammonium gestopt. Na goed mengen werd de $\mathrm{pH}$ ter plekke gemeten in de potjes met water. In het chemisch lab werd in het potje met water naast het ammoniumgehalte tevens het gehalte aan Kalium geanalyseerd.

- Monsters mengmest. Tijdens dagen van mest aflaten werd een duplo monster genomen van de mest in de gehele mestkelder. Dit werd gedaan door de uitstromende mest uit de mestkelder te bemonsteren, volgens een vastgestelde procedure (zie bijlage 7). De $\mathrm{pH}$ van de monsters werd direct gemeten. Op het lab in Wageningen werden ds, as, $\mathrm{pH}, \mathrm{NH} 4-\mathrm{N}, \mathrm{N}$-totaal, $\mathrm{K}, \mathrm{Na}, \mathrm{Cl}, \mathrm{P}, \mathrm{Ca}$ en vluchtige vetzuren concentraties bepaald. Op het lab van de Universiteit van Zuid Denemarken (Odense) werd deze mest geanalyseerd op totaal anorganisch koolstof (TIC). Tevens werd de $\mathrm{pH}$ gradiënt in de bovenlaag van de mest in een aantal monsters geanalyseerd.

- Directe $\mathrm{pH}$ meting. Tijdens dagen van mest aflaten werd de $\mathrm{pH}$ van urineplassen ook rechtstreeks gemeten (naast de filtermethode) met een oppervlakte $\mathrm{pH}$-meter (Orion Ross ultra flat surface, waterproof BNC, 1M, Thermo Fischer Scientific, Landsmeer). Tevens werd bij vleesvarkens en biggen de oppervlakte-pH van de mengmest gemeten in de mestkelder, op 0,5 cm en $5 \mathrm{~cm}$ diepte bij vleesvarkens en op 0,5 en $2 \mathrm{~cm}$ diepte bij biggen (bij biggen was het mestniveau, zeker bij de $1^{\mathrm{e}}$ keer mestaflaten, vaak niet hoger dan een paar $\mathrm{cm}$ ). Alle $\mathrm{pH}$ metingen op locatie zijn gedaan met het type $\mathrm{pH}$ meter, zoals hierboven genoemd.

- Mestvolume. Elke week, gelijktijdig met de bepaling van de voer- en wateropname van de afgelopen week, werd het mestniveau in alle mestkanalen vastgelegd met een peilstok. Het mestniveau werd op 3 plekken per kanaal vastgesteld (voor, midden en achterin de afdeling). 


\section{Overige metingen en waarnemingen:}

- Hokbevuiling. Vier maal per week, 2x 's morgens en 2x 's middags, werd de hokbevuiling gescoord. Het aandeel van de vloer dat bevuild was met urine werd visueel bepaald en genoteerd. De dichte vloer en de roostervloer werden hierbij apart gescoord. Bij vleesvarkens werd tevens onderscheid gemaakt tussen bevuiling van de betonnen roostervloer voor in het hok en het metalen driekantrooster achter in het hok. Er werden scores gegeven per onderdeel van het hok, zoals hiervoor aangegeven, van 0 (volledig droog) tot 10 (100\% bevochtigd met urine).

- Bevuiling schuine wanden bij vleesvarkens en zeugen. Verspreid over de ronde is $5 x$ bij de vleesvarkens en $4 x$ bij de zeugen de bevochtiging van de schuine wanden in de mestput met urine gescoord, als percentage van de totale oppervlakte boven het mestniveau. Hiervoor is een looplamp gebruikt om de natte plekken te kunnen onderscheiden.

- Bevuilde keldervloer bij biggen. Bij biggen is voor het mestaflaten beoordeeld of de gehele keldervloer bedekt was met een laag mest. Dit was tijdens de eerste keer aflaten meestal niet het geval.

- Wateropname. Het drinkwaterverbruik werd per afdeling gemeten met behulp van een watermeter. Het waterverbruik werd dagelijks per afdeling automatisch opgeslagen.

Procedure voor het bepalen van de vloeremissie

$\mathrm{Na}$ het aflaten van de mest in de kelder werd deze vol met water gezet (tot ca. $10 \mathrm{~cm}$ onder de roostervloer bij vleesvarkens en zeugen en voor de helft met water bij de gespeende biggen). De procedure in de tijd was als volgt: op dinsdag werd de mest afgelaten en dinsdagmiddag en woensdagmorgen werden de kelders met water gevuld. De emissie op donderdag werd als maat voor de vloeremissie genomen, aangezien de toegevoegde mest in de mestkelder dusdanig verdund werd dat deze als verwaarloosbaar mag worden beschouwd. Op vrijdag werd vervolgens het water met de toegevoegde mest van 2 dagen weer afgelaten.

\subsection{Gegevensverwerking en statistische analyse}

De technische resultaten zijn geanalyseerd met behulp van variantie-analyse (Genstat, 2013).

\section{Vleesvarkens}

De technische kengetallen (groei, voer- en EW-opname, voeder- en EW-conversie), slachtgegevens (slachtgewicht, vleespercentage, spierdikte en spekdikte) van de vleesvarkens zijn geanalyseerd op hokniveau. Het model zag er als volgt uit: $\mathrm{Y}=\mu+$ proefbehandeling + rest

Het berekend eindgewicht is als volgt berekend uit het slachtgewicht (Uniformeringsafspraken Varkenshouderij 2013):

Beren: berekend eindgewicht $=5+$ (slachtgewicht $\times 1,22)$

Gelten: berekend eindgewicht $=5+($ slachtgewicht $\times 1,20)$

Met behulp van de Chi-kwadraat toets is nagegaan of er tussen de behandelingen verschillen bestaan in het aantal uitgevallen dieren, het aantal veterinair behandelde dieren en het aantal dieren per karkas- en orgaanbemerking.

\section{Gespeende biggen}

De groei, voer- en EW-opname, voeder- en EW-conversie van de gespeende biggen zijn op hokniveau geanalyseerd met het volgende model: $Y=\mu+$ ronde + proefbehandeling + rest

Het aantal uitgevallen dieren en veterinair behandelde dieren is geanalyseerd met de chi-kwadraat toets.

\section{Drachtige zeugen}

De voeropname van de zeugen in de drachtstal en het gewicht van de zeugen bij inleg in de drachtstal en bij verplaatsen van de drachtstal naar de kraamstal zijn op zeugniveau geanalyseerd met het volgende model: $Y=\mu+$ proefbehandeling + rest 


\section{Analyse mestsamenstelling en ammoniakemissie}

Het effect van voerbehandeling op de samenstelling van de feces, urine en mengmest en op de hokbevuiling en de ammoniakemissie werd geanalyseerd met de 'Unbalanced Analysis of Variance' procedure van GenStat (Genstat Committee, 2015) met het volgende model voor vleesvarkens:

$Y_{i j k l}=\mu+$ eiwit $_{i}+$ zuur $_{j}+$ blok $_{k}+\varepsilon_{i j k l}$

Waarin: $Y_{i j k l}$ : afhankelijke variabele, $\mu$ : overall gemiddelde, eiwit $;$ : effect van eiwitbehandeling ( $i=$ normaal, verlaagd); zuur $_{j}$ : effect van verzurende werking voer $(j=$ normaal, verzurend $) ;$ blok $_{k}=$ effect van afdelingsblok $(k=$ afd. 11/12, 9/10 bij vleesvarkens; $k=6,7,8,9$ bij biggen); $\varepsilon_{i j k l}$ : restfout.

Bij vleesvarkens kon het interactie-effect tussen de eiwit- en zuurbehandelingen niet meegenomen worden, aangezien deze verstrengeld is met het effect van afdelingsblok. Uit onderzoek van Bakker et al. (Bakker et al., 2005) is gebleken dat de effecten van voermaatregelen die gericht zijn op verlaging van de ammoniakemissie, door verlaging van het eiwitgehalte en verlaging van de $\mathrm{pH}$ van urine en mest, additief zijn en dus geen interactie met elkaar hebben. Bij de gespeende biggen is het interactieeffect daarom ook niet meegenomen in de analyse. Bij gespeende biggen is 'blok' gelijk aan het afdelingseffect. Aangezien bij gespeende biggen 2 ronden zijn gedraaid, met een verschillende behandeling per ronde, kon hier het afdelingseffect worden bepaald. Bij de drachtige zeugen was het voereffect volledig verstrengeld met het afdelingseffect, daarom werd het volgende simpele model gebruikt voor deze analyse:

$Y_{i j}=\mu+$ behandeling $_{i}+\varepsilon_{i j}$

Waarin: $Y_{i j}$ : afhankelijke variabele, $\mu$ : overall gemiddelde, behandeling $g_{i}$ effect van voerbehandeling $(i=$ normaal, combi verlaagd eiwit en vervanging $\mathrm{CaCO}_{3}$ door Ca-formiaat); $\varepsilon_{\mathrm{ij}}$ : restfout.

\section{Modelvalidatie}

Op basis van de verzamelde inputdata voor het model is de ammoniakemissie op afdelings-, vloer- en kelderniveau modelmatig ingeschat. De berekende waarden zijn vergeleken met de gemeten waarden. Hiervoor zijn $Y=X$ grafieken gemaakt en bepaald of de constante en/of de regressiecoëfficiënt significant afwijken van respectievelijk 0 en 1 . Daarnaast is van de verschillen tussen berekende en gemeten waarden de RMSE (Root Means Square Error) berekend. De RMSE wordt berekend met de volgende formule:

$R M S E=\frac{\sqrt{\sum_{1}^{n}\left(V_{\text {berekend_i }}{ }^{\left.-V_{\text {gemeten } \_}\right)^{2}}\right.}}{n}$

Waarin: RMSE: root mean square error; $\mathrm{V}_{\text {berekend }}$ is de berekende waarde van de variabele; $\mathrm{V}_{\text {gemeten }}$ is de gemeten waarde van de variabele; $\mathrm{n}$ is het aantal waarden 


\section{$4 \quad$ Resultaten en discussie}

\subsection{Vleesvarkens}

\subsubsection{Technische resultaten van opleg tot afleveren (alle hokken)}

De technische resultaten van de vleesvarkens van opleg tot afleveren (alle hokken) zijn weergegeven in tabel 6.

\section{Tabel 6}

Technische resultaten van opleg tot afleveren (alle hokken) van vleesvarkens die het controle voer, voer met een verlaagd eiwitgehalte, voer met een verzurende werking of voer met de combinatie verlaagd eiwitgehalte en verzurende werking kregen.

\begin{tabular}{|c|c|c|c|c|c|c|}
\hline & Controle & $\begin{array}{l}\text { Verlaagd } \\
\text { eiwit }\end{array}$ & Verzurend & $\begin{array}{l}\text { Verlaagd eiwit } \\
\text { + verzurend }\end{array}$ & SEM ${ }^{1}$ & war- \\
\hline Aantal dieren & 144 & 144 & 144 & 144 & & \\
\hline Aantal hokken & 12 & 12 & 12 & 12 & & \\
\hline Eindgewicht $(\mathrm{kg})$ & 123,8 & 125,3 & 123,0 & 124,9 & & \\
\hline Aantal dagen & 113,1 & 108,6 & 108,9 & 112,1 & & \\
\hline Groei (g/d) & $876^{a}$ & $922^{\mathrm{b}}$ & $898^{c}$ & $894^{c}$ & 6,0 & $<0,001$ \\
\hline EW-conversie & 2,69 & 2,73 & 2,74 & 2,73 & 0,019 & 0,38 \\
\hline \multicolumn{7}{|c|}{ Op basis van berekend eindgewicht: } \\
\hline $\begin{array}{l}\text { Berekend eindgewicht } \\
(\mathrm{kg})^{2}\end{array}$ & 118,3 & 121,3 & 120,2 & 121,2 & & \\
\hline Groei (g/d) & $828^{a}$ & $885^{\mathrm{b}}$ & $872^{\mathrm{bc}}$ & $860^{c}$ & 5,5 & $<0,001$ \\
\hline Voederconversie & 2,61 & 2,60 & 2,58 & 2,60 & 0,018 & 0,57 \\
\hline EW-conversie & 2,85 & 2,84 & 2,82 & 2,84 & 0,020 & 0,66 \\
\hline
\end{tabular}

${ }^{1}$ SEM = gepoolde standaard error van het gemiddelde (geeft een indicatie van de nauwkeurigheid van de schatting van de gemeten variabele); ${ }^{2}$ Het berekend eindgewicht is als volgt berekend: beren: (slachtgewicht $\left.* 1,22\right)+5 ;$ zeugen: (slachtgewicht $* 1,20)+5 ;$ a,b.c Gemiddelden met een verschillende letter binnen een rij zijn verschillend $(p<0,05)$

Uit tabel 6 blijkt dat de vleesvarkens die het controlevoer kregen minder voer hebben opgenomen en langzamer zijn gegroeid dan de vleesvarkens in de andere drie proefbehandelingen. De vleesvarkens die het verlaagd eiwit voer kregen hebben het meeste voer opgenomen en zijn het snelste gegroeid. De voeropname en groei van de vleesvarkens in de twee andere proefbehandelingen zaten hier tussen in en verschilden niet van elkaar. Er was geen verschil in voederconversie tussen de vier proefbehandelingen.

\subsubsection{Technische resultaten per gewichtstraject}

In vier hokken per proefbehandeling zijn de dieren gewogen bij de overschakeling van startvoer naar tussenvoer en van tussenvoer naar eindvoer. De technische resultaten van deze vleesvarkens tijdens de startvoerfase, de tussenvoerfase, de eindvoerfase en van opleg tot afleveren zijn weergegeven in tabel 7. 
Tabel 7

Technische resultaten per gewichtstraject en van opleg tot afleveren (4 hokken per proefbehandeling) van vleesvarkens die het controle voer, voer met een verlaagd eiwitgehalte, voer met een verzurende werking of voer met een verlaagd eiwitgehalte en een verzurende werking kregen.

\begin{tabular}{|c|c|c|c|c|c|c|}
\hline & Controle & $\begin{array}{c}\text { Verlaagd } \\
\text { eiwit }\end{array}$ & Verzurend & $\begin{array}{l}\text { Verlaagd eiwit } \\
\text { + verzurend }\end{array}$ & SEM $^{1}$ & $\begin{array}{c}\text { P- } \\
\text { waarde }\end{array}$ \\
\hline Aantal dieren & 48 & 48 & 48 & 48 & & \\
\hline Aantal hokken & 4 & 4 & 4 & 4 & & \\
\hline \multicolumn{7}{|l|}{ Startvoerfase: } \\
\hline Opleggewicht (kg) & 24,7 & 25,2 & 25,3 & 24,8 & & \\
\hline Tussengewicht $(\mathrm{kg})$ & 56,4 & 59,2 & 59,0 & 58,4 & & \\
\hline Groei (g/d) & $880^{\mathrm{a}}$ & $945^{b}$ & $936^{b}$ & $933^{b}$ & 13,1 & 0,02 \\
\hline Voeropname $(\mathrm{kg} / \mathrm{d})$ & 1,67 & 1,77 & 1,72 & 1,73 & 0,041 & 0,41 \\
\hline Voederconversie & 1,90 & 1,87 & 1,84 & 1,86 & 0,027 & 0,52 \\
\hline EW-opname (/d) & 1,90 & 2,02 & 1,97 & 1,98 & 0,046 & 0,41 \\
\hline EW-conversie & 2,16 & 2,14 & 2,10 & 2,12 & 0,031 & 0,52 \\
\hline \multicolumn{7}{|l|}{ Tussenvoerfase: } \\
\hline Tussengewicht $(\mathrm{kg})$ & 56,4 & 59,2 & 59,0 & 58,4 & & \\
\hline Tussengewicht $(\mathrm{kg})$ & 78,5 & 86,6 & 85,6 & 79,7 & & \\
\hline Groei $(\mathrm{g} / \mathrm{d})$ & $820^{a}$ & $1013^{b}$ & $985^{b}$ & $788^{\mathrm{a}}$ & 27,4 & $<0,001$ \\
\hline Voeropname $(\mathrm{kg} / \mathrm{d})$ & $2,07^{a}$ & $2,47^{c}$ & $2,42^{\mathrm{bc}}$ & $2,31^{\mathrm{b}}$ & 0,056 & 0,001 \\
\hline Voederconversie & $2,54^{a}$ & $2,44^{\mathrm{a}}$ & $2,46^{a}$ & $2,94^{b}$ & 0,073 & 0,001 \\
\hline EW-opname (/d) & $2,26^{a}$ & $2,70^{c}$ & $2,64^{\mathrm{bc}}$ & $2,51^{\mathrm{b}}$ & 0,061 & 0,001 \\
\hline EW-conversie & $2,77^{a}$ & $2,66^{\mathrm{a}}$ & $2,68^{\mathrm{a}}$ & $3,20^{\mathrm{b}}$ & 0,080 & 0,001 \\
\hline \multicolumn{7}{|l|}{ Eindvoerfase: } \\
\hline Tussengewicht $(\mathrm{kg})$ & 78,5 & 86,6 & 85,6 & 79,7 & & \\
\hline Levend eindgewicht $(\mathrm{kg})$ & 124,2 & 125,5 & 124,1 & 123,8 & & \\
\hline Aantal dagen & 49,6 & 45,6 & 45,5 & 47,8 & & \\
\hline Groei $(\mathrm{g} / \mathrm{d})$ & $922^{\mathrm{a}}$ & $852^{\mathrm{b}}$ & $846^{\mathrm{b}}$ & $922^{\mathrm{a}}$ & 18,7 & 0,02 \\
\hline Voeropname (kg/d) & $2,60^{\mathrm{a}}$ & $2,60^{a}$ & $2,56^{\mathrm{b}}$ & $2,58^{\mathrm{ab}}$ & 0,010 & 0,04 \\
\hline Voederconversie & $2,83^{a}$ & $3,05^{\mathrm{b}}$ & $3,04^{b}$ & $2,80^{\mathrm{a}}$ & 0,063 & 0,02 \\
\hline EW-opname (/d) & $2,79^{a}$ & $2,78^{a}$ & $2,74^{b}$ & $2,76^{\mathrm{ab}}$ & 0,012 & 0,04 \\
\hline EW-conversie & $3,02^{\mathrm{a}}$ & $3,27^{b}$ & $3,25^{b}$ & $3,00^{\mathrm{a}}$ & 0,067 & 0,02 \\
\hline \multicolumn{7}{|l|}{ Van opleg tot afleveren: } \\
\hline Opleggewicht (kg) & 24,7 & 25,2 & 25,3 & 24,8 & & \\
\hline Levend eindgewicht $(\mathrm{kg})$ & 124,2 & 125,5 & 124,1 & 123,8 & & \\
\hline Groei $(\mathrm{g} / \mathrm{d})$ & $884^{x}$ & $923^{2}$ & $911^{y z}$ & $893^{x y}$ & 10,0 & 0,07 \\
\hline Voeropname (kg/d) & $2,18^{x}$ & $2,29^{y}$ & $2,25^{y}$ & $2,24^{x y}$ & 0,027 & 0,07 \\
\hline Voederconversie & 2,46 & 2,49 & 2,47 & 2,51 & 0,032 & 0,77 \\
\hline EW-opname (/d) & $2,38^{x}$ & $2,51^{y}$ & $2,46^{y}$ & $2,45^{x y}$ & 0,031 & 0,07 \\
\hline EW-conversie & 2,69 & 2,72 & 2,70 & 2,74 & 0,036 & 0,76 \\
\hline
\end{tabular}

${ }^{1}$ SEM = gepoolde standaard error van het gemiddelde (geeft een indicatie van de nauwkeurigheid van de schatting van de gemeten variabele); $a, b, c$ Gemiddelden met een verschillende letter binnen een rij zijn verschillend $(p<0,05) ; x, y, z$ Gemiddelden met een verschillende letter binnen een rij zijn verschillend $(p<0,10)$

Uit tabel 7 blijkt dat tijdens de startvoerfase de vleesvarkens die het controlevoer kregen langzamer zijn gegroeid dan de vleesvarkens in de andere drie proefbehandelingen. De groei van de vleesvarkens in de andere drie behandelingen was vergelijkbaar. Er waren geen significante verschillen in voeropname en voederconversie tussen de vier proefbehandelingen. 
In de tussenvoerfase namen de vleesvarkens die het controlevoer kregen of het voer met verlaagd eiwit + een verzurende werking minder voer op en groeiden langzamer dan de vleesvarkens die het voer met verlaagd eiwit of met een verzurende werking kregen. De voederconversie was ongunstiger bij het voer met verlaagd eiwit + een verzurende werking maar verschilde niet tussen de andere drie behandelingen.

In de eindvoerfase groeiden de vleesvarkens die het controlevoer kregen of het voer met verlaagd eiwit + een verzurende werking sneller en hadden een gunstigere voederconversie dan de vleesvarkens die het voer met verlaagd eiwit of met een verzurende werking kregen. De voeropname van de vleesvarkens was hoger bij het controlevoer en het voer met verlaagd eiwit dan bij het voer met een verzurende werking.

De resultaten van opleg tot afleveren van de vier hokken per proefbehandeling (tabel 7) waren vergelijkbaar met die van alle hokken (tabel 6).

\subsubsection{Slachtkwaliteit}

De slachtkwaliteit van de vleesvarkens is weergegeven in tabel 8.

\section{Tabel 8}

Slachtkwaliteit van vleesvarkens die het controle voer, voer met een verlaagd eiwitgehalte, voer met een verzurende werking of voer met een verlaagd eiwitgehalte en een verzurende werking kregen.

\begin{tabular}{|c|c|c|c|c|c|c|}
\hline & Controle & $\begin{array}{c}\text { Verlaagd } \\
\text { eiwit }\end{array}$ & Verzurend & $\begin{array}{c}\text { Verlaagd eiwit + } \\
\text { verzurend }\end{array}$ & SEM ${ }^{1}$ & $\begin{array}{c}\text { P- } \\
\text { waarde }\end{array}$ \\
\hline Aantal dieren & 141 & 141 & 137 & 141 & & \\
\hline Slachtgewicht (kg) & $93,6^{x}$ & $96,1^{y}$ & $95,1^{x y}$ & $96,0^{y}$ & 0,77 & 0,10 \\
\hline Vleespercentage & 59,3 & 58,9 & 59,1 & 59,0 & 0,14 & 0,34 \\
\hline
\end{tabular}

${ }^{1}$ SEM = gepoolde standaard error van het gemiddelde (geeft een indicatie van de nauwkeurigheid van de schatting van de gemeten variabele); ${ }^{a, b, c}$ Gemiddelden met een verschillende letter binnen een rij zijn verschillend $(p<0,05) ; x, y$ Gemiddelden met een verschillende letter binnen een rij zijn verschillend $(p<0,10)$

Uit tabel 8 blijkt dat het slachtgewicht van de controlevarkens lager was dan van de vleesvarkens die het voer met verlaagd eiwit of het voer met verlaagd eiwit + een verzurende werking kregen. Er was geen duidelijk verschil in vleespercentage en spekdikte tussen de vier proefbehandelingen. De vleesvarkens die het voer met verlaagd eiwit + een verzurende werking kregen hadden dikkere spieren dan de vleesvarkens die het voer met verlaagd eiwit voer of met een verzurende werking kregen. Het controlevoer zat hier tussen in.

De karkas- en orgaanbemerkingen zijn weergegeven in tabel 9. 


\section{Tabel 9}

Karkas- en orgaanbemerkingen van vleesvarkens die het controle voer, voer met een verlaagd eiwitgehalte, voer met een verzurende werking of voer met een verlaagd eiwitgehalte en een verzurende werking kregen.

\begin{tabular}{|c|c|c|c|c|c|}
\hline & Controle & $\begin{array}{c}\text { Verlaagd } \\
\text { eiwit }\end{array}$ & Verzurend & $\begin{array}{c}\text { Verlaagd eiwit + } \\
\text { verzurend }\end{array}$ & P-waarde \\
\hline \multicolumn{6}{|c|}{ Karkasbemerkingen (\%): } \\
\hline Aantal beoordeeld ${ }^{1}$ & 138 & 137 & 137 & 135 & \\
\hline Geen bemerkingen & $60,0^{a}$ & $94,9^{b}$ & $63,6^{a}$ & $54,9^{a}$ & $<0,001$ \\
\hline Pleuritis & $37,8^{a}$ & $3,6^{b}$ & $32,8^{a}$ & $43,6^{a}$ & $<0,001$ \\
\hline Ontstoken huid & 0,7 & 0,0 & 0,7 & 0,0 & 2 \\
\hline Ontstoken poot & 1,5 & 1,5 & 2,9 & 1,5 & 2 \\
\hline \multicolumn{6}{|c|}{ Orgaanbemerkingen (\%): } \\
\hline Aantal beoordeeld & 138 & 137 & 137 & 135 & \\
\hline Geen bemerkingen & $97,1^{\mathrm{ab}}$ & $99,3^{a}$ & $67,2^{c}$ & $94,1^{b}$ & $<0,001$ \\
\hline Afgekeurde lever & 0,0 & 0,0 & 0,7 & 0,0 & 2 \\
\hline Aangetaste longen & $2,9^{\mathrm{ab}}$ & $0,7^{a}$ & $32,1^{c}$ & $5,9^{b}$ & $<0,001$ \\
\hline
\end{tabular}

${ }^{1}$ Niet alle afgevoerde varkens zijn beoordeeld in het slachthuis; ${ }^{2}$ Aantallen te laag om te toetsen; a,b,c Gemiddelden met een verschillende letter binnen een rij zijn verschillend $(p<0,05)$

Uit tabel 9 blijkt dat het percentage dieren met pleuritis lager was bij het verlaagd eiwit voer dan bij de andere drie proefbehandelingen. Bij de andere drie behandelingen was het percentage dieren met pleuritis vergelijkbaar. Het percentage dieren met aangetaste longen was eveneens het laagst bij het verlaagd eiwit voer en het hoogst bij het voer met een verzurende werking.

\subsubsection{Uitval en veterinaire behandelingen}

Het aantal uitgevallen en individueel veterinair behandelde vleesvarkens is weergegeven in tabel 10 . Uit deze tabel blijkt dat er geen verschil is in het aantal uitgevallen vleesvarkens tussen de vier proefbehandelingen. Het aantal individueel veterinair behandelde vleesvarkens was hoger bij de vleesvarkens die het controlevoer kregen dan bij de vleesvarkens die voer met verlaagd eiwit of voer met verlaagd eiwit + een verzurende werking kregen. In de controlegroep zijn in één hok alle dieren behandeld tegen PIA. 
Tabel 10

Uitval en individuele veterinaire behandelingen bij vleesvarkens die het controle voer, voer met een verlaagd eiwitgehalte, voer met een verzurende werking of voer met een verlaagd eiwitgehalte en een verzurende werking kregen.

\begin{tabular}{|c|c|c|c|c|c|}
\hline & Controle & $\begin{array}{c}\text { Verlaagd } \\
\text { eiwit }\end{array}$ & Verzurend & $\begin{array}{c}\text { Verlaagd eiwit + } \\
\text { verzurend }\end{array}$ & waarde \\
\hline Aantal dieren opgelegd & 144 & 144 & 144 & 144 & \\
\hline Aantal uitgevallen & 3 & 3 & 6 & 3 & 0,60 \\
\hline - luchtwegaandoening & 0 & 0 & 0 & 2 & 1 \\
\hline - PIA & 0 & 0 & 1 & 0 & 1 \\
\hline - achterblijven & 0 & 0 & 2 & 0 & 1 \\
\hline Aantal behandeld & $23^{a}$ & $10^{\mathrm{b}}$ & $16^{\mathrm{ab}}$ & $10^{\mathrm{b}}$ & 0,03 \\
\hline \multicolumn{6}{|l|}{ Per reden: } \\
\hline - beenwerkaandoening & 7 & 5 & 4 & 3 & 0,59 \\
\hline - luchtwegaandoening & 5 & 1 & 6 & 6 & 0,27 \\
\hline - Streptococcus suis & 1 & 0 & 0 & 0 & 1 \\
\hline - diversen & $10^{2, a}$ & $4^{\mathrm{ab}}$ & $6^{\mathrm{ab}}$ & $1^{\mathrm{b}}$ & 0,04 \\
\hline
\end{tabular}

1 Aantallen te laag om te toetsen; ${ }^{2}$ vier dieren uit één hok met een ontstoken staart; ${ }^{a, b}$ Gemiddelden met een verschillende letter binnen een rij zijn verschillend $(p<0,05)$

\subsubsection{Mestproductie en -samenstelling}

In tabel 11 worden de gemiddelden en de standaarddeviaties van de meetwaarden in de verschillende perioden van het groeitraject voor het mestvolume en de -samenstelling gegeven voor de verschillende voerbehandelingen. Tevens zijn de P-waarden aangegeven voor de effecten van verlaagd eiwitgehalte van het voer, verzurend voer en van het afdelingsblok (blok $1=$ afdeling 11/12; blok $2=$ afdeling 9/10).

Uit tabel 11 blijkt dat het verzurend voer een $\mathrm{pH}$ verlaging geeft van de verse urine en van de urineplassen. De pH van de mest wordt volgens de statistische berekeningen echter vooral beïnvloed door het eiwitgehalte van het voer en het blokeffect en in mindere mate door het verzurend voer. $\mathrm{Er}$ werden geen significante verschillen gevonden in $\mathrm{N}$-gehalten van de urine ( $\mathrm{N}$-totaal en $\mathrm{NH} 4-\mathrm{N}$ ) tussen het controle en laag-eiwit voer. Er was een tendens dat het gehalte in de feces van $\mathrm{N}$-totaal wel lager was in het laag-eiwit voer $(\mathrm{P}=0,10)$. In de mengmest werden wel significant lagere $\mathrm{N}$-totaal en $\mathrm{NH} 4-\mathrm{N}$ gehalten gevonden voor het laag-eiwit voer. Voor het verzurend voer was dit juist enigszins verhoogd. Er was een tendens dat het potentieel NH4-N gehalte (totaal van ureum-N en NH4-N) hoger was in afdelingsblok 1 . Tevens was er een tendens dat het $\mathrm{K}$-gehalte van urineplassen in afdelingsblok 1 hoger was. Opvallend is het lage $\mathrm{K}$-gehalte in urineplassen ten opzichte van het $\mathrm{K}$-gehalte in de verse urine. Aangezien kalium niet kan vervluchtigen lijkt de enige verklaring te zijn dat de kalium is neergeslagen in de urineplassen of zich dusdanig aan de filters heeft gehecht (bij monstername) dat het niet meer in de oplossing gebracht kon worden tijdens de analyse. Er is een tendens dat het dsgehalte van de mest hoger is in afdelingsblok 1; hetzelfde geldt voor het P-gehalte. Er was een tendens dat het K-gehalte in de mest van het verzurend voer iets hoger was; hetzelfde geldt voor het gehalte aan vluchtige vetzuren. Het TIC- (total inorganic carbon) gehalte was significant hoger in de afdeling met het controlevoer ten opzichte van de andere afdelingen. Voor de andere gehalten werden geen significante verschillen gevonden tussen de voerbehandelingen en tussen de afdelingsblokken. 
Tabel 11

Mestproductie en samenstelling van urine, feces en mengmest bij vleesvarkens die het controle voer, voer met een verlaagd eiwitgehalte, voer met een verzurende werking of voer met een verlaagd eiwitgehalte en een verzurende werking kregen. De weergegeven data zijn ongecorrigeerde gemiddelden.

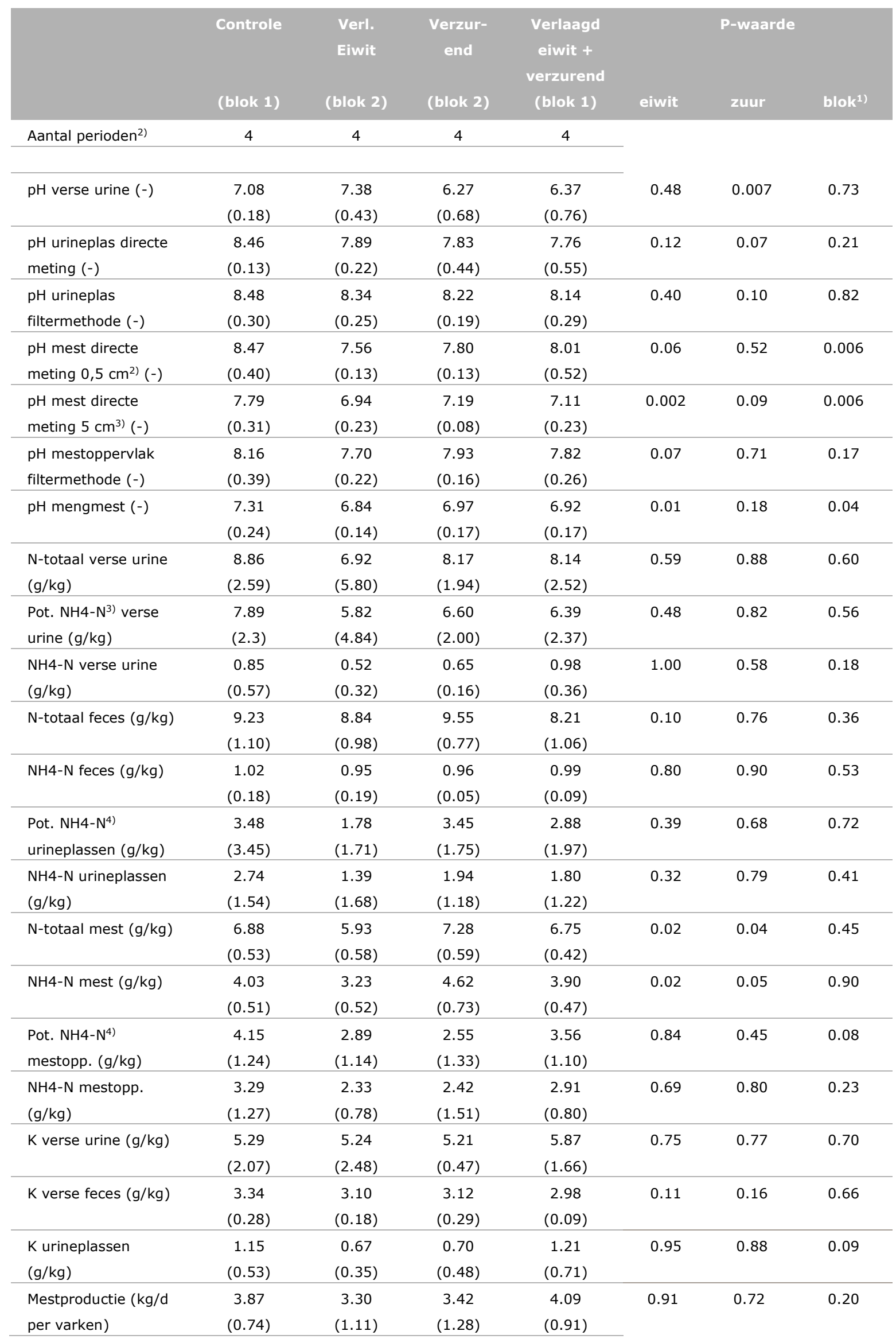




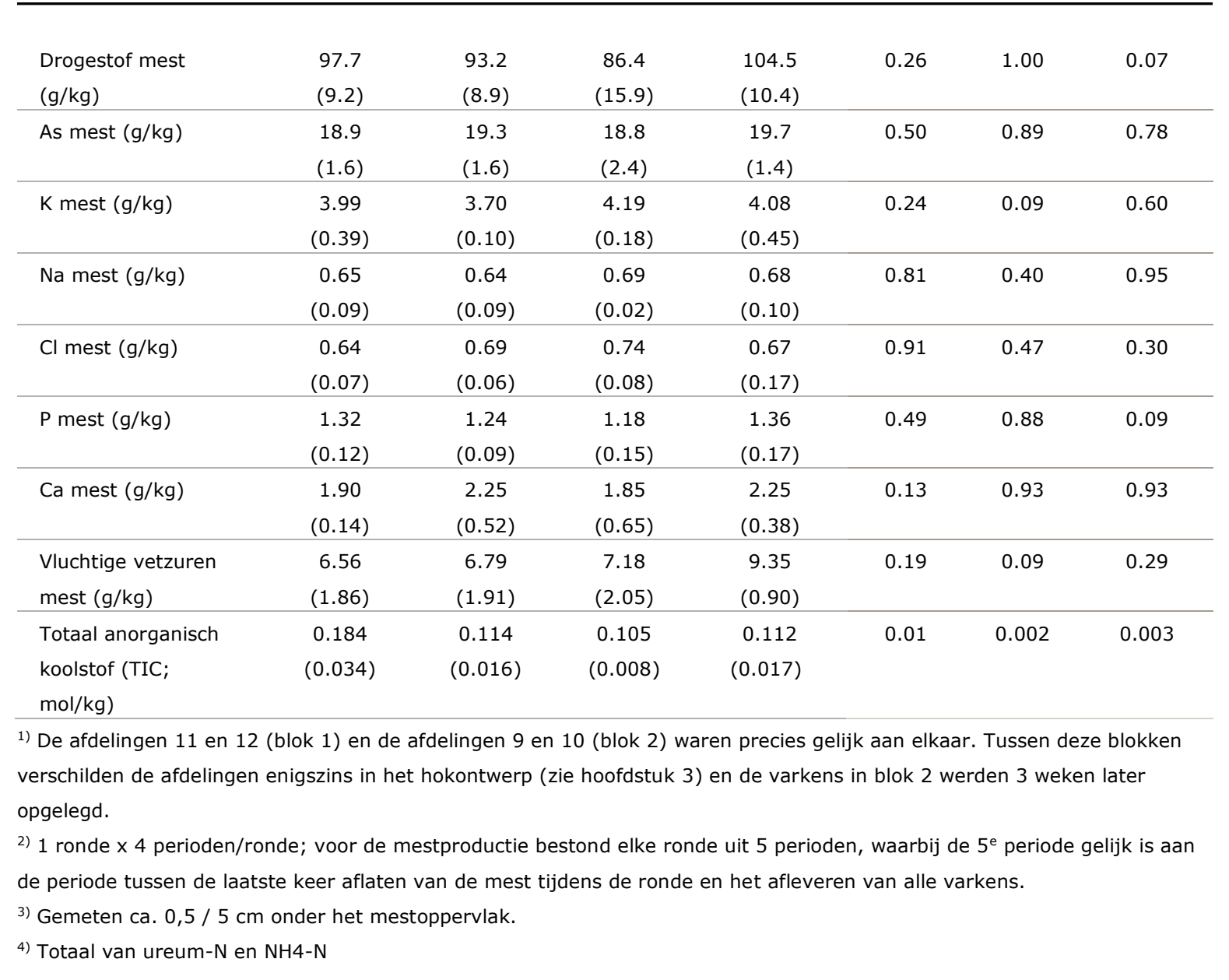

\subsubsection{Bevuilde oppervlakken, temperatuur, luchtsnelheid, ventilatie, verdamping en ammoniakemissie}

In tabel 12 worden de gemiddelden en de standaarddeviaties van de meetwaarden in de verschillende perioden van het groeitraject voor de bevuilde oppervlakken, de temperatuur en luchtsnelheid boven de emitterende oppervlakken, de ventilatie en waterverdamping en de ammoniakemissies gegeven voor de verschillende voerbehandelingen. Tevens zijn de P-waarden aangegeven voor de effecten van verlaagd eiwitgehalte van het voer, verzurend voer en van het afdelingsblok (blok $1=$ afdeling 11/12; blok 2 = afdeling 9/10).

Uit tabel 12 blijkt dat de bevuiling van de vloer niet werd beïnvloed door de voerbehandeling of door afdelingsblok. Het bevuild oppervlak van de achterste mestkelder was significant groter voor afdelingsblok 2. Dit is logisch aangezien deze mestkelder breder is dan in afdelingsblok 1 (zie hfdstk 3). Hetzelfde geldt voor het oppervlak van de voorste mestkelder. Het oppervlak van de schuine wanden in de achterste mestkelder is ook groter in blok 2 dan in blok 1, vandaar het significante effect op het bevuild oppervlak van deze wanden. Er was een tendens dat de oppervlaktetemperatuur van de urineplassen in blok 2 hoger was dan in blok 1. De oppervlaktetemperatuur van de mest in de mestkelder was ca. $2^{\circ} \mathrm{C}$ lager in de afdeling met het controlevoer ten opzichte van de andere afdelingen. De luchtsnelheden boven de urineplassen en boven de mest in de kelder verschilden niet voor de verschillende behandelingen. 
Tabel 12

Bevuilde oppervlakken, temperatuur, luchtsnelheid, ventilatie, waterverdamping en ammoniakemissie bij vleesvarkens die het controle voer, voer met een verlaagd eiwitgehalte, voer met een verzurende werking of voer met een verlaagd eiwitgehalte en een verzurende werking kregen. De weergegeven data zijn ongecorrigeerde gemiddelden.

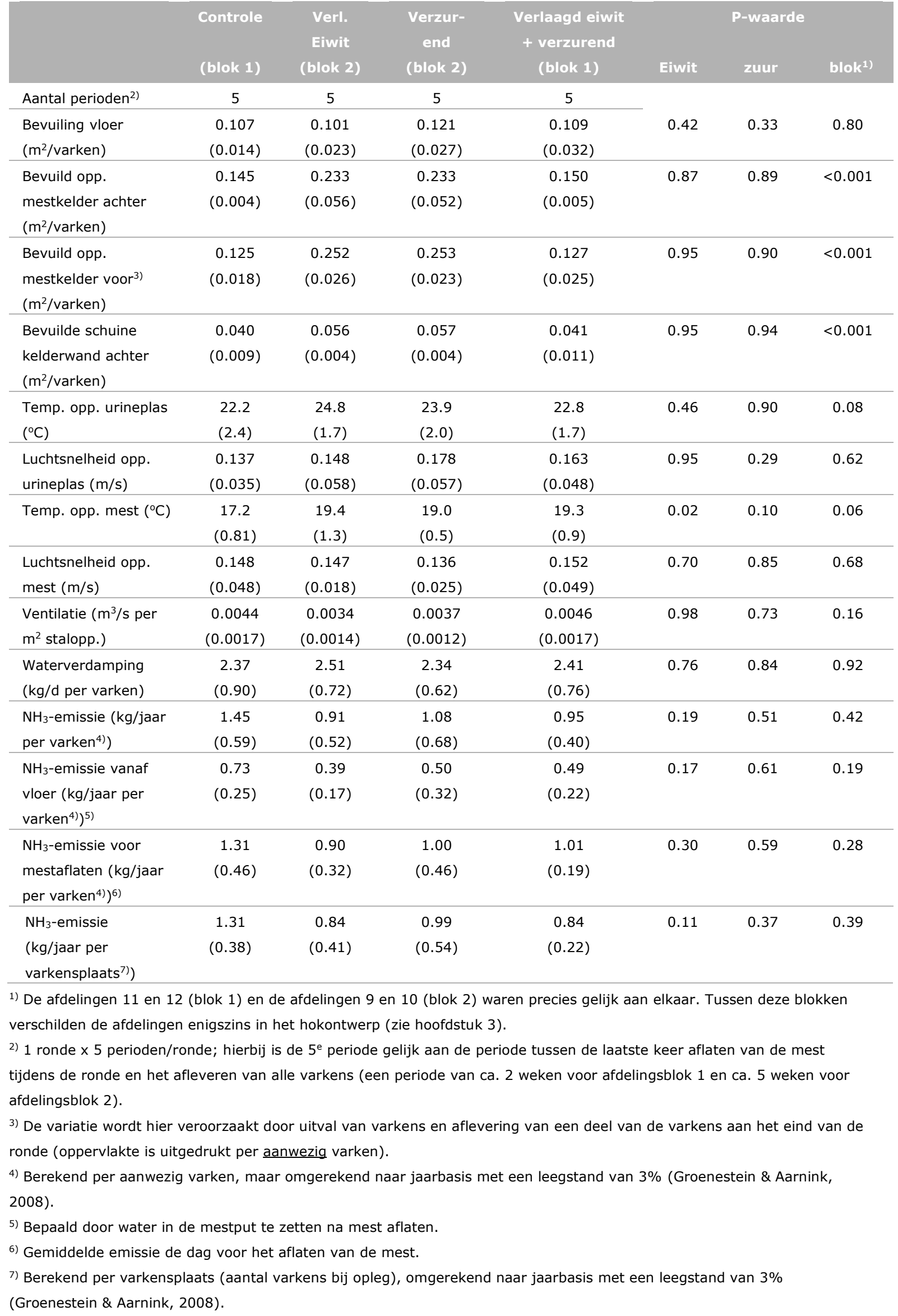




\subsection{Gespeende biggen}

\subsubsection{Technische resultaten hele opfokperiode (alle hokken)}

De technische resultaten van de biggen van spenen tot 35 dagen na spenen zijn weergegeven in tabel 13.

\section{Tabel 13}

Technische resultaten van spenen tot 35 dagen na spenen van biggen die het controle voer, voer met een verlaagd eiwitgehalte, voer met een verzurende werking of voer met een verlaagd eiwitgehalte en een verzurende werking kregen.

\begin{tabular}{|c|c|c|c|c|c|c|}
\hline & Controle & $\begin{array}{l}\text { Verlaagd } \\
\text { eiwit }\end{array}$ & Verzurend & $\begin{array}{c}\text { Verlaagd eiwit + } \\
\text { verzurend }\end{array}$ & SEM $^{1}$ & P-waarde \\
\hline Aantal dieren & 192 & 192 & 192 & 192 & & \\
\hline Aantal hokken & 16 & 16 & 16 & 16 & & \\
\hline Speengewicht $(\mathrm{kg})$ & 8,3 & 8,3 & 8,3 & 8,3 & & \\
\hline Eindgewicht $(\mathrm{kg})$ & 22,4 & 22,2 & 21,8 & 21,8 & & \\
\hline Groei $(g / d)$ & 403 & 397 & 386 & 385 & 8,3 & 0,38 \\
\hline Voeropname $(\mathrm{kg} / \mathrm{d})$ & 0,56 & 0,56 & 0,54 & 0,54 & 0,013 & 0,50 \\
\hline Voederconversie & 1,39 & 1,41 & 1,39 & 1,41 & 0,013 & 0,47 \\
\hline EW-opname $(/ d)$ & 0,62 & 0,62 & 0,59 & 0,60 & 0,014 & 0,50 \\
\hline EW-conversie & 1,53 & 1,56 & 1,54 & 1,56 & 0,014 & 0,47 \\
\hline
\end{tabular}

${ }^{1}$ SEM $=$ gepoolde standaard error van het gemiddelde (geeft een indicatie van de nauwkeurigheid van de schatting van de gemeten variabele)

Uit tabel 13 blijkt dat er van spenen tot 35 dagen na spenen geen significante verschillen zijn in groei, voeropname en voederconversie tussen de vier proefbehandelingen.

\subsubsection{Technische resultaten per gewichtstraject}

In acht hokken per proefbehandeling (vier hokken per ronde) zijn de dieren gewogen bij de overschakeling van speenvoer naar opfokvoer. De technische resultaten van deze biggen van spenen tot 16 dagen na spenen, van 16 tot 35 dagen na spenen en van spenen tot 35 dagen na spenen zijn weergegeven in tabel 14. 
Tabel 14

Technische resultaten per gewichtstraject en van spenen tot 35 dagen na spenen ( 8 hokken per proefbehandeling) van biggen die het controle voer, voer met een verlaagd eiwitgehalte, voer met een verzurende werking of voer met een verlaagd eiwitgehalte en een verzurende werking kregen.

\begin{tabular}{|c|c|c|c|c|c|c|}
\hline & Controle & $\begin{array}{c}\text { Verlaagd } \\
\text { eiwit }\end{array}$ & Verzurend & $\begin{array}{c}\text { Verlaagd eiwit + } \\
\text { verzurend }\end{array}$ & $S E M^{1}$ & waarde \\
\hline Aantal dieren & 96 & 96 & 96 & 96 & & \\
\hline Aantal hokken & 8 & 8 & 8 & 8 & & \\
\hline \multicolumn{7}{|c|}{ Van opleg tot 16 dagen na opleg: } \\
\hline Opleggewicht (kg) & 8,3 & 8,3 & 8,3 & 8,3 & & \\
\hline Tussengewicht $(\mathrm{kg})$ & 11,9 & 11,6 & 11,5 & 11,1 & & \\
\hline Groei (g/d) & $226^{a}$ & $211^{a}$ & $204^{a}$ & $179^{\mathrm{b}}$ & 8,7 & 0,006 \\
\hline Voeropname $(\mathrm{kg} / \mathrm{d})$ & $0,30^{\mathrm{a}}$ & $0,29^{a}$ & $0,28^{\mathrm{ab}}$ & $0,26^{b}$ & 0,010 & 0,05 \\
\hline Voederconversie & $1,33^{a}$ & $1,37^{\mathrm{a}}$ & $1,36^{\mathrm{a}}$ & $1,48^{\mathrm{b}}$ & 0,030 & 0,008 \\
\hline EW-opname $(/ d)$ & $0,34^{a}$ & $0,32^{\mathrm{a}}$ & $0,31^{\mathrm{ab}}$ & $0,29^{b}$ & 0,011 & 0,05 \\
\hline EW-conversie & $1,49^{a}$ & $1,53^{a}$ & $1,52^{\mathrm{a}}$ & $1,66^{\mathrm{b}}$ & 0,033 & 0,008 \\
\hline \multicolumn{7}{|c|}{ Van 16 tot 35 dagen na opleg: } \\
\hline Tussengewicht $(\mathrm{kg})$ & 11,9 & 11,6 & 11,5 & 11,1 & & \\
\hline Eindgewicht $(\mathrm{kg})$ & 22,7 & 22,1 & 21,6 & 21,3 & & \\
\hline Groei $(g / d)$ & 566 & 551 & 529 & 536 & 20,2 & 0,57 \\
\hline Voeropname $(\mathrm{kg} / \mathrm{d})$ & 0,80 & 0,79 & 0,74 & 0,76 & 0,030 & 0,46 \\
\hline Voederconversie & 1,42 & 1,43 & 1,40 & 1,42 & 0,024 & 0,84 \\
\hline EW-opname $(/ d)$ & 0,88 & 0,87 & 0,82 & 0,84 & 0,033 & 0,46 \\
\hline EW-conversie & 1,56 & 1,58 & 1,54 & 1,56 & 0,027 & 0,84 \\
\hline \multicolumn{7}{|c|}{ Van opleg tot 35 dagen na opleg: } \\
\hline Opleggewicht (kg) & 8,3 & 8,3 & 8,3 & 8,3 & & \\
\hline Eindgewicht $(\mathrm{kg})$ & 22,7 & 22,1 & 21,6 & 21,3 & & \\
\hline Groei (g/d) & 411 & 395 & 380 & 372 & 12,5 & 0,17 \\
\hline Voeropname $(\mathrm{kg} / \mathrm{d})$ & 0,57 & 0,56 & 0,53 & 0,53 & 0,019 & 0,30 \\
\hline Voederconversie & 1,40 & 1,42 & 1,39 & 1,43 & 0,018 & 0,39 \\
\hline EW-opname $(/ d)$ & 0,63 & 0,62 & 0,58 & 0,59 & 0,021 & 0,30 \\
\hline EW-conversie & 1,54 & 1,57 & 1,53 & 1,58 & 0,020 & 0,39 \\
\hline
\end{tabular}

${ }^{1}$ SEM = gepoolde standaard error van het gemiddelde (geeft een indicatie van de nauwkeurigheid van de schatting van de gemeten variabele); ${ }^{a, b}$ Gemiddelden met een verschillende letter binnen een hoofdeffect binnen een rij zijn verschillend ( $p$ $<0,05)$

Uit tabel 14 blijkt dat de biggen die het voer met verlaagd eiwit + een verzurende werking kregen minder voer hebben opgenomen, langzamer gegroeid zijn en een ongunstigere voederconversie hadden van spenen tot 16 dagen na spenen dan de biggen in de andere drie proefbehandelingen. Tussen de biggen in de andere drie proefbehandelingen zijn er geen verschillen in technische resultaten van spenen tot 16 dagen na spenen.

Van dag 16 tot dag 35 na spenen en van opleg tot 35 dagen na spenen zijn er geen verschillen in technische resultaten tussen de vier proefbehandelingen.

\subsubsection{Uitval en veterinaire behandelingen}

Het aantal uitgevallen biggen en het aantal individueel veterinair behandelde biggen is weergegeven in tabel 15 . Tevens is de reden van uitval en van behandelen weergegeven. 
Tabel 15

Uitval en individuele veterinaire behandelingen bij gespeende biggen die het controle voer, voer met een verlaagd eiwitgehalte, voer met een verzurende werking of voer met een verlaagd eiwitgehalte en een verzurende werking kregen.

\begin{tabular}{|c|c|c|c|c|c|}
\hline & Controle & $\begin{array}{c}\text { Verlaagd } \\
\text { eiwit }\end{array}$ & Verzurend & $\begin{array}{c}\text { Verlaagd eiwit + } \\
\text { verzurend }\end{array}$ & $\begin{array}{c}\text { P- } \\
\text { waarde }\end{array}$ \\
\hline Aantal dieren opgelegd & 192 & 192 & 192 & 192 & \\
\hline Aantal uitgevallen & $2^{x}$ & $6^{x y}$ & $11^{y}$ & $6^{x y}$ & 0,08 \\
\hline - luchtwegaandoening & 0 & 1 & 0 & 0 & 1 \\
\hline - Streptococcen suis & 1 & 3 & 5 & 4 & 1 \\
\hline - achterblijven in groei & 1 & 1 & 2 & 1 & 1 \\
\hline - diversen & 0 & 0 & 4 & 1 & 1 \\
\hline \multicolumn{6}{|l|}{ Per reden: } \\
\hline - beenwerkaandoening & $5^{a}$ & $8^{a}$ & $25^{b}$ & $6^{a}$ & $<0,001$ \\
\hline - Streptococcus suis & 6 & 3 & 10 & 7 & 0,26 \\
\hline - luchtwegaandoening & 4 & 2 & 1 & 3 & 1 \\
\hline - diversen & 0 & 1 & 3 & 1 & 1 \\
\hline
\end{tabular}

Uit tabel 15 blijkt dat het aantal uitgevallen biggen in de controlegroep lager was dan bij de biggen die het voer met verzurende werking kregen. De uitval in de twee andere proefbehandelingen zat hier tussen in. Het individueel aantal veterinair behandelde biggen was hoger bij het voer met verzurende werking dan bij de andere drie proefbehandelingen. Met name het aantal biggen behandeld vanwege beenwerkaandoeningen was hoger bij het voer met een verzurende werking. In ronde 2 zijn alle biggen in alle proefbehandelingen vanwege een Streptococcus suis infectie behandeld via het drinkwater.

\subsubsection{Mestproductie en -samenstelling}

In tabel 16 worden de gemiddelden en de standaarddeviaties van de meetwaarden in de beide ronden/perioden voor het mestvolume en de -samenstelling gegeven voor de verschillende voerbehandelingen. Tevens zijn de P-waarden aangegeven voor de effecten van verlaagd eiwitgehalte van het voer, verzurend voer en van een eventueel afdelingseffect.

Uit tabel 16 blijkt dat er vrijwel geen enkel effect significant werd berekend voor de verschillende gemeten parameters. Dit werd waarschijnlijk vooral veroorzaakt door de grote spreiding in de metingen. De grote spreiding in de metingen werd waarschijnlijk voor een belangrijk deel veroorzaakt doordat er relatief weinig mest werd geproduceerd die vooral wegliep in de rioleringspijpen (die aan het eind afgesloten waren). Daardoor stond er na 2 weken vrijwel geen mest in de mestkelder en na 4 weken nog maar een paar $\mathrm{cm}$. Representatieve monstername was daardoor moeilijk. Door de volledige roostervloer konden ook geen metingen worden gedaan aan urineplassen, alleen directe meting aan urine die bleef liggen op niet doorgetrapte mest. Opvallend is het significant lagere $\mathrm{N}$ totaal gehalte van de verse urine van de voerbehandeling met de combi van verlaagd eiwit en verzurende werking. Hetzelfde geldt voor het (potentieel) gehalte aan NH4-N in de verse urine. De oorzaak zou voor een deel veroorzaakt kunnen zijn doordat de voeropname en de groei van deze behandeling gedurende de eerste 16 dagen significant lager was dan bij de andere behandelingen (zie par. 4.2.2). De overige gehalten en $\mathrm{pH}^{\prime} \mathrm{s}$ van de urine, feces en mest waren niet (significant) verschillend tussen de behandelingen. 
Tabel 16

Mestproductie en samenstelling van urine, feces en mengmest bij biggen die het controle voer, voer met een verlaagd eiwitgehalte, voer met een verzurende werking of voer met een verlaagd eiwitgehalte en een verzurende werking kregen. De weergegeven data zijn ongecorrigeerde gemiddelden.

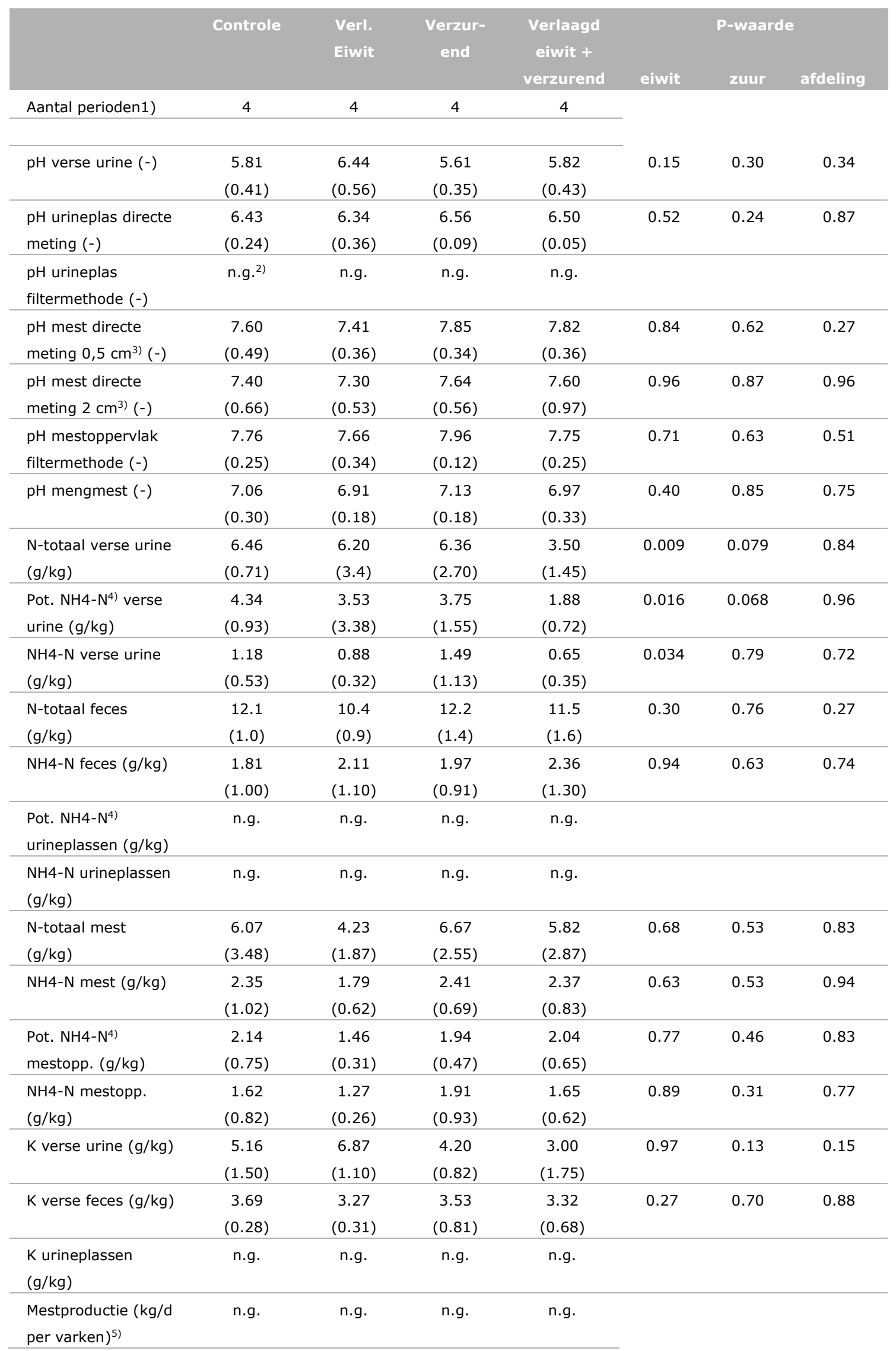




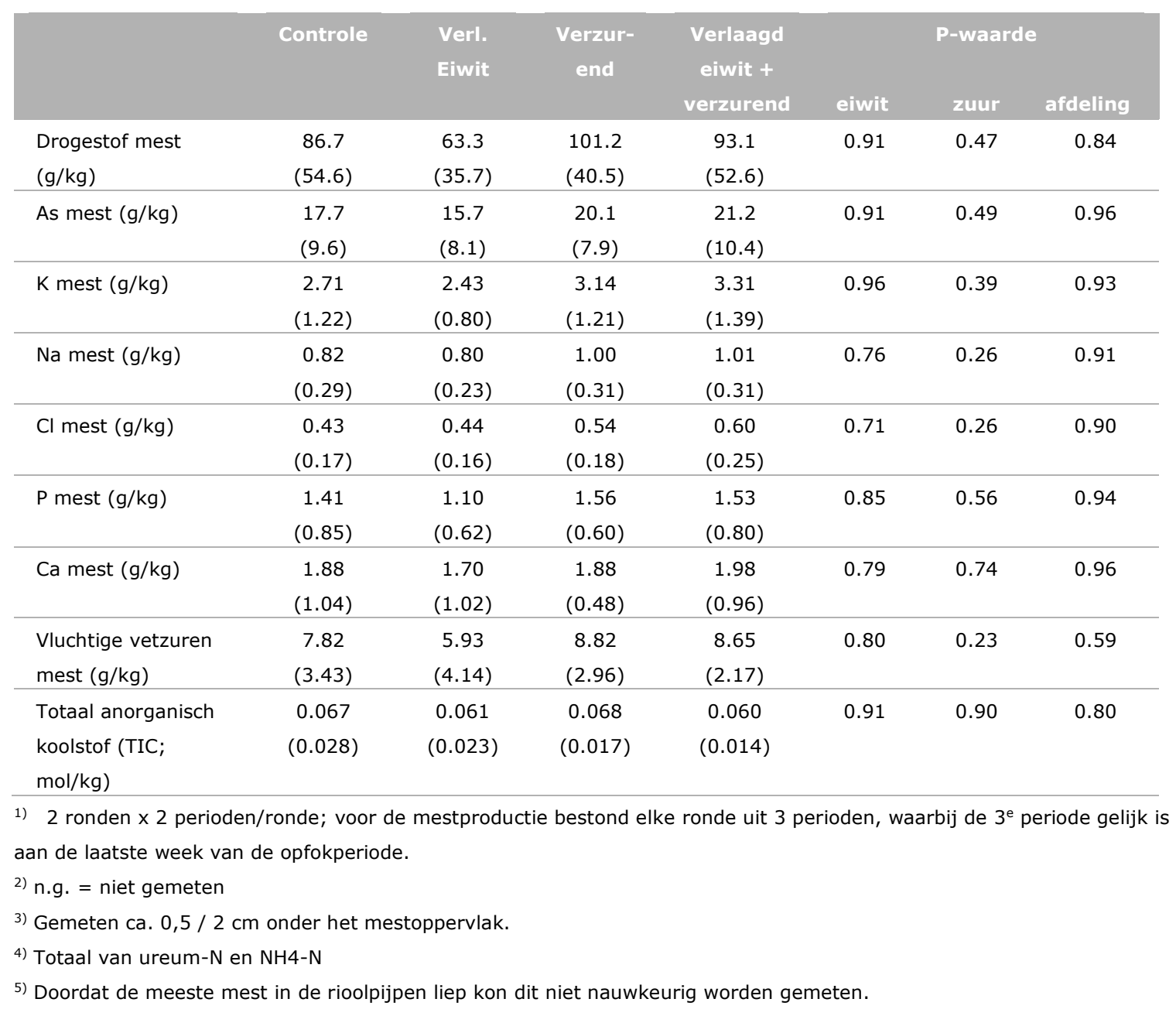

\subsubsection{Bevuilde oppervlakken, temperatuur, luchtsnelheid, ventilatie, verdamping en ammoniakemissie}

In tabel 17 worden de gemiddelden en de standaarddeviaties van de meetwaarden in de verschillende perioden van het groeitraject voor de bevuilde oppervlakken, de temperatuur en luchtsnelheid boven de emitterende oppervlakken, de ventilatie en waterverdamping en de ammoniakemissies gegeven voor de verschillende voerbehandelingen. Tevens zijn de P-waarden aangegeven voor de effecten van verlaagd eiwitgehalte van het voer, verzurend voer en van de afdeling.

Uit tabel 17 blijkt dat alle gemeten variabelen zeer vergelijkbaar waren voor de verschillende voerbehandelingen en er werden ook geen significante verschillen tussen de afdelingen gevonden. Wel moet opgemerkt worden dat de variatie tussen de verschillende perioden/ronden steeds vrij groot is, waardoor verschillen niet snel significant worden. Het effect van het eiwitgehalte van het voer op de totale ammoniakemissie is bijna significant $(P=0,11)$. 
Tabel 17

Bevuilde oppervlakken, temperatuur, luchtsnelheid, ventilatie, waterverdamping en ammoniakemissie bij biggen die het controle voer, voer met een verlaagd eiwitgehalte, voer met een verzurende werking of voer met een verlaagd eiwitgehalte en een verzurende werking kregen. De weergegeven data zijn ongecorrigeerde gemiddelden.

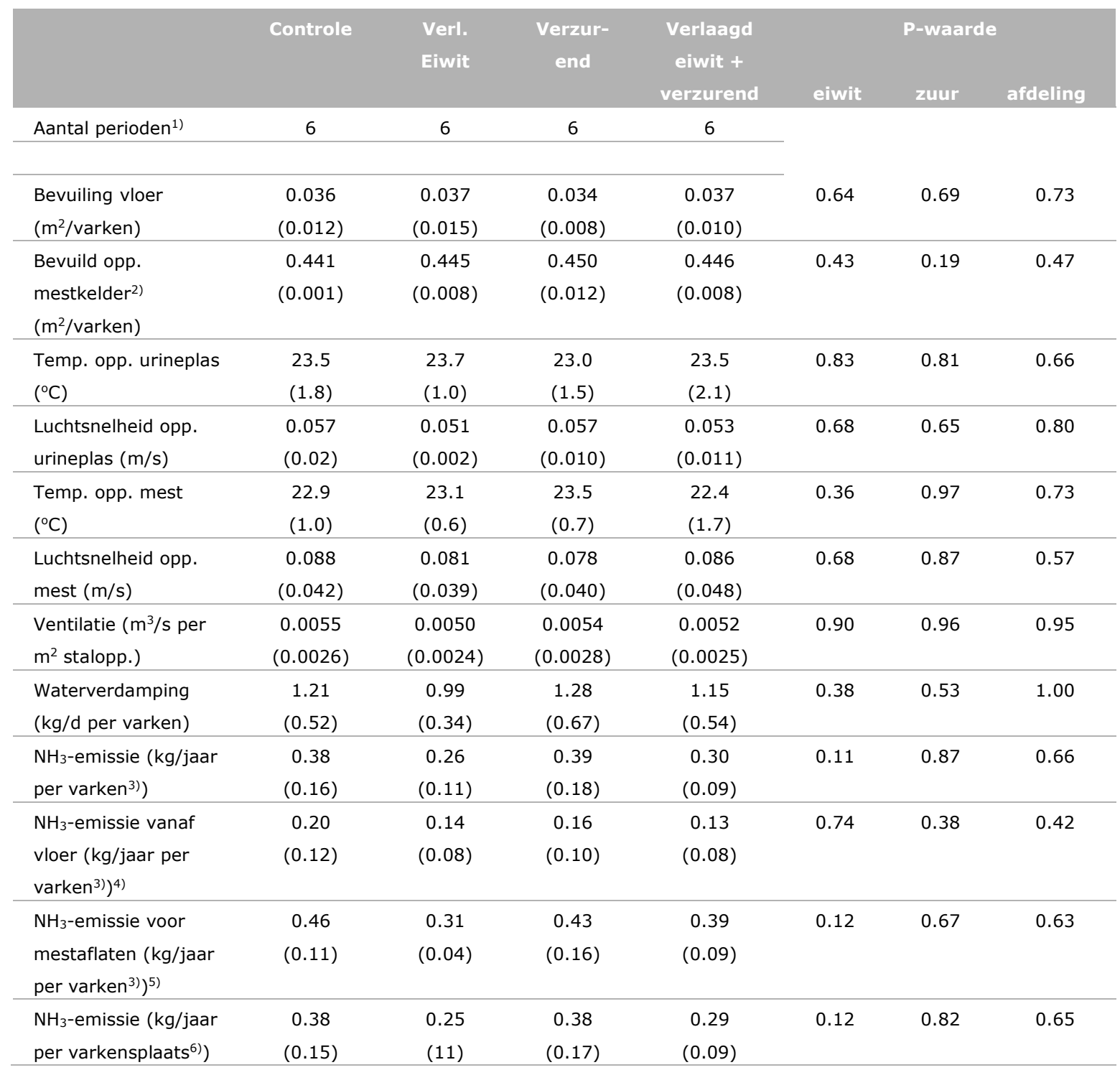

1) 2 ronden $x 3$ perioden/ronde; de $3^{e}$ periode is daarbij gelijk aan de laatste week van de opfokperiode.

2) De variatie wordt hier veroorzaakt door uitval van biggen (oppervlakte is uitgedrukt per aanwezig varken).

3) Berekend per aanwezig varken, maar omgerekend naar jaarbasis met een leegstand van $9 \%$ (Groenestein \& Aarnink, 2008).

4) Bepaald door water in de mestput te zetten na mest aflaten.

5) Gemiddelde emissie de dag voor het aflaten van de mest.

6) Berekend per varkensplaats (aantal varkens bij opleg), omgerekend naar jaarbasis met een leegstand van $9 \%$ (Groenestein \& Aarnink, 2008).

\subsection{Drachtige zeugen}

\subsubsection{Voeropname en diergewicht}

De voeropname in de drachtstal van de zeugen die het controlevoer of het proefvoer kregen en het gewicht bij inzet in de drachtstal (start proefperiode) en bij inzet in de kraamstal (einde proefperiode) zijn weergegeven in tabel 18 . 
Tabel 18

Voeropname, gewicht en spekdikte in de drachtstal van de drachtige zeugen die het controlevoer of het proefvoer kregen.

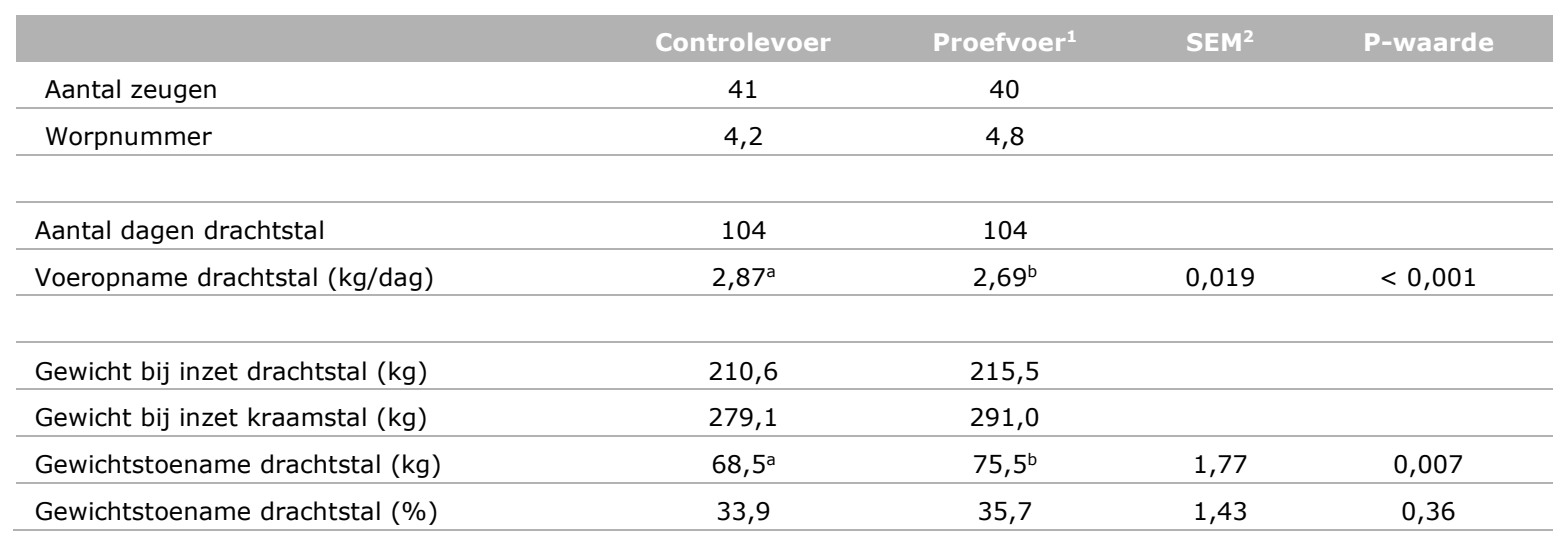

${ }^{1}$ Het proefvoer bevatte $15 \mathrm{~g} / \mathrm{kg}$ minder eiwit en $29 \mathrm{~g} / \mathrm{kg}$ meer VNSP dan het controlevoer en $\mathrm{CaCO}_{3}$ was vervangen door Caformiaat; ${ }^{2}$ SEM = gepoolde standaard error van het gemiddelde (geeft een indicatie van de nauwkeurigheid van de schatting van de gemeten variabele); ${ }^{a, b}$ Gemiddelden met een verschillende letter binnen een rij zijn verschillend $(p<0,05)$

Uit tabel 18 blijkt dat het gewicht van de zeugen bij inzet in de drachtstal (start proefperiode) niet verschilde tussen de twee groepen zeugen. Bij inzet in de kraamstal (einde proefperiode) waren de zeugen op het proefvoer echter zwaarder dan de zeugen op het controlevoer. De zeugen op het proefvoer waren $7 \mathrm{~kg}$ meer in gewicht toegenomen dan de zeugen op het controlevoer terwijl ze minder voer op hebben genomen tijdens de dracht.

In de controlegroep zijn meer zeugen veterinair behandeld dan in de proefgroep ( 9 versus 2 zeugen; $p$ $=0,026)$. In de controlegroep zijn 8 van de 9 zeugen behandeld vanwege kreupelheid, in de proefgroep was dit één van de twee zeugen.

\subsubsection{Mestproductie en -samenstelling}

In tabel 19 worden de gemiddelden en de standaarddeviaties van de meetwaarden in de verschillende perioden voor het mestvolume en de -samenstelling gegeven voor de beide voerbehandelingen. Tevens zijn de P-waarden aangegeven voor het effect van het proefvoer (verlaagd eiwit en vervanging Ca-carbonaat door Ca-formiaat) gegeven.

Uit tabel 19 blijkt dat de gemeten variabelen tussen controle- en proefvoer heel weinig van elkaar verschilden. De pH's van de urine waren zeer vergelijkbaar. De pH's van de mest lijken iets lager te zijn bij het proefvoer ( $\mathrm{P}=0,087$ voor de $\mathrm{pH}$ van de mengmest). $\mathrm{Er}$ is ook weinig verschil te constateren tussen de $\mathrm{N}$-gehalten van urine, feces en mest. We meten zelfs een hogere NH4-N gehalte in de mengmest van de proefafdeling $(P=0,034)$. Dit laatste is niet volgens verwachting aangezien het eiwitgehalte van het proefvoer $15 \mathrm{~g} / \mathrm{kg}$ lager was ingesteld. Uiteindelijk bleek dit volgens de analyses $11 \mathrm{~g} / \mathrm{kg}$ lager te zijn (zie bijlage 5). Aangezien de zeugen met het proefvoer ook nog meer gegroeid zijn tijdens de drachtperiode (zie vorige paragraaf), lijkt het er op dat het controle- en het proefvoer niet alleen verschilde in het eiwitgehalte, maar dat er door de andere grondstoffen die gebruikt zijn ook andere effecten zijn opgetreden. Ondanks dat de berekende verteringscoëfficiënten van de beide voeders vrijwel gelijk waren (zie bijlage 5), is de meest logische verklaring dat er toch verschillen waren in de verteerbaarheid van het ruweiwit tussen beide voeders. Er was een tendens tot een hoger $\mathrm{K}$-gehalte van de mest in de proefafdeling $(P=0,076)$ en het Ca-gehalte was significant hoger $(P=0,047)$. De gehalten van de overige componenten in de mest verschilden niet significant. 
Tabel 19

Mestproductie en samenstelling van urine, feces en mengmest bij zeugen die het controlevoer en het proefvoer (verlaagd eiwit en vervanging Ca-carbonaat door Ca-formiaat) kregen.

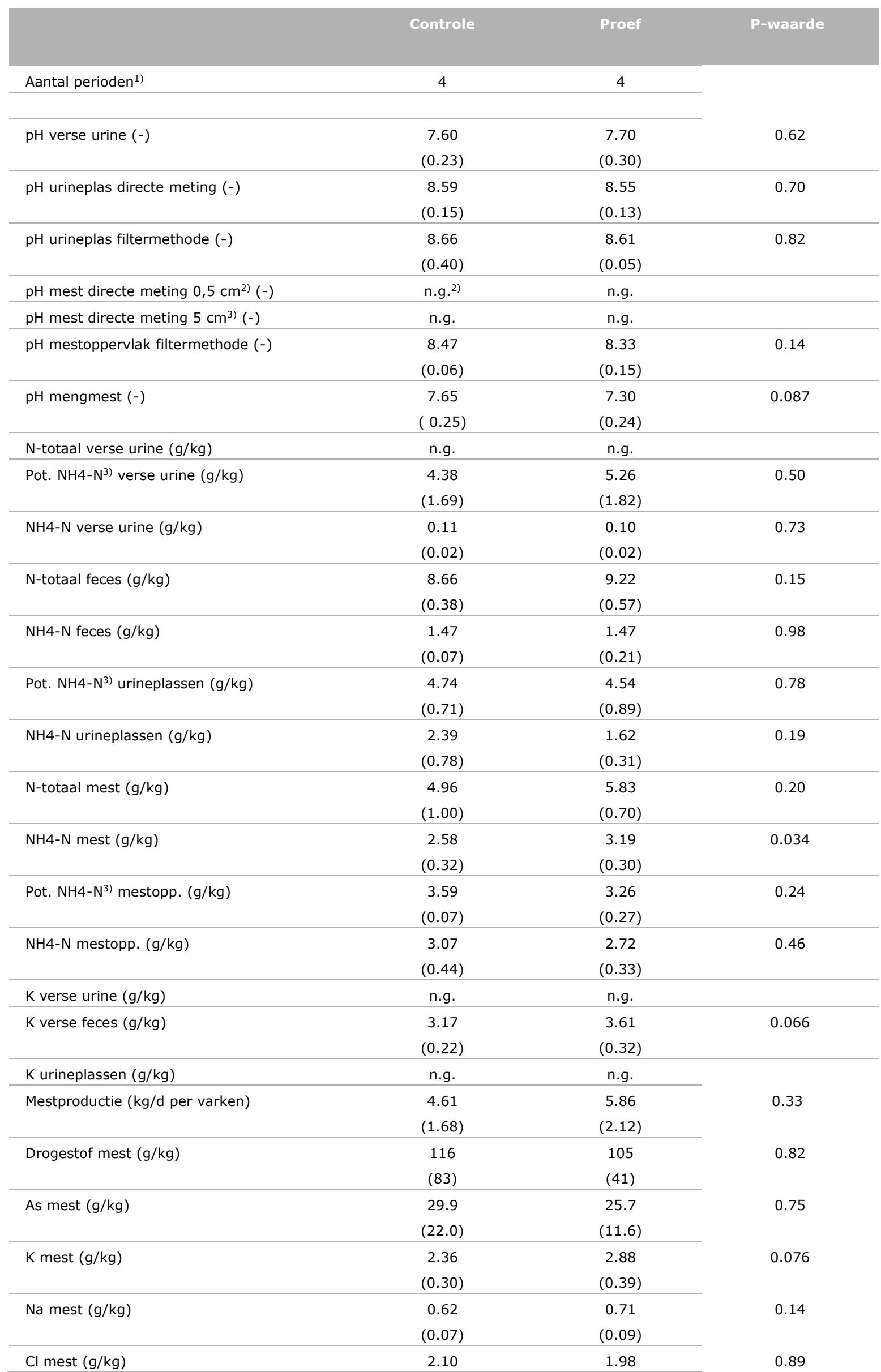




\begin{tabular}{|c|c|c|c|}
\hline & Controle & Proef & P-waarde \\
\hline & $(1.34)$ & $(0.82)$ & \\
\hline \multirow[t]{2}{*}{$P$ mest $(\mathrm{g} / \mathrm{kg})$} & 3.07 & 2.40 & 0.43 \\
\hline & $(1.57)$ & $(0.20)$ & \\
\hline \multirow[t]{2}{*}{ Ca mest $(\mathrm{g} / \mathrm{kg})$} & 0.20 & 0.25 & 0.047 \\
\hline & $(0.02)$ & $(0.04)$ & \\
\hline \multirow[t]{2}{*}{ Vluchtige vetzuren mest $(\mathrm{g} / \mathrm{kg})$} & 2.91 & 4.80 & 0.33 \\
\hline & $(2.84)$ & $(2.12)$ & \\
\hline Totaal anorganisch koolstof $(\mathrm{TIC} ; \mathrm{mol} / \mathrm{kg})^{4)}$ & 0.18 & 0.12 & \\
\hline \multicolumn{4}{|c|}{$\begin{array}{l}\text { 1) } 1 \text { ronde } \times 4 \text { perioden/ronde; voor de mestproductie bestond elke ronde uit } 5 \text { perioden, waarbij de } 5^{\mathrm{e}} \text { periode gelijk is aan } \\
\text { de periode tussen de laatste keer aflaten van de mest tijdens de ronde en het einde van de proef (ca. } 2 \text { weken voor zowel } \\
\text { de controle- als de proefafdeling). }\end{array}$} \\
\hline \multicolumn{4}{|c|}{ 2) n.g. = niet gemeten } \\
\hline \multicolumn{4}{|l|}{ 3) Totaal van ureum- $\mathrm{N}$ en $\mathrm{NH} 4-\mathrm{N}$} \\
\hline 4) Slechts 1 meting per behandeling & & & \\
\hline
\end{tabular}

\subsubsection{Bevuilde oppervlakken, temperatuur, luchtsnelheid, ventilatie, verdamping en ammoniakemissie}

In tabel 20 worden de gemiddelden en de standaarddeviaties van de meetwaarden in de verschillende perioden van het groeitraject voor de bevuilde oppervlakken, de temperatuur en luchtsnelheid boven de emitterende oppervlakken, de ventilatie en waterverdamping en de ammoniakemissies gegeven voor de beide voerbehandelingen. Tevens zijn de P-waarden aangegeven voor de effecten van verlaagd eiwitgehalte van het voer, verzurend voer en van het afdelingsblok (blok 1 = afdeling 11/12; blok 2 = afdeling 9/10).

Uit tabel 20 blijkt dat de bevuiling van de vloer, het bevuilde mestoppervlak van de mestkelder en van de schuine wanden zeer vergelijkbaar waren voor de controle- en de proefafdeling. Dit geldt ook voor de luchtsnelheden over de emitterende oppervlakken en voor de ventilatie. De temperatuur van de oppervlakte van de urineplassen verschilde niet in beide afdelingen, echter wel de temperatuur van de oppervlakte van de mest in de mestkelder. Deze was voor de proefafdeling ca. $2^{\circ} \mathrm{C}$ lager $(P=0,008)$. De waterverdamping en de totale ammoniakemissie en de ammoniakemissie van de vloer waren ook zeer vergelijkbaar tussen beide afdelingen. 
Tabel 20

Bevuilde oppervlakken, temperatuur, luchtsnelheid, ventilatie, waterverdamping en ammoniakemissie bij zeugen die het controlevoer en het proefvoer (verlaagd eiwit en vervanging Ca-carbonaat door Caformiaat) kregen.

\begin{tabular}{|c|c|c|c|}
\hline & Controle & Proef & P-waarde \\
\hline Aantal perioden ${ }^{1)}$ & 5 & 5 & \\
\hline \multirow[t]{2}{*}{ Bevuiling vloer (m²/varken) } & 0.40 & 0.40 & 0.91 \\
\hline & $(0.14)$ & $(0.10)$ & \\
\hline \multirow[t]{2}{*}{ Bevuild opp. mestkelder (m²/varken) } & 0.48 & 0.45 & 0.56 \\
\hline & $(0.09)$ & $(0.06)$ & \\
\hline \multirow[t]{2}{*}{ Bevuilde schuine kelderwand ( $\mathrm{m}^{2} /$ varken) } & 0.22 & 0.24 & 0.26 \\
\hline & $(0.03)$ & $(0.02)$ & \\
\hline \multirow[t]{2}{*}{ Temp. opp. urineplas $\left({ }^{\circ} \mathrm{C}\right)$} & 19.1 & 18.8 & 0.73 \\
\hline & $(1.1)$ & $(1.3)$ & \\
\hline \multirow[t]{2}{*}{ Luchtsnelheid opp. urineplas (m/s) } & 0.16 & 0.14 & 0.20 \\
\hline & $(0.03)$ & $(0.03)$ & \\
\hline \multirow[t]{2}{*}{ Temp. opp. mest $\left({ }^{\circ} \mathrm{C}\right)$} & 18.6 & 16.5 & 0.008 \\
\hline & $(0.7)$ & $(0.7)$ & \\
\hline \multirow[t]{2}{*}{ Luchtsnelheid opp. mest (m/s) } & 0.036 & 0.046 & 0.36 \\
\hline & $(0.018)$ & $(0.011)$ & \\
\hline \multirow[t]{2}{*}{ Ventilatie ( $\mathrm{m}^{3} / \mathrm{s}$ per $\mathrm{m}^{2}$ stalopp.) } & 0.0043 & 0.0044 & 0.94 \\
\hline & $(0.0017)$ & $(0.0016)$ & \\
\hline \multirow[t]{2}{*}{ Waterverdamping (kg/d per varken) } & 3.44 & 3.59 & 0.60 \\
\hline & $(0.49)$ & $(0.33)$ & \\
\hline \multirow[t]{2}{*}{$\mathrm{NH}_{3}$-emissie $\left(\mathrm{kg} / \mathrm{jaar}\right.$ per varken $\left.{ }^{2)}\right)$} & 2.98 & 2.99 & 0.99 \\
\hline & $(0.52)$ & $(0.69)$ & \\
\hline $\mathrm{NH}_{3}$-emissie vanaf vloer $(\mathrm{kg} / \mathrm{jaar}$ per & 1.98 & 2.00 & 0.98 \\
\hline varken $\left.^{2)}\right)^{3)}$ & $(0.60)$ & $(0.45)$ & \\
\hline $\mathrm{NH}_{3}$-emissie voor mestaflaten $(\mathrm{kg} / \mathrm{jaar}$ per & 3.48 & 3.58 & 0.87 \\
\hline varken $\left.^{2)}\right)^{4)}$ & $(0.67)$ & $(0.86)$ & \\
\hline \multirow[t]{2}{*}{$\mathrm{NH}_{3}$-emissie $\left(\mathrm{kg} / \mathrm{jaar}\right.$ per varkensplaats $\left.{ }^{5)}\right)$} & 2.98 & 2.92 & 0.86 \\
\hline & $(0.52)$ & $(0.67)$ & \\
\hline
\end{tabular}

1) 1 ronde $\times 5$ perioden/ronde; hierbij is de $5^{e}$ periode gelijk aan de periode tussen de laatste keer aflaten van de mest tijdens de ronde en het einde van de proef (ca. 2 weken voor zowel de controle- als de proefafdeling).

2) Berekend per aanwezig varken, maar omgerekend naar jaarbasis met een leegstand van $3 \%$ (Groenestein \& Aarnink, 2008).

3) Bepaald door water in de mestput te zetten na mest aflaten.

4) Gemiddelde emissie de dag voor het aflaten van de mest.

5) Berekend per varkensplaats (aantal varkens bij opleg), omgerekend naar jaarbasis met een leegstand van $3 \%$ (Groenestein \& Aarnink, 2008). 


\section{$5 \quad$ Modelvalidatie}

\subsection{Extra inputgegevens voor de modelvalidatie}

Voor de modelvalidatie zijn, naast de input-gegevens die in paragraaf 2.1 al zijn genoemd, de volgende gegevens gebruikt voor de berekeningen:

- De afmetingen van de mestkelders en van de roostervloer en dichte vloer.

- De precieze uitvoering van de schuine wanden in de mestkelders (bij vleesvarkens en zeugen).

- De bevuiling van de dichte vloer en van de roostervloer met urine (als percentage van het totale oppervlak). Deze bevuiling werd 2x per week bepaald. Voor de tussenliggende dagen werd de waarde van de laatste meting aangehouden.

- Het ventilatiedebiet (daggemiddelden) uitgedrukt in $\mathrm{m}^{3} / \mathrm{s}$ per $\mathrm{m}^{2}$ staloppervlak. Hiermee werd de luchtsnelheid over de emitterende vloer- en kelderoppervlakken berekend.

- De temperatuur van de uitgaande stallucht (daggemiddelden). Hiermee werd de temperatuur van de emitterende vloer- en kelderoppervlakken en van de bulk mest berekend.

\subsection{Gewichtsverloop vleesvarkens en voer en wateropname}

Figuur 6 toont de $\mathrm{Y}=\mathrm{X}$ relatie tussen de berekende en de gemeten waarden van het gewicht (in $\mathrm{kg}$ ) en de cumulatieve voer- en wateropname (in $\mathrm{kg}$ ). Uit de figuren blijkt dat de berekende waarden vrijwel niet verschilden van de gemeten waarden, met regressie-coëfficiënten die vrijwel gelijk zijn aan 1 en constanten die vrijwel gelijk zijn aan 0 . De regressielijn van de cumulatieve wateropname is iets gekanteld ten opzichte van de $\mathrm{Y}=\mathrm{X}$ lijn, met een constante die iets hoger is dan 0 (4,9 L water) en een regressiecoëfficiënt die iets lager is dan $1(0,989)$. Echter ook hier is het verschil met de gemeten waarden miniem. Alle drie de curven hadden een $\mathrm{R}^{2}$ groter of gelijk aan 0,998 . In figuur 7 wordt het gemiddelde verloop van de gemeten en berekende waarden gedurende de groeiperiode weergegeven. Hieruit blijkt dat het verloop van het gewicht en voer- en wateropname goed door de curves wordt beschreven. 

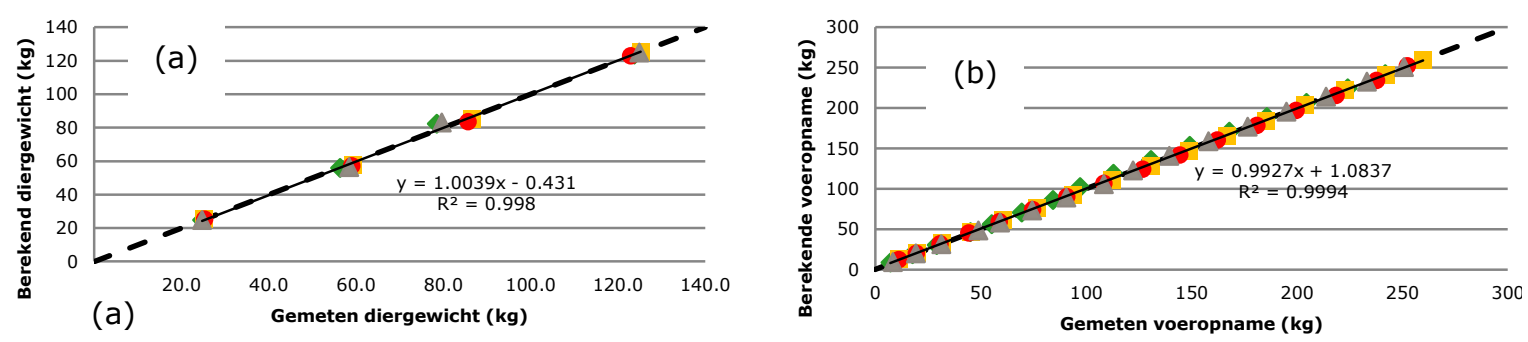

(b)

- Controle $=$ Eiwit $\quad$ Zuur

$\triangle \quad$ Combi $--Y=X$

Combi $--Y=X$

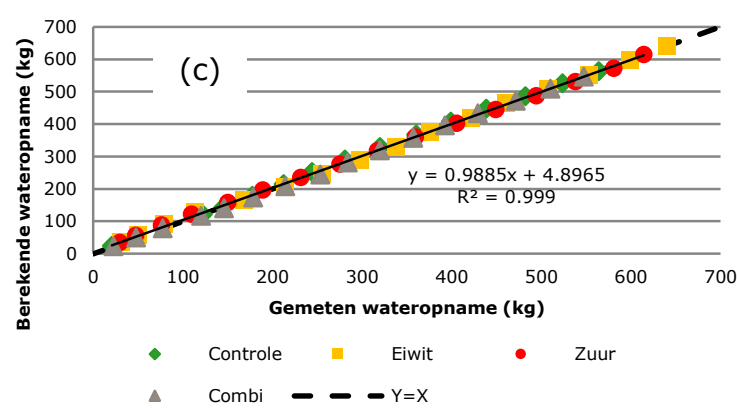

Figuur 6. Vergelijking tussen berekende $(Y)$ en gemeten $(X)$ waarden voor het cumulatieve diergewicht (a), voeropname (b) en drinkwateropname (c) ( $k g$ per vleesvarken) voor de verschillende behandelingen.

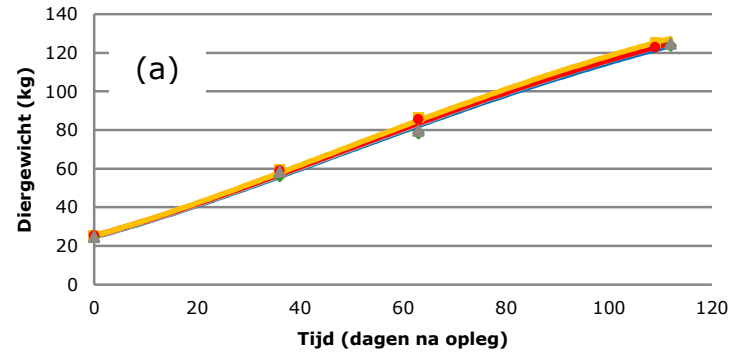

- Controle $=$ Eiwit $\bullet$ Zuur $\triangle$ Comb

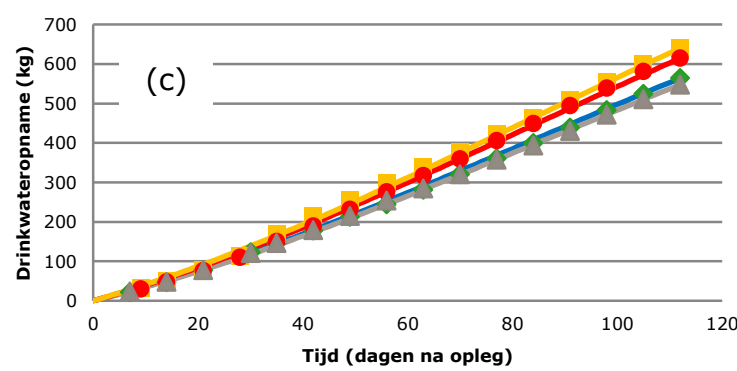

- Controle Eiwit • Zuur $\triangle$ Combi

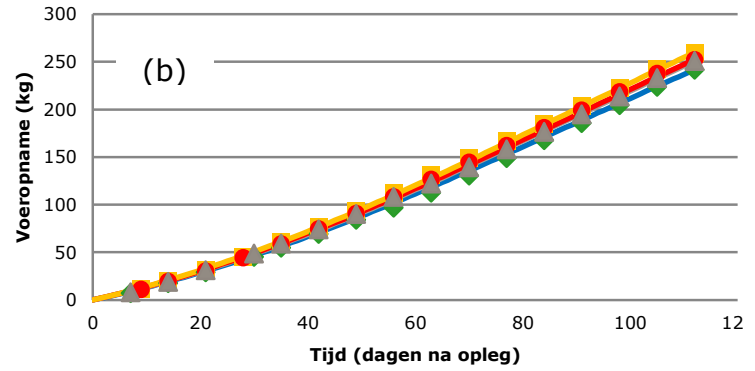

- Controle Eiwit $\bullet$ Zuur $\triangle$ Combi

Figuur 7. Gemeten (punt) en berekend (lijn) verloop van het cumulatieve diergewicht (a), voeropname (b) en drinkwateropname (c) in $\mathrm{kg}$ per vleesvarken voor de verschillende voerbehandelingen. 
In tabel 21 worden de gemiddeld gemeten diergewichten en cumulatieve voer- en wateropnames weergegeven. De berekende waarden met het model komen in het algemeen goed overeen met de gemeten waarden. De RMSE's voor diergewicht, cumulatieve voer- en drinkwateropname waren respectievelijk $1,89 \mathrm{~kg}, 1,93 \mathrm{~kg}$ en $6,1 \mathrm{~kg}$. Alhoewel de verschillen tussen berekende en gemeten drinkwateropname gering waren, waren de gepaarde verschillen wel significant verschillend van 0 $(P=0,04)$. Voor de nauwkeurigheid van de modelberekening is dit echter nauwelijks relevant.

Tabel 21

Gemiddeld gemeten en berekende diergewichten en cumulatieve voer- en wateropnames (op de meetmomenten).

\begin{tabular}{|c|c|c|c|c|c|c|c|c|}
\hline Variabele & Behand. & $n$ & Gemeten & s.d. ${ }^{1}$ & Berekend & s.d. ${ }^{1}$ & $P^{2}$ & RMSE \\
\hline Diergewicht & Controle & 3 & 86.2 & 34.4 & 87.4 & 34.2 & & \\
\hline \multirow[t]{4}{*}{$(\mathrm{kg})^{3}$} & Verl. eiwit & 3 & 90.4 & 33.2 & 89.4 & 34.0 & & \\
\hline & Zuur & 3 & 89.2 & 32.1 & 87.9 & 33.2 & & \\
\hline & Combi & 3 & 87.7 & 34.0 & 88.1 & 34.6 & & \\
\hline & Alle & 12 & 88.4 & 8.2 & 88.2 & 8.4 & 0.75 & 1.89 \\
\hline \multirow[t]{4}{*}{$(\mathrm{kg})$} & Verl. eiwit & 16 & 126 & 82 & 125 & 81 & & \\
\hline & Zuur & 16 & 123 & 80 & 122 & 79 & & \\
\hline & Combi & 16 & 121 & 78 & 121 & 78 & & \\
\hline & Alle & 64 & 121 & 77 & 121 & 77 & 0.40 & 1.93 \\
\hline \multirow[t]{4}{*}{$(\mathrm{kg})$} & Verl. eiwit & 16 & 319 & 200 & 319 & 197 & & \\
\hline & Zuur & 16 & 304 & 195 & 306 & 189 & & \\
\hline & Combi & 16 & 273 & 168 & 272 & 169 & & \\
\hline & Alle & 64 & 293 & 181 & 295 & 179 & 0.04 & 6.1 \\
\hline
\end{tabular}

${ }^{1}$ s.d. = standaard deviatie

${ }^{2} \mathrm{P}=$ kans dat gemeten en berekende warden gelijk zijn aan elkaar

${ }^{3}$ Het begingewicht is niet meegenomen als meetpunt.

\subsection{Hoeveelheid en samenstelling van de mengmest in de kelder bij vleesvarkens}

Figuur 8 toont de $\mathrm{Y}=\mathrm{X}$ relatie tussen de berekende en de gemeten waarden van de mestmassa (in $\mathrm{kg}$ ) en de berekende hoeveelheden $\mathrm{N}$-totaal en $\mathrm{NH} 4-\mathrm{N}$ in de mengmest (in $\mathrm{kg}$ ). Voor de mestmassa verschilde de constante niet significant van 0 . De regressiecoëfficiënt verschilde wel significant van 1. Voor N-totaal NH4-N in de mengmest verschilden de constanten niet significant van 0 . De regressiecoëfficiënten verschilden wel significant van 1 . De gemeten waarden worden vooral bij de hogere waarden onderschat. In figuur 9 worden de $\mathrm{Y}=\mathrm{X}$ relaties weergegeven voor de gehalten aan $\mathrm{N}$ totaal en NH4-N in de bulk mengmest. Voor deze relaties verschilden de constanten in de mengmest niet significant van 0 . Voor $\mathrm{N}$-totaal gehalte verschilde de regressiecoëfficiënt niet significant van 1 ; voor NH4-N gehalte was dit wel het geval. Hiervoor geldt dat gemeten waarden vooral bij de hogere gehalten worden onderschat.

In figuur 10 worden de $\mathrm{Y}=\mathrm{X}$ relaties weergegeven voor de $\mathrm{pH}$ van de bulk mengmest. Voor de berekende $\mathrm{pH}$ uit de gemeten samenstelling van de mest (NH4-N, TIC en azijnzuurgehalte) was de constante niet significant verschillend van 0 en de regressiecoëfficiënt niet van 1 . Voor de berekende $\mathrm{pH}$ uit de berekende samenstelling van de mest (uit de inputgegevens van het model) waren de constante en de regressiecoëfficiënt wel significant verschillend van respectievelijk 0 en 1 . Lage waarden worden overschat en hoge waarden worden onderschat. In figuur 11a wordt de relatie weergegeven tussen de gemeten $\mathrm{pH}$ op $0,5 \mathrm{~cm}$ diepte in de mest en de berekende $\mathrm{pH}$ van de grenslaag op basis van gemeten NH4-N, TIC (totaal anorganisch koolstof) en azijnzuur gehalten in de mengmest. Uit deze figuur blijkt dat de $\mathrm{pH}$ van de grenslaag van de mest nog zeer sterk wordt 
afgevlakt ten opzichte van de $\mathrm{pH}$ op $0,5 \mathrm{~cm}$ diepte. Figuur $11 \mathrm{~b}$ is opgenomen om te laten zien dat het model de $\mathrm{pH}$ van de bovenste laag van de mest vooral bij hoge waarden enigszins onderschat. Uit deze figuur is op te maken dat de (berekende) $\mathrm{pH}$ van de bovenste laag van de mengmest varieert in een zeer beperkte bandbreedte $(<0,3 \mathrm{pH}$ eenheden).
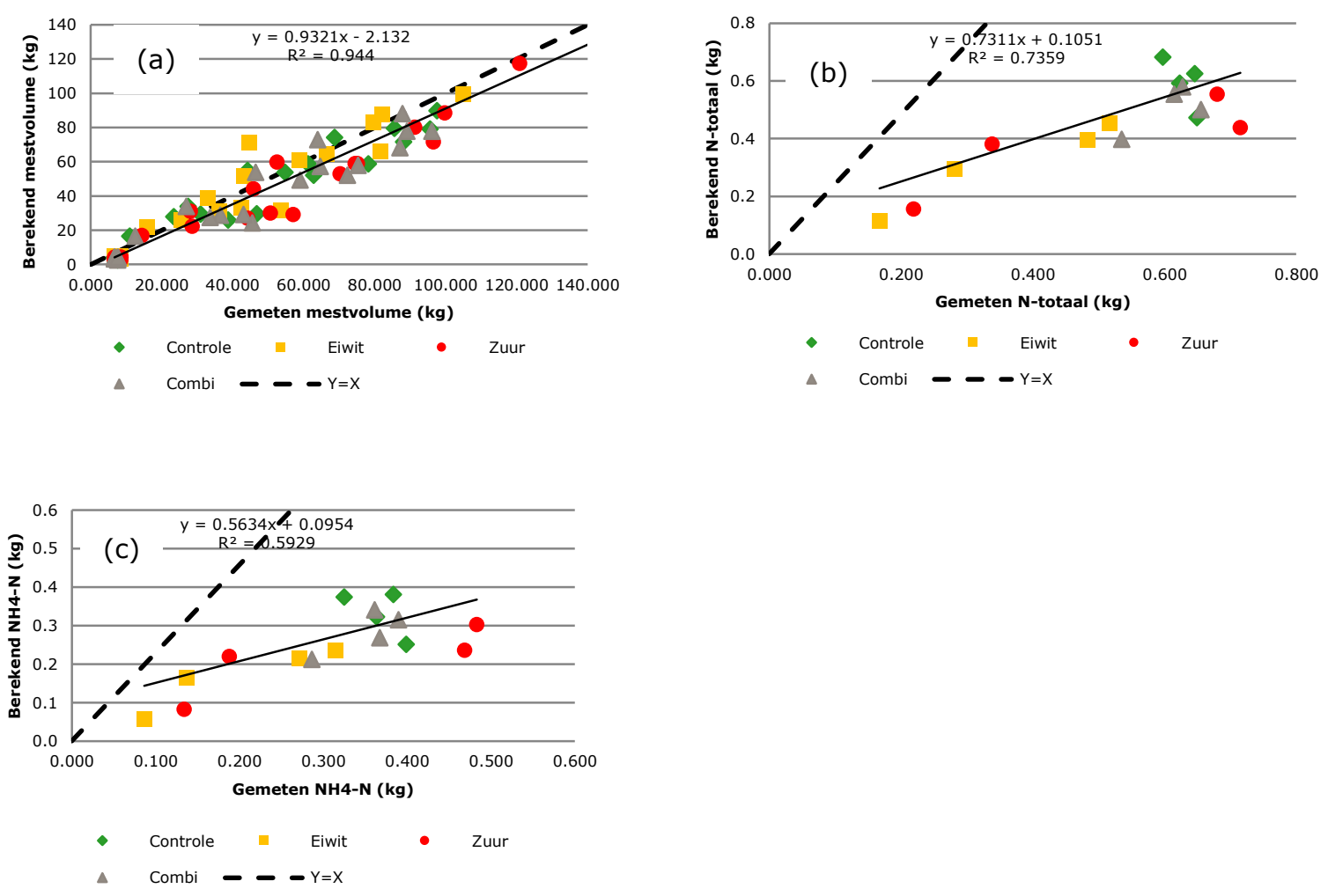

Figuur 8. Vergelijking tussen berekende $(Y)$ en gemeten $(X)$ waarden voor mestvolume (a), en hoeveelheid $\mathrm{N}$-totaal (b) en $\mathrm{NH} 4-\mathrm{N}$ (c) in de mengmest ( $\mathrm{kg}$ per varken in de verschillende meetperioden) voor de verschillende behandelingen.
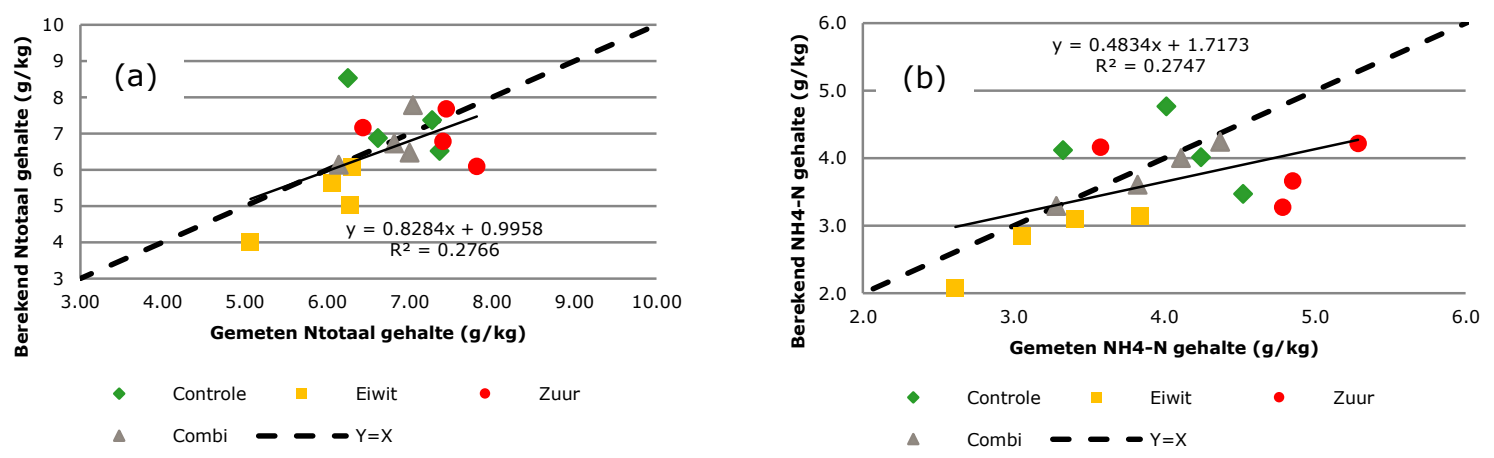

Figuur 9. Vergelijking tussen berekende $(Y)$ en gemeten $(X)$ waarden voor $N$-totaal gehalte (a) en NH4$N$ gehalte $(b)$ in de bulk mengmest $(\mathrm{g} / \mathrm{kg})$ voor de verschillende behandelingen. 

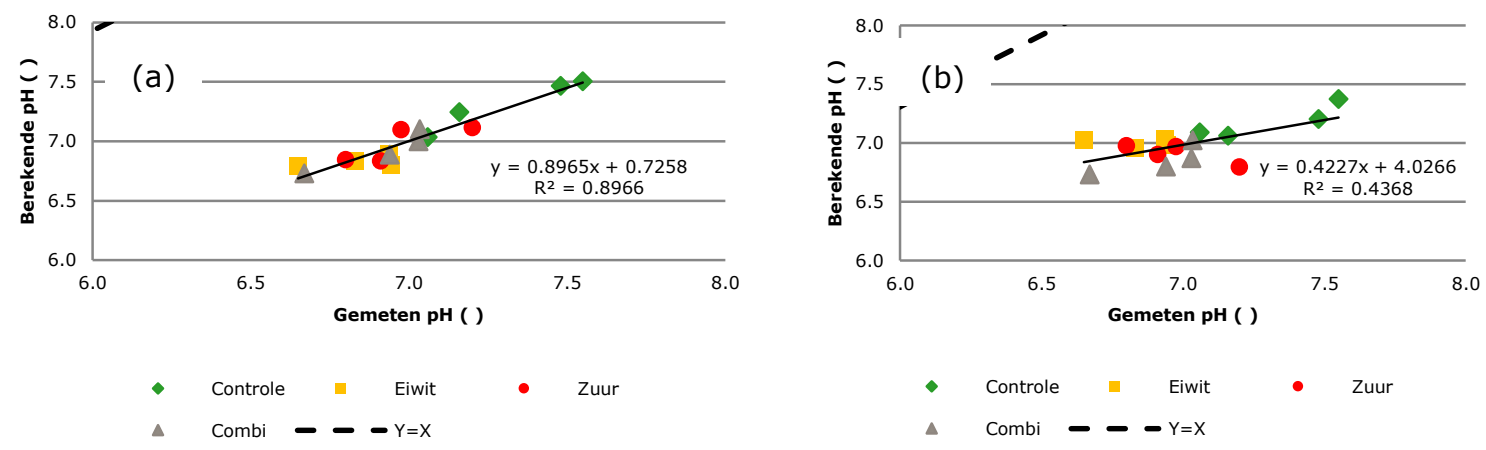

Figuur 10. Vergelijking tussen berekende $(Y)$ en gemeten $(X)$ waarden voor de $p H$ van de bulk mest. (a) berekende $\mathrm{pH}$ op basis van gemeten NH4-N, TIC (totaal anorganisch koolstof) en azijnzuur gehalten in de mengmest; (b) berekende $\mathrm{pH}$ op basis van berekende (op basis van inputgegevens van het model) NH4-N en azijnzuur gehalten in de mengmest en krijt-toevoeging $\left(\mathrm{CaCO}_{3}\right)$ aan het voer.
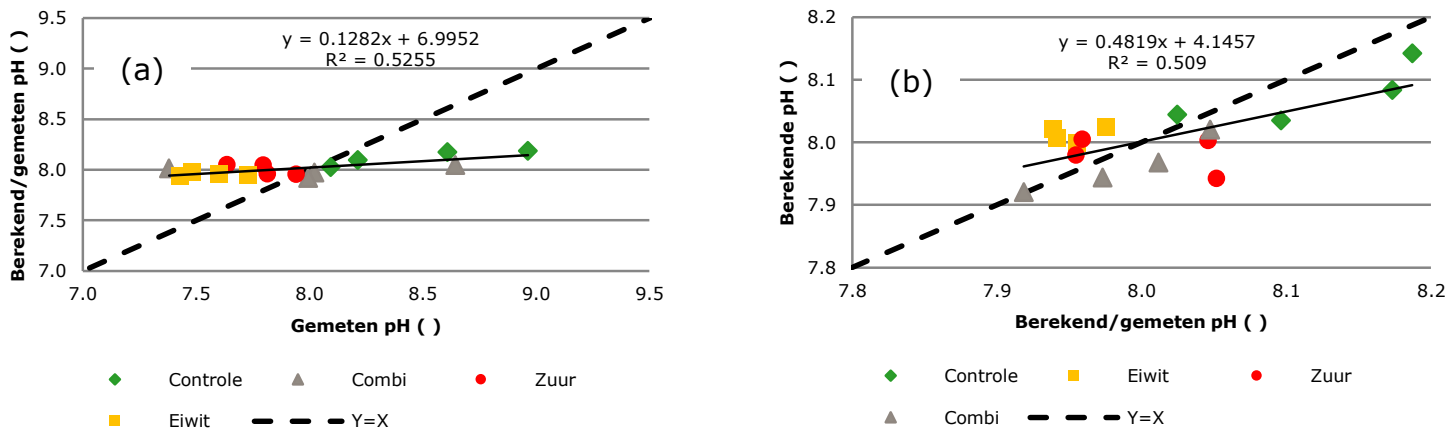

Figuur 11. Vergelijking tussen (a) berekende $\mathrm{pH}$ van de grenslaag van de mest, op basis van gemeten $\mathrm{NH4-N,} \mathrm{TIC} \mathrm{(totaal} \mathrm{anorganisch} \mathrm{koolstof)} \mathrm{en} \mathrm{azijnzuur} \mathrm{gehalten} \mathrm{in} \mathrm{de} \mathrm{mengmest}(Y)$ en de gemeten $\mathrm{pH}$ op 0,5 cm diepte $(X)$; (b) berekende $\mathrm{pH}$ op basis van input gegevens van het model $(Y)$ en berekende

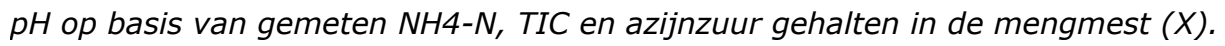

In tabel 22 worden de gemeten en berekende waarden van het mestvolume en de gehalten in de mengmest weergegeven. Het mestvolume werd gemiddeld iets lager ingeschat dan gemeten; dit verschil was echter niet significant. De RMSE was $0,77 \mathrm{~kg}$. Het ds- en as-gehalte van de mengmest werden goed berekend, met geringe verschillen met gemeten waarden. De RMSE was respectievelijk 24,0 en $2,73 \mathrm{~g} / \mathrm{kg}$ voor ds- en as-gehalte. Het totaal $\mathrm{N}$-gehalte $(P=0,03)$ en het NH4-N gehalte $(\mathrm{P}<0,001)$ werden lager berekend dan gemeten. Dit gold ook voor het NH4-N gehalte van de bovenste laag van de mengmest $(P=0,02)$. De berekende gehalten voor $K$ en $P$ komen goed overeen met de gemeten waarden. Het $\mathrm{Ca}$ gehalte werd gemiddeld iets hoger berekend dan gemeten $(P=0,04)$. Het vluchtig vetzuurgehalte van de mengmest werd iets lager berekend dan gemeten $(P=0,08)$. De $\mathrm{pH}$ van de bulk mest en van de bovenlaag van de mest werd gemiddeld vergelijkbaar berekend als gemeten. Voor de afzonderlijke behandelingen zijn wel verschillen te constateren. 
Tabel 22

Gemiddeld gemeten en berekend volume en samenstelling van de mengmest (op de meetmomenten) bij de vleesvarkens.

\begin{tabular}{|c|c|c|c|c|c|c|c|c|}
\hline Variabele & Behand. & n & Gemeten & s.d. ${ }^{1}$ & Berekend & s.d. ${ }^{1}$ & $\mathbf{P}^{2}$ & RMSE \\
\hline Mestvolume & Controle & 5 & 3.87 & 0.74 & 3.56 & 0.50 & & \\
\hline \multirow[t]{4}{*}{ (kg/dag) } & Verl. eiwit & 5 & 3.30 & 1.11 & 3.95 & 0.52 & & \\
\hline & Zuur & 5 & 3.42 & 1.28 & 3.42 & 0.60 & & \\
\hline & Combi & 5 & 4.09 & 0.91 & 3.46 & 0.49 & & \\
\hline & Alle & 20 & 3.67 & 1.00 & 3.60 & 0.53 & 0.65 & 0.73 \\
\hline Ds-gehalte & Controle & 4 & 97.7 & 9.2 & 97.2 & 16.4 & & \\
\hline \multirow[t]{4}{*}{$(\mathrm{g} / \mathrm{kg})$} & Verl. eiwit & 4 & 93.2 & 8.9 & 76.9 & 17.7 & & \\
\hline & Zuur & 4 & 86.4 & 15.9 & 91.2 & 15.5 & & \\
\hline & Combi & 4 & 104.5 & 10.4 & 99.2 & 21.7 & & \\
\hline & Alle & 16 & 95.4 & 12.3 & 91.1 & 18.4 & 0.49 & 23.9 \\
\hline As-gehalte & Controle & 4 & 18.9 & 1.6 & 19.8 & 1.3 & & \\
\hline \multirow[t]{4}{*}{$(\mathrm{g} / \mathrm{kg})$} & Verl. eiwit & 4 & 19.3 & 1.6 & 18.9 & 1.3 & & \\
\hline & Zuur & 4 & 18.8 & 2.4 & 19.2 & 1.4 & & \\
\hline & Combi & 4 & 19.7 & 1.4 & 19.2 & 0.8 & & \\
\hline & Alle & 16 & 19.2 & 1.6 & 19.3 & 1.2 & 0.84 & 2.42 \\
\hline N-totaal & Controle & 4 & 6.88 & 0.53 & 7.32 & 0.88 & & \\
\hline \multirow[t]{4}{*}{$(\mathrm{g} / \mathrm{kg})$} & Verl. eiwit & 4 & 5.93 & 0.58 & 5.19 & 0.90 & & \\
\hline & Zuur & 4 & 7.28 & 0.59 & 6.93 & 0.67 & & \\
\hline & Combi & 4 & 6.75 & 0.42 & 6.77 & 0.71 & & \\
\hline & Alle & 16 & 6.71 & 0.70 & 6.55 & 1.10 & 0.52 & 0.92 \\
\hline $\mathrm{NH} 4-\mathrm{N}$ & Controle & 4 & 4.03 & 0.51 & 4.09 & 0.53 & & \\
\hline \multirow[t]{4}{*}{$(\mathrm{g} / \mathrm{kg})$} & Verl. eiwit & 4 & 3.23 & 0.52 & 2.79 & 0.50 & & \\
\hline & Zuur & 4 & 4.62 & 0.73 & 3.83 & 0.45 & & \\
\hline & Combi & 4 & 3.90 & 0.47 & 3.79 & 0.42 & & \\
\hline & Alle & 16 & 3.94 & 0.72 & 3.62 & 0.66 & 0.08 & 0.73 \\
\hline $\mathrm{NH} 4-\mathrm{N}$ & Controle & 4 & 3.29 & 1.27 & 2.72 & 0.36 & & \\
\hline bovenlaag & Verl. eiwit & 4 & 2.33 & 0.78 & 1.85 & 0.33 & & \\
\hline mengmest & Zuur & 4 & 2.42 & 1.51 & 2.54 & 0.29 & & \\
\hline \multirow[t]{2}{*}{$(\mathrm{g} / \mathrm{kg})$} & Combi & 4 & 2.91 & 0.80 & 2.51 & 0.28 & & \\
\hline & Alle & 16 & 2.74 & 1.09 & 2.41 & 0.44 & 0.26 & 1.13 \\
\hline K-gehalte & Controle & 4 & 3.99 & 0.39 & 4.04 & 0.08 & & \\
\hline \multirow[t]{4}{*}{$(\mathrm{g} / \mathrm{kg})$} & Verl. eiwit & 4 & 3.70 & 0.10 & 3.47 & 0.30 & & \\
\hline & Zuur & 4 & 4.19 & 0.18 & 4.05 & 0.22 & & \\
\hline & Combi & 4 & 4.08 & 0.45 & 4.13 & 0.18 & & \\
\hline & Alle & 16 & 3.99 & 0.34 & 3.92 & 0.33 & 0.47 & 0.35 \\
\hline P-gehalte & Controle & 4 & 1.32 & 0.12 & 1.42 & 0.40 & & \\
\hline \multirow[t]{4}{*}{$(\mathrm{g} / \mathrm{kg})$} & Verl. eiwit & 4 & 1.24 & 0.09 & 0.99 & 0.40 & & \\
\hline & Zuur & 4 & 1.18 & 0.15 & 1.24 & 0.42 & & \\
\hline & Combi & 4 & 1.36 & 0.17 & 1.38 & 0.44 & & \\
\hline & Alle & 16 & 1.27 & 0.14 & 1.26 & 0.41 & 0.85 & 0.35 \\
\hline Ca-gehalte & Controle & 4 & 1.90 & 0.14 & 2.21 & 0.14 & & \\
\hline \multirow[t]{4}{*}{$(\mathrm{g} / \mathrm{kg})$} & Verl. eiwit & 4 & 2.25 & 0.52 & 2.73 & 0.86 & & \\
\hline & Zuur & 4 & 1.85 & 0.65 & 1.96 & 0.26 & & \\
\hline & Combi & 4 & 2.25 & 0.38 & 2.62 & 0.47 & & \\
\hline & Alle & 16 & 2.06 & 0.46 & 2.38 & 0.46 & 0.04 & 0.63 \\
\hline$V V Z^{3}$ & Controle & 4 & 6.56 & 1.86 & 7.26 & 2.66 & & \\
\hline \multirow[t]{4}{*}{$(\mathrm{g} / \mathrm{kg})$} & Verl. eiwit & 4 & 6.79 & 1.91 & 5.76 & 1.33 & & \\
\hline & Zuur & 4 & 7.18 & 2.05 & 5.98 & 1.17 & & \\
\hline & Combi & 4 & 9.35 & 0.90 & 7.07 & 2.58 & & \\
\hline & Alle & 16 & 7.47 & 1.93 & 6.52 & 1.96 & 0.08 & 2.18 \\
\hline
\end{tabular}




\begin{tabular}{|c|c|c|c|c|c|c|c|c|}
\hline Variabele & Behand. & $n$ & Gemeten & S.d. ${ }^{1}$ & Berekend & s.d. ${ }^{1}$ & $\mathbf{P}^{2}$ & RMSE \\
\hline $\mathrm{pH}$ & Controle & 4 & 7.31 & 0.24 & 7.19 & 0.14 & & \\
\hline \multirow[t]{4}{*}{ mest bulk } & Verl. eiwit & 4 & 6.84 & 0.14 & 7.00 & 0.04 & & \\
\hline & Zuur & 4 & 6.97 & 0.17 & 6.91 & 0.08 & & \\
\hline & Combi & 4 & 6.92 & 0.17 & 6.86 & 0.12 & & \\
\hline & Alle & 16 & 7.01 & 0.25 & 6.99 & 0.16 & 0.66 & 0.18 \\
\hline $\mathrm{pH}$ mest & Controle & 4 & 8.16 & 0.39 & 8.08 & 0.05 & & \\
\hline bovenlaag & Verl. eiwit & 4 & 7.70 & 0.22 & 8.01 & 0.01 & & \\
\hline \multirow[t]{3}{*}{ (filters) } & Zuur & 4 & 7.93 & 0.16 & 7.98 & 0.03 & & \\
\hline & Combi & 4 & 7.82 & 0.26 & 7.94 & 0.02 & & \\
\hline & Alle & 16 & 7.91 & 0.30 & 8.01 & 0.06 & 0.20 & 0.29 \\
\hline $\mathrm{pH}$ mest & Controle & 4 & 8.47 & 0.40 & 8.08 & 0.05 & & \\
\hline bovenlaag & Verl. eiwit & 4 & 7.56 & 0.13 & 8.01 & 0.01 & & \\
\hline \multirow[t]{3}{*}{$(0,5 \mathrm{~cm})$} & Zuur & 4 & 7.80 & 0.13 & 7.98 & 0.03 & & \\
\hline & Combi & 4 & 8.01 & 0.52 & 7.96 & 0.04 & & \\
\hline & Alle & 16 & 7.96 & 0.46 & 8.01 & 0.05 & 0.66 & 0.42 \\
\hline
\end{tabular}

${ }^{1}$ s.d. = standaard deviatie

${ }^{2} \mathrm{P}=$ kans dat gemeten en berekende waarden gelijk zijn aan elkaar

${ }^{3} \mathrm{VVZ}=$ totaal gehalte aan vluchtige vetzuren

\subsection{Samenstelling van de urineplassen op de vloer bij vleesvarkens}

Figuur 12 toont de $\mathrm{Y}=\mathrm{X}$ relatie tussen de berekende en de gemeten waarden van het ammonium- $\mathrm{N}$ gehalte $(\mathrm{g} / \mathrm{kg})$ en de $\mathrm{pH}(-)$ van de urineplassen op de vloer van de varkenshokken. De constanten in de regressielijnen van $\mathrm{NH} 4-\mathrm{N}$ gehalte en $\mathrm{pH}$ verschilden significant van 0 . De regressiecoëfficiënten verschilden significant van 1 . Net als bij vorige figuren blijken lage waarden overschat en hoge waarden onderschat te worden. Dit geeft een veel geringere variatie in de berekeningen ten opzichte van de metingen.
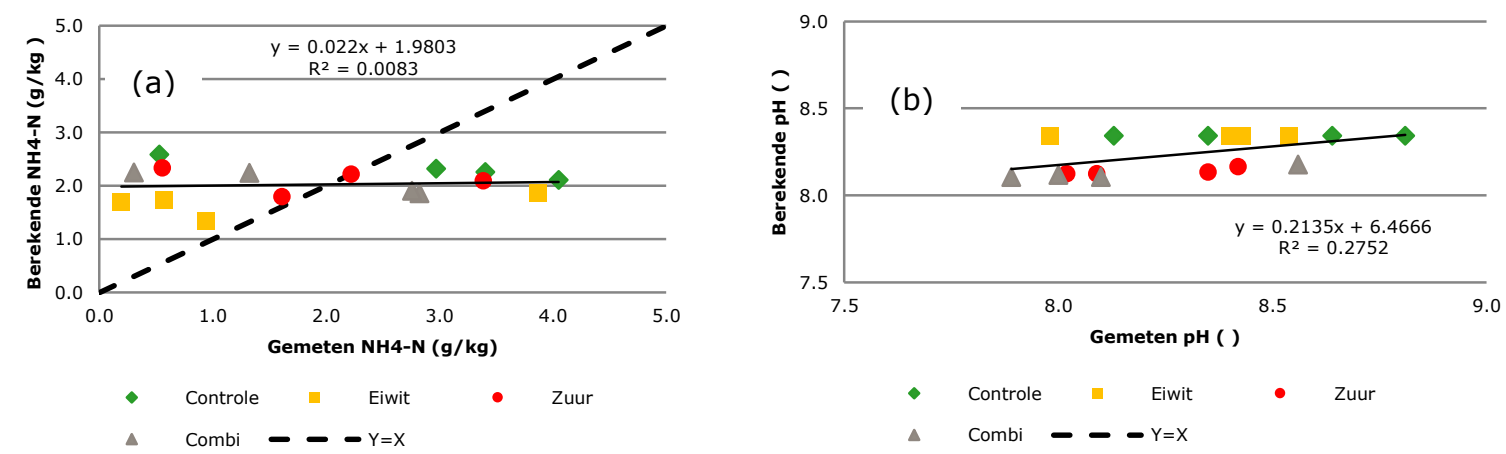

Figuur 12. Vergelijking tussen berekende $(Y)$ en gemeten $(X)$ waarden (m.b.v. de filtermethode) voor NH4-N gehalte $(\mathrm{g} / \mathrm{kg} ; \mathrm{a})$ en $\mathrm{pH}(-; b)$ van de urineplas voor de verschillende behandelingen.

In tabel 23 wordt de gemeten en berekende samenstelling van de urineplassen gegeven. Hieruit blijkt dat het $\mathrm{N}$-totaal gehalte significant lager werd berekend dan gemeten $(P=0,009)$, met een RMSE van $3,7 \mathrm{~g} / \mathrm{kg}$ ). Het NH4-N gehalte van de urineplas werd gemiddeld iets lager ingeschat, maar dit verschil was niet significant; de RMSE was $1,3 \mathrm{~g} / \mathrm{kg}$. De $\mathrm{pH}$ van de urineplas werd hoger ingeschat dan gemeten, zowel via de directe methode met de $\mathrm{pH}$ meter $(P=0,02)$ als met de filtermethode $(P=0,04)$. 
Tabel 23

Gemiddeld gemeten en berekende samenstelling van de urineplassen (op de meetmomenten) bij de vleesvarkens.

\begin{tabular}{|c|c|c|c|c|c|c|c|c|}
\hline Variabele & Behand. & n & Gemeten & s.d. ${ }^{1}$ & Berekend & s.d. ${ }^{1}$ & $P^{2}$ & RMSE \\
\hline Verse urine & Verl. eiwit & 4 & 6.92 & 5.80 & 5.48 & 0.78 & & \\
\hline \multirow[t]{2}{*}{$(\mathrm{g} / \mathrm{kg})$} & Zuur & 4 & 8.17 & 1.94 & 7.10 & 0.78 & & \\
\hline & Combi & 4 & 8.14 & 2.52 & 6.98 & 0.70 & & \\
\hline urineplas & Verl. eiwit & 4 & 1.39 & 1.68 & 1.62 & 0.24 & & \\
\hline \multirow[t]{2}{*}{$(\mathrm{g} / \mathrm{kg})$} & Zuur & 4 & 1.94 & 1.18 & 2.10 & 0.24 & & \\
\hline & Combi & 4 & 1.80 & 1.22 & 2.06 & 0.21 & & \\
\hline direct & Zuur & 4 & 7.83 & 0.44 & 8.14 & 0.02 & & \\
\hline \multirow[t]{2}{*}{$(-)$} & Combi & 4 & 7.76 & 0.55 & 8.13 & 0.03 & & \\
\hline & Alle & 16 & 7.99 & 0.44 & 8.24 & 0.11 & 0.02 & 0.46 \\
\hline $\mathrm{pH}$ & Controle & 4 & 8.48 & 0.30 & 8.48 & 0.00 & & \\
\hline urineplas & Verl. eiwit & 4 & 8.34 & 0.25 & 8.48 & 0.00 & & \\
\hline (filters) & Zuur & 4 & 8.22 & 0.19 & 8.41 & 0.01 & & \\
\hline \multirow[t]{2}{*}{$(-)$} & Combi & 4 & 8.14 & 0.29 & 8.40 & 0.01 & & \\
\hline & Alle & 16 & 8.29 & 0.27 & 8.44 & 0.04 & 0.04 & 0.28 \\
\hline
\end{tabular}

${ }^{1}$ s.d. = standaard deviatie

$2 \mathrm{P}=$ kans dat gemeten en berekende waarden gelijk zijn aan elkaar

\subsection{Ammoniakemissie bij vleesvarkens}

In figuur 13 wordt het gemeten en het berekend verloop van de ammoniakemissie getoond per aanwezig varken (omgerekend naar jaarbasis met een leegstand van 3\%) voor de 4 afdelingen met de verschillende voerbehandelingen. Uit deze figuur blijkt dat het verloop van de ammoniakemissie in het algemeen redelijk goed wordt voorspeld. Alleen wordt de ammoniakemissie tussen de 60 en 100 dagen behoorlijk onderschat in de controle- en in de combi-afdeling. Dit lijkt samen te hangen met een voerovergang op dag 63, waarbij de pH van de bulk mest onderschat lijkt te worden (zie figuur 10b). De figuur laat een aantal duidelijke dalingen in de ammoniakemissie zien; dit zijn de momenten waarop de mest is afgelaten en de mestkelders gedurende ongeveer 2 dagen vol zijn gezet met water. De vrij sterke stijging van de ammoniakemissie aan het eind van de ronde heeft te maken met het feit dat de eerste dieren 2 weken eerder zijn afgeleverd dan de laatste dieren. De emissies zijn steeds weergegeven per aanwezig varken. In figuur 14 worden de $Y=X$ figuren weergegeven voor de verschillende voerbehandelingen/afdelingen. Uit de analyse van deze figuren blijkt dat de constante van de regressielijnen voor voerbehandelingen eiwit en zuur significant verschilde van 0 . Dit was niet het geval voor de constante van de controle en combi behandelingen. De regressie coëfficiënt verschilde voor alle behandelingen significant van 1,0 . In alle gevallen was deze kleiner dan 1 . Dit betekent dat vooral de hogere waarden onderschat worden met het model.

In figuur 15 wordt het berekende verloop van de ammoniakemissie vanaf de vloer gegeven per aanwezig varken (omgerekend naar jaarbasis met een leegstand van 3\%). Per afdeling is dit op 4 momenten gemeten na het aflaten van de mest en het vol zetten van de mestkelder met water. Uit deze figuur blijkt dat de vloeremissie in het algemeen vrij goed wordt geschat. Hierbij dient opgemerkt te worden dat de emissie van de schuine wanden in de mestkelder bij de vloeremissie is gerekend. Dit is ook de reden dat de berekende vloeremissie steeds een duidelijke verlaging laat zien op de momenten van mestaflaten en het vullen van de mestkelder met water. Op dat moment is namelijk verondersteld dat de wandemissie in de kelder nul is. De mestkelders werden niet helemaal vol gezet met water, daarom is het waarschijnlijk dat er toch nog een deel van de kelderwand emitteert. 

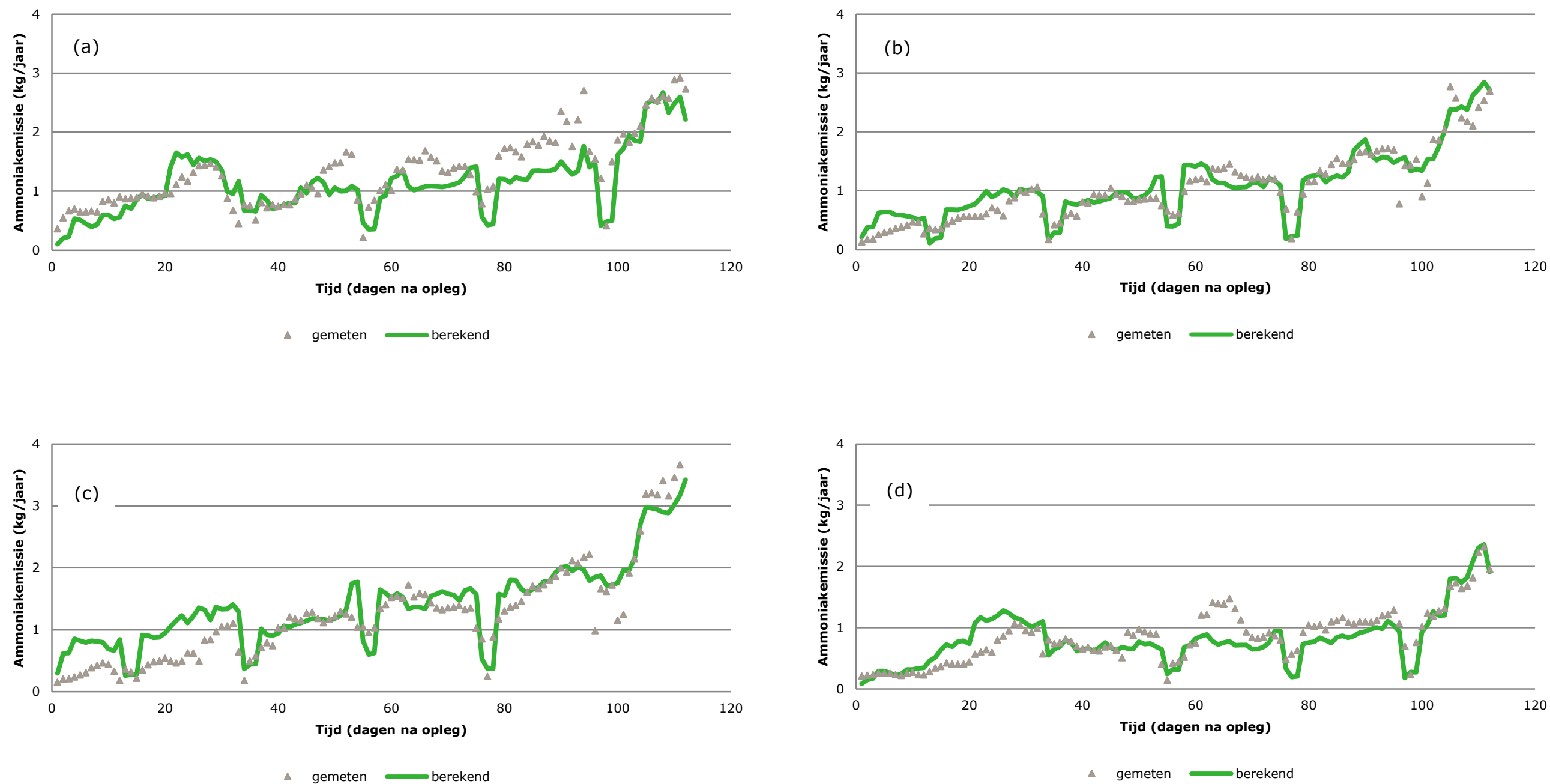

Figuur 13. Verloop van de ammoniakemissie ( $\mathrm{kg} / \mathrm{jaar}$ per aanwezig varken) in de 4 vleesvarkensafdelingen met de verschillende voerbehandelingen; (a) controle (afd 11); b) eiwit (afd 10); c) zuur (afd 9); d) combi (afd 12). 


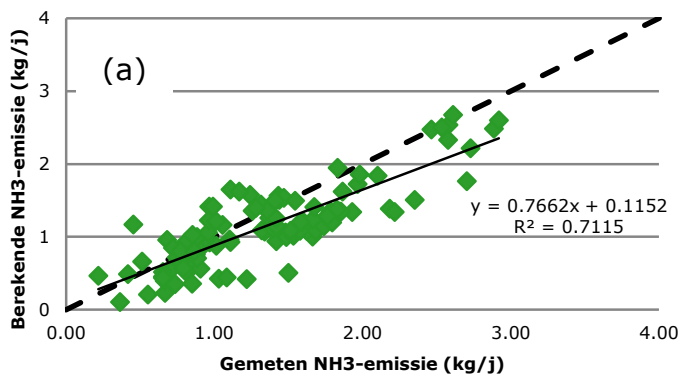

- Controle $--\mathrm{Y}=\mathrm{X}$

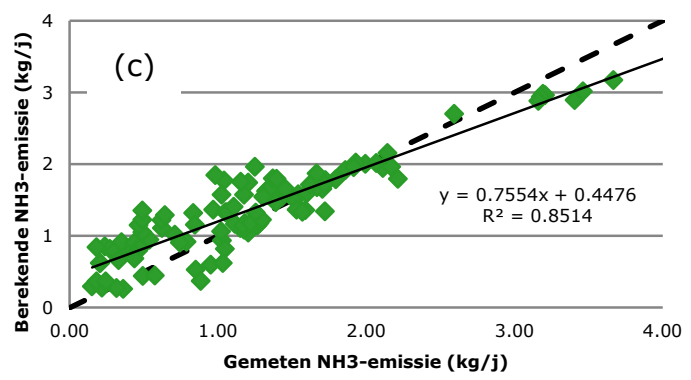

- Zuur $-2 \mathrm{Y}=\mathrm{X}$

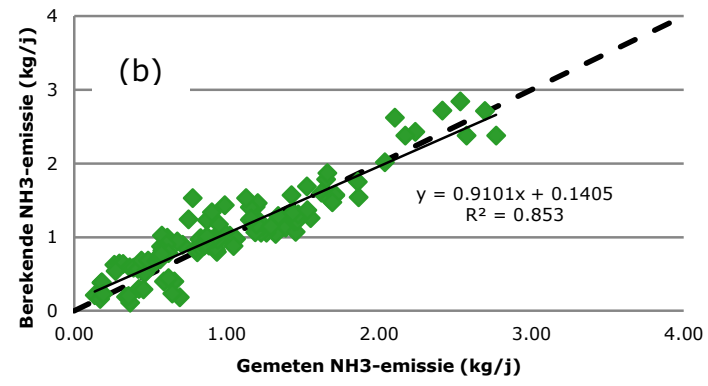

- Eiwit - $-Y=X$

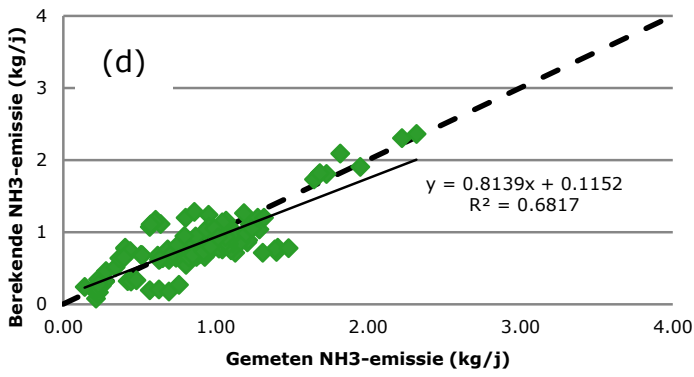

- Combi - - $\mathrm{Y}=\mathrm{X}$

Figuur 14. Vergelijking tussen berekende $(Y)$ en gemeten $(X)$ waarden voor de ammoniakemissie ( $\mathrm{kg} / \mathrm{jaar}$ per aanwezig varken) voor de 4 voerbehandelingen; (a) controle (afd 11); b) verlaagd eiwit (afd 10); c) zuur (afd 9); d) combi (afd 12). 

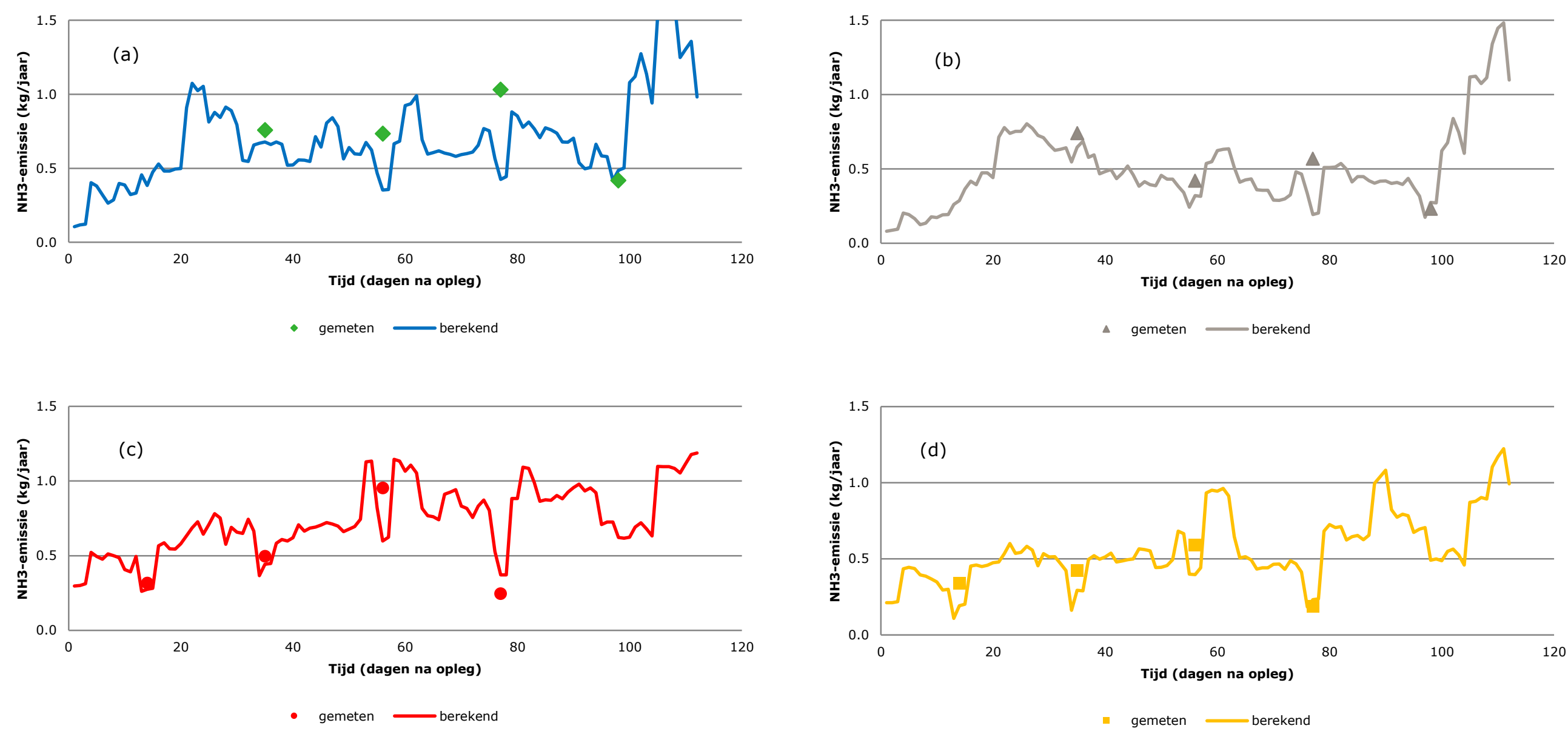

Figuur 15. Berekend (lijn) en gemeten (punten) verloop van de ammoniakemissie vanaf de vloer (kg/jaar per aanwezig varken) in de 4 vleesvarkensafdelingen met de verschillende voerbehandelingen; (a) controle (afd 11); b) verlaagd eiwit (afd 10); c) zuur (afd 9); d) combi (afd 12). 
In tabel 24 worden de gemeten en berekende ammoniakemissies gegeven voor de verschillende behandelingen. Hieruit blijkt dat de berekende emissies gemiddeld vergelijkbaar waren met de gemeten emissies $(P=0,38)$. Wel zijn er enige verschillen per behandeling te constateren. De ammoniakemissie uit de controle-afdeling is enigszins onderschat, terwijl de emissie uit de zuurafdeling is overschat. De RMSE voor het verschil tussen berekende en gemeten waarden was 0,31 $\mathrm{kg} / \mathrm{jaar}$ (dag-variaties omgerekend naar jaaremissies).

De bijdrage van de vloer aan de totale ammoniakemissie werd gemiddeld $0,14 \mathrm{~kg} / \mathrm{jaar}(P=0,011)$ lager ingeschat dan gemeten. Deze onderschatting gold voor alle behandelingen. De berekende totale emissie op de dag voordat de mestkelders werden geleegd was gemiddeld vergelijkbaar met de gemeten emissie $(P=0,37))$.

\section{Tabel 24}

Gemiddeld gemeten en berekende ammoniakemissies bij vleesvarkens (in kg/jaar per aanwezig $\operatorname{varken}^{1}$ ).

\begin{tabular}{|c|c|c|c|c|c|c|c|c|}
\hline Variabele & Behand. & n & Gemeten & s.d. ${ }^{1}$ & Berekend & s.d. ${ }^{2}$ & $P^{3}$ & RMSE \\
\hline totaal & Verl. eiwit & 112 & 1.04 & 0.59 & 1.09 & 0.58 & & \\
\hline dagelijks & Zuur & 112 & 1.25 & 0.81 & 1.39 & 0.67 & & \\
\hline gemeten & Combi & 112 & 0.86 & 0.44 & 0.81 & 0.44 & & \\
\hline vloer & Verl. eiwit & 4 & 0.39 & 0.17 & 0.28 & 0.09 & & \\
\hline $1 x / 3 w k n^{4}$ & Zuur & 4 & 0.50 & 0.32 & 0.42 & 0.14 & & \\
\hline gemeten & Combi & 4 & 0.49 & 0.22 & 0.36 & 0.20 & & \\
\hline $1 \times / 3 w k n^{5}$ & Zuur & 4 & 1.00 & 0.46 & 1.37 & 1.36 & & \\
\hline \multirow[t]{2}{*}{ gemeten } & Combi & 4 & 1.01 & 0.19 & 0.93 & 0.92 & & \\
\hline & Alle & 16 & 1.06 & 0.37 & 1.12 & 0.35 & 0.37 & 0.28 \\
\hline
\end{tabular}

${ }^{1}$ Berekend per aanwezig varken, maar omgerekend naar jaarbasis met een leegstand van $3 \%$.

${ }^{2}$ s.d. = standaard deviatie

${ }^{3} \mathrm{P}=$ kans dat gemeten en berekende waarden gelijk zijn aan elkaar (bij $\mathrm{P}<0.05$ significant verschil)

${ }^{4}$ Steeds gemeten nadat de mest is afgelaten en de mestkelder vol gezet is met water.

${ }^{5}$ Steeds gemeten een dag voor het aflaten van de mest

\subsection{Gemeten en berekende behandelingseffecten bij vleesvarkens}

In tabel 25 worden de gemeten en berekende effecten gegeven van de verschillende voerbehandelingen. Uit deze tabel blijkt dat de effecten van het eiwitgehalte van het voer goed worden ingeschat met het rekenmodel, zowel in absolute emissies, als in relatieve emissies. Het effect van het zuur wordt minder goed ingeschat. Dit wordt waarschijnlijk vooral veroorzaakt door het feit dat het effect van benzoëzuur-toevoeging aan het voer niet wordt meegenomen in de berekening van de $\mathrm{pH}$ van de mengmest, wel voor berekening van de $\mathrm{pH}$ van de urineplassen. Het effect van de zuurbehandeling op de emissie vanaf de vloer wordt daarom wel beter ingeschat. In de berekening van de $\mathrm{pH}$ van de mest wordt wel het effect van de vervanging van Ca-carbonaat (krijt) door Caformiaat meegenomen. Uit de tabel blijkt dat er grote verschillen zijn in de berekende emissies per $\mathrm{m}^{2}$ emitterend oppervlak. De hoogste emissies worden berekend voor het emitterend oppervlak van urineplassen op een betonnen vloer (dichte vloer + betonnen roostervloer). De berekende emissies per $\mathrm{m}^{2}$ emitterend oppervlak voor de mestkelder achter en voor een metalen driekantrooster zijn vergelijkbaar. De laagste emissies per $\mathrm{m}^{2}$ emitterend oppervlak worden berekend voor de mestkelder voor, waar de mest is verdund met water. 
Tabel 25

Gemeten en berekende effecten van de verschillende voerbehandelingen op de ammoniakemissie bij vleesvarkens. ( $n=20$ perioden; 5 perioden per afdeling; na elke periode werd de mest afgelaten).

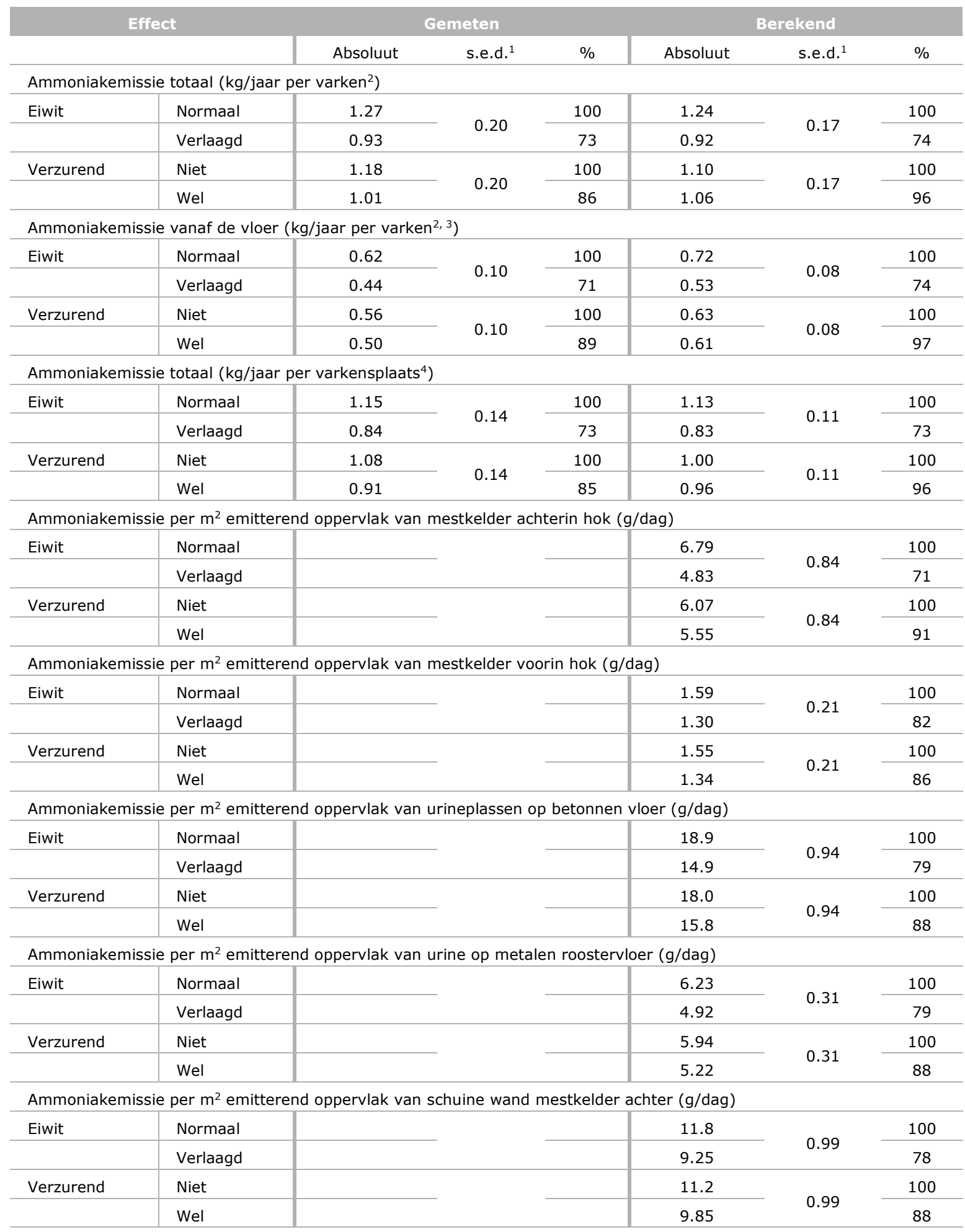

${ }^{1}$ s.e.d. $=$ standaard error of difference

2 Per aanwezig varken in de afdeling; omgerekend naar jaarbasis met een leegstand van $3 \%$.

${ }^{3}$ De metingen zijn steeds gedaan na het mest aflaten, met water in de mestput $(n=16)$. De berekeningen zijn continu gedaan (alle dagen van de ronde).

${ }^{4}$ Per varkensplaats in de afdeling; omgerekend naar jaarbasis met een leegstand van $3 \%$. 


\subsection{Modelvalidatie biggen}

In tabel 26 zijn de gemeten en berekende waarden voor de belangrijkste modelvariabelen opgenomen voor de verschillende behandelingen. De gemiddelden en s.d.'s en de P-waarde voor een significant verschil tussen berekende en gemeten waarden. Tevens is de RMSE opgenomen voor elke variabele. Diergewicht en voeropname worden zeer goed berekend met RMSE's van respectievelijk 0,19 en 0,20 $\mathrm{kg}$. De drinkwateropname wordt ook goed berekend, met vrij geringe verschillen tussen berekende en gemeten waarden. Door het grote aantal waarnemingen was het verschil echter wel significant. De RMSE voor drinkwateropname was $1,4 \mathrm{~kg}$.

\section{Tabel 26}

Gemiddeld gemeten en berekende diergewichten en cumulatieve voer- en wateropnames (op de meetmomenten) bij de biggen.

\begin{tabular}{|c|c|c|c|c|c|c|c|c|}
\hline Variabele & Behand. & n & Gemeten & s.d. ${ }^{1}$ & Berekend & s.d. ${ }^{1}$ & $\mathbf{P}^{2}$ & RMSE \\
\hline \multirow[t]{3}{*}{$(\mathrm{kg})^{3}$} & Verl. eiwit & 4 & 16.9 & 6.1 & 16.9 & 6.1 & & \\
\hline & Zuur & 4 & 16.7 & 6.0 & 16.7 & 6.0 & & \\
\hline & Combi & 4 & 16.5 & 6.3 & 16.6 & 6.1 & & \\
\hline \multirow[t]{3}{*}{$(\mathrm{kg})$} & Verl. eiwit & 4 & 11.8 & 8.5 & 11.8 & 8.5 & & \\
\hline & Zuur & 4 & 11.1 & 8.1 & 11.2 & 8.1 & & \\
\hline & Combi & 4 & 11.4 & 8.4 & 11.5 & 8.4 & & \\
\hline \multirow[t]{3}{*}{$(\mathrm{kg})$} & Zuur & 70 & 22.9 & 19.1 & 23.0 & 19.0 & & \\
\hline & Combi & 70 & 20.3 & 16.0 & 19.8 & 15.8 & & \\
\hline & Alle & 280 & 23.0 & 18.3 & 22.5 & 18.1 & $<0.001$ & 1.4 \\
\hline
\end{tabular}

${ }^{1}$ s.d. = standaard deviatie

$2 \mathrm{P}=$ kans dat gemeten en berekende waarden gelijk zijn aan elkaar

${ }^{3}$ Het begingewicht is niet meegenomen als meetpunt.

In tabel 27 worden de resultaten weergegeven voor de gemiddeld gemeten en berekende waarden voor de samenstelling van de mest. Het mestvolume kon niet voldoende nauwkeurig worden gemeten vanwege het feit dat de meeste mest in de rioleringspijp liep en de mestproductie werd bepaald door de mesthoogte in het mestkanaal te meten. Het mestvolume is daarom niet opgenomen in de tabel. Uit de tabel blijkt dat het ds-, as-, Ntotaal- en K-gehalte van de mest allen hoger worden berekend dan gemeten. Dit verschil was niet significant voor het ds-gehalte, maar wel voor as-, Ntotaal- en Kgehalte. Daarentegen werden de gehalten aan $P(P=0,06)$, Ca $(P=0,16)$ en vluchtige vetzuren $(P=0,001)$ lager berekend dan gemeten. Er was echter alleen een significante tendens voor het $P$ gehalte $(P<0,10)$. NH4-N in de bulkmest en in de bovenste laag van de mest waren niet verschillend tussen de metingen en de berekeningen. De $\mathrm{pH}$ van de bulk mest werd gemiddeld iets lager berekend dan gemeten, terwijl de $\mathrm{pH}$ van de bovenste laag van de mest iets hoger werd berekend dan gemeten (voor zowel de directe meting op $0,5 \mathrm{~cm}$ diepte als de indirecte meting in de filtermonsters). 
Tabel 27

Gemiddeld gemeten en berekende samenstelling van de mengmest (op de meetmomenten) bij de biggen.

\begin{tabular}{|c|c|c|c|c|c|c|c|c|}
\hline Variabele & Behand. & n & Gemeten & s.d. ${ }^{1}$ & Berekend & s.d. ${ }^{1}$ & $P^{2}$ & RMSE \\
\hline Ds-gehalte & Controle & 4 & 86.7 & 54.6 & 94.7 & 31.2 & & \\
\hline \multirow[t]{4}{*}{$(\mathrm{g} / \mathrm{kg})$} & Verl. eiwit & 4 & 63.2 & 35.7 & 99.2 & 18.3 & & \\
\hline & Zuur & 4 & 101.2 & 40.5 & 89.8 & 22.1 & & \\
\hline & Combi & 4 & 93.1 & 52.6 & 117.4 & 26.0 & & \\
\hline & Alle & 16 & 86.1 & 44.1 & 100.3 & 28.1 & 0.26 & 49.3 \\
\hline As-gehalte & Controle & 4 & 17.7 & 9.6 & 23.8 & 9.7 & & \\
\hline \multirow[t]{4}{*}{$(\mathrm{g} / \mathrm{kg})$} & Verl. eiwit & 4 & 15.7 & 8.1 & 24.3 & 3.8 & & \\
\hline & Zuur & 4 & 20.1 & 7.9 & 22.0 & 6.1 & & \\
\hline & Combi & 4 & 21.2 & 10.4 & 29.5 & 7.8 & & \\
\hline & Alle & 16 & 18.7 & 8.4 & 24.9 & 7.0 & 0.02 & 11.4 \\
\hline N-totaal & Controle & 4 & 6.07 & 3.48 & 9.17 & 3.99 & & \\
\hline \multirow[t]{4}{*}{$(\mathrm{g} / \mathrm{kg})$} & Verl. eiwit & 4 & 4.23 & 1.87 & 7.85 & 1.46 & & \\
\hline & Zuur & 4 & 6.67 & 2.55 & 8.93 & 2.22 & & \\
\hline & Combi & 4 & 5.82 & 2.87 & 10.2 & 2.99 & & \\
\hline & Alle & 16 & 5.70 & 2.63 & 9.04 & 2.67 & $<0.001$ & 4.30 \\
\hline $\mathrm{NH} 4-\mathrm{N}$ & Controle & 4 & 2.35 & 1.02 & 2.60 & 0.35 & & \\
\hline \multirow[t]{4}{*}{$(\mathrm{g} / \mathrm{kg})$} & Verl. eiwit & 4 & 1.79 & 0.62 & 1.74 & 0.23 & & \\
\hline & Zuur & 4 & 2.41 & 0.69 & 2.59 & 0.28 & & \\
\hline & Combi & 4 & 2.37 & 0.83 & 2.27 & 0.22 & & \\
\hline & Alle & 16 & 2.23 & 0.77 & 2.30 & 0.44 & 0.76 & 0.87 \\
\hline $\mathrm{NH} 4-\mathrm{N}$ & Controle & 4 & 1.62 & 0.82 & 1.66 & 0.21 & & \\
\hline bovenlaag & Verl. eiwit & 4 & 1.27 & 0.26 & 1.12 & 0.19 & & \\
\hline mengmest & Zuur & 4 & 1.91 & 0.93 & 1.67 & 0.28 & & \\
\hline \multirow[t]{2}{*}{$(\mathrm{g} / \mathrm{kg})$} & Combi & 4 & 1.65 & 0.62 & 1.50 & 0.20 & & \\
\hline & Alle & 16 & 1.61 & 0.67 & 1.49 & 0.30 & 0.47 & 0.63 \\
\hline K-gehalte & Controle & 4 & 2.71 & 1.22 & 3.44 & 1.17 & & \\
\hline \multirow[t]{4}{*}{$(\mathrm{g} / \mathrm{kg})$} & Verl. eiwit & 4 & 2.43 & 0.80 & 3.62 & 0.65 & & \\
\hline & Zuur & 4 & 3.14 & 1.21 & 3.34 & 0.95 & & \\
\hline & Combi & 4 & 3.31 & 1.39 & 4.47 & 1.16 & & \\
\hline & Alle & 16 & 2.90 & 1.11 & 3.72 & 1.01 & 0.04 & 1.61 \\
\hline P-gehalte & Controle & 4 & 1.41 & 0.85 & 1.05 & 0.34 & & \\
\hline \multirow[t]{4}{*}{$(\mathrm{g} / \mathrm{kg})$} & Verl. eiwit & 4 & 1.10 & 0.62 & 1.01 & 0.08 & & \\
\hline & Zuur & 4 & 1.56 & 0.60 & 0.94 & 0.12 & & \\
\hline & Combi & 4 & 1.53 & 0.80 & 1.24 & 0.19 & & \\
\hline & Alle & 16 & 1.40 & 0.68 & 1.06 & 0.22 & 0.06 & 0.74 \\
\hline Ca-gehalte & Controle & 4 & 1.88 & 1.04 & 1.40 & 0.42 & & \\
\hline \multirow[t]{4}{*}{$(\mathrm{g} / \mathrm{kg})$} & Verl. eiwit & 4 & 1.70 & 1.02 & 1.68 & 0.34 & & \\
\hline & Zuur & 4 & 1.88 & 0.48 & 1.18 & 0.27 & & \\
\hline & Combi & 4 & 1.98 & 0.96 & 1.82 & 0.49 & & \\
\hline & Alle & 16 & 1.86 & 0.82 & 1.52 & 0.43 & 0.16 & 0.97 \\
\hline $\mathrm{VVZ}^{3}$ & Controle & 4 & 7.82 & 3.43 & 4.74 & 1.35 & & \\
\hline \multirow[t]{4}{*}{$(\mathrm{g} / \mathrm{kg})$} & Verl. eiwit & 4 & 5.93 & 4.14 & 4.71 & 1.05 & & \\
\hline & Zuur & 4 & 8.82 & 2.96 & 4.90 & 1.03 & & \\
\hline & Combi & 4 & 8.65 & 2.17 & 5.09 & 1.11 & & \\
\hline & Alle & 16 & 7.80 & 3.14 & 4.86 & 1.03 & 0.001 & 4.12 \\
\hline $\mathrm{pH}$ & Controle & 4 & 7.06 & 0.30 & 7.04 & 0.07 & & \\
\hline \multirow[t]{4}{*}{ mest bulk } & Verl. eiwit & 4 & 6.91 & 0.18 & 6.89 & 0.09 & & \\
\hline & Zuur & 4 & 7.13 & 0.18 & 6.64 & 0.11 & & \\
\hline & Combi & 4 & 6.97 & 0.33 & 6.57 & 0.08 & & \\
\hline & Alle & 16 & 7.02 & 0.24 & 6.78 & 0.21 & 0.02 & 0.42 \\
\hline
\end{tabular}




\begin{tabular}{|c|c|c|c|c|c|c|c|c|}
\hline Variabele & Behand. & n & Gemeten & S.d. ${ }^{1}$ & Berekend & S.d. ${ }^{1}$ & $\mathbf{p}^{2}$ & RMSE \\
\hline $\mathrm{pH}$ mest & Controle & 4 & 7.76 & 0.25 & 8.02 & 0.02 & & \\
\hline bovenlaag & Verl. eiwit & 4 & 7.66 & 0.34 & 7.97 & 0.03 & & \\
\hline \multirow[t]{3}{*}{ (filters) } & Zuur & 4 & 7.96 & 0.12 & 7.98 & 0.04 & & \\
\hline & Combi & 4 & 7.75 & 0.25 & 7.86 & 0.03 & & \\
\hline & Alle & 16 & 7.78 & 0.25 & 7.94 & 0.07 & 0.05 & 0.32 \\
\hline $\mathrm{pH}$ mest & Controle & 4 & 7.60 & 0.49 & 8.02 & 0.02 & & \\
\hline bovenlaag & Verl. eiwit & 4 & 7.41 & 0.36 & 7.97 & 0.03 & & \\
\hline \multirow[t]{3}{*}{$(0,5 \mathrm{~cm})$} & Zuur & 4 & 7.85 & 0.34 & 7.98 & 0.04 & & \\
\hline & Combi & 4 & 7.82 & 0.36 & 7.86 & 0.03 & & \\
\hline & Alle & 16 & 7.67 & 0.40 & 7.94 & 0.07 & 0.03 & 0.50 \\
\hline
\end{tabular}

${ }^{1}$ s.d. = standaard deviatie

${ }^{2} \mathrm{P}=$ kans dat gemeten en berekende waarden gelijk zijn aan elkaar

${ }^{3} \mathrm{VVZ}=$ totaal gehalte aan vluchtige vetzuren

In tabel 28 worden de gemeten en berekende $\mathrm{N}$-totaal gehalten van de verse urine weergegeven. Deze blijken significant te verschillen $\left(\mathrm{P}<0,001\right.$; RMSE $=3,16 \mathrm{~g} / \mathrm{kg}$ ). Het NH4-N gehalte en de $\mathrm{pH}^{\prime} \mathrm{s}$ van de urineplassen zijn niet gemeten (vanwege de volledig roostervloer).

\section{Tabel 28}

Gemiddeld gemeten en berekende samenstelling van de urineplassen (op de meetmomenten) bij de biggen.

\begin{tabular}{|c|c|c|c|c|c|c|c|c|}
\hline Variabele & Behand. & $\mathrm{n}$ & Gemeten & S.d. 1 & Berekend & s.d. ${ }^{1}$ & $\mathbf{P}^{2}$ & RMSE \\
\hline Verse urine & Verl. eiwit & 4 & 6.20 & 3.41 & 2.89 & 0.59 & & \\
\hline \multirow[t]{2}{*}{$(\mathrm{g} / \mathrm{kg})$} & Zuur & 4 & 6.36 & 2.70 & 3.71 & 0.53 & & \\
\hline & Combi & 4 & 3.50 & 1.45 & 3.56 & 0.72 & & \\
\hline
\end{tabular}

${ }^{1}$ s.d. = standaard deviatie

${ }^{2} \mathrm{P}=$ kans dat gemeten en berekende waarden gelijk zijn aan elkaar

In tabel 29 worden de gemiddelde gemeten en berekende ammoniakemissies gegeven voor de verschillende behandelingen. De totale ammoniakemissie wordt iets lager ingeschat dan gemeten $(0,24$ vs. $0,30 \mathrm{~kg} / \mathrm{jaar})$. Dit verschil was significant $(P<0,001)$. De gemiddeld gemeten ammoniakemissies waren respectievelijk 0,34, 0,24,0,35 en 0,28 kg/jaar per biggenplaats. De systematische afwijking (bias) tussen berekende en gemeten waarden was $-0,02 \mathrm{~kg} / \mathrm{jaar}$ voor de controle-, $-0,03 \mathrm{~kg} / \mathrm{jaar}$ voor de eiwit-, $-0,11 \mathrm{~kg} / \mathrm{jaar}$ voor de zuur- en -0,10 kg/jaar voor de combibehandeling. De overall bias voor alle afdelingen samen was $-0,06 \mathrm{~kg} / \mathrm{jaar}$. De RMSE voor het verschil tussen berekende en gemeten waarden was $0,16 \mathrm{~kg} / \mathrm{jaar}$.

De bijdrage van de vloer aan de totale ammoniakemissie werd gemiddeld ruim lager ingeschat dan gemeten (0,05 vs. 0,16 kg/jaar; $\mathrm{P}<0,001 ; \mathrm{RMSE}=0,15 \mathrm{~kg} / \mathrm{jaar}$ ). De berekende totale emissie op de dag voordat de mestkelders werden geleegd was gemiddeld iets lager dan de gemeten emissie $(0,36$ vs. 0,39 kg/jaar; RMSE $=0,07 \mathrm{~kg} / \mathrm{jaar}$ ). 
Tabel 29

Gemiddeld gemeten en berekende ammoniakemissie bij de biggen (in $\mathrm{kg} / \mathrm{jaar}$ per aanwezig varken ${ }^{1}$ ).

\begin{tabular}{|c|c|c|c|c|c|c|c|c|}
\hline Variabele & Behand. & $n$ & Gemeten & s.d. ${ }^{2}$ & Berekend & S.d. ${ }^{1}$ & $\mathbf{P}^{3}$ & RMSE \\
\hline totaal & Verl. eiwit & 56 & 0.24 & 0.11 & 0.21 & 0.17 & & \\
\hline dagelijks & Zuur & 56 & 0.35 & 0.20 & 0.24 & 0.15 & & \\
\hline$(\mathrm{kg} / \mathrm{jaar}$ & Combi & 56 & 0.28 & 0.14 & 0.18 & 0.14 & & \\
\hline NH3-emissie & Controle & 4 & 0.20 & 0.12 & 0.07 & 0.04 & & \\
\hline vloer & Verl. eiwit & 4 & 0.14 & 0.08 & 0.04 & 0.03 & & \\
\hline $1 x / 2 w_{k n}^{4}$ & Zuur & 4 & 0.16 & 0.10 & 0.05 & 0.02 & & \\
\hline NH3-emissie & Controle & 4 & 0.46 & 0.11 & 0.48 & 0.12 & & \\
\hline totaal & Verl. eiwit & 4 & 0.31 & 0.04 & 0.31 & 0.05 & & \\
\hline \multirow[t]{3}{*}{$1 x / 2 w k n^{5}$} & Zuur & 4 & 0.43 & 0.16 & 0.38 & 0.13 & & \\
\hline & Combi & 4 & 0.39 & 0.09 & 0.29 & 0.07 & & \\
\hline & Alle & 16 & 0.39 & 0.11 & 0.36 & 0.12 & 0.10 & 0.07 \\
\hline
\end{tabular}

${ }^{1}$ Berekend per aanwezig varken, maar omgerekend naar jaarbasis met een leegstand van $9 \%$.

2 s.d. = standaard deviatie

${ }^{3} \mathrm{P}=$ kans dat gemeten en berekende waarden gelijk zijn aan elkaar (bij $\mathrm{P}<0.05$ significant verschil)

${ }^{4}$ Steeds gemeten nadat de mest is afgelaten en de mestkelder vol gezet is met water.

${ }^{5}$ Steeds gemeten een dag voor het aflaten van de mest

In figuren 16 en 17 wordt het verloop gegeven van de gemeten en berekende ammoniakemissies tijdens de groeiperiode van de biggen voor de verschillende behandelingen en voor de beide ronden. Uit deze figuren blijkt dat in algemene zin het verloop van de ammoniakemissie redelijk voorspeld wordt voor de verschillende behandelingen. Opvallend is wel dat in de eerste ronde de ammoniakemissie al op een vrij hoog niveau begint. Dit in tegenstelling tot de berekende waarden die ongeveer bij nul beginnen. In de tweede ronde start de gemeten ammoniakemissie beduidend lager en worden deze waarden veel beter voorspeld. Het lijkt er op dat de mestkelders in de eerste ronde niet volledig vrij waren van mest, waardoor de emissie al direct op een bepaald niveau startte. Verder zijn de emissiepiekjes in de $2^{\mathrm{e}}$ ronde bij behandeling 1 en 2 opvallend. Dit is waarschijnlijk een randeffect direct nadat de mestkelders zijn leeggemaakt. Opvallend is verder dat de ammoniakemissie bij de tweede keer aflaten van de mest en het vullen van het mestkanaal met water, veel minder wordt gereduceerd dan bij de eerste keer mest aflaten. Dit zou veroorzaakt kunnen zijn doordat de kunststof roosters richting het eind van de ronde de mest minder goed doorlaten, waardoor er meer urine op de roostervloer achterblijft die kan emitteren. 

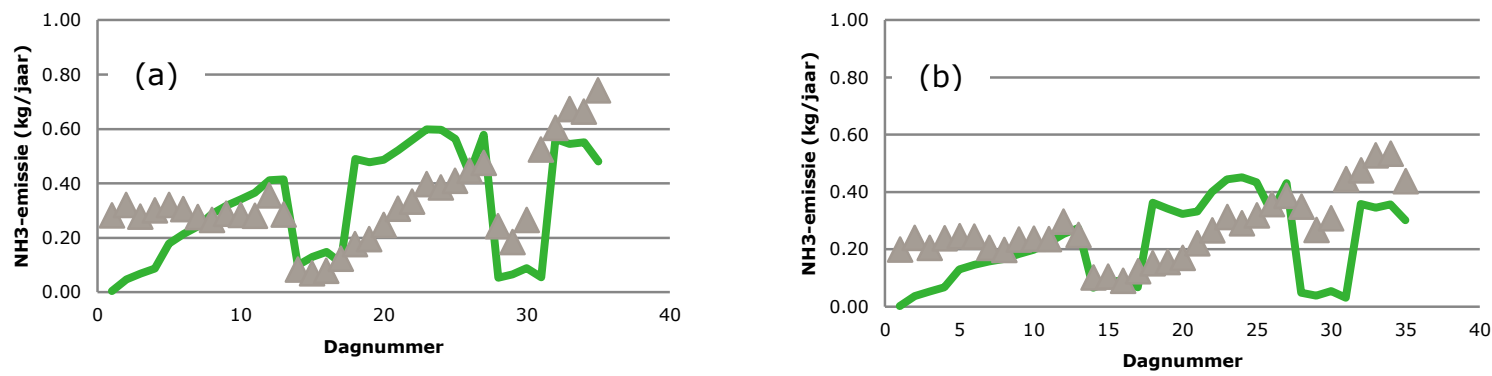

$\Delta$ gemeten $\longrightarrow$ berekend
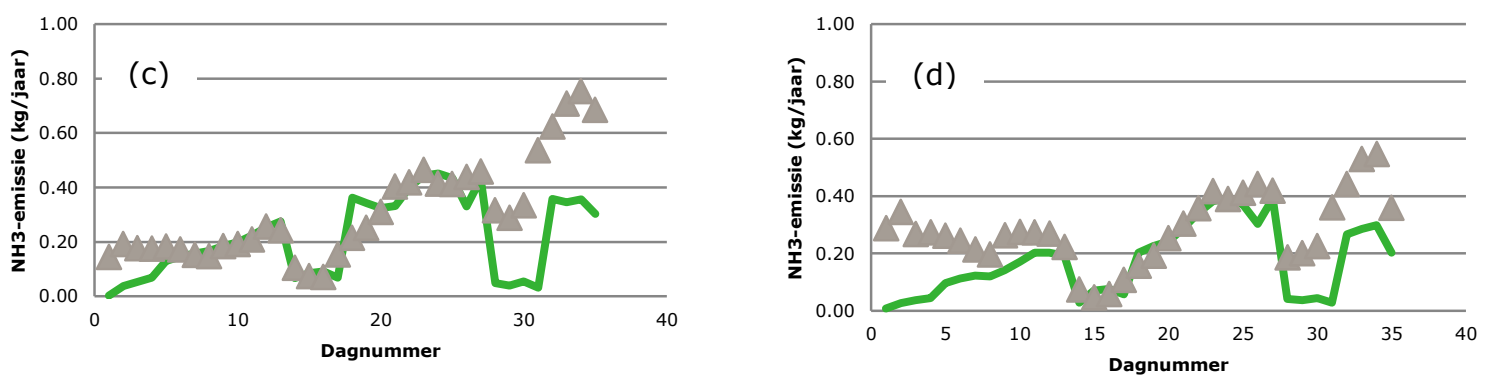

$\Delta$ gemeten $\longrightarrow$ berekend

$\triangle$ gemeten $\longrightarrow$ berekend

Figuur 16. Vergelijking tussen berekende $(Y)$ en gemeten $(X)$ waarden voor de ammoniakemissie (kg/jaar per dierplaats) voor de 4 voerbehandelingen in de eerste ronde: (a) controle; b) verlaagd eiwit; c) zuur; d) combi.

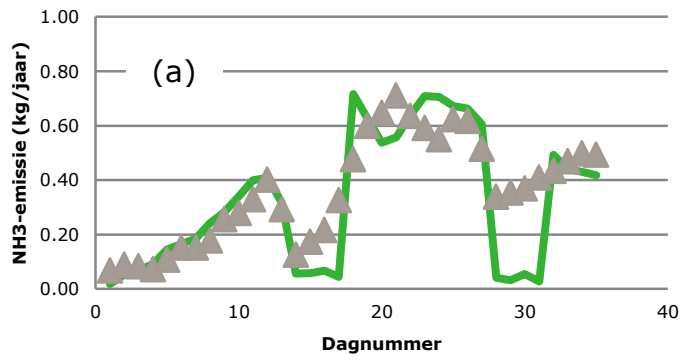

$\Delta$ gemeten $\longrightarrow$ berekend

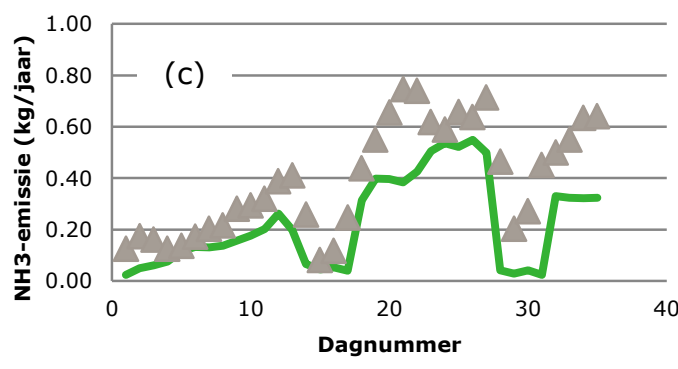

$\Delta$ gemeten berekend

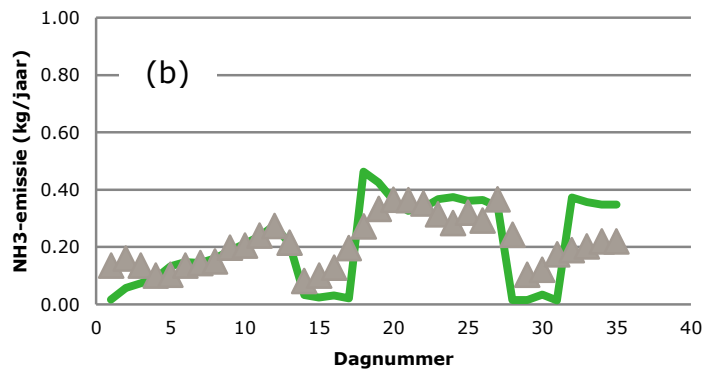

gemeten $\longrightarrow$ berekend

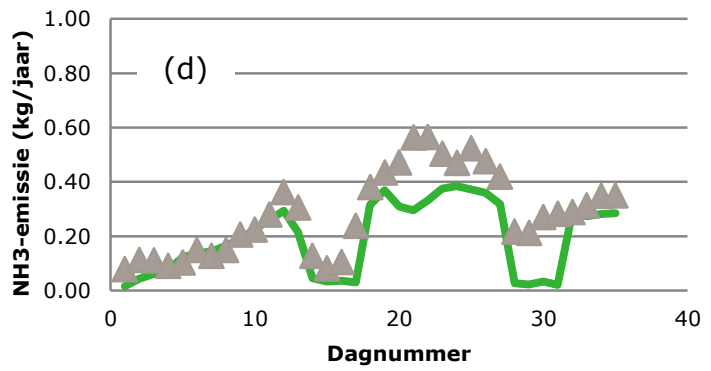

$\Delta$ gemeten berekend

Figuur 17. Vergelijking tussen berekende $(Y)$ en gemeten $(X)$ waarden voor de ammoniakemissie ( $\mathrm{kg} / \mathrm{jaar}$ per dierplaats) voor de 4 voerbehandelingen in de tweede ronde: (a) controle; b) verlaagd eiwit; c) zuur; d) combi. 


\subsection{Gemeten en berekende behandelingseffecten bij biggen}

In tabel 30 worden de gemeten en berekende effecten gegeven van de verschillende voerbehandelingen. Uit deze tabel blijkt dat de effecten van het eiwitgehalte van het voer zeer vergelijkbaar zijn voor de gemeten en berekende waarden. Dit geldt niet voor het effect van het zuur. Er wordt een duidelijk effect van het verzurende voer berekend, terwijl dit niet terug te zien is in de gemeten totale ammoniakemissie. Wel wordt dit effect gemeten voor de vloeremissie, waarbij zowel gemeten als berekend een reductie wordt gevonden van $12 \%$. Het berekende totale effect is nog groter (ca. 20\%), terwijl het effect van benzoëzuur op de emissie uit de mengmest nog niet is opgenomen in het model. De ammoniakemissies per $\mathrm{m}^{2}$ emitterende oppervlakken laten vergelijkbare effecten zien van de behandelingen.

\section{Tabel 30}

Gemeten en berekende effecten van de verschillende voerbehandelingen op de ammoniakemissie bij biggen. ( $n=24$ perioden; 3 perioden per afdeling $(4 x)$ en ronde (2x); na elke periode werd de mest afgelaten).

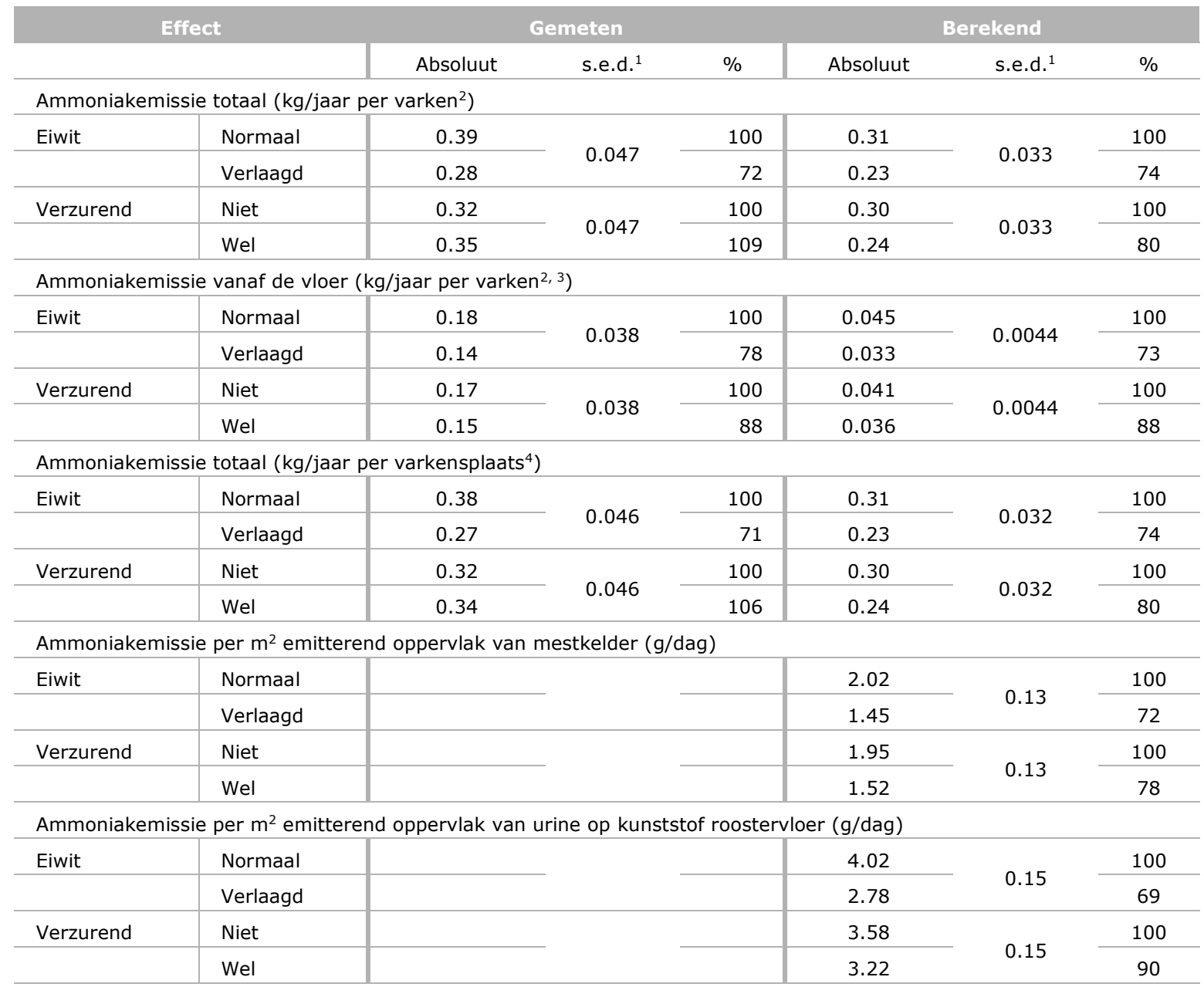

${ }^{1}$ s.e.d. = standaard error of difference

2 Per aanwezig varken in de afdeling; omgerekend naar jaarbasis met een leegstand van $9 \%$.

${ }^{3}$ De metingen zijn steeds gedaan na het mest aflaten, met water in de mestput $(n=24)$. De berekeningen zijn continu gedaan (alle dagen van de ronde).

${ }^{4}$ Per varkensplaats in de afdeling; omgerekend naar jaarbasis met een leegstand van $9 \%$.

${ }^{5}$ Omgerekend naar jaarbasis met een leegstand van $9 \%$. 


\subsection{Validatie model zeugen}

Bij de zeugen wordt de $\mathrm{pH}$ van de bulk mest te laag berekend wanneer dezelfde formule als voor vleesvarkens en gespeende biggen wordt gebruikt. Aangezien de $\mathrm{pH}$ van de bulk mest redelijk constant was en niet significant verschillend tussen de beide behandelingen, wordt voor de zeugen een vaste $\mathrm{pH}$ voor de bulk mest gehanteerd van: 7.48. Daarnaast werd een lagere $\mathrm{pH}$ van de bovenlaag van de mest berekend dan gemeten. Het lijkt er op dat deze pH te laag is ingeschat, daarom zijn we bij de simulaties uitgegaan van de gemiddeld gemeten $\mathrm{pH}$ in plaats van de berekende $\mathrm{pH}$ van de bovenste laag van de mest $(\mathrm{pH}=8,40)$. Voor de bulk $\mathrm{pH}$ van de urineplas hebben we het gemiddelde genomen van de directe $\mathrm{pH}$ meting $(\mathrm{pH}=8,57)$.

In tabel 31 worden de gemeten en berekende waarden gegeven voor diergewicht, voer- en drinkwateropname. De berekende waarden voor het eindgewicht van de zeugen zijn per definitie gelijk aan de gemeten waarden, aangezien het gewichtsverloop van de zeugen wordt berekend door lineaire interpolatie tussen begin- en eindgewicht. De voeropname is zeer vergelijkbaar tussen berekende en gemeten waarden. De drinkwateropname wijkt iets af voor het proefvoer, maar de fout is relatief gering.

\section{Tabel 31}

Gemiddeld gemeten en berekende diergewichten en cumulatieve voer- en wateropnames (op de meetmomenten) bij drachtige zeugen.

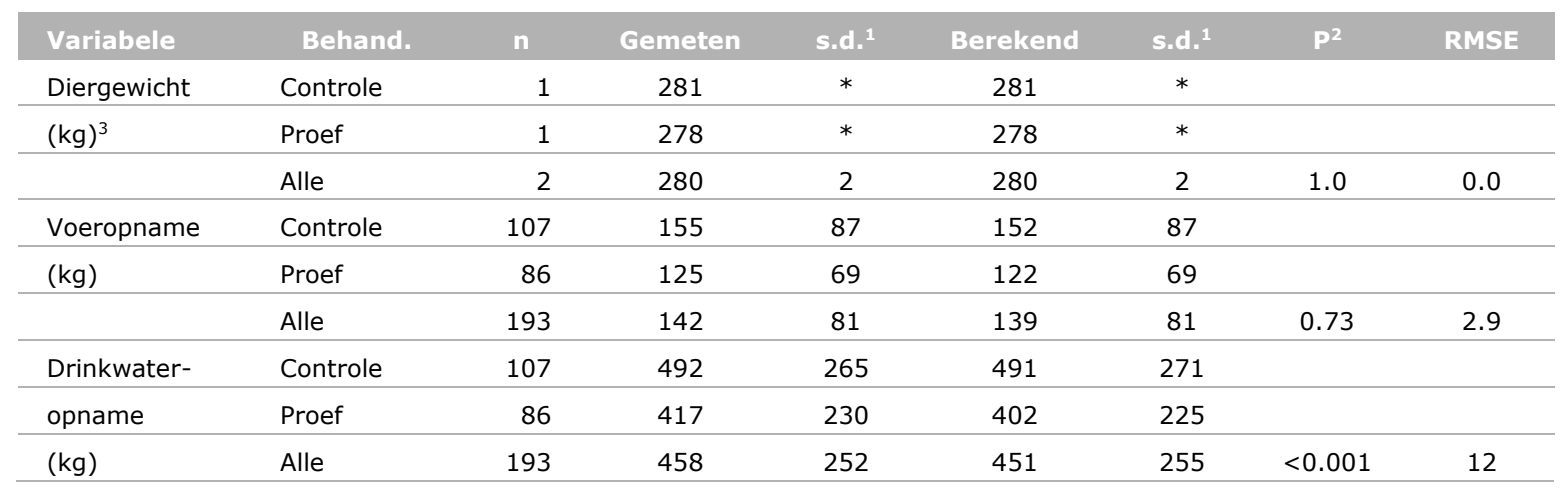

${ }^{1}$ s.d. = standaard deviatie

$2 \mathrm{P}=$ kans dat gemeten en berekende waarden gelijk zijn aan elkaar

${ }^{3}$ Zeugen zijn alleen bij de start en aan het eind gewogen. Dit zijn de eindgewichten, op het moment dat de zeugen uit de afdeling gingen.

In tabel 32 wordt de gemiddeld gemeten en berekende samenstelling van de mengmest voor het controle- en het proefvoer gegeven. Opvallend is dat het mestvolume flink hoger wordt berekend dan is gemeten; dit geldt vooral voor het controlevoer. Desondanks is het ds-gehalte van de mest voor het controlevoer hoger dan van het proefvoer. Dit lijkt vooral veroorzaakt te worden door lagere verteringscoëfficiënten van het voer (zie bijlage 5). Gemiddeld is er echter geen verschil in het dsgehalte van het voer tussen gemeten en berekende waarden. Dit geldt ook voor het as-gehalte en het $\mathrm{N}$-totaal gehalte. Er was een tendens dat het $\mathrm{NH} 4-\mathrm{N}$ gehalte van de bulk mest lager werd berekend dan gemeten. Dit verschil was significant voor de bovenste laag van de mest (ca. 15\% lager). Het berekende $\mathrm{K}$-gehalte was significant lager dan gemeten. Ook het P-gehalte was iets lager berekend dan gemeten; dit verschil was echter niet significant. Het Ca-gehalte was vergelijkbaar voor berekende en gemeten waarden. Het berekende gehalte aan vluchtige vetzuren was beduidend hoger dan gemeten. De berekende $\mathrm{pH}^{\prime}$ s van de bulk mest en van de bovenste laag van de mest waren gelijk gesteld aan de gemiddelde gemeten waarden, vandaar dat ze gemiddeld exact gelijk zijn. 
Tabel 32

Gemiddeld gemeten en berekende samenstelling van de mengmest (op de meetmomenten) bij drachtige zeugen.

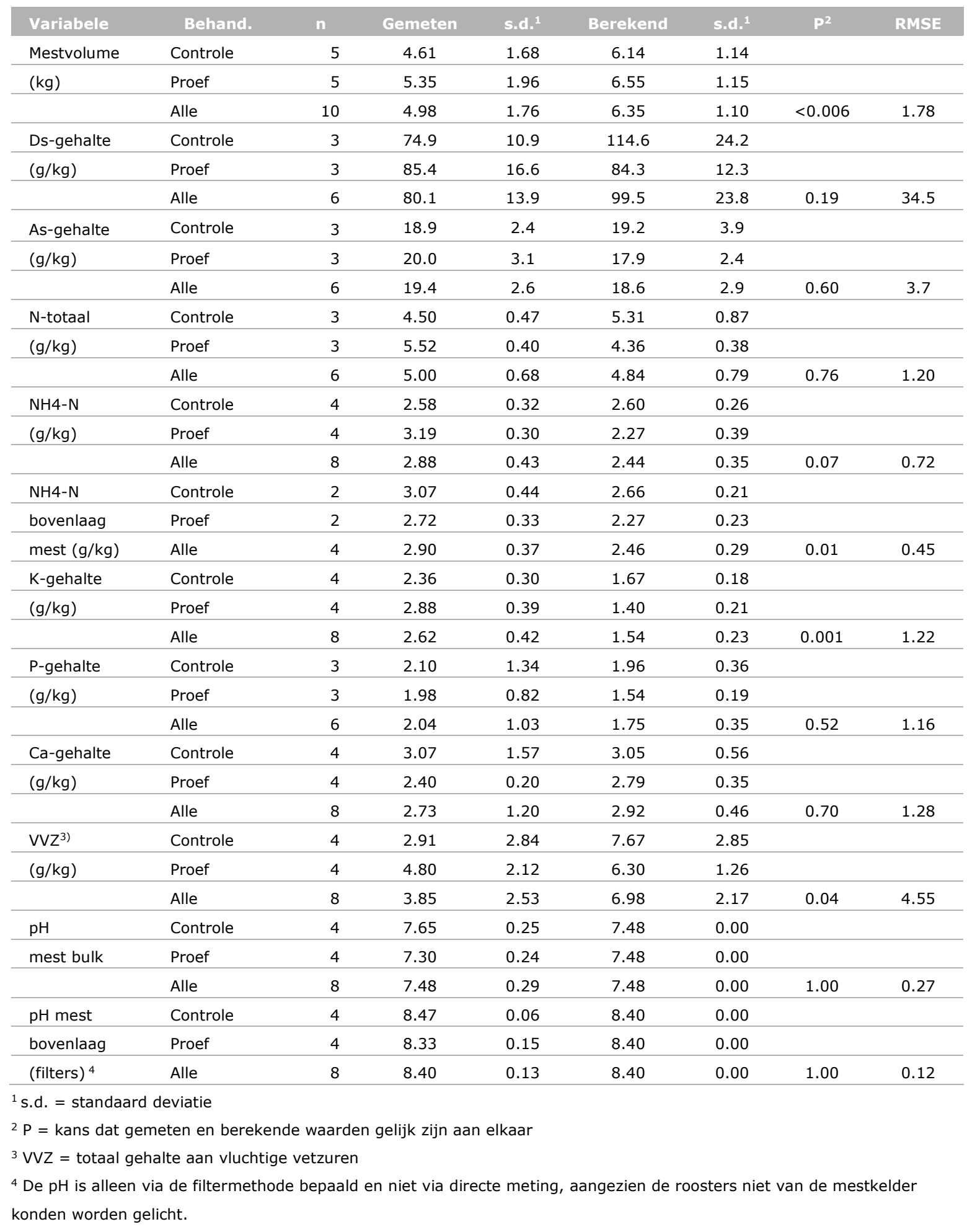

In tabel 33 worden de $\mathrm{N}$-gehalten en de $\mathrm{pH}^{\prime}$ s gegeven van urine(plassen). Bij de zeugen is het $\mathrm{N}$ totaal gehalte van de verse urine niet bepaald, daarom wordt in deze tabel het potentieel NH4-N gehalte gegeven. Uit deze tabel blijkt dat het potentiële $\mathrm{NH} 4-\mathrm{N}$ gehalte van verse urine en het $\mathrm{NH} 4-\mathrm{N}$ gehalte van urineplassen flink lager worden berekend dan gemeten. Voor de verse urine is dit bijna $40 \%$ lager en voor de urineplassen bijna 50\% lager. Dit heeft waarschijnlijk met inputgegevens van het model te maken. De verteringscoëfficiënten van het ruweiwit zijn waarschijnlijk niet goed ingeschat op basis van de grondstoffensamenstelling. Om verdere fouten richting de ammoniakemissie te voorkomen, zijn de berekende $\mathrm{NH} 4-\mathrm{N}$ gehalten van de urineplassen gecorrigeerd met een factor 2,00/1,03 (gem. gemeten/gem. berekend). 
Tabel 33

Gemiddeld gemeten en berekende samenstelling van de urineplassen (op de meetmomenten) bij drachtige zeugen.

\begin{tabular}{|c|c|c|c|c|c|c|c|c|}
\hline Variabele & Behand. & n & Gemeten & s.d. ${ }^{1}$ & Berekend & s.d. ${ }^{1}$ & $P^{2}$ & RMSE \\
\hline \multirow{2}{*}{$\begin{array}{l}\text { Pot. NH4-N } \\
\text { urine }{ }^{3} \\
(\mathrm{~g} / \mathrm{kg})\end{array}$} & Proef & 4 & 5.26 & 2.34 & 2.42 & 0.30 & & \\
\hline & Alle & 8 & 4.82 & 1.70 & 2.97 & 0.86 & 0.02 & 2.50 \\
\hline $\begin{array}{l}\mathrm{NH} 4-\mathrm{N} \\
\text { urineplas } \\
(\mathrm{g} / \mathrm{kg})^{4}\end{array}$ & Controle & 4 & 2.39 & 0.78 & 1.23 & 0.29 & & \\
\hline \multirow{3}{*}{$\begin{array}{l}\mathrm{pH} \\
\text { urineplas } \\
\text { direct (-) }\end{array}$} & Controle & 4 & 8.59 & 0.15 & 8.57 & 0.00 & & \\
\hline & Proef & 4 & 8.55 & 0.13 & 8.57 & 0.00 & & \\
\hline & Alle & 8 & 8.57 & 0.13 & 8.57 & 0.00 & 0.99 & 0.12 \\
\hline
\end{tabular}

${ }^{1}$ s.d. = standaard deviatie

$2 \mathrm{P}=$ kans dat gemeten en berekende waarden gelijk zijn aan elkaar

3 Potentieel NH4-N gehalte (totaal van ureum-N en $\mathrm{NH} 4-\mathrm{N}$ )

${ }^{4}$ Voor berekening van de $\mathrm{NH}_{3}$-emissie is de gemiddelde berekende waarde gecorrigeerd naar de gemiddelde gemeten waarde (factor $2,00 / 1,03$ )

In tabel 34 worden de gemeten en berekende ammoniakemissies gegeven. Hieruit blijkt dat de gemiddelde berekende ammoniakemissies goed overeenkomen met de gemiddeld gemeten emissies. De verschillen per behandeling (controle en proef) zijn echter vrij groot. De berekende emissie van de proefbehandeling is duidelijk lager dan de berekende emissie van de controle, dit verschil komt in de meting echter niet tot uiting en lijkt zelfs de andere kant op te werken.

\section{Tabel 34}

Gemiddeld gemeten en berekende ammoniakemissie (op de meetmomenten) bij drachtige zeugen.

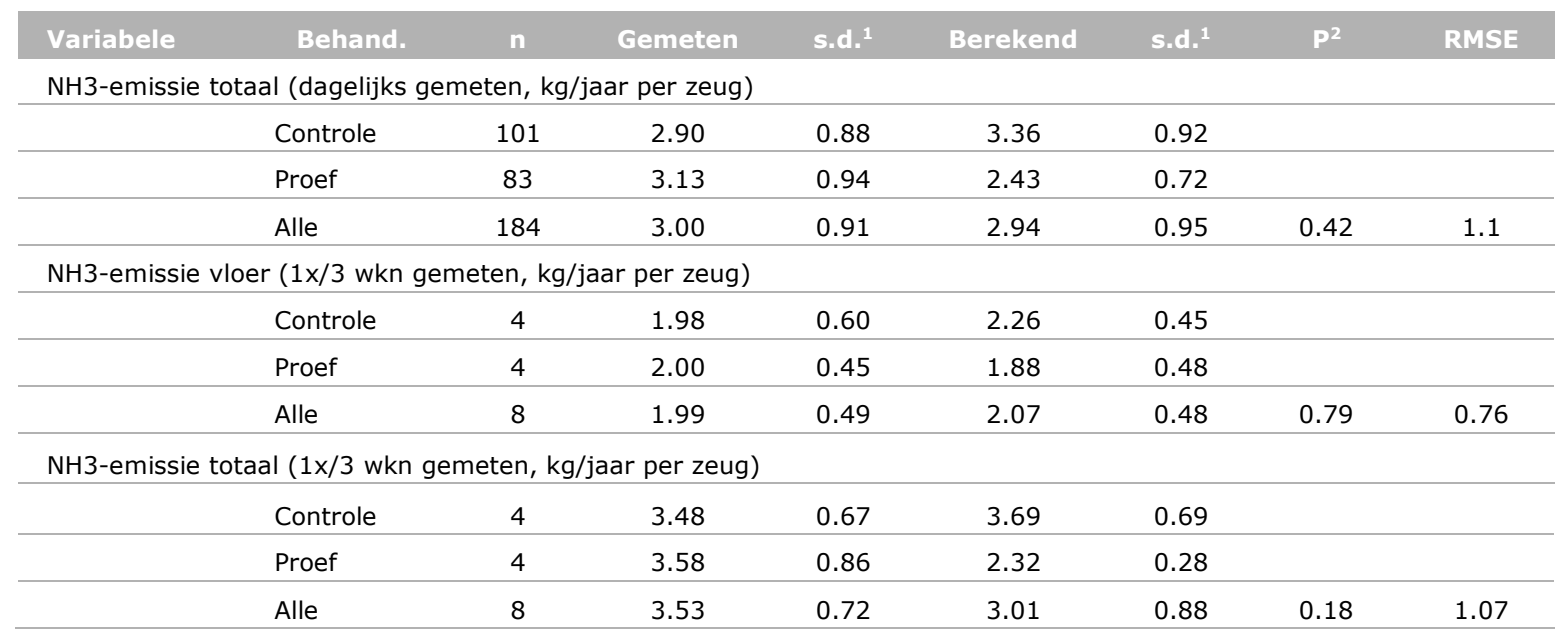

${ }^{1}$ s.d. = standaard deviatie

${ }^{2} \mathrm{P}=$ kans dat gemeten en berekende waarden gelijk zijn aan elkaar

In figuur 18 wordt het verloop gegeven van de ammoniakemissie voor de beide behandelingen in de zeugenafdelingen. Uit deze figuren blijkt dat het niveau van de ammoniakemissies redelijk wordt voorspeld, echter het patroon komt slechts hier en daar overeen met het gemeten patroon. 

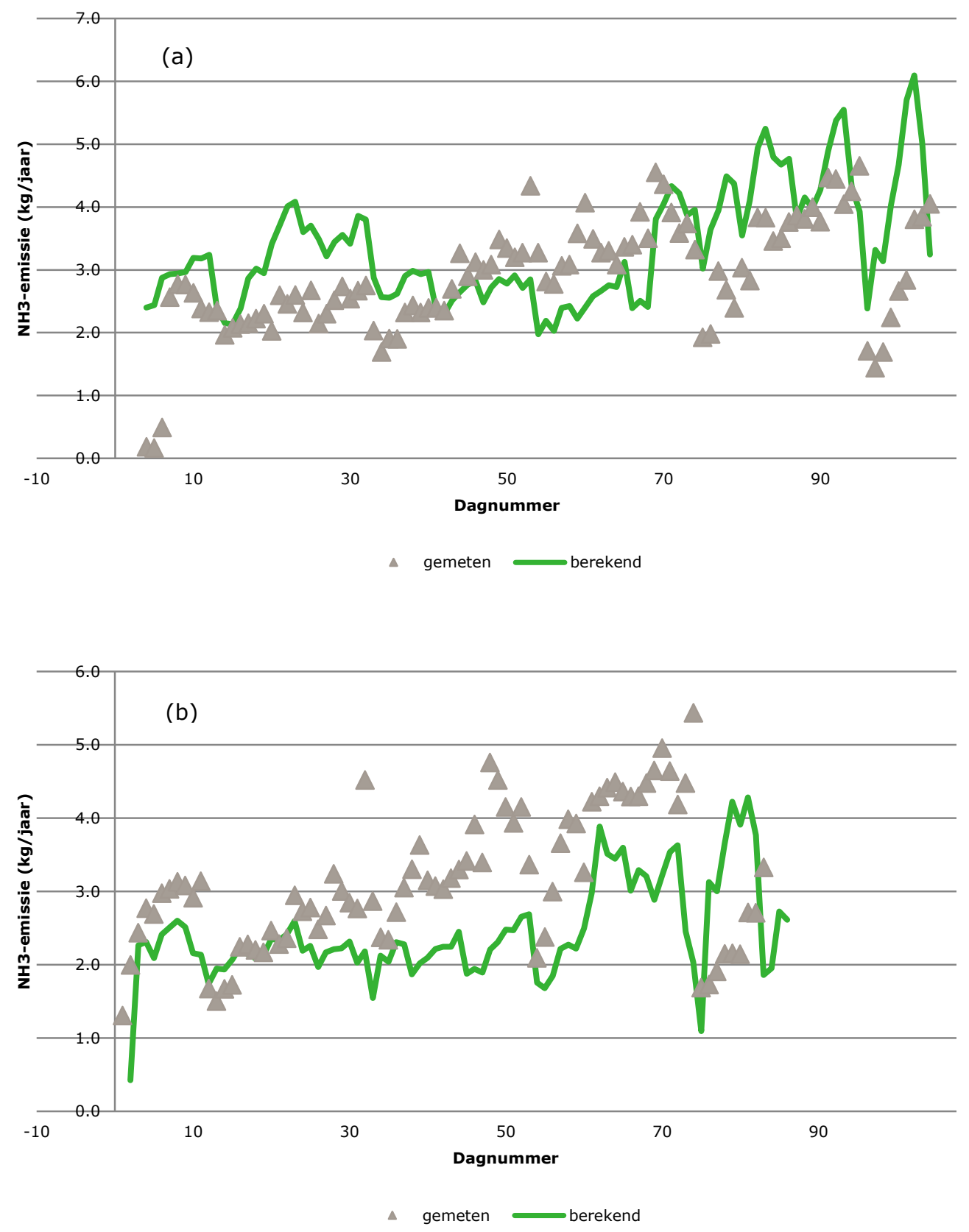

Figuur 18. Verloop van de ammoniakemissie( $\mathrm{kg} / \mathrm{jaar}$ per dierplaats) in de 2 zeugenafdelingen met de beide voerbehandelingen; (a) controle; b) proef (verlaagd eiwit en vervanging Ca-carbonaat door Caformiaat).

\subsection{Gemeten en berekende behandelingseffecten bij zeugen}

In tabel 35 worden de gemeten en berekende effecten gegeven van de beide voerbehandelingen bij de zeugen. Uit deze tabel blijkt dat berekende effecten van het proefvoer, met een verlaagd eiwit en vervanging van Ca-carbonat (krijt) door Ca-formiaat, niet overeenkomen met de gemeten effecten. Er wordt een reductie van ca. $30 \%$ berekend in ammoniakemissie, terwijl er geen effect uit de metingen blijkt. Het lijkt er op dat de inputgegevens van het model niet juist waren. Gezien het feit dat het ammoniumgehalte van de mest bij het proefvoer nog hoger was dan die van het controlevoer (zie vorige paragraaf) lijkt er op te wijzen dat de verteerbaarheden van het eiwit niet gelijk was voor beide voeders, terwijl dit wel werd berekend uit de veevoedertabel (zie bijlage 5). In de discussiehoofdstuk zal hier verder op in worden gegaan. Uit de tabel blijkt verder dat de berekende ammoniakemissie per $\mathrm{m}^{2}$ emitterend oppervlak beduidend hoger is voor de urineplassen op de 
betonnen vloer (dichte vloer + roostervloer) dan voor de mengmest in de mestkelder. De ammoniakemissie per $\mathrm{m}^{2}$ emitterend oppervlak van de schuine putwanden zat hier tussen in.

\section{Tabel 35}

Gemeten en berekende effecten van de verschillende voerbehandelingen op de ammoniakemissie bij zeugen. ( $n=10$ perioden; 5 perioden per afdeling; na elke periode werd de mest afgelaten).

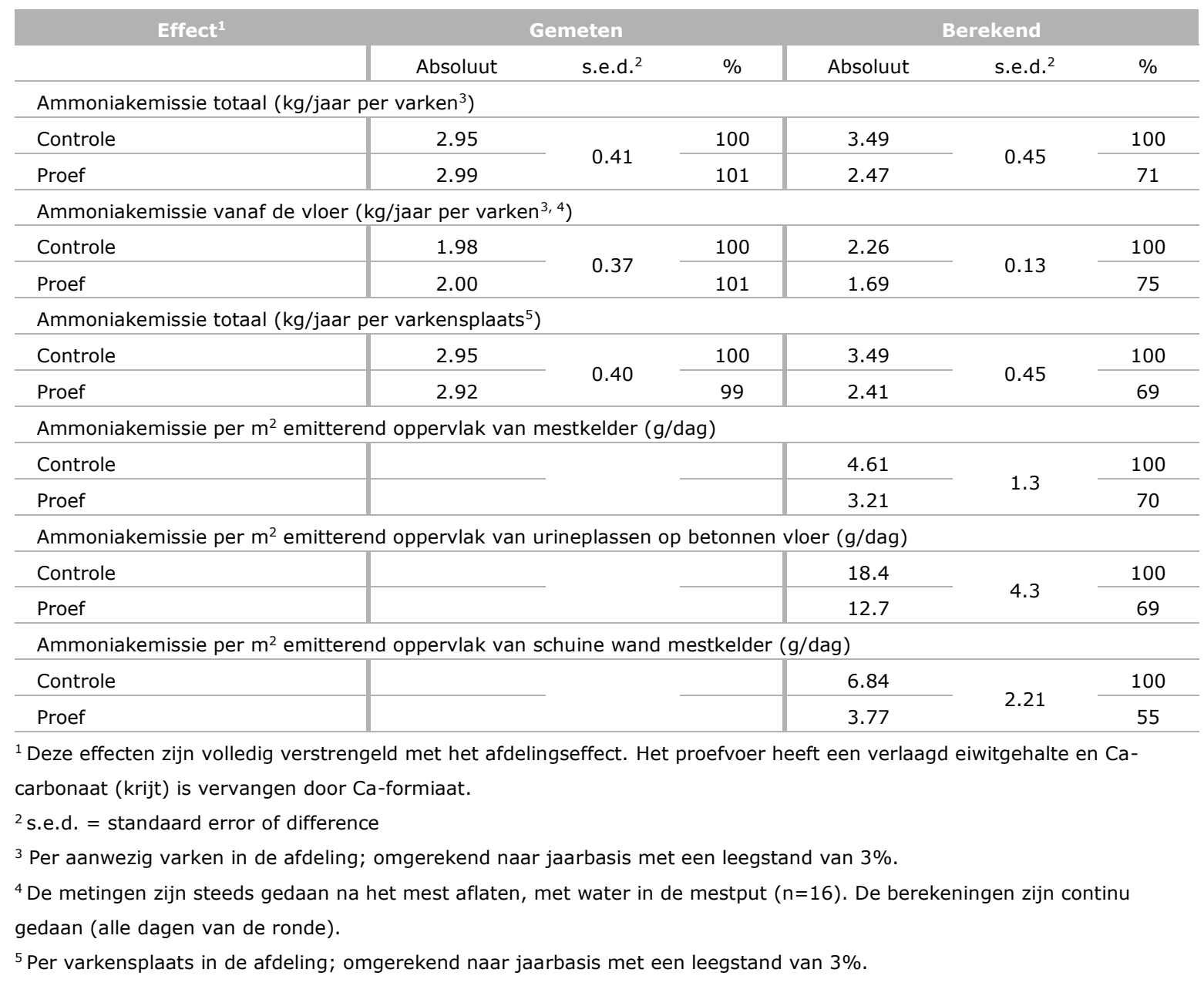

\subsection{Aanvullende analyse gemeten waarden}

In figuur 19a wordt de relatie weergegeven tussen de bulk $\mathrm{pH}$ van urineplassen (gemeten met de filtermethode) en de $\mathrm{pH}$ van de bovenlaag van de urineplas (gemeten via directe $\mathrm{pH}$ meting). In figuur $19 \mathrm{~b}$ wordt de relatie weergegeven tussen de bulk $\mathrm{pH}$ van de mengmest (gemeten direct na bemonstering van de mest) en de $\mathrm{pH}$ van de bovenlaag van de mengmest (gemeten met de filtermethode). In figuur 19c wordt een vergelijkbare figuur weergegeven, maar hierbij is de $\mathrm{pH}$ van de bovenlaag direct in de mestkelder gemeten op $0,5 \mathrm{~cm}$ diepte. In figuur $19 \mathrm{~d}$ is deze relatie weergegeven bij directe meting van de $\mathrm{pH}$ op $5 \mathrm{~cm}$ diepte. In deze figuren is tevens de regressielijn opgenomen die in het model zorgt voor omrekening van de bulk $\mathrm{pH}$ van urineplassen en mengmest naar de $\mathrm{pH}$ aan het oppervlak. Uit figuur 19a blijkt dat de regressielijn die in het model wordt gebruikt voor berekening van de $\mathrm{pH}$ van het oppervlak van urineplassen vrijwel gelijk is aan die berekend uit de metingen. Voor de mengmest (figuren 19a, b, c) geldt dit echter niet. De grote variatie van de gemeten bulk pH's worden aan het oppervlak genivelleerd met de regressielijn van het model. 

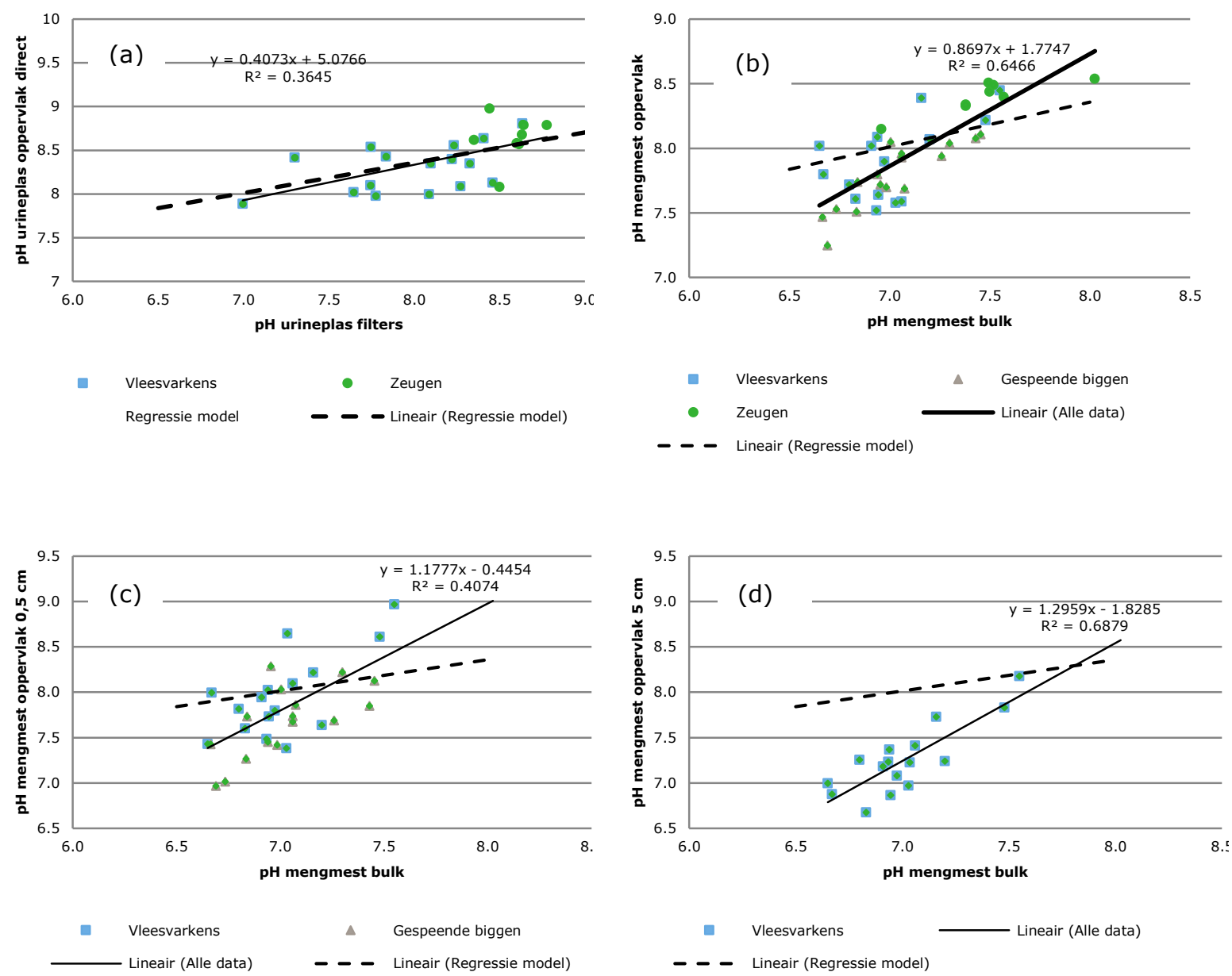

Figuur 19. Relaties tussen: a) $p H$ van urineplassen gemeten met filtermethode en directe $p H$ meting aan oppervlak urineplassen; b) $\mathrm{pH}$ van de bulk mengmest en $\mathrm{pH}$ aan het mestoppervlak gemeten met de filtermethode; c) $\mathrm{pH}$ van de bulk mengmest en $\mathrm{pH}$ aan het mestoppervlak gemeten op $0,5 \mathrm{~cm}$ via directe $\mathrm{pH}$ meting; d) $\mathrm{pH}$ van de bulk mengmest en $\mathrm{pH}$ aan het mestoppervlak gemeten op $5 \mathrm{~cm}$ via directe $\mathrm{pH}$ meting. In de figuren is tevens de regressielijn opgenomen die in het model zorgt voor omrekening van de bulk $\mathrm{pH}$ van urineplassen en mengmest naar de $\mathrm{pH}$ aan het oppervlak.

In figuur 20 wordt de relatie weergegeven tussen het potentieel NH4-N gehalte (alle ureum is omgezet) en werkelijk NH4-N gehalte (nog niet alle ureum is omgezet) in urineplassen (a) en in de bovenlaag van de mengmest (b). Hieruit blijkt dat in urineplassen vaak minder dan de helft van de ureum-N is omgezet in NH4-N. In de bovenlaag van de mengmest is dit bijna $80 \%$. 

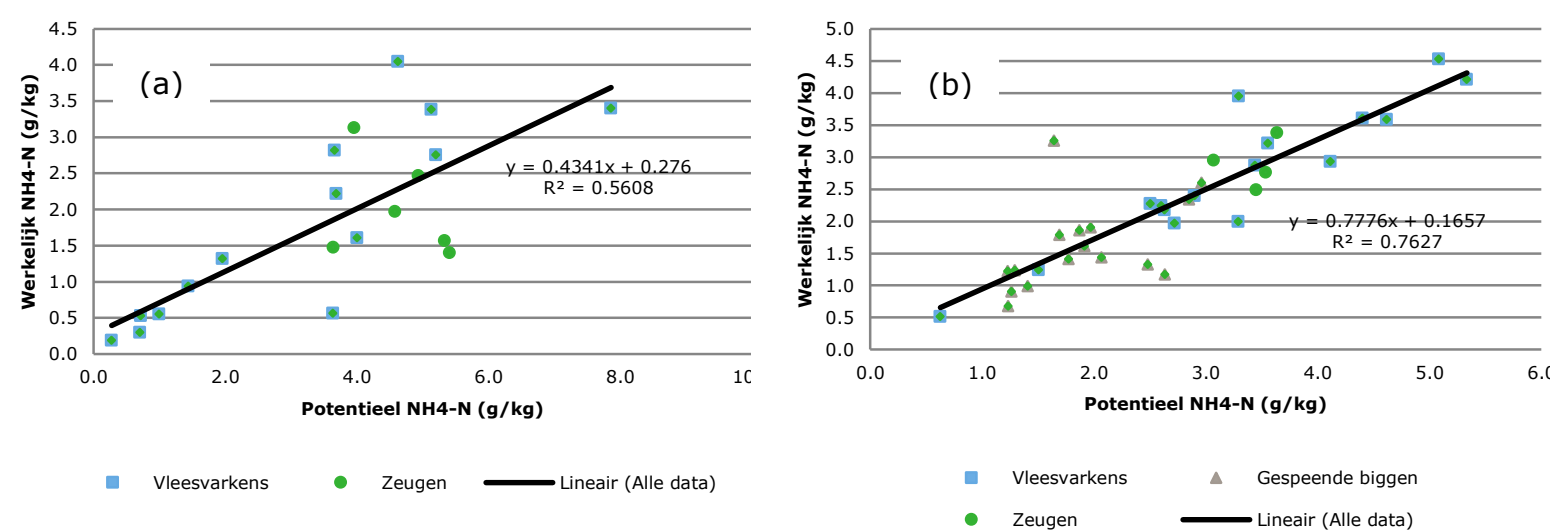

Figuur 20. Relaties tussen potentieel NH4-N gehalte (alle ureum is omgezet) en werkelijk NH4-N gehalte (nog niet alle ureum is omgezet): a) in urineplassen; b) in de bovenlaag van de mengmest.

In figuur 21 wordt het verloop van het aandeel vloeremissie gedurende de productieperiode weergegeven voor vleesvarkens, gespeende biggen en zeugen. Uit deze figuur blijkt dat een belangrijk deel van de ammoniakemissie van de vloer komt. Bij vleesvarkens en zeugen wordt de ammoniakemissie uit de mestkelder beperkt door de toepassing van schuine wanden en bij vleesvarkens met het waterkanaal. Echter ook bij gespeende biggen, waar geen ammoniakbeperkende maatregelen in de mestkelder zijn genomen, emitteert relatief veel ammoniak vanaf de vloer.

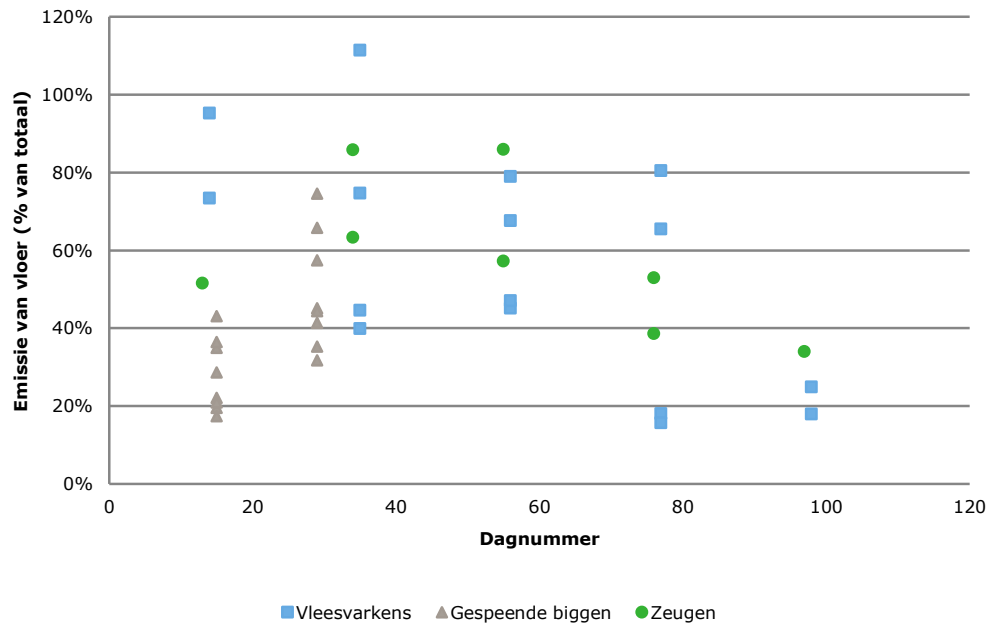

Figuur 21. Verloop van het aandeel vloeremissie gedurende de productieperiode voor vleesvarkens, gespeende biggen en zeugen. 


\section{$6 \quad$ Algemene discussie}

Het belangrijkste doel van dit onderzoek was het ontwikkelen van een rekentool waarmee de effecten van huisvestings- en voer- en managementmaatregelen op de ammoniakemissie bij vleesvarkens, gespeende biggen en zeugen kunnen worden berekend. Dit onderzoek is hier voor een (belangrijk) deel in geslaagd, maar op een aantal aspecten is verder onderzoek en verfijning nodig. In de hierna volgende paragrafen wordt ingegaan op een aantal variabelen in het model die een belangrijke invloed hebben op de berekening van de ammoniakemissie. Dit zijn achtereenvolgens: de inputgegevens, de eiwitaanzet, de waterverdamping, de bulk $\mathrm{pH}$ en de $\mathrm{pH}$ van de bovenlaag van urineplas en mengmest, de verschillende emitterende oppervlakken, de temperatuur en luchtsnelheid. Vervolgens zullen de analyses van de metingen worden bediscussieerd en de productieresultaten van de dieren in relatie tot de behandeling. Dit hoofdstuk sluit af met een algemene discussie van de mogelijkheden van het huidige model, waarvoor kan het worden ingezet en wat voor onderzoek is er nodig om het model verder te verbeteren.

\subsection{Inputgegevens}

De rekentool heeft een aantal inputgegevens. Deze zijn vermeld in paragraaf 2.1 en in paragraaf 5.1. In paragraaf 2.1 staan de inputgegevens vermeld die nodig zijn om effecten van voermaatregelen in te kunnen schatten met het model. De inputgegevens van paragraaf 5.1 waren nodig om het model te kunnen valideren. De inputgegevens benodigd voor het in kunnen schatten van effecten van voermaatregelen zijn dusdanig gekozen dat ze relatief eenvoudig te verkrijgen zijn. Belangrijk bij het bepalen van effecten van bepaalde maatregelen, dit geldt voor zowel voermaatregelen als voor huisvestings- en managementmaatregelen, is dat er een goede referentiesituatie is gedefinieerd. Onlangs is een rapport uitgekomen die de referentiesituatie beschrijft voor verschillende diercategorieën, waaronder de verschillende varkenscategorieën (Ellen e.a., 2017, in druk). Voornoemd rapport kan als uitgangspunt dienen voor het beschrijven van de referentiesituatie voor het model en van daaruit kunnen alternatieve scenario's worden doorgerekend. Belangrijk bij de berekening van alternatieve scenario's, waaronder dus voermaatregelen, is dat de consequenties van bepaalde maatregelen op alle input-gegevens bekend moeten zijn. Uit de validatie van de rekentool bij zeugen lijkt het er op dat in het proefvoer niet alleen het eiwitgehalte is aangepast, naast de vervanging van Ca-carbonaat door Ca-formiaat, maar tevens de verteerbaarheid van het eiwit van de grondstoffen. Een ander voorbeeld is dat een bepaalde aanpassing van het voer tevens de groei van de dieren beïnvloed of de voer- of wateropname. Dit soort effecten, op andere input-gegevens dan de specifieke maatregel zelf, is van groot belang om een goede schatting van een bepaalde (voer)maatregel te kunnen maken. Het is belangrijk om dit soort effecten, voor zover ze nog niet bekend zijn, via onderzoek vast te stellen.

In dit onderzoek is voor de modelvalidatie gebruik gemaakt van met behulp van de Veevoedertabel (Anonymus, 2016) berekende verteringscoëfficiënten van de verschillende componenten in het voer op basis van de grondstoffensamenstelling. In de Veevoedertabel zijn echter alleen hoofdgroepen van grondstoffen opgenomen en specifieke grondstoffen kunnen nog vrij sterk variëren qua precieze samenstelling en verteerbaarheid van de componenten. Voor bepaling van effecten van voeraanpassingen is het belangrijk om hier goed inzicht in te hebben. Hierbij is het vooral van belang om te weten welke effecten direct samenhangen met de ingestelde voermaatregel. Effecten die niet direct samenhangen mogen constant worden gehouden. Echter bij implementatie van een bepaalde voermaatregel in de praktijk is het wel belangrijk om goede randvoorwaarden aan te geven waaronder een bepaald effect mag worden verondersteld. Bij de validatie van de rekentool bij zeugen, bijvoorbeeld, is het duidelijk dat het ingestelde verlaagde eiwitgehalte in het proefvoer geen effect had op de ammoniakemissie, terwijl dit wel verwacht mocht worden. Echter, als in het eiwitarme voer de verteerbaarheid van het eiwit omhoog gaat, dan kan het overall resultaat zijn dat de ureumconcentratie in de urine niet verandert. Uiteindelijk is het deze concentratie die bepalend is voor het effect op de ammoniakemissie. 
Ten aanzien van voermaatregelen die de $\mathrm{pH}$ van urine en mengmest beïnvloeden ligt dit nog een stuk gecompliceerder. De $\mathrm{pH}$ wordt namelijk door een heel aantal variabelen beïnvloed, waarvan de belangrijkste zijn het ammonium-, carbonaat- en vluchtig vetzuurgehalte. Deze 3 componenten in de mest worden weer beïnvloed door een heel scala van andere variabelen. Om effecten van verzurende maatregelen goed te kunnen bepalen is het daarom noodzakelijk om te bepalen wat mogelijke andere effecten zijn van een bepaalde voermaatregel. Daarnaast is het van belang om bij praktijkimplementatie, zoals hiervoor al aangegeven, goed de randvoorwaarden te schetsen waaronder een bepaald effect van een maatregel mag worden verwacht. Het voordeel van een modelmatige benadering is dat heel goed inzicht wordt verkregen in factoren die het effect van bepaalde maatregelen teniet kunnen doen of juist kunnen versterken. In het voorbeeld van de $\mathrm{pH}$ van de mest is het bijvoorbeeld van belang om te weten wat de bufferende werking is van andere componenten in de mest, bijvoorbeeld het carbonaatgehalte van de mest. Bij een hoog carbonaatgehalte mag een ander effect van een $\mathrm{pH}$ reducerende maatregel worden verwacht (b.v. toevoeging benzoëzuur aan het voer) dan bij een laag carbonaatgehalte.

\subsection{Eiwitaanzet}

$\mathrm{Er}$ is in het verleden vrij veel onderzoek gedaan naar de lichaamssamenstelling van groeiende varkens, vooral bij vleesvarkens. Dit onderzoek dateert in het algemeen al van meer dan 20 jaar geleden. Intussen is de genetische vooruitgang doorgegaan met hogere dagelijkse groeicijfers met vergelijkbare of kleinere hoeveelheden voer. Een deel van deze verbetering in groeicijfers zou veroorzaakt kunnen worden door een andere groeisamenstelling, waarbij er relatief meer water wordt aangezet. Voor de categorieën dieren in dit onderzoek is er daarom een correctiefactor gehanteerd voor de berekening van de wateraanzet uit de eiwitaanzet. Bij biggen is daarboven op nog een correctiefactor gezet gerelateerd aan de leeftijd van de dieren. In figuur 22a wordt de relatie weergegeven tussen de verhouding water/eiwit aanzet en het diergewicht, zoals die gehanteerd wordt in de huidige rekentool. Deze wordt in deze figuur vergeleken met de relatie zoals weergegeven in de paper van De Lange et al. (De Lange et al., 2003). Uit deze figuur blijkt dat de aanpassing ten opzichte van de relatie van De Lange et al. (2003) voor vleesvarkens relatief gering is en daardoor aannemelijk te maken is uit de genetische ontwikkeling in de laatste 20 jaren. De sterke stijging in deze verhouding bij de gespeende biggen is echter wat moeilijker als genetische ontwikkeling te verdedigen. Deze sterke stijging had het model echter nodig om niet in een negatieve $\mathrm{N}$-balans terecht te komen. In figuur $22 \mathrm{~b}$ wordt aangegeven hoe hoog deze verhouding minimaal zou moeten zijn om een ureum-N uitscheiding via de urine te verkrijgen van minimaal $10 \%$ van het verteerbare ruweiwit. Uit deze figuur blijkt dat met de aangepaste formule alle behandelingen vrijwel voldoen aan deze minimale eis.
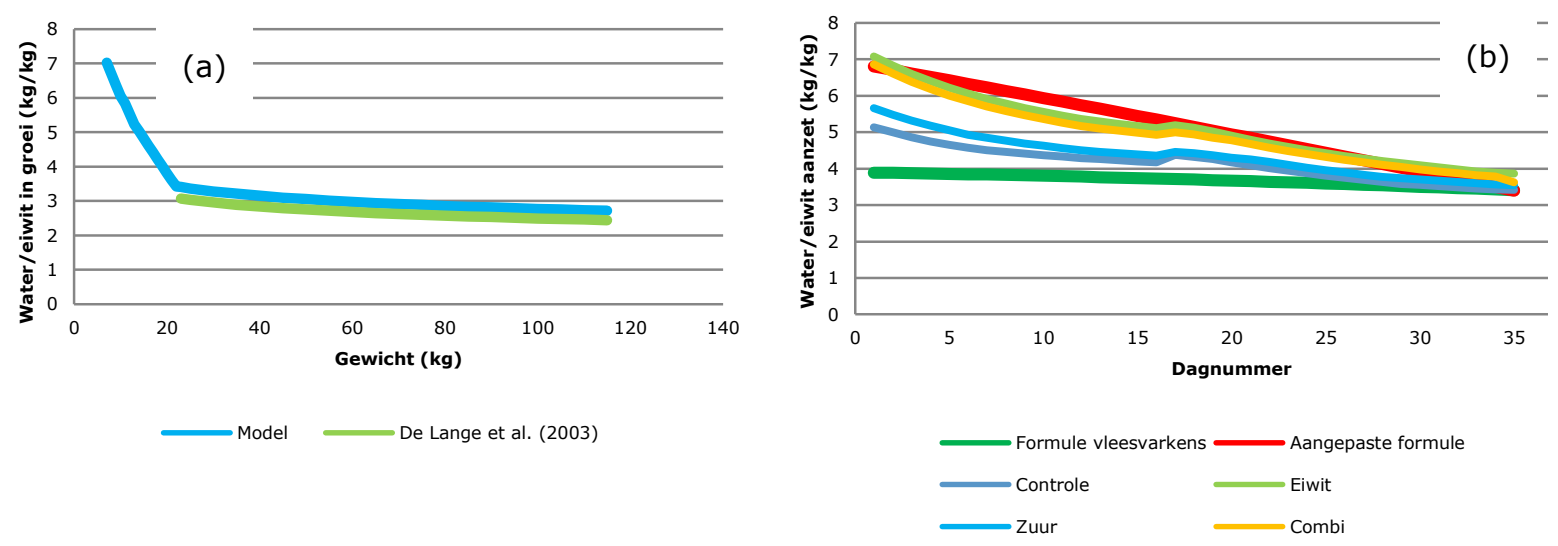

Figuur 22. a) De verhouding in aanzet tussen water en eiwit ( $B_{W / P}$ in het model) in afhankelijkheid van het diergewicht, zoals gehanteerd in de huidige rekentool en volgens de paper van De Lange et al. (2003). b) De verhouding die minimaal nodig is om een $\mathrm{N}$-excretie via de urine te verkrijgen van minimaal $10 \%$ van het verteerbare eiwit. 
Bij zeugen is heel weinig bekend over de aanzet van de verschillende componenten gedurende de drachtperiode. Zoals in paragraaf 2.7 al aangegeven zal de zeug na de zoogperiode vooral eiwit en vet aanzetten voor eigen groei, terwijl in de tweede helft van de dracht een steeds groter deel van de groei zal bestaan uit groei van de ongeboren biggen.

De maximale eiwitaanzet is input in het model. Echter wanneer deze wordt verhoogd, kan dit een negatieve $\mathrm{N}$-balans opleveren. Bij vleesvarkens en biggen wordt nog niet of nauwelijks tegen de grenzen van respectievelijk 170 en $140 \mathrm{~g} / \mathrm{d}$ aangelopen, bij zeugen is dit echter wel het geval bij een instelling van $100 \mathrm{~g} / \mathrm{d}$. Bij een verhoging van deze maximale eiwitaanzet zou de $\mathrm{N}$-concentratie in de urine nog verder dalen en deze was berekend al een heel stuk lager dan gemeten (zie par. 5.9).

\subsection{Waterverdamping}

De waterverdamping is een belangrijke variabele voor bepaling van de waterbalans in de stal. Van de totale hoeveelheid opgenomen voer en water is het aandeel in de totale massabalans van de verdamping gemiddeld $31 \%$ bij vleesvarkens, $45 \%$ bij biggen en $28 \%$ bij zeugen. Voor het nauwkeurig kunnen bepalen van het ammoniumgehalte in urine en mest is het daarom belangrijk dat deze variabele nauwkeurig kan worden berekend. De totale waterverdamping bestaat voor een deel uit de verdamping door het dier en voor een ander deel uit verdamping vanaf natte oppervlakken in de stal (vooral bevuilde vloeroppervlakken en het emitterend oppervlak in de mestkelder). Een belangrijke parameter in het model voor het berekenen van de waterverdamping vanaf natte oppervlakken in de stal is de verdampingscoëfficiënt. Deze is in het model lineair verondersteld met de wortel uit de luchtsnelheid en wordt berekend door deze te vermenigvuldigen met een regressiecoëfficiënt. Deze coëfficiënt is berekend op basis van de totale gemeten verdamping. Van deze totale verdamping is hiervoor eerst de verdamping door het dier afgetrokken. Een fout in de inschatting van de verdamping door het dier geeft dus een compenserende fout in de bepaling van de regressiecoëfficiënt. De geschatte regressiecoëfficiënten voor vleesvarkens, biggen en zeugen zijn behoorlijk vergelijkbaar met elkaar, namelijk respectievelijk 7.69, 6.22 en 7.00.

\section{4 $\mathrm{pH}$ van urine en mengmest}

Wellicht de belangrijkste variabelen voor het inschatten van de ammoniakemissie zijn de pH's van urine en mest. In eerste instantie is het de uitdaging om een goede schatting te maken van de $\mathrm{pH}$ van de bulk urine en mest en vervolgens is het de uitdaging om van daaruit een goede schatting te maken van de $\mathrm{pH}$ van de bovenste laag (de grenslaag met de lucht) van de urineplassen en de mengmest in de mestkelder. Op een lab van de Universiteit van Zuid Denemarken in Odense zijn relaties vastgesteld tussen verschillende componenten in de mengmest en de bulk pH en van daaruit met de $\mathrm{pH}$ van de grenslaag. De $\mathrm{pH}$ van de grenslaag is hierbij zeer nauwkeurig gemeten. In bijlage 2 worden de belangrijkste resultaten van dit onderzoek weergegeven. Voor ons model hebben we de meest simpele relaties gebruikt die op basis van dit onderzoek naar voren zijn gekomen. Door de relatief grote fout die wordt gemaakt in het schatten van de variabelen die de $\mathrm{pH}$ bepalen (ammonium-, carbonaat- en vluchtige vetzurengehalte) heeft het weinig zin om nauwkeuriger formules te gebruiken. Indien we deze variabelen in de mest echter meten, dan zouden we de nauwkeurige formules wel kunnen hanteren. In de mest is geen hippuurzuur bepaald. Hippuurzuur is het uitscheidingsproduct van benzoëzuur en deze component zorgt er voor dat de $\mathrm{pH}$ van urine en mengmest daalt als gevolg van de benzoëzuur toevoeging aan het voer. Het effect van benzoëzuur toevoeging aan het voer op de ammoniakemissie kon daarom met de huidige rekentool nog niet goed voorspeld worden. Het effect van benzoëzuur toevoeging aan het voer op de $\mathrm{pH}$ van de urine is wel onderdeel van het model.

Voor het goed kunnen schatten van de $\mathrm{pH}$ van de bulk urine en mest en van de grenslaag is het van belang dat de variabelen die de $\mathrm{pH}$ bepalen nauwkeurig bekend zijn. De huidige rekentool kan het ammoniumgehalte van de urine en mest redelijk voorspellen (wanneer de inputgegevens nauwkeurig bekend zijn). Het nauwkeurig voorspellen van het gehalte aan vluchtige vetzuren (alleen relevant voor mengmest en niet voor urine) is al een stuk moeilijker, aangezien deze samenhangt met de fermentatie in het dier zelf en met de fermentatie van de mest in de mestkelder. Helemaal moeilijk is het voorspellen van het carbonaat-gehalte van de urine en de mest. Deze kan waarschijnlijk alleen voorspeld worden door een directe koppeling te leggen met het voer, waarbij het dier zelf als een black box wordt gezien. De inschatting van de carbonaat-gehalten in urine en mest wordt extra 
bemoeilijkt door het feit dat het carbonaatgehalte van de urine en mest in evenwicht is met het carbonaatgehalte van de lucht. Hoeveel carbonaat er in de oplossing blijft is afhankelijk van de $\mathrm{pH}$. Dit betekent dat de $\mathrm{pH}$ en het carbonatgehalte elkaar wederzijds beïnvloeden. In de rekentool hebben we deze moeilijkheden omzeild door een directe relatie te leggen tussen het carbonaatgehalte van het voer en de $\mathrm{pH}$ van de mest. De regressielijn waarin de gemeten gehalten aan ammonium en vluchtige vetzuren waren opgenomen, samen met het Ca-carbonaat gehalte van het voer, kon $57 \%$ van de variatie in de bulk pH van de mengmest verklaren. De regressielijn waarin het gemeten TIC-gehalte (gehalte aan totaal anorganisch koolstof) was opgenomen, naast te gemeten gehalten aan ammonium en vluchtige vetzuren, kon $87 \%$ van de variatie in bulk $\mathrm{pH}$ van de mest verklaren.

Aangezien het op dit moment nog niet goed mogelijk is om een nauwkeurige schatting te maken van de $\mathrm{pH}$ van de bulk mengmest op basis van de huidige inputgegevens van de rekentool, is het alternatief om in een onderzoek de $\mathrm{pH}$ van de bulk mengmest te meten. Hierbij is het belangrijk dat er een representatief mestmonster wordt genomen. De $\mathrm{pH}$ van de grenslaag kan ook via meting worden vastgesteld of op basis van de $\mathrm{pH}$ van de bulk mest en het ammonium- en TIC-gehalte van de bulk mest (zie bijlage 2).

\subsection{Emitterende oppervlakken}

Een andere belangrijke variabele in de rekentool is het emitterend oppervlak. Zonder emitterende oppervlakken is er geen ammoniakemissie. In een varkensstal zijn er verschillende emitterende oppervlakken. In de vleesvarkensafdelingen konden de meeste verschillende emitterende oppervlakken worden onderscheiden in vergelijking met de biggen en de zeugen, namelijk: 1 ) emitterend oppervlak van het mestkanaal (achterste mestkelder in het hok); 2) emitterend oppervlak van het waterkanaal (voorste mestkelder in het hok); 3) emitterend oppervlak van de dichte betonnen vloer; 4) emitterend oppervlak van de betonnen roostervloer voor in het hok; 5) emitterend oppervlak van de metalen driekant roostervloer achterin het hok. Bij de biggen was er maar één emitterend kelderoppervlak en één emitterend vloeroppervlak (volledig kunststof rooster). Bij de zeugen was er naast een emitterend kelderoppervlak een emitterend betonnen dichte vloer en een emitterend betonnen roostervloer en een emitterende schuine wand in de mestkelder. De ammoniakemissie is lineair evenredig met de grootte van de emitterende oppervlakken.

In de rekentool zijn een aantal aannames gedaan ten aanzien van de emitterende oppervlakken:

1. De ammoniakemissie per $\mathrm{m}^{2}$ bevuild oppervlak is voor een betonnen roostervloer gelijk aan die van een dichte betonvloer.

2. Een metalen roostervloer emitteert $1 / 3$ deel van een betonnen roostervloer per $\mathrm{m}^{2}$ bevuild oppervlak.

3. Het ammoniumgehalte en de $\mathrm{pH}$ van met urine bevuilde schuine kelderwanden is gelijk aan die van urineplassen op de (rooster)vloer.

4. De temperatuur van en de luchtsnelheid over het emitterend oppervlak van de schuine wanden is gelijk aan die van de mest in de mestkelder.

De aanname onder punt 1 is op dit moment niet te staven met ander onderzoek. Er mag van uit worden gegaan dat de urease-activiteit niet beperkend is voor beide vloeren (Braam \& Swierstra, 1999). Tevens mag er vanuit worden gegaan dat de luchtsnelheid vergelijkbaar is over beide emitterende oppervlakken. De temperatuur zou voor de dichte vloer wat hoger kunnen zijn dan voor de roostervloer, vanwege het feit dat de dieren in het algemeen meer op de dichte vloer liggen dan op de roostervloer en vanwege het feit dat de dichte vloer is geïsoleerd. Voor het werkelijke emitterende oppervlak van de roostervloer zou eigenlijk gecorrigeerd moeten worden voor de spleten in het rooster. Daar staat echter tegen over dat er ook urine blijft hangen aan de zijkant en de onderkant van het rooster. Bij punt 2 zijn we er van uitgegaan dat het totale bevuilde oppervlak bij toepassing van metalen roosters vergelijkbaar is met toepassing van betonnen roosters. De doorlaat van metalen driekantroosters is in het algemeen beter dan van betonnen roosters, daarom zou het bevuilde oppervlak bij metalen roosters kleiner kunnen zijn. Uit onderzoek van Aarnink et al. (Aarnink \& Elzing, 1998; Aarnink et al., 1997) blijkt dat het reductie-effect van metalen driekantroosters vooral lijkt te worden veroorzaakt door een verlaagde urease-activiteit en niet zozeer doordat er minder urine blijft hangen aan de roostervloer. Het derde en het vierde punt zijn waarschijnlijk redelijke aannames. 
De bronsterkte (emissie per $\mathrm{m}^{2}$ oppervlak) van de emitterende oppervlakken is afhankelijk van het ammoniumgehalte en de $\mathrm{pH}$ van de emitterende vloeistof en van de temperatuur van en de luchtsnelheid over het emitterend oppervlak. Zoals blijkt uit de resultaten bij vleesvarkens en biggen is het ammoniumgehalte van de bovenlaag niet gelijk aan die van de bulk mest. Dit heeft aan de ene kant te maken met de diffusiesnelheid van ammonium relatief ten opzichte van de emissiesnelheid van ammoniak, en aan de andere kant met een nog onvolledige omzetting van ureum naar ammonium. Dit laatste kan vooral het geval zijn wanneer de urine als een laag bovenop de mest blijft staan en zich dus niet goed mengt met de rest van de mest. Vooral bij vleesvarkens en in wat mindere mate ook bij biggen is de bovenlaag van de mest vaak vrij dik, waardoor de urine wat minder goed mengt met de rest van de mest dan bij zeugen. Bij zeugen werd geen verschil in ammoniumgehalte van de bulk mest en de bovenste laag van de mest gevonden. De $\mathrm{pH}$ van de emitterende oppervlakken is in de vorige paragraaf al behandeld en de temperatuur en de luchtsnelheid worden in de volgende paragraaf behandeld.

De grootte van de verschillende emitterende oppervlakken is input in het model. De emitterende oppervlakte van mestkanalen met rechter wanden is gemakkelijk te berekenen. Voor mestkanalen met schuine wanden is dit afhankelijk van de mestproductie van de dieren. De emitterende oppervlakken van de (rooster)vloer en de schuine wanden is via waarneming vastgesteld. Het model zou op dit gebied nog verder ontwikkeld kunnen worden door een urine-lozingsmodel te ontwikkelen. Dit urine-lozingsmodel is in het verleden al ontwikkeld door Aarnink \& Elzing (1998) en zou gekoppeld kunnen worden aan het huidige model. Door deze koppeling ontstaat een dynamisch model waarmee ook de variatie in de ammoniakemissie gedurende de dag kan worden berekend. Het huidige model berekent alleen daggemiddelde ammoniakemissies.

\subsection{Temperatuur en luchtsnelheid}

De temperaturen van en de luchtsnelheden over de emitterende oppervlakken worden in de rekentool berekend uit respectievelijk de temperatuur van de uitgaande stallucht en de ventilatiehoeveelheid in $\mathrm{m}^{3} / \mathrm{s}$ per $\mathrm{m}^{2}$ staloppervlak. Deze laatste twee variabelen zijn in het algemeen vrij goed te meten. Uit de verschillende regressielijnen met gemeten waarden blijkt dat slechts een deel van de variatie met deze regressielijnen wordt verklaard. Op dit moment hebben we echter geen tools beschikbaar om de temperatuur en luchtsnelheid van de emitterende oppervlakken beter in te schatten. In het onderzoek wereldwijd wordt wel steeds meer gebruik gemaakt van luchtstromingsmodellen om de temperatuur en luchtsnelheid op verschillende plaatsen in een stal te schatten. Deze modellen zijn echter nog niet geschikt om snel en op een relatief eenvoudige manier voor verschillende stalconfiguraties en verschillende varkenscategorieën schattingen te maken van de temperatuur en de luchtsnelheid boven de verschillende emitterende oppervlakken. Extra inspanningen de komende jaren kan hier echter verandering in brengen.

\subsection{Analyse van metingen en behandelingseffecten}

Uit verschillende figuren waarin gemeten en berekende waarden zijn weergegeven (zie bijvoorbeeld par. 5.3) blijkt dat gemeten waarden een veel grotere variatie vertonen dan berekende waarden. Dit geldt bijvoorbeeld voor het ammoniumgehalte en de $\mathrm{pH}$ van de mest. Dit zal enerzijds worden veroorzaakt doordat de werkelijke variatie nog niet goed door de rekentool kan worden gesimuleerd, anderzijds zal het ook worden veroorzaakt door variaties die worden veroorzaakt door het moment van meten (zijn dieren bijvoorbeeld net actief of niet) of door niet voldoende representatief te bemonsteren. De uiteindelijke variaties die optreden in de ammoniakemissie blijken ondanks deze verschillen heel redelijk voorspeld te kunnen worden.

De metingen die niet continu zijn gedaan, dit zijn vrijwel alle metingen behalve de ammoniakemissie en de temperaturen en het ventilatiedebiet, zijn allemaal overdag gedaan. Een deel van deze metingen is gebruikt voor het ontwikkelen van regressielijnen, bijvoorbeeld om de oppervlaktetemperatuur en de luchtsnelheid van emitterende oppervlakken te bepalen. Een ander deel van de metingen is gebruikt als input voor het model. Dit geldt bijvoorbeeld voor het bevuilde 
vloeroppervlak. Al deze gegevens zijn vervolgens gebruikt om met de rekentool emissies per dag in te schatten. Om inzicht te krijgen in de variatie in ammoniakemissie tussen verschillende perioden van de dag is de dag ingedeeld in 3 perioden: 1) 08:30 - 16:30;2) 16:30 - 0:30;3) 0:30 - 8:30. Alle metingen zijn gedaan in de $1^{\mathrm{e}}$ periode. Bij vleesvarkens is geanalyseerd hoe groot de verschillen zijn in ammoniakemissie tussen deze perioden. Hieruit blijkt dat de gemiddelde ammoniakemissie in

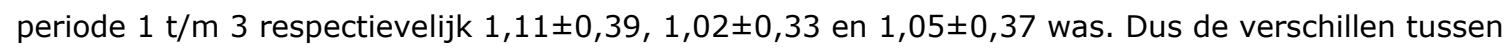
deze perioden zijn relatief klein. Daarom is de fout door de discontinue metingen allemaal overdag te doen waarschijnlijk relatief gering. Daarnaast zijn we vooral geïnteresseerd in relatieve verschillen en niet zozeer in absolute emissies. Relatieve verschillen worden naar verwachting nog minder beïnvloed door het moment van meten dan absolute verschillen.

De gemeten effecten van de voerbehandelingen zijn volgens verwachting. Uit de voeranalyses blijkt dat het eiwitgehalte in de behandeling met het verlaagde eiwit bij vleesvarkens gemiddeld met 18,1 $\mathrm{g} / \mathrm{kg}$ werd verlaagd, bij biggen met $21,8 \mathrm{~g} / \mathrm{kg}$ en bij zeugen met $11 \mathrm{~g} / \mathrm{kg}$. Bij vleesvarkens werd een gemiddeld gemeten effect gevonden van een verlaagd eiwitgehalte van het voer van $27 \%$. Dit is omgerekend een reductie van $15 \%$ ammoniakemissie per $10 \mathrm{~g} / \mathrm{kg}$ daling van het eiwitgehalte. Dit effect is wat groter dan is gevonden in eerder onderzoek (10 - 12,5\% per $10 \mathrm{~g} / \mathrm{kg}$ verlaging van het eiwitgehalte; (Aarnink \& Verstegen, 2007)). Bij biggen werd een reductie gemeten van 28\%. Dit komt overeen met een reductie van $12,8 \%$ per $10 \mathrm{~g} / \mathrm{kg}$ verlaging van het eiwitgehalte van het voer. Bij de zeugen werd geen effect van eiwitverlaging op de ammoniakemissie gevonden, vanwege al eerder genoemde redenen. De gemeten reductie van de ammoniakemissie door toevoeging van benzoëzuur $(1 \%)$ in combinatie met vervanging van Ca-carbonaat door Ca-formiaat was bij vleesvarkens gemiddeld $14 \%$. In eerder onderzoek werd voor toevoeging van alleen benzoëzuur ( $1 \%$ ) een effect gevonden van 15,8\% reductie (Aarnink et al., 2008). Het lijkt er daarom op dat de vervanging van Ca-carbonaat door Ca-formiaat niet veel effect heeft op de ammoniakemissie. Bij biggen werd bij toevoeging van benzoëzuur $(0,5 \%)$ en vervanging Ca-carbonaat door Ca-formiaat zelfs helemaal geen effect gemeten op de ammoniakemissie. Bij zeugen werd geen benzoëzuur toegevoegd aan het voer, maar werd alleen Ca-carbonat vervangen door Ca-formiaat. Ook hier lijkt er geen effect op te treden van deze vervanging. Het voorgaande geeft aan dat het moeilijk is te voorspellen hoe de $\mathrm{pH}$ van de urine en mest reageert op een veranderende voersamenstelling. Verder onderzoek hiernaar is nodig om dit soort maatregelen in te voeren. Beïnvloeding van de elektrolyten balans en daarmee van de $\mathrm{pH}$ van urine en mest kan compenserende reacties oproepen bij het dier, o.a. via botontkalking. Dit lijkt bij biggen het geval te zijn geweest, gezien het grote aantal behandelingen voor beenwerkaandoeningen in de behandeling met het verzurende voer.

\subsection{Productieresultaten}

Uit de resultaten blijkt dat vleesvarkens die gevoerd werden met het verlaagde eiwitvoer significant harder groeiden dan de vleesvarkens die controlevoer kregen verstrekt ( $922 \mathrm{vs} .876 \mathrm{~g} / \mathrm{d}$ ). De beide andere voeders zaten hier tussen in $(898 \mathrm{~g} / \mathrm{d}$ voor het verzurend voer en $894 \mathrm{~g} / \mathrm{d}$ voor het combivoer). De voederconversie was niet verschillend tussen de behandelingen. Het verschil in groei werd daarom volledig veroorzaakt door een verschil in voeropname. Wat de oorzaak is van deze verschillen is moeilijk aan te geven. Wel blijkt uit de resultaten dat dit verschil vooral in de start- en tussenvoerfase werd gerealiseerd. In de eindvoerfase was de groei van de verlaagde eiwitgroep zelfs duidelijk lager dan van de controlegroep. Het geslacht gewicht was ook hoger in de eiwitgroep en de combi-groep dan in de controlegroep. De spierdikte was echter significant hoger in de controlegroep ten opzichte van eiwit- en zuurgroep. De hoogste spierdikte werd echter gemeten in de combi-groep. De betere productieresultaten van de eiwitgroep zou gedeeltelijk verklaard kunnen worden door het feit dat het aantal gevallen van pleuritis en longafwijkingen in deze groep beduidend lager was dan in de andere groepen. Veruit de meeste longafwijkingen werden gevonden in de zuur-groep.

Bij de biggen groeiden de dieren in de combi-groep gedurende de eerste 16 dagen significant langzamer dan de dieren in de andere groepen. Over de gehele periode was er geen significant verschil tussen de behandelingen; de biggen in de zuur- en de combigroep groeiden echter gemiddeld minder snel dan de andere twee groepen. Dit kan verklaard worden door de iets lagere voeropname in de zuur- en combigroep. Opvallend is het relatief grote aantal biggen dat is uitgevallen in de 
zuurgroep $(P<0,10)$ en het grote aantal dieren dat behandeld moest worden in deze groep, vooral voor beenwerkaandoeningen $(P<0,001)$. Al deze zaken zouden er op kunnen wijzen dat het verzurend effect van het voer te groot was. Het is bekend dat het verstrekken van verzurend voer kan leiden tot botontkalking en minder sterk beenwerk (Smits et al., 2012).

Opvallend bij de zeugen is dat de dieren in de proefgroep, met een verlaagd eiwitgehalte en vervanging van $\mathrm{Ca}$-carbonaat door Ca-formiaat, een grotere gewichtstoename hadden tijdens de dracht bij een lagere gemiddelde voeropname dan de controlegroep. De oorzaak hiervan is moeilijk aan te geven. Wel waren er in de controlegroep meer zeugen die behandeld moesten worden voor kreupelheid.

\subsection{Betrouwbaarheid rekentool}

In het algemeen kan worden geconcludeerd dat de rekentool de urine- en mestsamenstelling redelijk kan voorspellen. De rekentool heeft van daaruit en met behulp van relaties die de temperatuur en de luchtsnelheid over het emitterend oppervlak voorspellen de ammoniakemissies per $\mathrm{m}^{2}$ emitterend oppervlak berekend. Door deze vervolgens te vermenigvuldigen met de grootte van de emitterende oppervlakken kon de ammoniakemissie op afdelingsniveau worden berekend. Deze berekende emissie is vervolgens vergeleken met de gemeten emissie op afdelingsniveau. Door regelmatig de mest in de mestkelder af te laten en deze te vullen met water kon ook de vloeremissie worden bepaald en deze kon ook worden vergeleken met de berekende vloeremissie.

Bij vleesvarkens kon de rekentool de absolute emissieniveaus redelijk goed voorspellen, zowel de totale emissie als de emissie vanaf de vloer. Ook kon de rekentool het effect van eiwitgehalte op de totale emissie uit de afdeling en de emissie vanaf de vloer goed voorspellen. Het effect van het verzurend voer kon echter niet goed worden voorspeld. Het effect van toevoeging van benzoëzuur is nog niet opgenomen in het model. Het gemeten effect van toevoeging van benzoëzuur ligt in de range van wat eerder gemeten is onder praktijkomstandigheden. In het huidige onderzoek werd een reductie vastgesteld van 14\%, terwijl dit in eerder onderzoek gemiddeld 15,8\% was (Aarnink et al., 2008). Uit de berekeningen van de ammoniakemissies per $\mathrm{m}^{2}$ emitterend oppervlak blijkt dat hoogste emissies worden gevonden voor bevuilde vloeroppervlakken. Verder blijkt dat de schuine wanden in de mestkelder ook nog behoorlijk kunnen emitteren, voor zover ze bevuild zijn met urine. Uit de ingeschatte emissie per $\mathrm{m}^{2}$ van het waterkanaal blijkt dat deze emissie niet verwaarloosd mag worden. Het effect van een waterkanaal zal in de praktijk daarom sterk samenhangen met de hoeveelheid water die aan dit mestkanaal wordt toegevoegd in relatie tot de hoeveelheid mest die in dit kanaal terecht komt. Uit dit onderzoek blijkt dat nog een behoorlijk deel van de mest in het waterkanaal terecht komt (gem. 19,3\%).

Bij de biggen wordt de absolute ammoniakemissie gemiddeld iets lager voorspeld dan gemeten. Dit wordt vooral veroorzaakt door een onderschatting van de vloeremissie. Uit het verloop van de ammoniakemissie blijkt dat de vloeremissie vooral bij de tweede keer mestaflaten werd onderschat. Zoals al aangegeven zou dit veroorzaakt kunnen zijn door vervuiling van de kunststof roostervloer richting eind van de ronde waardoor er meer urine achterblijft op de roostervloer, die vervolgens gaat emitteren.

De gemeten resultaten bij de zeugen waren zeer tegenstrijdig en tegen alle verwachtingen in. Dit werd vanaf het begin van het onderzoek al geconstateerd en er is gecheckt of de behandelingen misschien waren omgedraaid. Dit bleek niet het geval. De meest voor de hand liggende reden van de gevonden resultaten (geen effect van de proefbehandeling op de ammoniakemissie en zelfs hogere NH4-N gehalten in de mengmest en de verse urine) is, zoals eerder al aangegeven, dat de verteerbaarheid van het ruw eiwit in het proefvoer hoger was dan berekend op basis van de grondstoffensamenstelling met behulp van de Veevoedertabel. Daarnaast was het opvallend dat het potentieel NH4-N gehalte in de verse urine en het $\mathrm{NH} 4-\mathrm{N}$ gehalte in de urineplassen beduidend lager werden berekend dan gemeten. Dit kan niet worden verklaard doordat de wateruitscheiding te laag is berekend, aangezien de totale berekende mestproductie hoger is ingeschat dan gemeten. Dit zou er op kunnen duiden dat niet alleen de verteerbaarheid van ruw eiwit in het proefvoer te laag is 
berekend, maar tevens de verteerbaarheid van het controlevoer, waarbij de verteerbaarheid in het proefvoer, op basis van de gevonden resultaten, hoger moet zijn dan in het controlevoer.

\subsection{Stand van zaken rekentool}

Het huidige onderzoek heeft aangetoond dat de rekentool bij de verschillende onderzochte varkenscategorieën de ammoniakemissie vrij goed kan voorspellen. Het feit dat met (vrijwel) hetzelfde model voor de verschillende categorieën varkens in dit onderzoek de ammoniakemissie voor al deze categorieën redelijk voorspeld kan worden, betekent dat het model behoorlijk robuust is. Voermaatregelen die gericht zijn op het verlagen van het ammoniumgehalte van urine en mest kunnen goed gesimuleerd worden met het model. Voermaatregelen die gericht zijn op het verlagen van de $\mathrm{pH}$ van urine en mest kunnen nog niet goed gesimuleerd worden. Een tussenoplossing voor dit soort maatregelen zou kunnen zijn om bij deze voeders de $\mathrm{pH}$ van de bulk mest en de bulk urine te meten en vervolgens deze meetgegevens als invoer te gebruiken in het emissiemodel. Om vervolgens een goede schatting te kunnen maken van de $\mathrm{pH}$ van de bovenste laag van urineplassen en mengmest zullen ook een aantal componenten in de mest en de urine moeten worden bepaald, waarbij de belangrijkste zijn het ammonium- en het TIC- (totaal anorganisch koolstof) gehalte. De pH van de bovenste laag van urine en mest zou ook direct gemeten kunnen worden. Hier is echter wel een goede lab-opstelling voor nodig met een nauwkeurige $\mathrm{pH}$-meter die de oppervlakte $\mathrm{pH}$ van de bovenste 0,1 $\mathrm{mm}$ van de mest en urine kan meten.

De huidige rekentool is voldoende robuust om effecten van huisvestings- en voer- en management maatregelen op de ammoniakemissie in te schatten. Aangezien de $\mathrm{pH}$ van urine en mest nog moeilijk is te voorspellen is het verstandig om maatregelen gericht op het verlagen van de $\mathrm{pH}$ te toetsen op de daadwerkelijke verlaging van de $\mathrm{pH}$ van mest en urine. Vervolgens kan met het model de ammoniakemissie worden berekend door deze gemeten $\mathrm{pH}^{\prime} \mathrm{s}$ als invoer in het model te gebruiken.

Verder onderzoek en ontwikkeling van de rekentool zou voornamelijk gericht moeten zijn op het meer inzicht krijgen in de relatie tussen de $\mathrm{pH}$ en de samenstelling van de bulk mest en de $\mathrm{pH}$ van de bovenste laag van de mest. Metingen zullen hierbij niet alleen gedaan moeten worden onder labomstandigheden, maar tevens onder praktijkomstandigheden, aangezien de mate van menging van de urine met de rest van de mest van belang is in het gehele emissieproces. Vooral bij dikke mest zal de urine minder goed mengen met de rest van de mest. Bij het modelmatig vast stellen van effecten van bepaalde maatregelen is het van belang om tussenresultaten van het model, b.v. het ammoniumgehalte van urine en mengmest te toetsen met metingen. Het is modelmatig niet altijd te voorzien welke bij-effecten en interactie-effecten bepaalde voermaatregelen hebben. 


\section{$7 \quad$ Conclusies}

De belangrijkste conclusies uit het onderzoek zijn:

- Vergelijkbare modellen zijn ontwikkeld voor het voorspellen van de ammoniakemissie uit afdelingen voor vleesvarkens, gespeende biggen en drachtige zeugen.

- Gemiddeld berekende totale absolute ammoniakemissiewaarden op jaarbasis komen goed overeen met gemeten waarden.

- Gemiddeld berekende ammoniakemissies vanaf de vloer komen bij vleesvarkens en, in iets mindere mate, bij zeugen goed overeen met de gemeten waarden. Voor biggen werd de vloeremissie te laag ingeschat in de tweede helft van de opfokperiode.

- Het (relatieve) effect van de eiwitbehandeling (verlaagd eiwitgehalte in het voer) kon goed worden ingeschat met het model voor vleesvarkens en biggen. Dit gold voor zowel het effect op de totale emissie als het effect op de vloeremissie. Het effect bij zeugen kon niet goed worden ingeschat. Dit werd waarschijnlijk veroorzaakt door gebruik van verkeerde inputgegevens (te lage verteringscoëfficiënten van het voer). Het gemeten effect van het eiwitgehalte zijn iets hoger dan gemeten in eerdere onderzoeken.

- Het (relatieve) effect van het verzurende voer kan nog niet goed worden voorspeld met het model. Dit wordt voor een deel veroorzaakt door het feit dat het effect van benzoëzuur in het voer op de $\mathrm{pH}$ van de mengmest nog niet is opgenomen in het model. Voor een ander deel wordt dit veroorzaakt door het feit dat de effecten van verzurend voer op de $\mathrm{pH}$ van urine en mengmest op dit moment nog heel moeilijk zijn te voorspellen, vooral omdat een groot aantal factoren hier invloed op kunnen hebben. Vooral het carbonatgehalte van urine en mengmest is moeilijk te voorspellen.

- Het gemeten effect van benzoëzuurtoevoeging (1\%) aan het voer op de ammoniakemissie bij vleesvarkens komt goed overeen met eerder gevonden effecten. Bij toevoeging van benzoëzuur $(0,5 \%)$ aan biggenvoer werd geen effect op de ammoniakemissie gevonden.

- Er lijkt vrijwel geen effect te zijn van het vervangen van Ca-carbonaat door Ca-formiaat aan het voer op de ammoniakemissie.

- Een verlaagd eiwitgehalte in het voer gaf een hogere groei bij vleesvarkens ten opzichte van het controlevoer vooral als gevolg van een hogere voeropname. Het verzurende voer en het combivoer zaten qua groei en voeropname tussen het controlevoer en het verlaagd eiwitvoer in.

- Bij biggen lijkt het verzurende voer een negatieve invloed te hebben op de gezondheid van de dieren. Biggen die het verzurende voer kregen verstrekt moesten significant vaker worden behandeld voor beenwerkproblemen.

- De rekentool kan gebruikt worden om effecten van huisvestings- en voer- en management maatregelen op de ammoniakemissie in te schatten. Voor het bepalen van effecten van voermaatregelen op de $\mathrm{pH}$ van de mest is het model nog onvoldoende geschikt. Als tussenoplossing hiervoor zou de $\mathrm{pH}^{\prime} \mathrm{s}$ van urine en mest gemeten kunnen worden en als input worden gebruikt in het model voor berekening van de ammoniakemissie. 


\section{Aanbevelingen}

Op basis van dit onderzoek kunnen de volgende aanbevelingen worden gedaan:

- De rekentool biedt een goede basis voor het doorrekenen van effecten van (gecombineerde) voer, management- en huisvestingsmaatregelen op de ammoniakemissie uit stallen voor vleesvarkens, gespeende biggen en drachtige zeugen.

- Het is met de huidige rekentool nog niet mogelijk om op basis van de voersamenstelling de $\mathrm{pH}$ van urine en mengmest nauwkeurig te schatten. Vooral het carbonaatgehalte van urine en mengmest, wat een belangrijke invloed heeft op de $\mathrm{pH}$, is moeilijk te schatten. Een tussenoplossing zou kunnen zijn om effecten van voersamenstellingen die de $\mathrm{pH}$ van de mengmest beogen te beïnvloeden om op die manier de ammoniakemissie te verlagen te bepalen door een combinatie van modelberekeningen en metingen. Via metingen in de praktijk wordt het effect van deze voersamenstellingen op de $\mathrm{pH}$ van urineplassen en van de bulk mest gemeten. Deze waarden worden vervolgens als input gebruikt in de rekentool voor bepaling van het effect op de ammoniakemissie.

- Een aantal parameters/variabelen in de rekentool zijn met behulp van de kleinste kwadraten methode of regressieanalyse op verzamelde data in dit onderzoek verkregen. Dezelfde dataset is ook gebruikt voor validatie van de rekentool. Het is aan te bevelen om de rekentool verder te valideren met onafhankelijke datasets. De uitgescheiden hoeveelheid en samenstelling van de mest zou bijvoorbeeld gevalideerd kunnen worden met data die verkregen zijn/worden in respiratie-studies.

- De huidige rekentool is op dit moment vooral bruikbaar in onderzoek. Om deze tool bruikbaar te maken voor andere doelgroepen (overheid, varkenshouders, voorlichters, toeleverend bedrijfsleven) zal de interface, met in- en output, vergaand versimpeld moeten worden. Dit betekent in het algemeen wel een verlies aan flexibiliteit van het model. De precieze in- en output zal daarom goed afgestemd moeten worden met de eindgebruiker.

- De rekentool is goed te gebruiken voor situaties die moeilijk te bemeten zijn, zoals bijvoorbeeld een uitloop voor varkens. Lokaal gemeten variabelen kunnen dan gebruikt worden als input voor het model om de ammoniakemissie in te schatten.

- Het is belangrijk om de rekentool te laten beoordelen door vakgenoten. Dit zou kunnen door de rekentool in één of meerdere artikelen te publiceren in een wetenschappelijke tijdschrift. 


\section{Literatuur}

Aarnink, A.J.A. 1991. Rekenmodel voor de waterbehoefte van vleesvarkens (FYSWA). IMAG-rapport 91-8, Wageningen.

Aarnink, A.J.A., Bikker, P., Van Diepen, J.T.M. 2012. Voermaatregelen voor ammoniakreductie in stallen voor zeugen en biggen. Wageningen UR Livestock Research. Rapport 591.

Aarnink, A.J.A., Elzing, A. 1998. Dynamic model for ammonia volatilization in housing with partially slatted floors, for fattening pigs. Livest. Prod. Sci. 53: 153-169.

Aarnink, A.J.A., Hol, J.M.G., Huis in 't Veld, J.W.H. 2006a. Effect of benzoic acid (VevoVitall) in the diet of growing-finishing pigs on ammonia emission. Animal Sciences Group, Divisie Veehouderij. Report 6305309502.

Aarnink, A.J.A., Hol, J.M.G., Nijeboer, G.M. 2008. Ammonia emission factor for using benzoic acid (1\% VevoVitall) in the diet of growing-finishing pigs. Animal Sciences Group, Divisie Veehouderij.

Aarnink, A.J.A., Hol, J.M.G., Nijeboer, G.M., Mosquera, J. 2015. Ammoniakemissie uit varkensstallen met uitloop. Wageningen UR (University \& Research centre), Rapport 868.

Aarnink, A.J.A., Schrama, J.W., Heetkamp, M.J.W., Stefanowska, J., Huynh , T.T.T. 2006b. Temperature and body weight affect fouling of pig pens. Journal of Animal Science, 84, 2224-2231.

Aarnink, A.J.A., Smits, M.C.J., Vermeij, I. 2010. Reductie van ammoniakemissie op vleesvarkensbedrijven via gecombineerde maatregelen. Rapport 366.

Aarnink, A.J.A., Swierstra, D., Van den Berg, A.J., Speelman, L. 1997. Effect of type of slatted floor and degree of fouling of solid floor on ammonia emission rates from fattening piggeries. J. agric. Engng Res. 1997, 66: 93-102.

Aarnink, A.J.A., Van Ouwerkerk, E.N.J., Verstegen, M.W.A. 1992. A mathematical model for estimating the amount and composition of slurry from fattening pigs. Livest. Prod. Sci., 31, 133-147.

Aarnink, A.J.A., Verstegen, M.W.A. 2007. Nutrition, key factor to reduce environmental load from pig production. Livestock Sciences, 109, 194-203.

Albright, L.D. 1990. Environment control for animals and plants. ASAE, St. Joseph Mich.

Anonymus. 2016. CVB Veevoedertabel 2016. Chemische samenstellingen en nutritionele waarden van voedermiddelen. Uitgave Centraal Veevoederbureau in Nederland.

Bakker, G.C.M., Hol, J.M.G., Smits, M.C.J., Jongbloed, A.W. 2005. De addiviteit van voedingsmaatregelen om de ammoniakemissie te verlagen uit varkensstallen. 2 . Stalmetingen en in vitro ammoniakemissie bij drie rantsoenen. Animal Sciences Group, Wageningen UR. Rapport 03/0000003.

Beeking, F.F.E., Ingelaat, F.B.J.M., van Beek, G. 1994. De specifieke vochtafgifte van leghennenmest [Specific moisture production from layer litter]. Report 607, COVP-DLO, Beekbergen.

Braam, C.R., Swierstra, D. 1999. Volatilization of ammonia from dairy housing floors with different surface characteristics. J. Agric. Engng Res. 72: 59-69.

CIGR. 2002. Heat and moisture production at animal and house levels. CIGR Working Group on Climatization of Animal Houses.

De Lange, C., Morel, P., Birkett, S. 2003. Modeling chemical and physical body composition of the growing pig. Journal of Animal Science, 81(14_suppl_2), E159-E165.

Ferguson, N., Gous, R. 1993. Evaluation of pig genotypes 2. Testing experimental procedure. Animal Production, 56(02), 245-249.

Ferguson, N., Kyriazis, S. 2003. Evaluation of the growth parameters of six commercial crossbred pig genotypes 1. Under commercial housing conditions in individual pens. South African Journal of Animal Science, 33(1), 11-20.

Fowler, V., Fuller, M., Close, W., Whittemore, C. 2013. Energy requirements for the growing pig. Energy metabolism. Proceedings of the 8th symposium. European association of animal production, publication. pp. 151-156.

Genstat Committee. 2015. GenStat Release 18.1. VSN International Ltd, Hemel Hempstead, UK.

Groenestein, C.M., Aarnink, A.J.A., Ogink, N.W.M. 2014. Actualisering ammoniakemissiefactoren vleesvarkens en biggen Wageningen UR Livestock Research, rapport 786.

Groenestein, K., Aarnink, A.J.A. 2008. Notitie over leegstand ten behoeve van het berekenen van een emissiefactor van een stal. Intern rapport 200808, Animal Science Group van Wageningen UR. Intern rapport 200808.

Hafner, S.D., Montes, F., Rotz, C.A. 2013. The role of carbon dioxide in emission of ammonia from manure. Atmospheric Environment, 66, 63-71. 
Husted, S.L.S.J., Jo/rgensen, S.S. 1991. Reducing ammonia loss from cattle slurry by the use of acidifying additives: the role of the buffer system. J. Sci. Fd Agric. 57: 335-349.

Huynh, T.T.T., Aarnink, A.J.A., Verstegen, M.W.A., Gerrits, W.J.J., Heetkamp, M.J.W., Kemp, B., Truong, C.T. 2005. Effects of increasing temperatures on pigs' physiological changes at different relative humidities. Journal of Animal Science, 83, 1385-1396.

Kielanowski, J. 1965. Estimates of the energy cost of protein deposition in growing animals. Proceedings of the 3rd Symposium on Energy Metabolism. EAAP Publ. no. 11. Academic Press, London, UK. pp. 1320.

Murphy, D.P., O'Doherty, J.V., Boland, T.M., O'Shea, C.J., Callan, J.J., Pierce, K.M., Lynch, M.B. 2011. The effect of benzoic acid concentration on nitrogen metabolism, manure ammonia and odour emissions in finishing pigs. Animal Feed Science and Technology, 163(2-4), 194-199.

Noblet, J., Dourmad, J., Etienne, M., Le Dividich, J. 1997. Energy metabolism in pregnant sows and newborn pigs. Journal of animal science, 75(10), 2708-2714.

Ogink, N.W.M., Mosquera, J., Hol, J.M.G. 2013. Protocol voor meting van ammoniakemissie uit huisvestingssystemen in de veehouderij 2013. Livestock Research. 621.

Olesen, J.E., Sommer, S.G. 1993. Modelling effects of wind speed and surface cover on ammonia volatilization from stored pig slurry. Atmospheric Environment vol. 27A, no. 16, p. 2567-2574.

Petersen, V., Markfoged, R., Hafner, S.D., Sommer, S.G. 2014. A new slurry pH model accounting for effects of ammonia and carbon dioxide volatilization on solution speciation. Atmospheric Environment, DOI 10.1007/s10705-014-9637-6.

Quiniou, N., Noblet, J., Dourmad, J.-Y., Van Milgen, J. 1999. Influence of energy supply on growth characteristics in pigs and consequences for growth modelling. Livestock Production Science, 60(2), 317-328.

Smits, M.C.J., Hol, J.M.G., Van der Peet-Schwering, C.M.C., Aarnink, A.J.A. 2012. Invloed van eiwitgehalte en toevoeging calciumchloride op de ammoniakemissie uit vleesvarkensstallen. Rapport 588.

Van Milgen, J., Noblet, J. 2003. Partitioning of energy intake to heat, protein, and fat in growing pigs. Journal of Animal Science, 81(14_suppl_2), E86-E93.

van Milgen, J., Valancogne, A., Dubois, S., Dourmad, J.-Y., Sève, B., Noblet, J. 2008. InraPorc: A model and decision support tool for the nutrition of growing pigs. Animal Feed Science and Technology, 143(1), 387-405. 


\section{Bijlagen}

Bijlage 1: Schematische weergave van de rekentool met daarin de belangrijkste input, output en te berekenen modelvariabelen

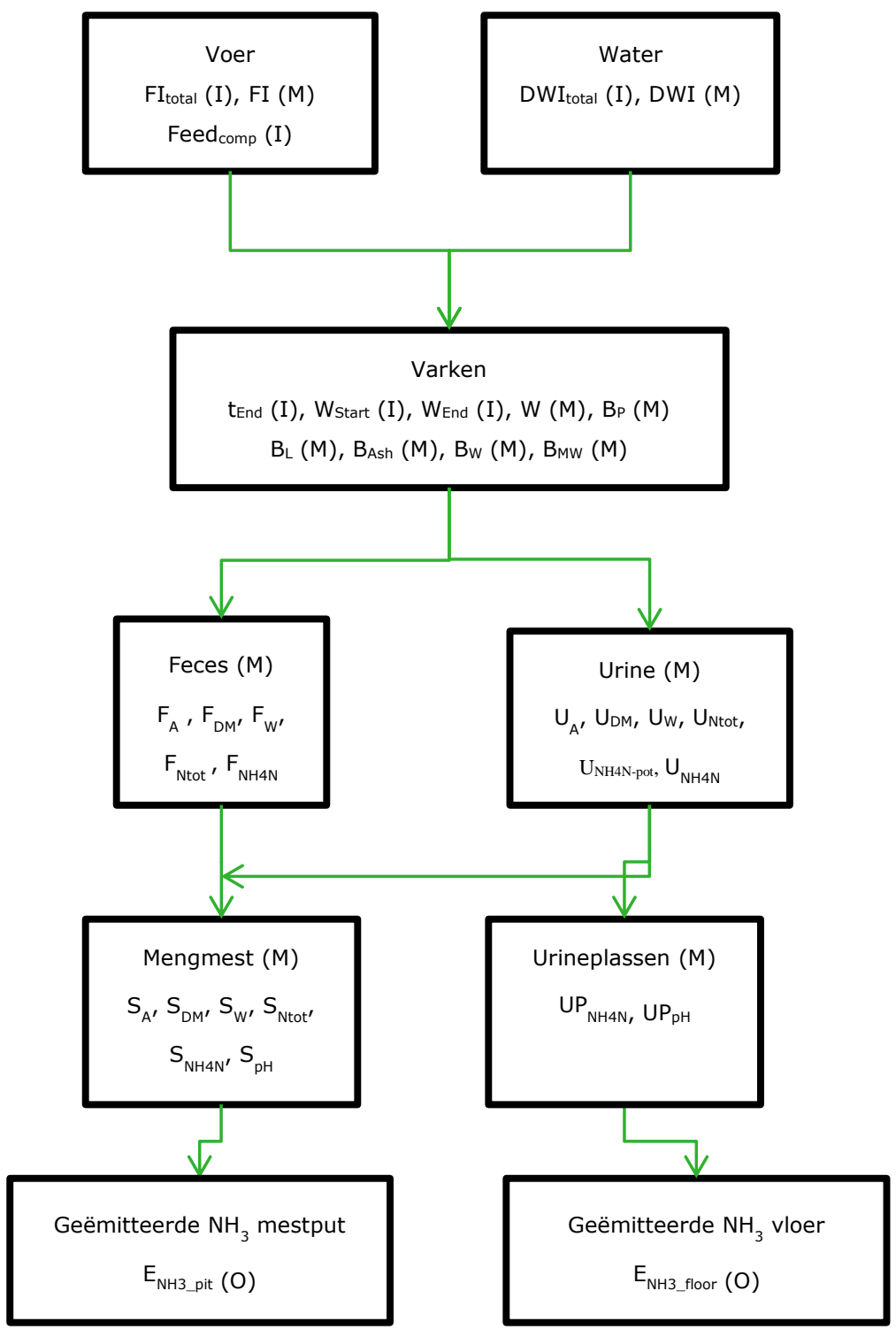

Figuur 1. Schematische weergave van de opbouw van de rekentool voor schatting van de ammoniakemissie uit varkensstallen waarin de belangrijkste input (I), output (O) en intern te berekenen modelvariabelen (M) zijn weergegeven. Voor uitleg van de symbolen zie tabel 1. 
Tabel 1

De betekenis van de gebruikte symbolen in figuur 1. Alle variabelen zijn, voor zover relevant, uitgedrukt per varken.

\begin{tabular}{|c|c|c|c|}
\hline Symbool & Betekenis & Symbool & Betekenis \\
\hline $\mathrm{B}_{\text {Ash }}$ & Aanzet anorganische stof $(\mathrm{kg} / \mathrm{d})$ & $\mathrm{S}_{\mathrm{NH} 4 \mathrm{~N}}$ & $\begin{array}{l}\text { Ammonium stikstof uitscheiding in } \\
\text { mest }(\mathrm{kg} / \mathrm{d})\end{array}$ \\
\hline BEvap & Waterverdamping door dier $(\mathrm{kg} / \mathrm{d})$ & $\mathrm{S}_{\mathrm{N} \text { tot }}$ & $\begin{array}{l}\text { Totaal stikstof uitscheiding in mest } \\
(\mathrm{kg} / \mathrm{d})\end{array}$ \\
\hline $\mathrm{B}_{\mathrm{L}}$ & Vetaanzet $(\mathrm{kg} / \mathrm{d})$ & $\mathrm{S}_{\mathrm{pH}}$ & $\mathrm{pH}$ van mengmest (-) \\
\hline BMW & $\begin{array}{l}\text { Productie metabolisch water in dier } \\
(\mathrm{kg} / \mathrm{d})\end{array}$ & Sw & Wateruitscheiding in mest $(\mathrm{kg} / \mathrm{d})$ \\
\hline $\mathrm{Bp}$ & Eiwitaanzet (kg/d) & $t_{\text {End }}$ & Groeiperiode vleesvarken (dagen) \\
\hline $\mathrm{B}_{\mathrm{w}}$ & Wateraanzet $(\mathrm{kg} / \mathrm{d})$ & $\mathrm{U}_{\mathrm{A}}$ & Urineproductie (kg/d) \\
\hline DWI & Drinkwateropname $(\mathrm{kg} / \mathrm{d})$ & $\mathrm{U}_{\mathrm{DM}}$ & Drogestofuitscheiding in urine $(\mathrm{kg} / \mathrm{d})$ \\
\hline DWI total & $\begin{array}{l}\text { Totale drinkwateropname tijdens } \\
\text { groeiperiode }(\mathrm{kg})\end{array}$ & $U_{\text {Ntot }}$ & $\begin{array}{l}\text { Totaal stikstof uitscheiding via urine } \\
(\mathrm{kg} / \mathrm{d})\end{array}$ \\
\hline $\mathrm{E}_{\mathrm{NH} 3}$ & Ammoniakemissie (mg/uur) & $U_{\mathrm{NH} 4 \mathrm{~N}}$ & $\begin{array}{l}\text { Totaal ammoniumstikstof } \\
\text { uitscheiding via urine }(\mathrm{kg} / \mathrm{d})\end{array}$ \\
\hline $\mathrm{F}_{\mathrm{A}}$ & Fecesproductie (kg/d) & $\mathrm{U}_{\mathrm{pH}}$ & $\mathrm{pH}$ van urine $(-)$ \\
\hline $\mathrm{F}_{\mathrm{DM}}$ & $\begin{array}{l}\text { Drogestofuitscheiding in feces } \\
(\mathrm{kg} / \mathrm{d})\end{array}$ & $\mathrm{U}_{\mathrm{NH} 4 \mathrm{~N}-\mathrm{pot}}$ & $\begin{array}{l}\text { Potentiële NH4-N uitscheiding in } \\
\text { urine (totaal van NH4-N en ureum- } \\
\text { N) }(\mathrm{kg} / \mathrm{d})\end{array}$ \\
\hline $\mathrm{F}_{\mathrm{NH} 4 \mathrm{~N}}$ & $\begin{array}{l}\text { Totaal ammoniumstikstof } \\
\text { uitscheiding via feces }(\mathrm{kg} / \mathrm{d})\end{array}$ & Uw & Wateruitscheiding in urine $(\mathrm{kg} / \mathrm{d})$ \\
\hline $\mathrm{F}_{\mathrm{Ntot}}$ & $\begin{array}{l}\text { Totaal stikstof uitscheiding via } \\
\text { feces }(\mathrm{kg} / \mathrm{d})\end{array}$ & $\mathrm{UP}_{\mathrm{NH} 4 \mathrm{~N}}$ & $\begin{array}{l}\text { Ammoniumstikstofconcentratie } \\
\text { urineplas }(\mathrm{g} / \mathrm{kg})\end{array}$ \\
\hline $\mathrm{Fw}$ & Wateruitscheiding in feces $(\mathrm{kg} / \mathrm{d})$ & $U P_{p H}$ & $\mathrm{pH}$ urineplas (-) \\
\hline Feed $_{\text {comp }}$ & $\begin{array}{l}\text { Concentratie en v.c.'s }{ }^{1)} \text { van } \\
\text { voercomponenten in voer }(\mathrm{kg} / \mathrm{kg})^{2)}\end{array}$ & $W_{\text {End }}$ & Eindgewicht vleesvarken (kg) \\
\hline FI & Voeropname $(\mathrm{kg} / \mathrm{d})$ & $W_{\text {Start }}$ & Begingewicht vleesvarken (kg) \\
\hline FI total & $\begin{array}{l}\text { Totale voeropname tijdens } \\
\text { groeiperiode }(\mathrm{kg})\end{array}$ & W & Gewicht (kg) \\
\hline $\mathrm{S}_{\mathrm{A}}$ & $\begin{array}{l}\text { Mestproductie (feces + urine) } \\
(\mathrm{kg} / \mathrm{d})\end{array}$ & & \\
\hline $\mathrm{S}_{\mathrm{DM}}$ & $\begin{array}{l}\text { Drogestofuitscheiding in mest } \\
(\mathrm{kg} / \mathrm{d})\end{array}$ & & \\
\hline
\end{tabular}

1) v.c. = verteringscoëfficiënt

2) Voercomponenten: water, ruw-eiwit, ruw-vet, ruwe celstof, as, fosfor, kalium en overige koolhydraten. 


\section{Bijlage 2: Resultaten van het pH onderzoek in Denemarken}

SDU work on "Rekentool voor het bepalen van de effecten van voer- en managementmaatregelen op de ammoniakemissie bij varkens: ontwikkeling en validatie"

Sasha D. Hafner, 25 September 2017

\section{$\underline{\text { Overview }}$}

This document describes the work carried out at SDU. There were four components: characterization of slurry, prediction of bulk $\mathrm{pH}$, prediction of surface $\mathrm{pH}$ in slurry, and measurement of $\mathrm{pH}$ profiles in slurry.

\section{Characterization of slurry}

Slurry samples were analyzed for $\mathrm{pH}$, total inorganic carbon (TIC), and buffer capacity. TIC affects pH, buffering, and also the elevation of slurry surface by $\mathrm{CO}_{2}$ emission. Effects of diets on $\mathrm{NH}_{3}$ emission could be facilitated by changes in these two variables. Additionally, measurement of buffer capacity provides a means to test our understanding of the factors controlling slurry $\mathrm{pH}$. With measurement of all important solutes, it should be possible to accurately predict buffering by slurry.

\section{Prediction of bulk pH}

Given the exact composition of slurry, it is possible to calculate bulk pH. In practice, however, it is not reasonable to expect that the exact composition can be determined. For example, some large organic acids may not be identified. But it is important to know how accurately $\mathrm{pH}$ can be predicted based on measurement of slurry composition. For the calculation tool described in this report, an empirical approach to calculating $\mathrm{pH}$ is probably a better fit.

\section{Prediction of surface $\mathrm{pH}$}

It is known that surface $\mathrm{pH}$ is generally higher than bulk $\mathrm{pH}$ in slurry undergoing emission of $\mathrm{CO}_{2}$ and $\mathrm{NH}_{3}$. This elevation in $\mathrm{pH}$ can significantly affect ammonia emission. A reaction-transport model has been developed for predicting this elevation, as well as the effect on ammonia emission (Hafner et al. 2012). However, given its complexity and long run time, it is not feasible to incorporate the model into the calculation tool described in this work. Therefore, our objective was to develop a simple empirical regression model to predict surface $\mathrm{pH}$.

\section{Measurement of $\mathrm{pH}$ profiles in pig slurry}

Laboratory experiments were carried out to measure $\mathrm{pH}$ profiles in pig slurry during emission of $\mathrm{NH}_{3}$ and $\mathrm{CO}_{2}$. Although it is not possible to exactly replicate the conditions of slurry within the pits within the pig houses used in the main experiments, these trials serve to demonstrate that $\mathrm{pH}$ elevation does occur, and provide some estimate of the magnitude of the increase in surface $\mathrm{pH}$.

\section{Methods}

\section{Characterization of slurry}

Pig slurry samples were frozen soon after collection. After thawing, TIC was measured with a modified version of the method described by Hafner and Bisogni (2007). The exact steps were as follows.

1. $10-30 \mathrm{~g}$ of slurry was placed in a glass bottle $(116 \mathrm{~mL})$ or vial $(64 \mathrm{~mL})$ and the exact mass added was determined by mass difference. For dry samples, some deionized water was also added to ensure sufficient mixing.

2. $3 \mathrm{~mol} / \mathrm{L} \mathrm{HCl}$ was added (at least $2 \mathrm{~mL}$ of acid per $10 \mathrm{~mL}$ sample) using a needle and syringe, and the bottle was inverted when removing the needle to prevent gas leakage

3. The bottle was shaken vigorously for 30 seconds, then allowed to sit for 10 minutes

4. The bottle was shaken again for 30 seconds, then allowed to sit for 10 minutes

5. Finally, the headspace pressure was measured with an electronic manometer (Dwyer, Michigan City, IN, USA).

Total inorganic carbon in the sample was then calculated from headspace pressure, considering the total gas composition ( $\mathrm{CO}_{2}$ and air) as well as the volume of acid added. Partitioning of $\mathrm{CO}_{2}$ between the solution and gas phases was also included in the calculation. 
Buffer capacity was taken here as the response of $\mathrm{pH}$ to addition of $\mathrm{NaOH}$. A known mass of 1.0 $\mathrm{mol} / \mathrm{kg} \mathrm{NaOH}(3.1 \mathrm{~g})$ was added to $90 \mathrm{~g}$ of slurry. Initial and final $\mathrm{pH}$ and temperature were measured while stirring. The buffer capacity was calculated as the dose of $\mathrm{NaOH}$ required for a 1 unit increase in $\mathrm{pH}$. Units were $\mathrm{mmol} / \mathrm{kg}$ per $\mathrm{pH}$ unit. Initial $\mathrm{pH}$ was used as a measurement of bulk $\mathrm{pH}$.

\section{Prediction of bulk $\mathrm{pH}$}

We used the geochemical reaction-transport model PHREEQC (Charlton and Parkhurst, 2011; Parkhurst and Appelo, 2013). The Deby-Hückel model was used for non-ideal behavior (constants from Hafner et al., 2012). To calculate $\mathrm{pH}$, the following reactants were used: $\mathrm{CO}_{2}, \mathrm{NH}_{3}$, acetic acid, propionic acid, butyric acid, isobutyric acid, $\mathrm{K}, \mathrm{Na}, \mathrm{Ca}$, phosphate, and $\mathrm{Cl}$. Cations were added as hydroxides, phosphate as phosphoric acid, and $\mathrm{Cl}$ as $\mathrm{HCl}$, to maintain charge balance. Additionally, we calculated the additional quantity of strong acid $(\mathrm{HCl})$ that would be required to reach the measured $\mathrm{pH}$. Measured $\mathrm{pH}$ was taken as the $\mathrm{pH}$ measured in the laboratory at SDU, which should most closely correspond to measured TIC.

\section{Prediction of surface $\mathrm{pH}$}

To develop a regression model, we used the reaction-transport model of Hafner et al. (2012) to predict surface $\mathrm{pH}$ for pig slurry under typical conditions. The emission rate of $\mathrm{NH}_{3}$ is proportional to the gas-phase concentration of $\mathrm{NH}_{3}$ in equilibrium with $\mathrm{NH}_{3}(\mathrm{aq})$ in the surface of the slurry:

$$
j_{\mathrm{NH}_{3}}=h_{m} \mathrm{C}_{\mathrm{NH}_{3}}
$$

In Eq. (1), $j_{\mathrm{NH}_{3}}$ is the flux of $\mathrm{NH}_{3}$ from the slurry surface, $h_{m}$ is the mass transfer coefficient for convection from the surface, and $c_{\mathrm{NH}_{3}}$ is the $\mathrm{NH}_{3}$ (aq) concentration as the slurry surface. An analogous equation is used for $\mathrm{CO}_{2}$. The model is a 1-dimensional numerical model, with transport among layers by diffusion within the slurry, and convection from the upper-most layer. Concentrations of $\mathrm{NH}_{3}$ and $\mathrm{CO}_{2}$ at any time and location are dependent on speciation and transport. Speciation calculations determine the concentrations based on TAN and TIC and pH. All reactions are assumed to be at equilibrium with the exception of $\mathrm{CO}_{2}$ hydration/dehydration, which was assumed to be uncatalyzed. Model inputs include TIC and TAN concentration, bulk pH, and the mass transfer coefficient (Table 1).

\section{Table 1}

Ranges used for input variables for reaction-transport model predictions. Four values were used for each variable, with linear spacing for all except the convection coefficient, which used logarithmic spacing.

\begin{tabular}{lrcc} 
& Units & Minimum & Maximum \\
Variable & $\mathrm{g} / \mathrm{kg}$ & 0.7 & 7.0 \\
\hline TIC conc. & $\mathrm{g} / \mathrm{kg}$ & 0.6 & 3.6 \\
\hline Bulk pH & - & 6.0 & 9.0 \\
\hline Mass transfer coef. $*$ & $\mathrm{~m} / \mathrm{s}$ & $10^{-4}$ & $10^{-2}$
\end{tabular}

Notes: *The value is specified for $\mathrm{NH}_{3}$, and set to $62 \%$ of this value for $\mathrm{CO}_{2}$, based on the inverse ratio of the square root of molecular weight.

A total of 256 simulations were run for a simulated time of 3 hours for all combinations of the four levels used for each of the four input variables. Initial $\mathrm{pH}$ was adjusted with either acetic acid or $\mathrm{KOH}$ as needed to match the desired value. Transport through the liquid phase was assumed to be diffusion controlled to a depth of $10 \mathrm{~cm}$, beyond which slurry was assumed to be well-mixed with constant, bulk, concentrations of solutes and the bulk $\mathrm{pH}$. Total computer time for running these simulations was several hours. Resulting predictions of surface $\mathrm{pH}$ were taken as observations for development of the regression model. Predictors included TAN and TIC concentrations and bulk pH. Linear terms, logtransformed terms, and first-order interactions were all considered. Akaike information criterion (AIC) and Wald-type tests (backward elimination) were both used to reduce the number of model parameters.

\section{Measurement of $\mathrm{pH}$ profiles in pig slurry}

Prior to measuring $\mathrm{pH}$ profiles samples were placed at room temperature in the laboratory and allowed to thaw (usually overnight). Slurry was then mixed by shaking, and carefully poured in a $100 \mathrm{~mL}$ 
beaker so the upper surface of slurry was $10 \mathrm{~mm}$ from the beaker edge. Beakers were held at room temperature for 3 hours, exposed to the laboratory air the entire time. After this time, $\mathrm{pH}$ in the top $20 \mathrm{~mm}$ was measured using a glass microelectrode (50 $\mu \mathrm{m}$ tip) and an electronically controlled micromanipulator (Unisense, Aarhus, Denmark) over a period of 20-30 min. The electrode was calibrated before each measurement. After the measurements, slurry bulk pH was measured using a glass macroelectrode (Orion ROSS Sureflow, Beverly, MA, USA) near the bottom of the slurry sample. Microelectrode measurements were later adjusted to match the bulk values at the deepest location. This adjustment served to correct for drift in the microelectrode. The convection coefficient for emission was determined based on measurement of mass loss from similar $100 \mathrm{~mL}$ beakers containing acetone. Mass was measured several times during the exposure period.

Model predictions for select profiles were made using the $\mathrm{R}$ version of the model described by Hafner et al. (2012). Simulations used the measured convection coefficient $\left(10^{-3} \mathrm{~m} / \mathrm{s}\right)$, measured TAN and TIC concentrations, and measured bulk $\mathrm{pH}$. The effective diffusion coefficient and relative rate of $\mathrm{CO}_{2}$ hydration $/ \mathrm{H}_{2} \mathrm{CO}_{3}$ dehydration were adjusted to provide the best fit to the measurements, as in Hafner et al. (2016).

\section{$\underline{\text { Results and discussion }}$}

\section{Characterization of slurry}

Both slurry $\mathrm{pH}$ and buffer capacity showed variation among diets and over time (Figs. 1 and 2). In growing-finishing pigs and pregnant sows, the altered diets generally reduced slurry $\mathrm{pH}$. For weaned piglets, only the addition of benzoic acid provided some evidence of reducing slurry $\mathrm{pH}$.

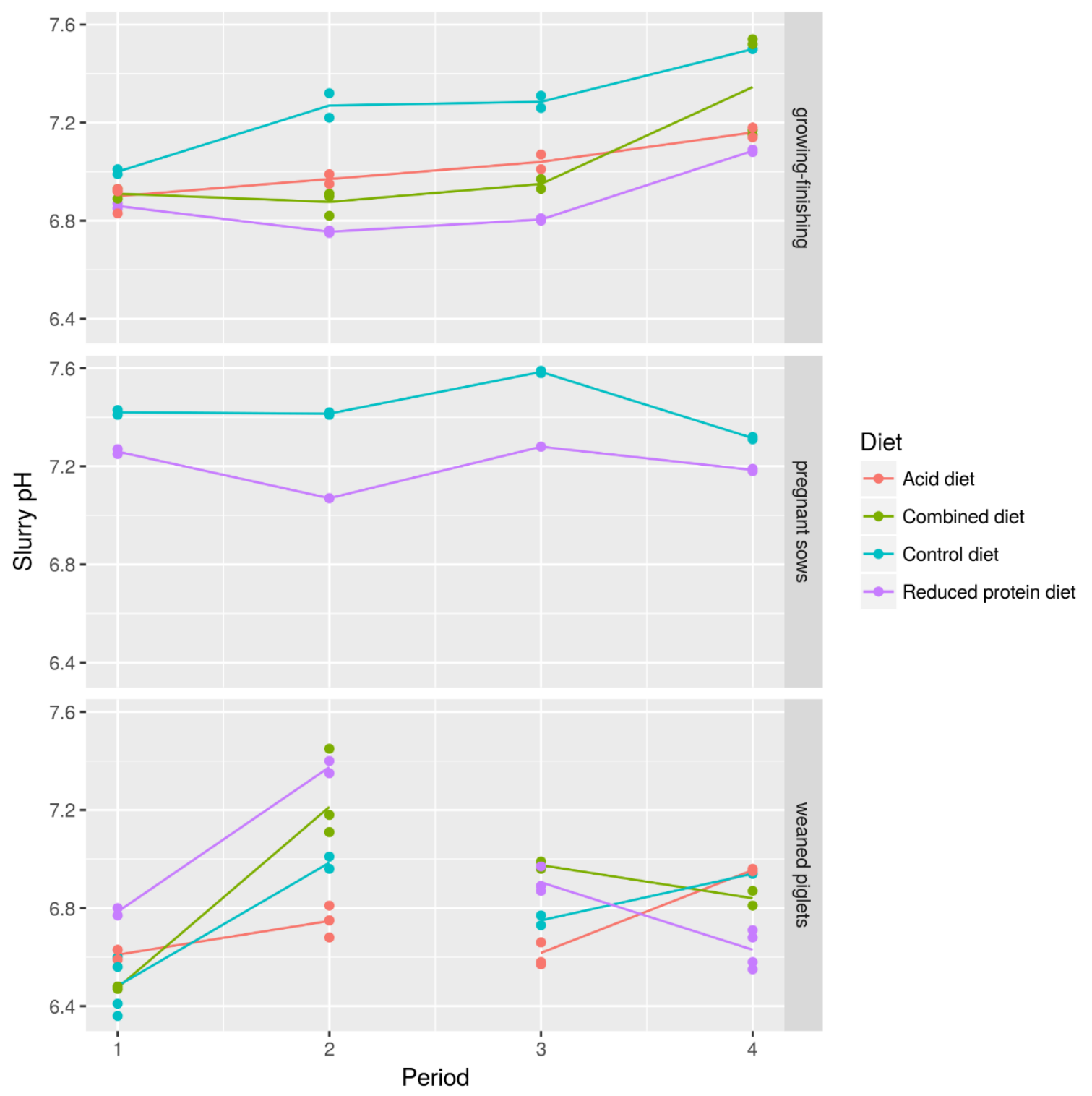

Figure 1. Slurry $\mathrm{pH}$ measured in stored samples. 


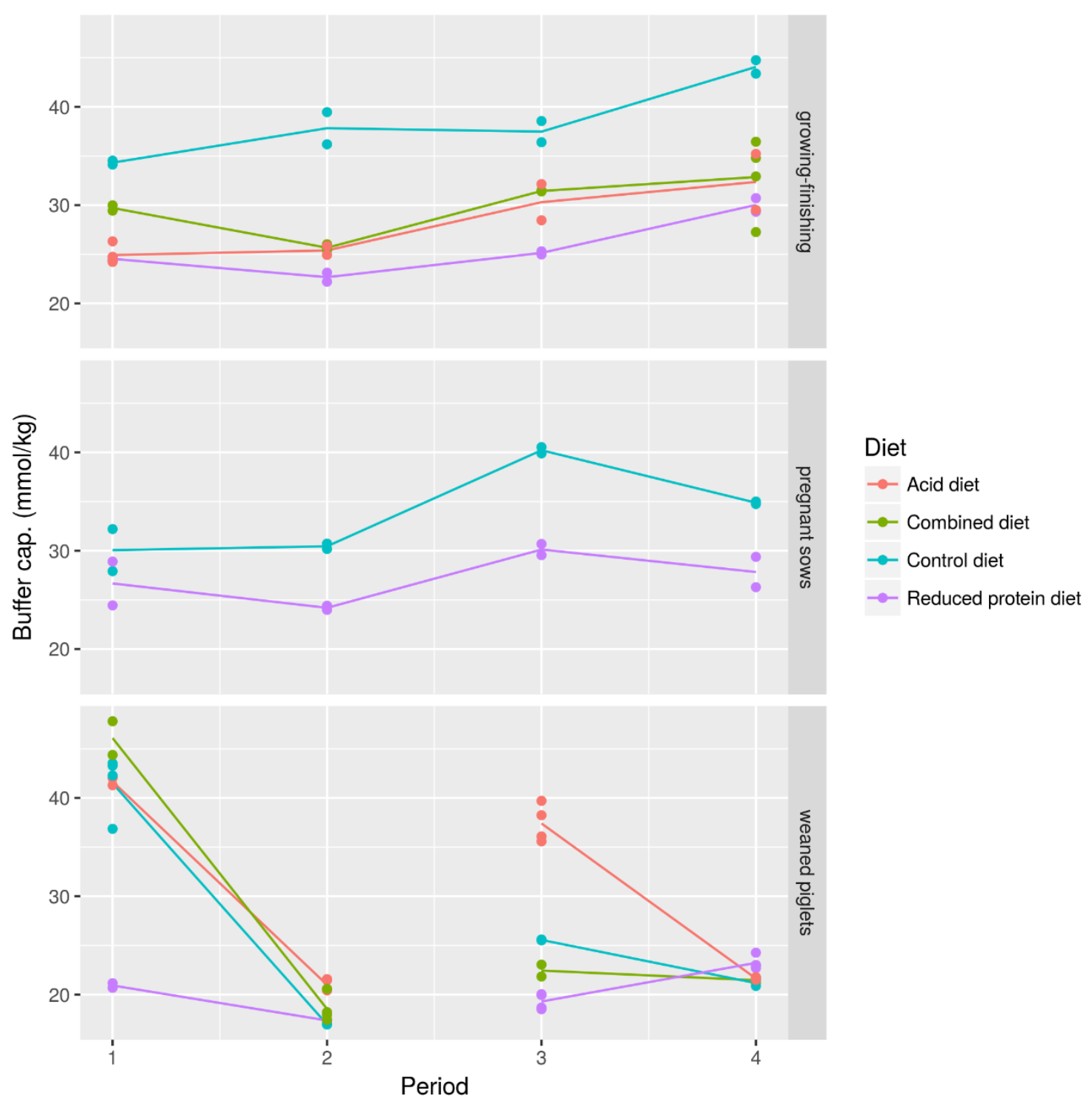

Figure 2. Slurry buffer capacity measured in stored samples.

Prediction of bulk pH

Surprisingly, equilibrium speciation predictions of bulk $\mathrm{pH}$ were much higher than measured values (Table 2). The dose of $\mathrm{HCl}$ required to reach the measured $\mathrm{pH}$ was high-approximately half of the concentration of TAN (Fig. 3). These results suggest either an inaccurate quantification of slurry solutes, or the presence of an additional acidic component that was not measured. Complex acidic functional groups associated with dissolved organic matter could have contributed to the observed $\mathrm{pH}$, but the magnitude of the missing acid is surprisingly large. This topic needs additional work. 


\section{Table 2}

Measured slurry $\mathrm{pH}$ and values calculated from the speciation model PHREEQC based on measured slurry composition. All calculated values were significantly higher than measured $\mathrm{pH}$.

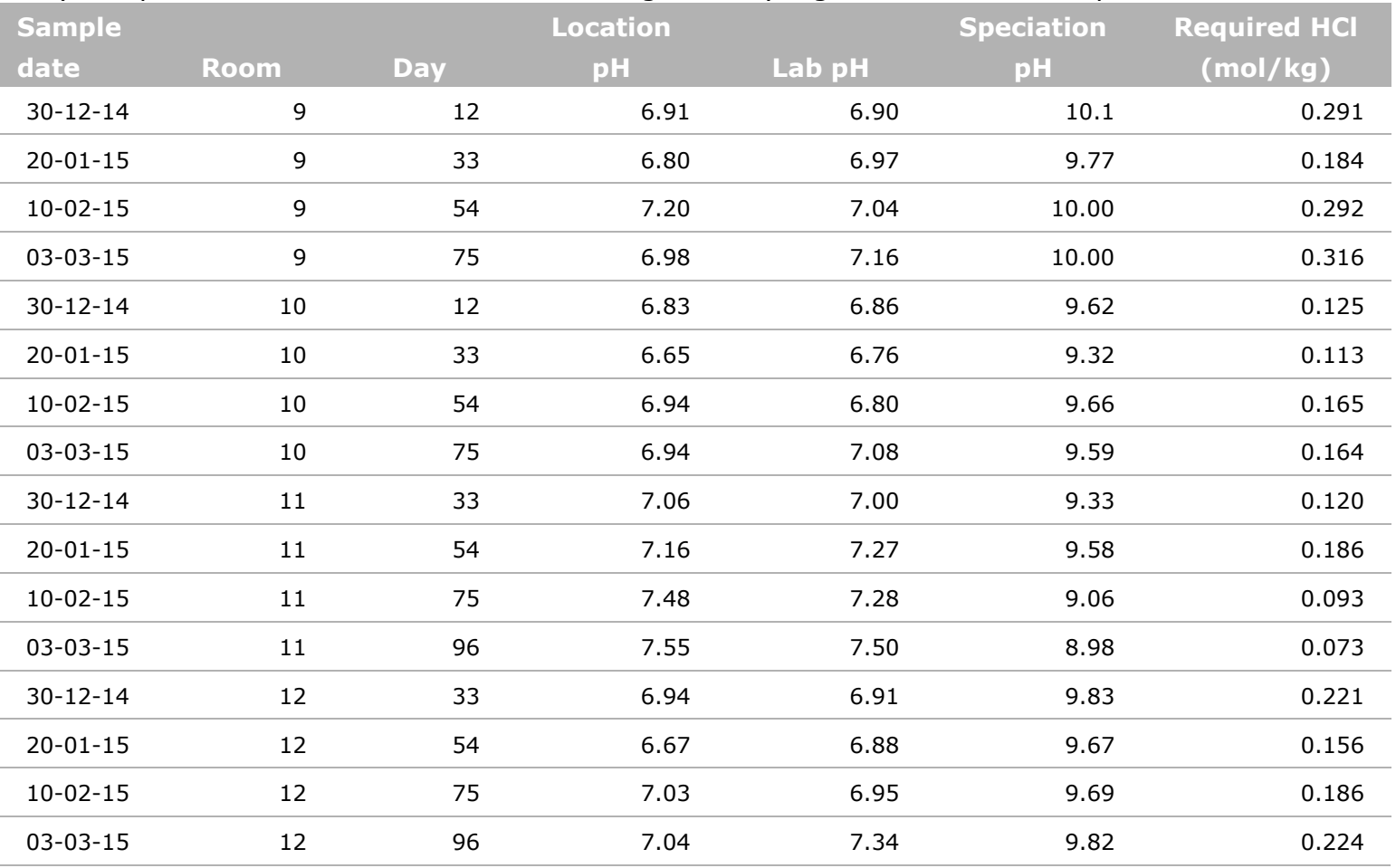

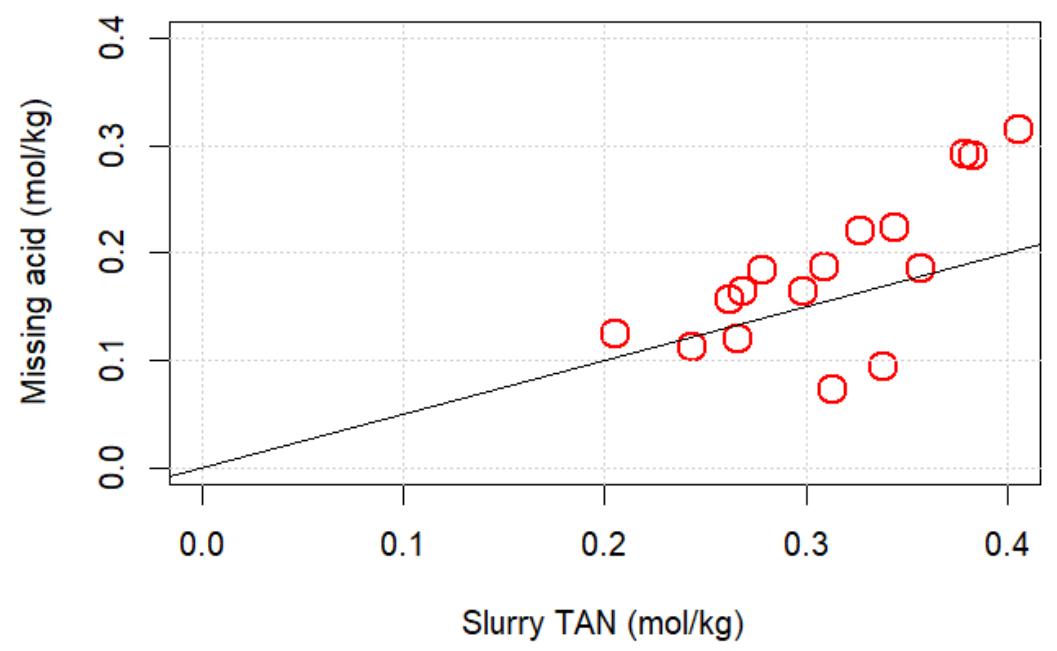

Figure 3. Apparent missing acid from slurry in order to match measured $\mathrm{pH}$ versus measured TAN concentration. Line is 0.5:1.

We developed empirical models for predicting bulk $\mathrm{pH}$ of slurry based on readily-available measurements. The $\mathrm{pH}$ measured on location after emptying the pit was related to slurry TAN, TIC, and acetic acid concentrations (Eq. (42)).

Prediction of surface $\mathrm{pH}$

Several models were developed to predict slurry surface $\mathrm{pH}$. The following model provided a good fit $\left(R^{2}=0.986\right)$ :

Surface $\mathrm{pH}=5.56185-112.818 * \mathrm{pH}$. bulk $+483.846 * \log 10(\mathrm{pH}$. bulk $)+2.37385 * \log 10(\mathrm{TIC})-$ $0.478592 * \log 10($ TAN $)+64.8095 * \mathrm{pH}$. bulk*log $10(\mathrm{pH}$. bulk $)-2.09968 * \log 10(\mathrm{pH}$. bulk $) * \log 10($ TIC) However, it requires knowledge of slurry TIC, which is typically not available. Instead, a much simpler model (Eq. (44)) was used. The fit of this model was much poorer $\left(R^{2}=0.517\right)$, but the only required 
input is bulk $\mathrm{pH}$. All of these models include assumptions about slurry mixing and the air-phase convection coefficient that have significant effects on model predictions. More work is needed to understand these interactions.

Measurement of pH profiles in pig slurry

Microelectrode measurements showed that surface $\mathrm{pH}$ increased significantly above bulk $\mathrm{pH}$ within three hours. Results for the three different diets collected on the same day are shown below (Fig. 4). Calculation of best-fit effective diffusivity ranged from $6.4 \cdot 10^{-10}$ to $9.7 \cdot 10^{-10} \mathrm{~m}^{2} / \mathrm{s}$, which were smaller than the expected value of $2.0 \cdot 10^{-9} \mathrm{~m}^{2} / \mathrm{s}$. There was little evidence of catalysis of $\mathrm{H}_{2} \mathrm{CO}_{3}$ dehydration. Best-fit rates were from 0.6 to 2.1 -fold uncatalyzed rates. Use of uncatalyzed rates shifted $\mathrm{pH}$ only slightly ( $<0.2 \mathrm{pH}$ units). Carbonic anhydrase, conversely, can increase rates by several orders of magnitude above uncatalyzed rates.

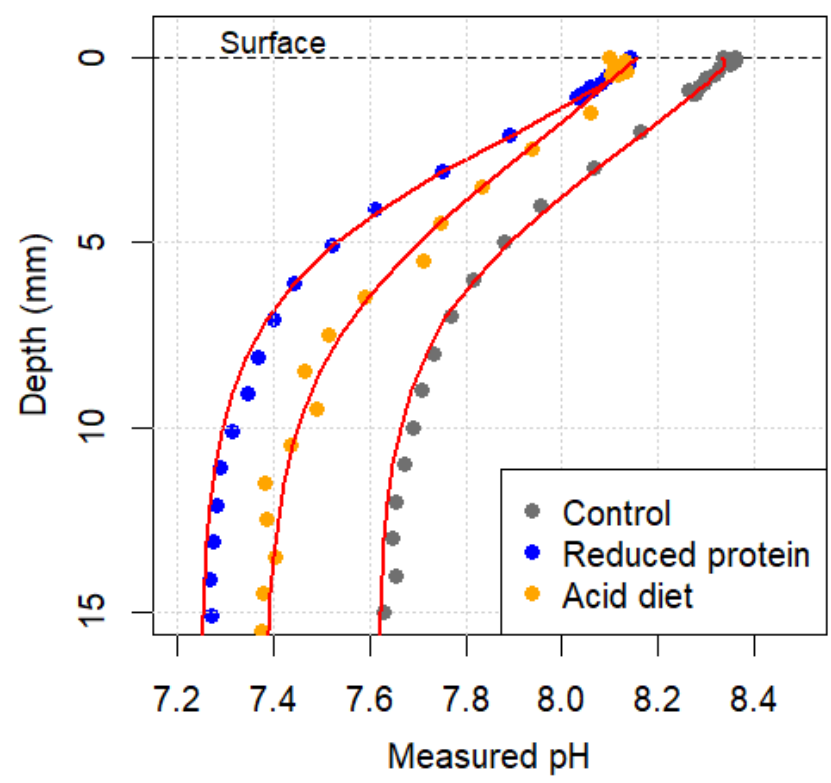

Figure 4. Measured (points) and calculated (lines) $\mathrm{pH}$ within the upper $15 \mathrm{~mm}$ of pig slurry taken from the slurry pits for pigs fed three different diets.

\section{References}

Hafner, S. D. and Bisogni, J. J.: A Simple Method for Measurement of Inorganic Carbon Concentration and Carbonate System Alkalinity in Anaerobic Digesters, Agricultural Engineering International: the CIGR Ejournal, IX, 2007.

Hafner, S. D., Montes, F. and Alan Rotz, C.: The role of carbon dioxide in emission of ammonia from manure, Atmospheric Environment, 66, 63-71, doi:10.1016/j.atmosenv.2012.01.026, 2012.

Hafner, S. D., Sommer, S. G., Petersen, V. and Markfoged, R.: Effects of carbon dioxide hydration kinetics and evaporative convection on $\mathrm{pH}$ profile development during interfacial mass transfer of ammonia and carbon dioxide, Heat Mass Transfer, 1-8, doi:10.1007/s00231-016-1910-6, 2016.

Parkhurst, D.L., and Appelo, C.A.J.,: Description of input and examples for PHREEQC version 3--A computer program for speciation, batch- reaction, one-dimensional transport, and inverse geochemical calculations: U.S. Geological Survey Techniques and Methods, book 6, chap. A43, 497 p., available at http://pubs.usgs.gov/tm/06/a43, 2013.

Charlton, S.R., and Parkhurst, D.L.: Modules based on the geochemical model PHREEQC for use in scripting and programming languages: Computers \& Geosciences, v. 37, p. 1653-1663, 2011. 
Bijlage 3: Grondstoffen- en nutriëntensamenstelling vleesvarkensvoeders

1. startvoer

\begin{tabular}{|c|c|c|c|c|c|}
\hline Startvoer & & controle & verlaagd eiwit & verzurend & $\begin{array}{l}\text { verlaagd eiwit + } \\
\text { verzurend }\end{array}$ \\
\hline & & Start 1 & Start 2 & Start 3 & Start 4 \\
\hline MAIS & $\%$ & 11,32 & 12,81 & 11,79 & 12,81 \\
\hline GERST & $\%$ & 24,63 & 24,63 & 24,63 & 24,63 \\
\hline TARWE & $\%$ & 17,50 & 16,75 & 14,78 & 16,75 \\
\hline MAISVOERMEEL & $\%$ & 5,00 & 4,81 & 5,00 & 4,41 \\
\hline TARWEGRIES & $\%$ & & 3,39 & 1,01 & 4,21 \\
\hline KOEKMIX & $\%$ & 4,93 & 4,38 & 4,93 & 3,94 \\
\hline TARWEGLUTENVRML & $\%$ & 7,30 & 6,90 & 7,22 & 6,90 \\
\hline PLANTVET & $\%$ & 1,61 & 1,92 & 1,82 & 1,90 \\
\hline AARDAPPELEIWIT & $\%$ & & 0,28 & & \\
\hline SOYA HIPRO & $\%$ & 17,29 & 14,87 & 17,77 & 16,04 \\
\hline SOYAHULLEN & $\%$ & & 1,04 & & 0,77 \\
\hline RAAPSCHROOT & $\%$ & 4,93 & & 4,93 & \\
\hline ZONNEBLOEMSCHROOT & $\%$ & 1,48 & 0,99 & 1,21 & \\
\hline WEICONCENTRAAT & $\%$ & 0,40 & 3,00 & 0,10 & 2,07 \\
\hline KRIJT & $\%$ & 1,14 & 1,11 & 0,30 & 0,30 \\
\hline ZOUT & $\%$ & 0,28 & 0,20 & 0,29 & 0,21 \\
\hline PREMIX & $\%$ & 0,25 & 0,25 & 0,25 & 0,25 \\
\hline METHIONINE & $\%$ & 0,09 & 0,17 & 0,10 & 0,21 \\
\hline LYSINE & $\%$ & 0,52 & 0,71 & 0,50 & 0,70 \\
\hline THREONINE & $\%$ & 0,14 & 0,22 & 0,14 & 0,22 \\
\hline TRYPTOFAAN & $\%$ & 0,05 & 0,17 & 0,05 & 0,16 \\
\hline VALINE & $\%$ & & 0,29 & & 0,30 \\
\hline BENZOEZUUR & $\%$ & & & 1,00 & 1,00 \\
\hline CA-FORMIAAT & $\%$ & & & 1,04 & 1,03 \\
\hline
\end{tabular}

\section{Berekende samenstelling}

\begin{tabular}{|l|l|c|c|c|c|}
\hline Ruw eiwit & $\%$ & 18,50 & 16,50 & 18,50 & 16,50 \\
\hline Ruw vet extr & $\%$ & 4,37 & 4,63 & 4,59 & 4,57 \\
\hline Ruwe celstof & $\%$ & 4,20 & 4,04 & 4,20 & 3,84 \\
\hline Ruw as & $\%$ & 5,00 & 4,95 & 4,99 & 4,92 \\
\hline Vocht & $\%$ & 10,67 & 11,69 & 10,44 & 11,31 \\
\hline Zetmeel Ew & $\%$ & 39,48 & 40,12 & 38,40 & 39,93 \\
\hline Suikers & $\%$ & 5,33 & 5,55 & 5,27 & 5,31 \\
\hline VooS & $\%$ & 9,08 & 8,80 & 9,10 & 8,70 \\
\hline OOOS & $\%$ & 16,42 & 16,13 & 16,66 & 16,08 \\
\hline EW(x100) & - & 114 & 114 & 114 & 114 \\
\hline il-lys Va AID & $\%$ & 1,02 & 1,02 & 1,02 & 1,02 \\
\hline il-meth Va AID & $\%$ & 0,34 & 0,39 & 0,35 & 0,42 \\
\hline il-m+c Va AID & $\%$ & 0,60 & 0,61 & 0,60 & 0,64 \\
\hline il-treo Va AID & $\%$ & 0,66 & 0,66 & 0,66 & 0,66 \\
\hline il-tryp Va AID & $\%$ & 0,19 & 0,19 & 0,19 & 0,19 \\
\hline il-isol Va AID & $\%$ & 0,61 & 0,53 & 0,61 & 0,53 \\
\hline il-val Va AID & $\%$ & 0,70 & 0,64 & 0,70 & 0,64 \\
\hline
\end{tabular}




\begin{tabular}{|c|c|c|c|c|c|}
\hline Calcium & $\%$ & 0,70 & 0,70 & 0,70 & 0,70 \\
\hline P.totaal & $\%$ & 0,43 & 0,41 & 0,43 & 0,40 \\
\hline Kalium & $\%$ & 0,85 & 0,86 & 0,85 & 0,84 \\
\hline Natrium & $\%$ & 0,17 & 0,17 & 0,17 & 0,17 \\
\hline P.vertb & $\%$ & 0,27 & 0,28 & 0,27 & 0,27 \\
\hline$S$ totaal & $\%$ & 0,27 & 0,28 & 0,27 & 0,28 \\
\hline dEB & meq & 215 & 220 & 215 & 220 \\
\hline Vit A -added & $\mathrm{IE} / \mathrm{kg}$ & 10000 & 10000 & 10000 & 10000 \\
\hline Vit D3 -added & $\mathrm{IE} / \mathrm{kg}$ & 2000 & 2000 & 2000 & 2000 \\
\hline Vit E -added & $\mathrm{mg} / \mathrm{kg}$ & 120 & 120 & 120 & 120 \\
\hline Fytase-equiv & $\mathrm{FU} / \mathrm{kg}$ & 1000 & 1000 & 1000 & 1000 \\
\hline \multicolumn{6}{|c|}{ Berekende vert. coëfficiënten m.b.v. de Veevoedertabel } \\
\hline Vert. coëff. ruw eiwit & $\mathrm{kg} / \mathrm{kg}$ & 0,83 & 0,84 & 0,83 & 0,84 \\
\hline Vert. coëff. ruw vet & $\mathrm{kg} / \mathrm{kg}$ & 0,72 & 0,72 & 0,72 & 0,72 \\
\hline $\begin{array}{l}\text { Vert. coëff. ruwe celstof } \\
\text { Vert. coëff. overige }\end{array}$ & $\mathrm{kg} / \mathrm{kg}$ & 0,40 & 0,41 & 0,40 & 0,41 \\
\hline koolhydraten & $\mathrm{kg} / \mathrm{kg}$ & 0,90 & 0,91 & 0,90 & 0,92 \\
\hline
\end{tabular}




\section{Tussenvoer}

\begin{tabular}{|c|c|c|c|c|c|}
\hline Tussenvoer & & controle & verlaagd eiwit & verzurend & $\begin{array}{c}\text { verlaagd eiwit } \\
+ \text { verzurend }\end{array}$ \\
\hline & & Tussen 1 & Tussen 2 & Tussen 3 & Tussen 4 \\
\hline MAIS & $\%$ & 5,40 & 5,00 & 5,00 & 5,00 \\
\hline GERST & $\%$ & 19,80 & 22,70 & 19,80 & 22,00 \\
\hline TARWE & $\%$ & 27,45 & 26,80 & 25,07 & 24,80 \\
\hline MAISVOERMEEL & $\%$ & 4,50 & 4,95 & 4,75 & 4,95 \\
\hline TARWEGRIES & $\%$ & 7,00 & 9,90 & 7,00 & 9,90 \\
\hline KOEKMIX & $\%$ & 4,30 & 4,00 & 5,00 & 5,00 \\
\hline TARWEGLUTENVOERML & $\%$ & 5,00 & 5,00 & 5,00 & 5,00 \\
\hline PLANTVET & $\%$ & 1,50 & 1,60 & 1,95 & 2,00 \\
\hline BIETENPULP & $\%$ & 1,10 & 1,30 & 1,10 & 1,30 \\
\hline SOYA HIPRO & $\%$ & 10,10 & 7,90 & 11,00 & 8,30 \\
\hline SOYAHULLEN & $\%$ & 1,30 & 2,00 & 1,30 & 2,00 \\
\hline RAAPSCHROOT & $\%$ & 5,00 & & 5,00 & \\
\hline 29-ZONNEPITSCHROOT & $\%$ & 4,00 & 2,90 & 3,20 & 3,00 \\
\hline PALMPITSCHILFERS & $\%$ & & & & \\
\hline WEICONCENTRAAT & $\%$ & 1,10 & 3,00 & 1,10 & 2,80 \\
\hline KRIJT & $\%$ & 0,89 & 0,89 & & \\
\hline ZOUT & $\%$ & 0,20 & 0,22 & 0,20 & 0,12 \\
\hline VITEXTRA & $\%$ & 0,19 & 0,19 & 0,19 & 0,19 \\
\hline VLEESV.PREMIX & $\%$ & 0,26 & 0,26 & 0,26 & 0,26 \\
\hline METHIONINE & $\%$ & 0,03 & 0,08 & 0,03 & 0,08 \\
\hline LYSINE & $\%$ & 0,41 & 0,61 & 0,38 & 0,60 \\
\hline THREONINE & $\%$ & 0,09 & 0,17 & 0,09 & 0,17 \\
\hline TRYPTOFAAN & $\%$ & & 0,09 & & 0,08 \\
\hline BENZOEZUUR & $\%$ & & & 1,00 & 1,00 \\
\hline CA-FORMIAAT & $\%$ & & & 1,00 & 1,00 \\
\hline
\end{tabular}

\section{Berekende samenstelling}

\begin{tabular}{|l|ll|c|c|c|}
\hline Ruw eiwit & $\%$ & 16,03 & 14,00 & 16,03 & 14,02 \\
\hline Ruw vet extr & $\%$ & 4,21 & 4,24 & 4,70 & 4,71 \\
\hline Ruwe celstof & $\%$ & 5,85 & 5,48 & 5,64 & 5,49 \\
\hline Ruw as & $\%$ & 4,81 & 4,75 & 4,70 & 4,54 \\
\hline Vocht & $\%$ & 11,53 & 12,27 & 11,28 & 11,94 \\
\hline Zetmeel Ew & $\%$ & 39,01 & 40,46 & 37,89 & 39,32 \\
\hline Suikers & $\%$ & 5,00 & 5,08 & 5,09 & 5,12 \\
\hline voOS & $\%$ & 10,30 & 9,92 & 10,29 & 9,92 \\
\hline OOS & $\%$ & 19,54 & 19,06 & 19,48 & 19,24 \\
\hline EW(x100) & - & 109,4 & 109,4 & 109,6 & 109,5 \\
\hline AID-lys & $\%$ & 0,79 & 0,79 & 0,79 & 0,79 \\
\hline AID-meth & $\%$ & 0,25 & 0,26 & 0,25 & 0,26 \\
\hline AID-m+c & $\%$ & 0,48 & 0,46 & 0,48 & 0,46 \\
\hline AID-treo & $\%$ & 0,51 & 0,51 & 0,52 & 0,52 \\
\hline AID-tryp & $\%$ & 0,15 & 0,15 & 0,15 & 0,15 \\
\hline AID-isol & $\%$ & 0,50 & 0,41 & 0,50 & 0,42 \\
\hline AID-val & $\%$ & 0,59 & 0,50 & 0,59 & 0,50 \\
\hline
\end{tabular}




\begin{tabular}{|c|c|c|c|c|c|}
\hline Calcium & $\%$ & 0,65 & 0,65 & 0,62 & 0,62 \\
\hline P.totaal & $\%$ & 0,47 & 0,44 & 0,47 & 0,44 \\
\hline Kalium & $\%$ & 0,80 & 0,78 & 0,80 & 0,78 \\
\hline Natrium & $\%$ & 0,14 & 0,18 & 0,14 & 0,14 \\
\hline P.vertb & $\%$ & 0,27 & 0,27 & 0,27 & 0,27 \\
\hline $\mathrm{S}$ total & $\%$ & 0,24 & 0,23 & 0,23 & 0,23 \\
\hline dEB & meq & 198 & 200 & 199 & 201 \\
\hline Vit A -added & $\mathrm{IE} / \mathrm{kg}$ & 9719 & 9719 & 9719 & 9719 \\
\hline Vit D3 -added & $\mathrm{IE} / \mathrm{kg}$ & 1996 & 1996 & 1996 & 1996 \\
\hline Vit E -added & $\mathrm{mg} / \mathrm{kg}$ & 101 & 101 & 101 & 101 \\
\hline Fytase-equiv & $\mathrm{FU} / \mathrm{kg}$ & 758 & 758 & 758 & 758 \\
\hline \multicolumn{6}{|c|}{ Berekende vert. coëfficiënten m.b.v. de Veevoedertabel } \\
\hline Vert. coëff. ruw eiwit & $\mathrm{kg} / \mathrm{kg}$ & 0,80 & 0,81 & 0,80 & 0,81 \\
\hline Vert. coëff. ruw vet & $\mathrm{kg} / \mathrm{kg}$ & 0,70 & 0,70 & 0,71 & 0,71 \\
\hline Vert. coëff. ruwe celstof & $\mathrm{kg} / \mathrm{kg}$ & 0,35 & 0,36 & 0,36 & 0,36 \\
\hline Vert. coëff. overige & & & & & \\
\hline koolhydraten & $\mathrm{kg} / \mathrm{kg}$ & 0,85 & 0,87 & 0,86 & 0,87 \\
\hline
\end{tabular}




\section{Eindvoer}

\begin{tabular}{|c|c|c|c|c|c|}
\hline Eindvoer & & controle & verlaagd eiwit & verzurend & $\begin{array}{c}\text { verlaagd eiwit } \\
\text { + verzurend }\end{array}$ \\
\hline & & Eind 1 & Eind 2 & Eind 3 & Eind 4 \\
\hline MAIS & $\%$ & 5,00 & 5,00 & 5,40 & 5,00 \\
\hline GERST & $\%$ & 19,80 & 19,80 & 19,80 & 19,80 \\
\hline TARWE & $\%$ & 27,65 & 29,64 & 24,56 & 28,74 \\
\hline MAISVOERMEEL & $\%$ & 4,50 & 4,95 & 4,50 & 4,95 \\
\hline TARWEGRIES & $\%$ & 7,00 & 10,00 & 7,00 & 10,00 \\
\hline KOEKMIX & $\%$ & 3,50 & 2,80 & 4,50 & 3,00 \\
\hline TARWEGLUTENVOERML & $\%$ & 4,50 & 4,50 & 4,50 & 4,90 \\
\hline PLANTVET & $\%$ & 1,00 & 1,00 & 1,40 & 1,35 \\
\hline BIETENPULP & $\%$ & 1,10 & 1,50 & 1,10 & 1,20 \\
\hline SOYA HIPRO & $\%$ & 8,50 & 5,00 & 9,00 & 5,00 \\
\hline SOYAHULLEN & $\%$ & 1,00 & 1,00 & 1,00 & 1,00 \\
\hline RAAPSCHROOT & $\%$ & 4,80 & 1,00 & 5,00 & 1,10 \\
\hline 29-ZONNEPITSCHROOT & $\%$ & 3,50 & 3,50 & 3,50 & 3,60 \\
\hline PALMPITSCHILFERS & $\%$ & 4,40 & 4,90 & 3,80 & 5,00 \\
\hline WEICONCENTRAAT & $\%$ & 1,70 & 3,00 & 1,70 & 1,70 \\
\hline KRIJT & $\%$ & 0,93 & 0,96 & 0,13 & 0,18 \\
\hline ZOUT & $\%$ & 0,19 & 0,09 & 0,19 & 0,08 \\
\hline VITEXTRA & $\%$ & & & & \\
\hline VLEESV.PREMIX & $\%$ & 0,25 & 0,25 & 0,25 & 0,25 \\
\hline METHIONINE & $\%$ & & 0,03 & & \\
\hline LYSINE & $\%$ & 0,29 & 0,51 & 0,28 & 0,51 \\
\hline THREONINE & $\%$ & 0,04 & 0,12 & 0,04 & 0,12 \\
\hline TRYPTOFAAN & $\%$ & & & & \\
\hline BENZOEZUUR & $\%$ & & & 1,00 & 1,00 \\
\hline CA-FORMIAAT & $\%$ & & & 1,00 & 1,00 \\
\hline
\end{tabular}

\section{Berekende samenstelling}

\begin{tabular}{|l|ll|c|c|c|}
\hline Ruw eiwit & $\%$ & 15,52 & 13,52 & 15,52 & 13,50 \\
\hline Ruw vet extr & $\%$ & 3,86 & 3,82 & 4,29 & 4,20 \\
\hline Ruwe celstof & $\%$ & 6,21 & 6,05 & 6,13 & 6,08 \\
\hline Ruw as & $\%$ & 4,69 & 4,50 & 4,68 & 4,44 \\
\hline Vocht & $\%$ & 11,68 & 12,23 & 11,42 & 11,52 \\
\hline Zetmeel Ew & $\%$ & 38,33 & 39,94 & 37,17 & 39,55 \\
\hline Suikers & $\%$ & 4,89 & 4,77 & 5,01 & 4,37 \\
\hline Voos & $\%$ & 11,51 & 11,17 & 11,32 & 11,05 \\
\hline OOS & $\%$ & 21,16 & 21,03 & 21,06 & 21,20 \\
\hline EW(x100) & - & 107,2 & 107,3 & 107,2 & 107,2 \\
\hline AID-lys & $\%$ & 0,68 & 0,68 & 0,68 & 0,68 \\
\hline AID-meth & $\%$ & 0,21 & 0,21 & 0,21 & 0,21 \\
\hline AID-m+c & $\%$ & 0,44 & 0,41 & 0,44 & 0,41 \\
\hline AID-treo & $\%$ & 0,44 & 0,44 & 0,45 & 0,44 \\
\hline AID-tryp & $\%$ & 0,14 & 0,13 & 0,14 & 0,13 \\
\hline AID-isol & $\%$ & 0,47 & 0,38 & 0,47 & 0,38 \\
\hline AID-val & $\%$ & 0,56 & 0,47 & 0,57 & 0,47 \\
\hline Calcium & $\%$ & 0,62 & 0,61 & 0,62 & 0,61 \\
\hline
\end{tabular}




\begin{tabular}{|c|c|c|c|c|c|}
\hline P.totaal & $\%$ & 0,47 & 0,45 & 0,47 & 0,45 \\
\hline Kalium & $\%$ & 0,78 & 0,74 & 0,79 & 0,74 \\
\hline Natrium & $\%$ & 0,14 & 0,14 & 0,14 & 0,14 \\
\hline P.vertb & $\%$ & 0,25 & 0,26 & 0,26 & 0,25 \\
\hline $\mathrm{S}$ total & $\%$ & 0,22 & 0,21 & 0,22 & 0,21 \\
\hline $\mathrm{dEB}$ & meq & 193 & 195 & 194 & 195 \\
\hline Vit A -added & $\mathrm{IE} / \mathrm{kg}$ & 7758 & 7758 & 7758 & 7758 \\
\hline Vit D3 -added & $\mathrm{IE} / \mathrm{kg}$ & 1842 & 1842 & 1842 & 1842 \\
\hline Vit E -added & $\mathrm{mg} / \mathrm{kg}$ & 99 & 99 & 99 & 99 \\
\hline Fytase-equiv & $\mathrm{FU} / \mathrm{kg}$ & 657 & 657 & 657 & 657 \\
\hline \multicolumn{6}{|c|}{ Berekende vert. coëfficiënten m.b.v. de Veevoedertabel } \\
\hline Vert. coëff. ruw eiwit & $\mathrm{kg} / \mathrm{kg}$ & 0,78 & 0,77 & 0,78 & 0,77 \\
\hline Vert. coëff. ruw vet & $\mathrm{kg} / \mathrm{kg}$ & 0,70 & 0,70 & 0,71 & 0,71 \\
\hline $\begin{array}{l}\text { Vert. coëff. ruwe celstof } \\
\text { Vert. coëff. overige }\end{array}$ & $\mathrm{kg} / \mathrm{kg}$ & 0,34 & 0,32 & 0,34 & 0,32 \\
\hline koolhydraten & $\mathrm{kg} / \mathrm{kg}$ & 0,86 & 0,86 & 0,86 & 0,85 \\
\hline
\end{tabular}




\begin{tabular}{|c|c|c|c|c|c|c|c|c|c|c|c|c|c|c|}
\hline Productnaam & Behandeling & $\begin{array}{l}\text { re } \\
(\mathrm{g} / \mathrm{kg})\end{array}$ & $\begin{array}{l}\text { rvet } \\
(\mathrm{g} / \mathrm{kg})\end{array}$ & $\begin{array}{l}\mathrm{rc} \\
(\mathrm{g} / \mathrm{kg})\end{array}$ & $\begin{array}{l}\text { ras } \\
(\mathrm{g} / \mathrm{kg})\end{array}$ & $\begin{array}{l}\text { suiker } \\
(\mathrm{g} / \mathrm{kg})\end{array}$ & $\begin{array}{l}\text { zetmeel } \\
(\mathrm{g} / \mathrm{kg})\end{array}$ & $\begin{array}{l}\mathrm{Ca} \\
(\mathrm{g} / \mathrm{kg})\end{array}$ & $\begin{array}{l}\mathrm{K} \\
(\mathrm{g} / \mathrm{kg})\end{array}$ & $\begin{array}{l}\mathrm{Na} \\
(\mathrm{g} / \mathrm{kg})\end{array}$ & $\begin{array}{l}\mathrm{Cl} \\
(\mathrm{g} / \mathrm{kg})\end{array}$ & $\begin{array}{l}\text { Sulfaat } \\
(\mathrm{mg} / \mathrm{kg})\end{array}$ & $\begin{array}{l}\text { Benzoëzuur } \\
(\mathrm{mg} / \mathrm{kg})\end{array}$ & $\begin{array}{l}\text { Mierenzuur } \\
(\mathrm{mg} / \mathrm{kg})\end{array}$ \\
\hline Startvoer 1 & Controle & 186 & 50 & 42 & 51 & 54 & 357 & 8,42 & 8,12 & 1,45 & 2,5 & 2180 & & \\
\hline Startvoer 2 & Verlaagd eiwit & 162 & 49 & 42 & 57 & 49 & 368 & 11,7 & 8,27 & 1,44 & 2,5 & 2630 & & \\
\hline Startvoer 3 & Verzurend & 179 & 53 & 43 & 50 & 52 & 359 & 7,63 & 8,36 & 1,68 & 2,7 & 2370 & 8700 & 5260 \\
\hline Startvoer 4 & Verlaagd eiwit / verzurend & 168 & 54 & 39 & 49 & 60 & 362 & 7,65 & 8,33 & 1,64 & 2,8 & 2580 & 6500 & 6380 \\
\hline Tussenvoer 1 & Controle & 162 & 44 & 55 & 48 & 51 & 368 & 7,36 & 7,9 & 1,36 & 2,3 & 1880 & & \\
\hline Tussenvoer 2 & Verlaagd eiwit & 151 & 43 & 52 & 49 & 51 & 387 & 7,2 & 7,5 & 1,52 & 2,7 & 2250 & & \\
\hline Tussenvoer 3 & Verzurend & 157 & 44 & 52 & 46 & 56 & 382 & 7,02 & 7,63 & 1,32 & 2,3 & 1720 & 7010 & 4780 \\
\hline Tussenvoer 4 & Verlaagd eiwit / verzurend & 144 & 47 & 57 & 47 & 50 & 364 & 7,94 & 7,62 & 1,3 & 2,2 & 2320 & 8820 & 6030 \\
\hline Afmestvoer 1 & Controle & 156 & 41 & 57 & 46 & 51 & 375 & 6,75 & 7,62 & 1,27 & 2,3 & 1730 & & \\
\hline Afmestvoer 2 & Verlaagd eiwit & 137 & 41 & 57 & 44 & 44 & 400 & 6,44 & 7,18 & 1,32 & 2,1 & 2210 & & \\
\hline Afmestvoer 3 & Verzurend & 156 & 44 & 58 & 46 & 50 & 372 & 6,77 & 7,82 & 1,41 & 2,4 & 1740 & 8270 & 5840 \\
\hline Afmestvoer 4 & Verlaagd eiwit / verz & 136 & 44 & 62 & 39 & 44 & 375 & 7,61 & 7,01 & 1,26 & 1,6 & 2160 & 9370 & 6150 \\
\hline
\end{tabular}


Bijlage 4: Grondstoffen- en nutriëntensamenstelling biggenvoeders

\begin{tabular}{|c|c|c|c|c|c|c|c|c|}
\hline Componenten & $\begin{array}{r}\text { speen } 1 \\
\mathbf{g} / \mathbf{k g}\end{array}$ & $\begin{array}{r}\text { speen } 2 \\
\mathbf{g} / \mathbf{k g}\end{array}$ & $\begin{array}{r}\text { speen } 3 \\
\mathbf{g} / \mathbf{k g}\end{array}$ & $\begin{array}{r}\text { speen } 4 \\
\mathrm{~g} / \mathbf{k g}\end{array}$ & $\begin{array}{r}\text { opfok } 1 \\
\mathbf{g} / \mathbf{k g}\end{array}$ & $\begin{array}{r}\text { opfok } 2 \\
\mathbf{g} / \mathbf{k g}\end{array}$ & $\begin{array}{r}\text { opfok } 3 \\
\mathbf{g} / \mathbf{k g}\end{array}$ & $\begin{array}{r}\text { opfok } 4 \\
\mathrm{~g} / \mathbf{k g}\end{array}$ \\
\hline Tarwe & 300,0 & 300,0 & 300,0 & 300,0 & 220,0 & 220,0 & 220,0 & 220,0 \\
\hline Gerst & 250,0 & 250,0 & 250,0 & 250,0 & 300,0 & 300,0 & 300,0 & 300,0 \\
\hline Mais & 62,5 & 62,5 & 79,0 & 79,0 & 130,0 & 130,0 & 142,0 & 142,0 \\
\hline $\begin{array}{l}\text { Sojaschroot, } R C<45 \\
R E<480\end{array}$ & 47,9 & 57,2 & 50,8 & 66,1 & 75,0 & 58,5 & 77,4 & 56,9 \\
\hline Sojaconcentraat & 40,0 & 40,0 & 40,0 & 40,0 & 30,0 & 30,0 & 30,0 & 30,0 \\
\hline Aardappeleiwit & 30,0 & 30,0 & 30,0 & 30,0 & 30,0 & 30,0 & 30,0 & 30,0 \\
\hline Wei Vetkern & 20,0 & 20,0 & 20,0 & 20,0 & 20,0 & 20,0 & 20,0 & 20,0 \\
\hline Maïsglutenmeel & 50,0 & 9,8 & 50,0 & 6,7 & 35,4 & 8,9 & 35,0 & 11,1 \\
\hline Tarwegries & 50,0 & 38,8 & 41,4 & 24,1 & 21,0 & 30,7 & 19,6 & 30,7 \\
\hline Bietpulp SUI $<100$ & 14,5 & 19,0 & 0,0 & 6,6 & 17,4 & 17,2 & 0,0 & 0,0 \\
\hline Lactose & 20,0 & 20,0 & 20,0 & 20,0 & 20,0 & 20,0 & 20,0 & 20,0 \\
\hline Kristalsuiker & 20,0 & 20,0 & 20,0 & 20,0 & 20,0 & 20,0 & 20,0 & 20,0 \\
\hline Natief maiszetmeel & 0,0 & 37,6 & 0,0 & 39,4 & 0,0 & 29,2 & 0,0 & 30,3 \\
\hline Melasseriet SUI $<475$ & 20,0 & 20,0 & 20,0 & 20,0 & 20,0 & 20,0 & 20,0 & 20,0 \\
\hline Sojaolie & 24,7 & 22,6 & 20,4 & 17,9 & 13,2 & 12,9 & 10,0 & 9,3 \\
\hline Krijt (fijn gemalen) & 12,1 & 11,8 & 0,0 & 0,0 & 11,6 & 12,5 & 0,0 & 0,0 \\
\hline Calcium-formiaat & 0,0 & 0,0 & 15,1 & 14,8 & 0,0 & 0,0 & 14,6 & 14,6 \\
\hline Mono-Calcium fosfaat & 8,5 & 8,6 & 8,5 & 8,7 & 8,2 & 8,4 & 8,2 & 8,4 \\
\hline Landbouwzout & 2,7 & 2,7 & 2,6 & 2,7 & 3,0 & 2,3 & 3,0 & 2,2 \\
\hline Natriumbicarbonaat & 4,1 & 4,1 & 4,2 & 4,0 & 3,7 & 4,6 & 3,7 & 4,9 \\
\hline Premix & 5,0 & 5,0 & 5,0 & 5,0 & 5,0 & 5,0 & 5,0 & 5,0 \\
\hline Melkzuur & 10,0 & 10,0 & 10,0 & 10,0 & 10,0 & 10,0 & 10,0 & 10,0 \\
\hline Benzoëzuur & 0,0 & 0,0 & 5,0 & 5,0 & 0,0 & 0,0 & 5,0 & 5,0 \\
\hline L-Lysine $\mathrm{HCl}$ & 5,3 & 5,5 & 5,3 & 5,4 & 4,4 & 5,2 & 4,4 & 5,3 \\
\hline DL-Methionine & 1,0 & 1,9 & 1,0 & 1,9 & 0,9 & 1,7 & 0,9 & 1,6 \\
\hline L-Threonine & 1,1 & 1,7 & 1,1 & 1,7 & 0,8 & 1,6 & 0,8 & 1,5 \\
\hline L-Tryptofaan & 0,6 & 0,7 & 0,6 & 0,6 & 0,4 & 0,6 & 0,4 & 0,5 \\
\hline L-Valine & 0,0 & 0,0 & 0,0 & 0,0 & 0,0 & 0,7 & 0,0 & 0,7 \\
\hline L-Isoleucine & 0,0 & 0,5 & 0,0 & 0,4 & 0,0 & 0,0 & 0,0 & 0,0 \\
\hline \multicolumn{9}{|c|}{ Berekende samenstelling } \\
\hline DS & 885,4 & 884,7 & 885,3 & 884,4 & 883,2 & 883,0 & 883,0 & 882,7 \\
\hline RAS & 55,2 & 55,0 & 51,6 & 51,5 & 54,5 & 55,1 & 51,1 & 50,8 \\
\hline $\mathrm{RE}$ & 180,0 & 160,0 & 180,0 & 160,0 & 175,0 & 155,0 & 175,0 & 155,0 \\
\hline RVETh & 50,6 & 46,1 & 46,7 & 41,5 & 40,4 & 38,6 & 37,6 & 35,4 \\
\hline $\mathrm{RC}$ & 30,8 & 30,6 & 27,9 & 27,8 & 31,2 & 31,2 & 28,3 & 28,3 \\
\hline ZETam & 348,1 & 370,6 & 356,6 & 379,1 & 361,9 & 383,1 & 368,8 & 391,6 \\
\hline SUI & 91,2 & 91,8 & 90,1 & 91,2 & 91,6 & 90,4 & 90,7 & 89,1 \\
\hline NSP & 160,0 & 160,0 & 160,0 & 160,0 & 160,0 & 160,0 & 160,0 & 160,0 \\
\hline VNSPV & 94,4 & 95,3 & 94,2 & 96,2 & 97,1 & 94,3 & 95,8 & 92,7 \\
\hline EW & 1,12 & 1,12 & 1,12 & 1,12 & 1,10 & 1,10 & 1,10 & 1,10 \\
\hline $\mathrm{Ca}$ & 7,0 & 7,0 & 7,0 & 7,0 & 6,8 & 7,2 & 6,8 & 6,8 \\
\hline$P$ & 5,3 & 5,1 & 5,2 & 5,0 & 5,1 & 5,0 & 5,1 & 5,0 \\
\hline VP & 3,5 & 3,5 & 3,5 & 3,5 & 3,4 & 3,4 & 3,4 & 3,4 \\
\hline $\mathrm{K}$ & 6,5 & 6,5 & 6,5 & 6,5 & 6,7 & 6,4 & 6,7 & 6,4 \\
\hline $\mathrm{Na}$ & 2,4 & 2,4 & 2,4 & 2,4 & 2,4 & 2,4 & 2,4 & 2,4 \\
\hline $\mathrm{Cl}$ & 3,9 & 3,9 & 3,9 & 3,9 & 3,9 & 3,7 & 3,9 & 3,6 \\
\hline $\mathrm{dEB}(\mathrm{mEq} / \mathrm{kg})$ & 161 & 161 & 161 & 161 & 165 & 165 & 165 & 165 \\
\hline schDVLYSv & 10,5 & 10,5 & 10,5 & 10,5 & 10,0 & 10,0 & 10,0 & 10,0 \\
\hline schDVMETv & 3,8 & 4,1 & 3,8 & 4,1 & 3,6 & 3,9 & 3,5 & 3,9 \\
\hline schDVM+CV & 6,3 & 6,3 & 6,3 & 6,3 & 6,0 & 6,0 & 6,0 & 6,0 \\
\hline schDVTHRv & 6,2 & 6,2 & 6,2 & 6,2 & 5,9 & 5,9 & 5,9 & 5,9 \\
\hline schDVTRPV & 2,1 & 2,1 & 2,1 & 2,1 & 1,9 & 1,9 & 1,9 & 1,9 \\
\hline schDVILEv & 6,0 & 5,8 & 6,1 & 5,8 & 5,9 & 5,1 & 6,0 & 5,1 \\
\hline schDVVALv & 6,9 & 6,1 & 7,0 & 6,1 & 6,8 & 6,6 & 6,9 & 6,6 \\
\hline
\end{tabular}




\begin{tabular}{|c|c|c|c|c|c|c|c|c|}
\hline & speen 1 & speen 2 & speen 3 & speen 4 & opfok 1 & opfok 2 & opfok 3 & opfok 4 \\
\hline Vert. coëff. ruw eiwit & 0,85 & 0,84 & 0,85 & 0,84 & 0,84 & 0,83 & 0,85 & 0,84 \\
\hline Vert. coëff. ruw vet & 0,79 & 0,79 & 0,78 & 0,77 & 0,75 & 0,75 & 0,74 & 0,73 \\
\hline $\begin{array}{l}\text { Vert. coëff. ruwe } \\
\text { celstof }\end{array}$ & 0,30 & 0,31 & 0,26 & 0,29 & 0,33 & 0,31 & 0,29 & 0,27 \\
\hline $\begin{array}{l}\text { Vert. coëff. overige } \\
\text { koolhydraten }\end{array}$ & 0,91 & 0,92 & 0,92 & 0,92 & 0,92 & 0,92 & 0,92 & 0,92 \\
\hline
\end{tabular}




\begin{tabular}{|c|c|c|c|c|c|c|c|c|c|c|c|c|c|c|c|}
\hline Productnaam & Behandeling & Ronde & $\begin{array}{l}\text { re } \\
(\mathrm{g} / \mathrm{kg})\end{array}$ & $\begin{array}{l}\text { rvet } \\
(\mathrm{g} / \mathrm{kg})\end{array}$ & $\begin{array}{l}\mathrm{rc} \\
(\mathrm{g} / \mathrm{kg})\end{array}$ & $\begin{array}{l}\text { ras } \\
(\mathrm{g} / \mathrm{kg})\end{array}$ & $\begin{array}{l}\text { suiker } \\
(\mathrm{g} / \mathrm{kg})\end{array}$ & $\begin{array}{l}\text { zetmeel } \\
(\mathrm{g} / \mathrm{kg})\end{array}$ & $\begin{array}{l}\mathrm{Ca} \\
(\mathrm{g} / \mathrm{kg})\end{array}$ & $\begin{array}{l}\mathrm{K} \\
(\mathrm{g} / \mathrm{kg})\end{array}$ & $\begin{array}{l}\mathrm{Na} \\
(\mathrm{g} / \mathrm{kg})\end{array}$ & $\begin{array}{l}\mathrm{Cl} \\
(\mathrm{g} / \mathrm{kg})\end{array}$ & $\begin{array}{l}\text { Sulfaat } \\
(\mathrm{mg} / \mathrm{kg})\end{array}$ & $\begin{array}{l}\text { Benzoëzuur } \\
(\mathrm{mg} / \mathrm{kg})\end{array}$ & $\begin{array}{l}\text { Mierenzuur } \\
(\mathrm{mg} / \mathrm{kg})\end{array}$ \\
\hline Speenkorrel 1 & Controle & 1 & 187 & 55 & 27 & 49 & 86 & 368 & 8.09 & 6.73 & 2.97 & 4.1 & 1570 & 0 & 0 \\
\hline Speenkorrel 2 & Verlaagd eiwit & 1 & 165 & 47 & 27 & 47 & 91 & 397 & 7.62 & 6.75 & 2.56 & 4.2 & 1600 & 0 & 0 \\
\hline Speenkorrel 3 & Verzurend & 1 & 186 & 50 & 24 & 46 & 95 & 373 & 7.66 & 6.49 & 2.6 & 4.2 & 1520 & 4630 & 10700 \\
\hline Speenkorrel 4 & Verlaagd eiwit / verzurend & 1 & 167 & 43 & 25 & 46 & 90 & 410 & 7.56 & 6.7 & 2.36 & 4.1 & 1420 & 4680 & 11200 \\
\hline Opfokvoer 1 & Controle & 1 & 176 & 42 & 25 & 47 & 92 & 384 & 7.71 & 6.87 & 2.54 & 4.2 & 1680 & 0 & 0 \\
\hline Opfokvoer 2 & Verlaagd eiwit & 1 & 159 & 39 & 26 & 47 & 88 & 410 & 8.18 & 6.54 & 2.64 & 3.9 & 1520 & 0 & 0 \\
\hline Opfokvoer 3 & Verzurend & 1 & 180 & 42 & 23 & 46 & 81 & 401 & 7.66 & 6.75 & 2.42 & 4 & 1490 & 4590 & 10800 \\
\hline Opfokvoer 4 & Verlaagd eiwit / verzurend & 1 & 161 & 37 & 23 & 45 & 81 & 419 & 7.59 & 6.4 & 2.5 & 3.9 & 1360 & 4640 & 9910 \\
\hline Speenkorrel 1 & Controle & 2 & 188 & 55 & 29 & 49 & 80 & 374 & 7.91 & 6.88 & 2.56 & 4.3 & 1520 & 0 & 0 \\
\hline Speenkorrel 2 & Verlaagd eiwit & 2 & 158 & 49 & 28 & 49 & 81 & 410 & 8.22 & 7.03 & 2.62 & 4.2 & 1320 & 0 & 0 \\
\hline Speenkorrel 3 & Verzurend & 2 & 183 & 48 & 25 & 48 & 82 & 390 & 7.68 & 6.94 & 2.43 & 4.2 & 1440 & 4560 & 9780 \\
\hline Speenkorrel 4 & Verlaagd eiwit / verzurend & 2 & 162 & 43 & 24 & 49 & 82 & 417 & 7.97 & 7.15 & 2.51 & 4.2 & 1260 & 4680 & 10100 \\
\hline Opfokvoer 1 & Controle & 2 & 182 & 42 & 28 & 47 & 83 & 389 & 7.63 & 6.87 & 2.47 & 4.3 & 1550 & 0 & 0 \\
\hline Opfokvoer 2 & Verlaagd eiwit & 2 & 158 & 40 & 28 & 47 & 84 & 417 & 8.07 & 6.63 & 2.5 & 3.9 & 1650 & 0 & 0 \\
\hline Opfokvoer 3 & Verzurend & 2 & 181 & 40 & 24 & 47 & 83 & 397 & 7.92 & 6.65 & 2.57 & 4.3 & 1530 & 4480 & 9380 \\
\hline Opfokvoer 4 & Verlaagd eiwit / verzurend & 2 & 162 & 36 & 23 & 46 & 85 & 427 & 7.86 & 6.51 & 2.53 & 3.9 & 1480 & 4570 & 9290 \\
\hline
\end{tabular}


Bijlage 5: Grondstoffen- en nutriëntensamenstelling zeugenvoeders

\begin{tabular}{|c|c|c|}
\hline Componenten & $\begin{array}{r}\text { controlevoer } \\
\mathrm{g} / \mathbf{k g}\end{array}$ & $\begin{array}{r}\text { proefvoer } \\
\mathbf{g} / \mathbf{k g}\end{array}$ \\
\hline Gerst & 285,6 & 251,2 \\
\hline Mais & 149,0 & 149,0 \\
\hline Tarwegries & 99,0 & 158,0 \\
\hline Sojaschroot, RC $<45$ RE $>480$ & 38,0 & 41,0 \\
\hline Sojahullen RC 320-360 & 142,0 & 138,0 \\
\hline Palmpitschilf $\mathrm{RC}>180$ & 99,0 & 0,0 \\
\hline Zonblosr RC $<160$ & 65,0 & 0,0 \\
\hline Bietpulp SUI < 100 & 50,0 & 188,0 \\
\hline Melasseriet SUI $<475$ & 20,0 & 20,0 \\
\hline Palmolie & 27,5 & 27,5 \\
\hline Krijt (fijn gemalen) & 8,4 & 0,0 \\
\hline Calcium-formiaat & 0,0 & 8,2 \\
\hline Mono-Calcium fosfaat & 3,0 & 2,8 \\
\hline Landbouwzout & 2,4 & 2,2 \\
\hline Natriumbicarbonaat & 3,3 & 3,5 \\
\hline Premix & 5,0 & 5,0 \\
\hline Natuphos & 0,1 & 0,2 \\
\hline L-Lysine & 1,4 & 2,0 \\
\hline MHA vloeibaar & 0,3 & 1,0 \\
\hline Threonine $40 \%$ & 1,0 & 2,5 \\
\hline Totaal & 1000,0 & 1000,0 \\
\hline \multicolumn{3}{|l|}{ Berekende samenstelling } \\
\hline DS & 886 & 885 \\
\hline RAS & 55 & 53 \\
\hline RE & 130 & 115 \\
\hline RVETh & 56 & 48 \\
\hline $\mathrm{RC}$ & 119 & 112 \\
\hline ZET ewers & 281 & 274 \\
\hline NSP & 340 & 349 \\
\hline VNSPV & 232 & 258 \\
\hline EW & 0,99 & 0,99 \\
\hline $\mathrm{Ca}$ & 7,0 & 7,0 \\
\hline$P$ & 4,7 & 4,0 \\
\hline vP & 2,4 & 2,4 \\
\hline K & 8,1 & 7,8 \\
\hline $\mathrm{Na}$ & 2,0 & 2,0 \\
\hline $\mathrm{Cl}$ & 2,7 & 2,4 \\
\hline EB & 220 & 220 \\
\hline schDVLYSv & 4,6 & 4,6 \\
\hline schDVM+CV & 3,4 & 3,2 \\
\hline schDVTHRv & 3,4 & 3,4 \\
\hline schDVTRPv & 1,0 & 0,9 \\
\hline schDVILEv & 3,4 & 2,8 \\
\hline schDVVALV & 4,3 & 3,6 \\
\hline \multicolumn{3}{|c|}{ Berekende vert. coëfficiënten m.b.v. de Veevoedertabel $(\mathrm{kg} / \mathrm{kg})$} \\
\hline Vert. coëff. ruw eiwit & 0,63 & 0,62 \\
\hline Vert. coëff. ruw vet & 0,76 & 0,73 \\
\hline Vert. coëff. ruwe celstof & 0,45 & 0,57 \\
\hline Vert. coëff. overige koolhydraten & 0,80 & 0,85 \\
\hline
\end{tabular}




\section{Geanalyseerde samenstelling zeugenvoeders ${ }^{\mathbf{1}}$ )}

Productnaam

Behandeling

Periode ${ }^{2)}$

Zeugenvoer 1

Controle $\quad 1 \mathrm{e}$ deel

Zeugenvoer 2

Proef

$(\mathrm{g} / \mathrm{kg})$

$(g / k g)$

rc $(\mathrm{g} / \mathrm{kg})$

suiker

130

60

zetmeel

$\mathrm{g} / \mathrm{kg})$

$\mathrm{Ca}$

K $\quad \mathrm{Na}$

$\mathrm{Na} \quad \mathrm{Cl}$

Sulfaat Mierenzuur

$\begin{array}{llll}117 & 55 & 112 & 51\end{array}$

42

$278 \quad 7,0$

$7,01-7,58 \quad(\mathrm{~g} / \mathrm{kg})$

$\begin{array}{rr}1,57 & 2,3\end{array}$

$(\mathrm{mg} / \mathrm{kg}) \quad(\mathrm{mg} / \mathrm{kg})$

Zeugenvoer 1

Controle

2e deel

129

$66 \quad 130$

Zeugenvoer 2

Proef

2e deel

120

$50 \quad 114$

52

7,31

7,47

$1,85 \quad 2,1$

1280

1520

0

1) gehalten aan respectievelijk: re=ruw eiwit; rvet=ruw vet; rc=ruwe celstof; ras=ruw as

2) Het voer is in 2 verschillende batches gemaakt

64

27 
Bijlage 6: Momenten van aflaten van de mest uit de mestkelders

\section{Vleesvarkens}

Datum

27-11-2014

18-12-2014

30-12-2014

2-1-2015

20-1-2015

23-1-2015

10-2-2015

13-2-2015

3-3-2015

6-3-2015

\section{Biggen}

Datum

18-3-2015

31-3-2015

3-4-2015

14-4-2015

17-4-2015

29-4-2015

$12-5-2015$

15-5-2015

26-5-2015

29-5-2015

\section{Zeugen}

Datum

22-1-2015

12-2-2015

24-2-2015

27-2-2015

$17-3-2015$

20-3-2015

7-4-2015

10-4-2015

28-4-2015

1-5-2015

\section{Afdeling Activiteit}

11,12 opleg varkens

9,10 opleg varkens

$9,10,11,12$ aflaten mest en volzetten met water

$9,10,11,12$ aflaten water/mest

$9,10,11,12$ aflaten mest en volzetten met water

$9,10,11,12$ aflaten water/mest

$9,10,11,12$ aflaten mest en volzetten met water

$9,10,11,12$ aflaten water/mest

$9,10,11,12$ aflaten mest en volzetten met water

$9,10,11,12$ aflaten water/mest

\section{Afdeling Activiteit}

B6, B7, B8, B9 opleg biggen

B6, B7, B8, B9 aflaten mest en volzetten met water

B6, B7, B8, B9 aflaten water/mest

B6, B7, B8, B9 aflaten mest en volzetten met water

B6, B7, B8, B9 aflaten water/mest

B6, B7, B8, B9 opleg biggen

B6, B7, B8, B9 aflaten mest en volzetten met water

$B 6, B 7, B 8, B 9$ aflaten water/mest

B6, B7, B8, B9 aflaten mest en volzetten met water

B6, B7, B8, B9 aflaten water/mest

\section{Afdeling Activiteit \\ D4B opleg zeugen \\ D4A opleg zeugen}

$D 4 A$ en $D 4 B$ aflaten mest en volzetten met water

$D 4 A$ en $D 4 B$ aflaten water/mest

$D 4 A$ en $D 4 B$ aflaten mest en volzetten met water

$D 4 A$ en $D 4 B$ aflaten water/mest

$D 4 A$ en $D 4 B$ aflaten mest en volzetten met water

D4A en D4B aflaten water/mest

$D 4 A$ en $D 4 B$ aflaten mest en volzetten met water

D4A en D4B aflaten water/mest 


\section{Bijlage 7: Procedure voor het nemen van mestmonsters tijdens aflaten}

\section{Voorbereiding}

- Check: is de centrale put achter N12 leeg?

- Check: zijn alle tussenputten leeg?

- Check: is niemand anders mest aan het pompen (zuiver mestmonster van proefafdeling)?

- Zet de kleppen bij de biogas en de afsluiter bij de put open zodat de mest die je gaat aflaten direct door kan stromen.

- Zet 2 gelabelde (afdelingsnummer, datum en inhoud) monsterpotten van 1 liter, een schep en twee opvangemmers klaar bij de centrale put.

- Trek eerst de afsluiters van de beide mestkanalen open van de afdeling die je wilt bemonsteren. Deze mest wordt bemonsterd zoals hieronder aangegeven.

- Trek vervolgens de afsluiters van de beide waterkanalen open van dezelfde afdeling. Deze waterige mest wordt bemonsterd zoals hieronder aangegeven.

\section{Procedure per afdeling}

\section{Mestkanaal}

- Schep continu monsters van de uitstromende mest en voeg deze toe aan de emmer.

- Meng de mest in de emmer, zonder er lucht in te slaan.

- De pH van het monster in de emmer wordt direct gemeten.

- Van het monster in de emmer worden 2 sub-monsters genomen van ca. $1 \mathrm{~L}$ in goed af te sluiten monsterpotten. De monsterpotten zijn gecodeerd met afdelingsnummer, datum, bestemming, inhoud (mestkanaal). Het ene monster is bedoeld voor lab-analyses in Wageningen, het andere monster is bedoeld voor onderzoek naar de $\mathrm{pH}$ gradiënt bij de Uni van Z. Denemarken.

- Uit de emmer worden tevens twee sub-monsters genomen in, vooraf gewogen, luchtdichte potjes van $60 \mathrm{ml}$. Deze potjes worden voor $1 / 4$ deel gevuld met mest (geen lucht in het monster slaan!) met een schepje. De monsterpotjes zijn in het lab reeds gecodeerd met een nummer. Op een invulformulier wordt achter het nummer het volgende aangegeven: afdelingsnummer, datum, inhoud en volgnummers 1,2 . De mest in het ene monsterpotje wordt in Denemarken geanalyseerd op totaal anorganisch koolstof (TIC) en de mest in het andere monsterpotje op alkaliniteit.

- $\quad$ Giet de emmer leeg en spoel deze schoon. Zorg er voor dat er geen water achterblijft in de emmer voor de volgende monstername.

\section{Waterkanaal}

- Schep continu monsters van het uitstromende water en voeg deze toe aan de emmer.

- Meng de mest in de emmer, zonder er lucht in te slaan.

- $\quad$ De pH van het monster in de emmer wordt direct gemeten.

- Van het monster in de emmer wordt 1 sub-monster genomen van ca. $1 \mathrm{~L}$ in goed af te sluiten monsterpotten. De monsterpot is gecodeerd met afdelingsnummer, datum, bestemming, inhoud (waterkanaal).

Alle monsters worden opgeslagen bij $-20^{\circ} \mathrm{C}$ tot de uitvoering van de analyse en het onderzoek.

\section{Na afloop}

- $\quad$ Spuit alle materialen schoon met de brandslang.

- Als alle mest uit de afdeling is afgelaten, maak de afsluiters van de mestkanalen weer dicht.

- Wacht tot er geen mest meer in de centrale put achter N12 stroomt.

- Pas dan kun je de procedure herhalen voor de volgende proefafdeling.

Dit doe je voor elke afdeling die je wilt bemonsteren. 


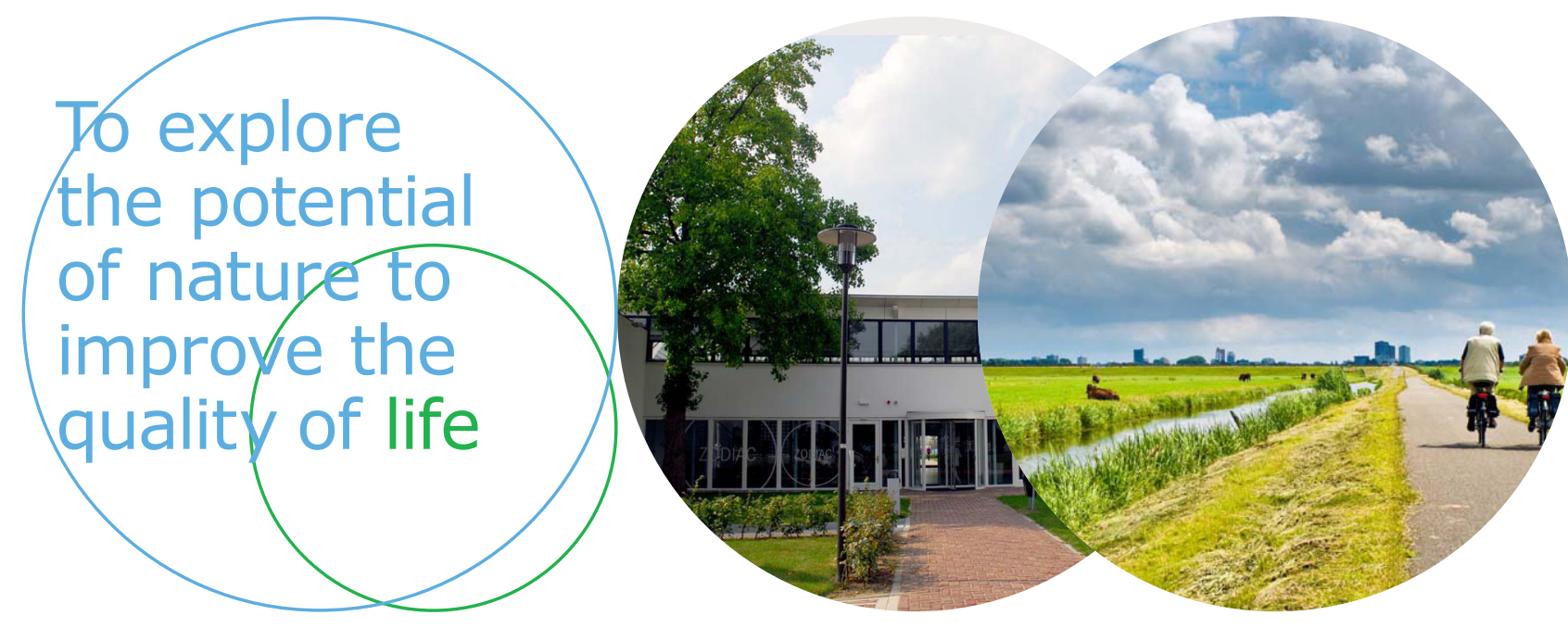

Wageningen Livestock Research Postbus 338

Wageningen Livestock Research ontwikkelt kennis voor een zorgvuldige en 6700 AH Wageningen

T 0317483953

E info.livestockresearch@wur.nl www.wur.nl/ livestock-research renderende veehouderij, vertaalt deze naar praktijkgerichte oplossingen en innovaties, en zorgt voor doorstroming van deze kennis. Onze wetenschappelijke kennis op het gebied van veehouderijsystemen en van voeding, genetica, welzijn en milieu-impact van landbouwhuisdieren integreren we, samen met onze klanten, tot veehouderijconcepten voor de $21 \mathrm{e}$ eeuw.

De missie van Wageningen University \& Research is 'To explore the potential of nature to improve the quality of life'. Binnen Wageningen University \& Research bundelen 9 gespecialiseerde onderzoeksinstituten van Stichting Wageningen Research en Wageningen University hun krachten om bij te dragen aan de oplossing van belangrijke vragen in het domein van gezonde voeding en leefomgeving. Met ongeveer 30 vestigingen, 6.500 medewerkers en 10.000 studenten behoort Wageningen University \& Research wereldwijd tot de aansprekende kennisinstellingen binnen haar domein. De integrale benadering van de vraagstukken en de samenwerking tussen verschillende disciplines vormen het hart van de unieke Wageningen aanpak. 